RPP-RPT-55983, Rev. 0

\title{
241-AP Tank Farm Construction Extent of Condition Review for Tank Integrity
}

\author{
T.J. Barnes, J.R. Gunter, and G.E. Reeploeg \\ Washington River Protection Solutions, LLC \\ Richland, WA 99352 \\ U.S. Department of Energy Contract DE-AC27-08RV14800

$\begin{array}{llll}\text { EDT/ECN: } & \text { DRF } & \text { UC: N/A } & \\ \text { Cost Center: } & \text { 2KE00 } & \text { Charge Code: } 201611 \\ \text { B\&R Code: } & \text { N/A } & \text { Total Pages: } 265 \text { JDA } 4 / 4 / 14\end{array}$

Key Words: DST, 241-AP Tank Farm, leak, tank construction, extent of condition

Abstract: This report provides the results of an extent of condition construction history review for the 241-AP tank farm. The construction history of the 241-AP tank farm has been reviewed to identify issues similar to those experienced during tank AY-102 construction. Those issues and others impacting integrity are discussed based on information found in available construction records, using tank AY-102 as the comparison benchmark. In the 241-AP tank farm, the sixth double-shell tank farm constructed, tank bottom flatness, refractory material quality, post-weld stress relieving, and primary tank bottom weld rejection were improved.

TRADEMARK DISCLAIMER. Reference herein to any specific commercial product, process, or service by trade name, trademark, manufacturer, or otherwise, does not necessarily constitute or imply its endorsement, recommendation, or favoring by the United States Government or any agency thereof or its contractors or subcontractors.

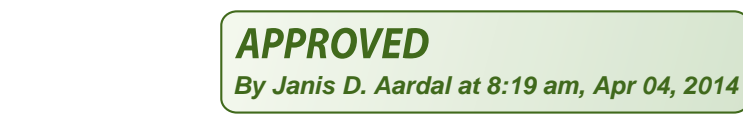

Release Approval
By Janis D. Aardal at 8:19 am, Apr 04, 2014

Date

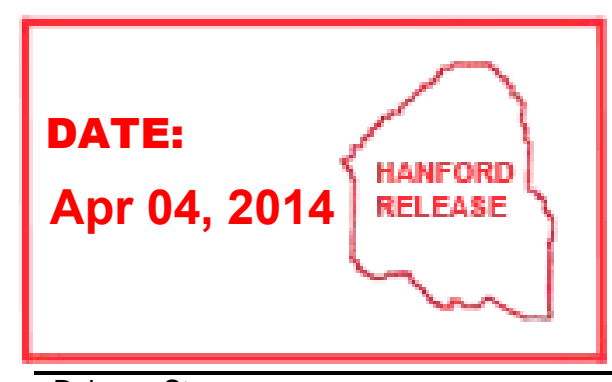

Release Stamp

Approved For Public Release 
RPP-RPT-55983

Revision 0

\section{1-AP Tank Farm Construction Extent of Condition Review for Tank Integrity}

T. J. Barnes

J. R. Gunter

G. E. Reeploeg

Washington River Protection Solutions, LLC

Date Published

March 2014

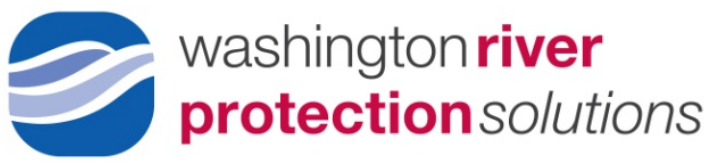

Prepared for the U.S. Department of Energy

Office of River Protection

Contract No. DE-AC27-08RV14800 
RPP-RPT-55983, Rev. 0

\section{EXECUTIVE SUMMARY}

The construction of the 241-AP tank farm has been reviewed to identify any concerns for the long-term integrity of the tanks. This initial review was prompted by construction issues identified during the formal leak assessment for tank 241-AY-102 (AY-102), RPP-ASMT53793, Tank 241-AY-102 Leak Assessment Report. In tank AY-102, bulges in the secondary liner, deterioration of refractory during post-weld stress relieving (post-weld heat treatment), and primary tank floor plate welding rework during construction left residual stresses in the tank that may have accelerated corrosion and contributed to the primary tank failure. The main purpose of this review was to determine whether the construction methods utilized after completion of the 241-AY tank farm either improved the quality and integrity of the sixth double-shell tank farm built (241-AP tank farm) or produced similar reduced margins.

The secondary liner bottom thickness was increased from 1/4-in. in the 241-AY tank farm to 3/8 in. in the 241-AP tank farm and the primary tank bottom thickness was increased from 3/8-in. to 1/2-in. The American Society for Testing and Materials (ASTM) A537-79 carbon steel plate material utilized in the 241-AP tank farm also varied from the ASTM A515-65 carbon steel plate used in the 241-AY tank farm. ASTM A537 provides a higher yield strength.

During construction of the 241-AP tank farm, primary tank bottom weld rejection was significantly improved over that seen during 241-AY-102 tank construction. A weld rejection of $5 \%$ to $12 \%$ was noted in the 241 -AP tank farm, while tank AY-102 primary bottom saw a 34\% weld rejection. There were two out-of-specification bulges in primary tank AP-104. Dead weight was placed on the bulges, which brought the primary bottom into specification. No bulges were found in any of the secondary liner bottoms. All 241-AP tank farm stress relief processes were completed successfully using alternate code requirements $\left(1000^{\circ} \mathrm{F}\right.$ for three hours per inch or $950^{\circ} \mathrm{F}$ for 5 hours for AP-108 only) and were accepted. There is a higher certainty of proper stress relief in the 241-AP tank farm than was noted for tank AY-102.

Litecrete 60M was the castable refractory material utilized in the 241-AP tank farm tanks (RPP19097, Evaluation of Insulating Concrete in Hanford Double-Shell Tanks, incorrectly indicates that Lite Wate 70 castable refractory material was used). For tanks AP-101 through AP-107, no indication of out-of-specification refractory was found. Plastic shrinkage cracks were found in tank AP-108 refractory, caused by curing too quickly. These cracks were filled with refractory material and the refractory was accepted.

Tank bottom bulging, refractory material quality, post-weld stress relieving, and primary tank bottom weld rejection in the 241-AP tank farm were improved when compared to tank AY-102. These issues, along with others (e.g. concrete foundation and encasement repairs and weld joint preparation), are judged to be minor. Overall condition of the 241-AP tank farm following construction is judged to be better than that of tank AY-102. 


\section{TABLE OF CONTENTS}

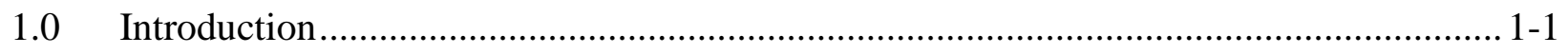

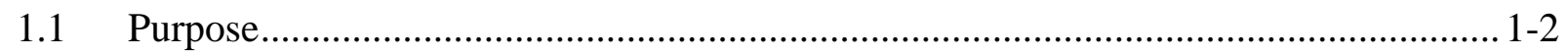

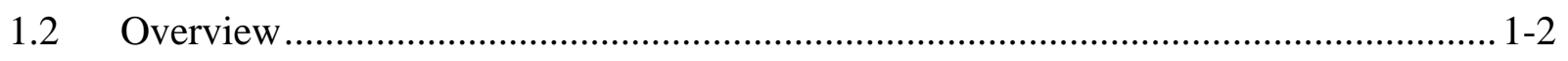

1.3 Double-Shell Tank Description ..................................................................... 1-2

2.0 241-AP Tank Farm Construction Information....................................................... 2-1

3.0 Materials of Construction ................................................................................ 3-1

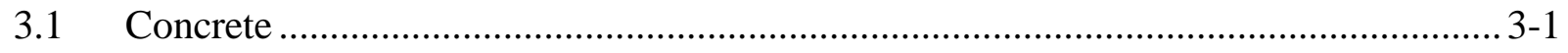

3.2 Reinforcing Bar.......................................................................................

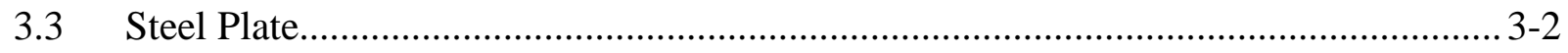

3.3.1 Secondary Plate....................................................................................

3.3.2 Primary Plate .................................................................................... $3-2$

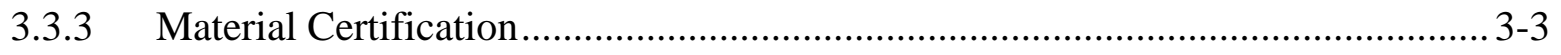

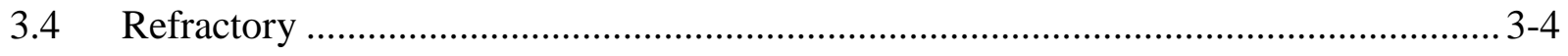

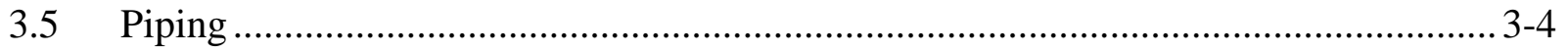

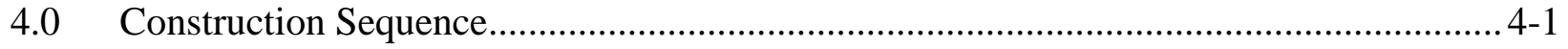

4.1 Concrete Foundation ......................................................................................... $4-2$

4.2 Secondary Liner Bottom ..................................................................................... 4-3

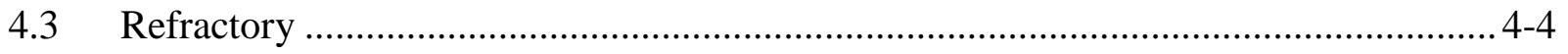

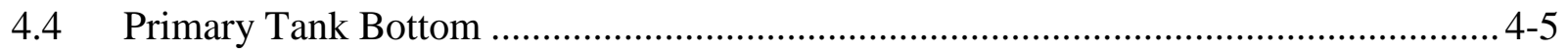

4.5 Primary Tank Wall and Tank Dome .................................................................. 4-6

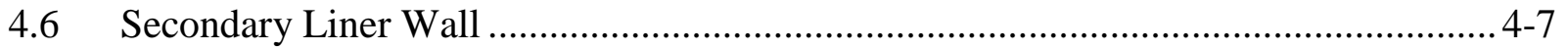

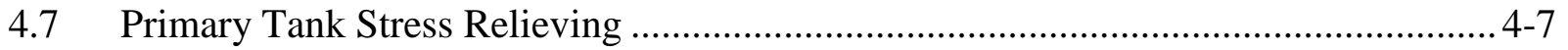

4.8 Primary Tank Hydrostatic Test ............................................................................ 4-9

4.9 Complete Secondary Liner Wall and Tank Penetrations ...................................... 4-10

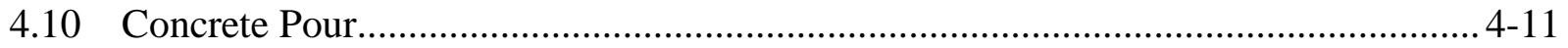

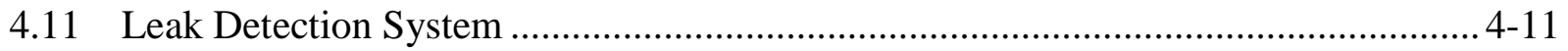

4.12 Tank Appurtenances .................................................................................... 4-12

4.13 Post-Construction Riser Installation ................................................................. 4-12

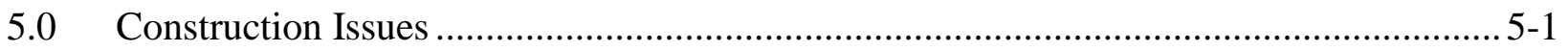

$5.1 \quad$ Welding and Non-Destructive Examination......................................................... 5-1

5.1.1 Non-Destructive Examination Methods Utilized............................................. 5-1

5.1.2 Primary Tank Bottom Weld Film Rejection Rates ...........................................5-2

5.1.3 Welding Related Nonconformance Reports ................................................. 5-5 
$5.2 \quad$ Post-Weld Stress Relieving............................................................................. 5-11

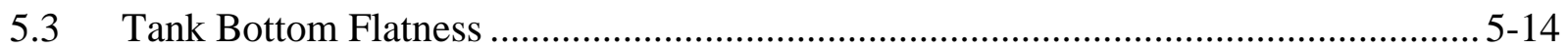

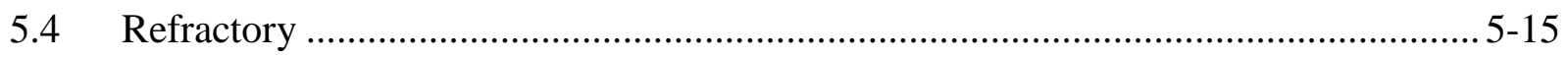

5.5 Issues Unique to 241-AP Tank Farm................................................................... 5-16

5.5.1 Steel Plate Damages..................................................................................... 5-16

5.5.2 Tank Dome Distortions ................................................................................... 5-17

5.5.3 Tank Foundation ..................................................................................... 5-17

5.5.4 Tank Concrete Shell................................................................................. 5-25

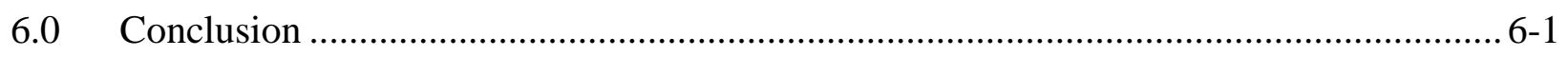

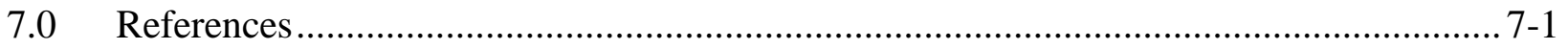

\section{TABLE OF APPENDICES}

Appendix A Supporting Documentation …………….............................................. A-1

Appendix B Tank Deficiency Documentation ……………………….............................. B-1

\section{LIST OF FIGURES}

Figure 1-1. Double-Shell Tank Construction......................................................................... 1-3

Figure 3-1. Primary Tank Wall Configuration and Thickness ................................................ 3-3

Figure 4-1. Concrete Foundation Placement (Photo 108941-8cn) (Taken 8/9/1983) .................. 4-2

Figure 4-2. 241-AY Leak Detection Design ............................................................................... 4-2

Figure 4-3. 241-AP Foundation Leak Detection System Design ................................................ 4-3

Figure 4-4. Fabrication of Secondary Liner Bottom. (Photo 110871-1) (Tank 12/28/1983) ...... 4-3

Figure 4-5. Fabrication of Secondary Liner Bottom. (Photo 110871-3)

(Taken 12/28/1983)...................................................................................................... 4-3

Figure 4-6. Transporting a Secondary Liner Bottom from Cribbing to Foundation (Photo 8400302-36cn) (Taken 1/4/1984).......................................................................... 4-4

Figure 4-7. Refractory Placement (Photo 8401213-32cn) (Taken 2/24/1984) .............................. 4-4

Figure 4-8. Refractory Air Distribution Slot Forming (Photo 8402704-14cn) (Taken

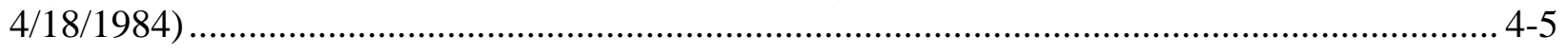

Figure 4-9. Primary Tank Bottom Erection (Photo 8402306-5cn) (Taken 3/28/1984) ................ 4-5

Figure 4-10. Primary Tank Dome Erection (Photo 8405415-34cn) (Taken 8/1/1984) ................ 4-6

Figure 4-11. Lifting of the Primary Tank Dome (Photo 8405145-67cn) (Taken 8/1/1984)........ 4-6

Figure 4-12. Lifting Primary Tank Dome (Photo 8405415-85cn) (Taken 8/1/1984)................... 4-6

Figure 4-13. Secondary Liner Wall Erection (Photo 8405415-37cn) (Taken 8/1/1984) .............. 4-7 
RPP-RPT-55983, Rev. 0

Figure 4-14. Insulation for Post-Weld Stress Relief of Tank AP-102 (Photo 8405415-2cn) (Taken 8/1/1984) .................................................................................................... 4-7

Figure 4-15. 241-AP Post Weld Stress Relief Burner Layout ................................................. 4-8

Figure 4-16. Equipment for Hydrostatic Test Water Fill on Tank AP-108 (Photo 8407495-2cn) (Taken 10/1/1984) ................................................................................. 4-9

Figure 4-17. Secondary Liner and Penetration Completion (Photo 8405795-1cn) (Taken 9/10/1984) 4-11

Figure 4-18. Concrete Dome Pour on Tank AP-101 (Photo 8407523-9cn) (Taken $11 / 30 / 1984)$ 4-11

Figure 5-1. NCR B-340-33 Joint Preparation Evidence ..................................................... 5-8

Figure 5-2. NCR B-340-58 Joint Preparation Evidence (1/2) .............................................. 5-9

Figure 5-3. NCR B-340-58 Joint Preparation Evidence (2/2) ............................................ 5-10

\section{LIST OF APPENDIX FIGURES}

App. Figure A-1. Refractory Certificate of Compliance .................................................... A-2

App. Figure A-2. 107-AP Riser/Pit Installation Scope and Status Update.............................. A-5

App. Figure A-3. 107-AP Post-Construction Riser Installation Stress Relief Discussion ......... A-7

App. Figure A-4. Project W-E01 Completion ............................................................... A-17

App. Figure A-5. Project W-E01 Concrete Demolition Demonstration................................. A-18

App. Figure B-1. Nonconformance Report B-340-33 …........................................................2

App. Figure B-2. Nonconformance Report B-340-34 ........................................................

App. Figure B-3. Nonconformance Report B-340-58 ….....................................................6

App. Figure B-4. Nonconformance Report B-340-61 .........................................................9

App. Figure B-5. Nonconformance Report B-340-62 ......................................................

App. Figure B-6. Nonconformance Report B-340-63 ...................................................... B-11

App. Figure B-7. Nonconformance Report B-340-66 .........................................................

App. Figure B-8. Nonconformance Report B-340-70 .....................................................13

App. Figure B-9. Memorandum Regarding Welding Surface Preparation ............................B-14

App. Figure B-10. Nonconformance Report B-340-76 ..................................................... -15

App. Figure B-11. Nonconformance Report B-340-81 …..................................................-22

App. Figure B-12. Nonconformance Report B-340-88 .....................................................-26

App. Figure B-13. Nonconformance Report B-340-95 ......................................................28

App. Figure B-14. Nonconformance Report B-340-96 ......................................................32

App. Figure B-15. Nonconformance Report B-340-115 .....................................................33 
App. Figure B-16. Nonconformance Report B-340-56 ....................................................34

App. Figure B-17. Nonconformance Report B-340-85 .....................................................36

App. Figure B-18. Letter from Hogan Manufacturing to American Bridge - Plate

Laminations..

App. Figure B-19. Nonconformance Report B-340-89 ....................................................

App. Figure B-20. Nonconformance Report B-340-98 .......................................................-44

App. Figure B-21. Nonconformance Report B-340-102 …...............................................47

App. Figure B-22. Nonconformance Report B-340-105 ....................................................49

App. Figure B-23. Nonconformance Report B-340-13 ......................................................-51

App. Figure B-24. Nonconformance Report B-340-14 ......................................................

App. Figure B-25. Nonconformance Report B-340-15 ...................................................... -60

App. Figure B-26. Nonconformance Report B-340-17 ......................................................62

App. Figure B-27. Nonconformance Report B-340-21 .......................................................6-65

App. Figure B-28. Nonconformance Report B-340-23 ......................................................6-66

App. Figure B-29. Nonconformance Report B-340-24 ...................................................6-67

App. Figure B-30. Nonconformance Report B-340-29 ..................................................... -72

App. Figure B-31. Nonconformance Report B-340-30 .......................................................-75

App. Figure B-32. Nonconformance Report B-340-40 .......................................................-77

App. Figure B-33. Nonconformance Report B-340-42 ….................................................

App. Figure B-34. Nonconformance Report B-340-43 ..................................................... -80

App. Figure B-35. Nonconformance Report B-340-46 ......................................................B-82

App. Figure B-36. Nonconformance Report B-340-47 .......................................................8-85

App. Figure B-37. Nonconformance Report B-340-49 .......................................................8-89

App. Figure B-38. Nonconformance Report B-340-51 .....................................................92

App. Figure B-39. Nonconformance Report B-340-53 .......................................................94

App. Figure B-40. Nonconformance Report B-340-101 …..................................................95

App. Figure B-41. Nonconformance Report B-340-107 ....................................................-98

App. Figure B-42. Nonconformance Report B-340-108 ...................................................

App. Figure B-43. Nonconformance Report B-340-109 .....................................................-102

App. Figure B-44. Nonconformance Report B-340-111 …..............................................

App. Figure B-45. Nonconformance Report B-340-114 ...................................................-106

App. Figure B-46. Nonconformance Report B-340-116 ................................................

App. Figure B-47. Nonconformance Report B-340-117 ................................................... 
App. Figure B-48. Nonconformance Report B-340-118 …................................................112

App. Figure B-49. Nonconformance Report B-340-120 ................................................ -113

App. Figure B-50. Nonconformance Report B-340-121 …................................................-115

App. Figure B-51. Nonconformance Report B-340-124 …...............................................-118

App. Figure B-52. Nonconformance Report B-340-125 .................................................. -131

App. Figure B-53. Nonconformance Report B-340-126 ...................................................-133

App. Figure B-54. Nonconformance Report B-340-127 ................................................... -135

App. Figure B-55. Nonconformance Report B-340-129 ................................................ -148

App. Figure B-56. Nonconformance Report B-340-130 ...................................................-161

App. Figure B-57. Nonconformance Report B-340-132 .................................................. -164

App. Figure B-58. Nonconformance Report B-340-134 .................................................. 167

\section{LIST OF TABLES}

Table 1-1. Double-Shell Construction and Age as of 2014 ............................................... 1-2

Table 1-2. Letter Designations for 241-AP Tank Farm ...................................................... 1-2

Table 3-1. Materials Comparison .................................................................................... 3-1

Table 4-1. Post-Weld Stress Relieving in the 241-AP Farm ................................................ 4-9

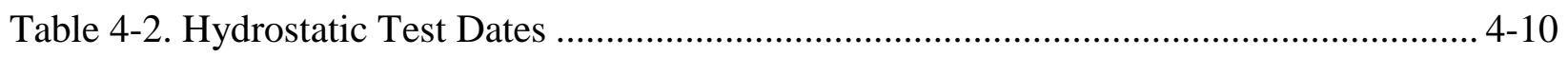

Table 5-1. 241-AP Tank Farm Non-Destructive Examinations Used During Construction ....... 5-1

Table 5-2. 241-AP Tank Farm Primary Tank Bottom Weld Rejection Rate Summary ............. 5-2

Table 5-3. Tanks AP-101 and AP-102 Primary Bottom Welding Success Comparison............. 5-3

Table 5-4. Tanks AP-103 and AP-104 Primary Bottom Welding Success Comparison............. 5-3

Table 5-5. Tanks AP-105 and AP-106 Primary Bottom Welding Success Comparison............ 5-4

Table 5-6. Tanks AP-107 and AP-108 Primary Bottom Welding Success Comparison............. 5-4

Table 5-7. 241-AY Tank Farm Primary Tank Bottom Welding Success Comparison ............... 5-5

Table 5-8. Nonconformance Reports Related to Welding Quality......................................... 5-6

Table 5-9. Post-Weld Stress Relieving Nonconformance Reports ....................................... 5-11

Table 5-10. Tank Foundation Nonconformance Reports ................................................... 5-18

Table 5-11. Concrete Shell Nonconformance Reports ....................................................... 5-25

Table 6-1. Summary Comparison 241-AP Tank Farm Construction to Tank AY-102 .............. 6-3 
RPP-RPT-55983, Rev. 0

\section{LIST OF TERMS}

\section{Abbreviations and Acronyms}

ASME

ASTM

BNS

BRS

DOE

DST

ECN

LDP

NCR

NDE

Rockwell

RRS

SMAW

TOC

WRPS

WST

\section{Units}

$\begin{array}{ll}\mathrm{ft} & \text { Feet } \\ \text { in } & \text { Inch } \\ \mathrm{h} & \text { Hour } \\ \mathrm{lb} & \text { Pound } \\ \text { Mgal } & \text { Million Gallons }\end{array}$

American Society of Mechanical Engineers

American Society for Testing and Materials

Bottom North-South weld seam

Bottom Round Seam

U.S. Department of Energy

Double-Shell Tank

Engineering Change Notice

Leak Detection Pit

Non-Conformance Report

Non-Destructive Examination

Rockwell Hanford Operations

Roof Round Seam (tank dome)

Shielded Metal Arc Welding

Tank Operations Contractor

Washington River Protections Solutions LLC

Waste Storage Tank

\section{TRADEMARK DISCLOSURE}

ASME is a registered trademark of American Society of Mechanical Engineers ASTM is a registered trademark of American Society for Testing and Materials

Kaolite is a registered trademark of Babcock \& Wilcox Company 
RPP-RPT-55983, Rev. 0

\subsection{INTRODUCTION}

This document provides an overview of construction, noting any difficulties encountered for the 241-AP tank farm, the sixth double-shell tank (DST) farm constructed. In October 2012, it was determined that the primary tank of DST 241-AY-102 (AY-102) was leaking (RPP-ASMT53793, Rev. 0, Tank 241-AY-102 Leak Assessment Report). In tank AY-102, bulges in the secondary liner, deterioration of refractory during post-weld stress relieving, and primary tank floor plate welding rework during construction compromised the intended robustness and corrosion resistance of the tank design and probably contributed to the primary tank's failure.

Following identification of the tank AY-102 probable leak cause, an Extent of Condition (EOC) evaluation was prepared using U.S. Department of Energy’s Energy Facilities Contractors Group (EFCOG) Guidance for Extent of Conditions Evaluations. The EFCOG process was used to identify other DSTs with construction, waste storage, or thermal histories similar to that of tank AY-102 (Interoffice MemorandumWRPS-1204931, Double-Shell Tank 241-AY-102 Primary Tank Leak Extent of Condition Evaluation and Recommended Annulus Visual Inspection Intervals). The EOC evaluation identified six tanks with similar construction and operating histories for additional evaluation which included: 241-AY-101, 241-AZ-101, 241-AZ-102, 241-SY-101, 241-SY-102, and 241-SY-103.

One evaluation was to identify any similarities in construction that could be a precursor for accelerated corrosion and premature failure. Analysis of these tanks was considered to be the first phase and was documented in the following reports:

- RPP-RPT-54817, 241-AY-101 Tank Construction Extent of Condition Review for Tank Integrity

- RPP-RPT-54818, 241-AZ Tank Farm Construction Extent of Condition Review for Tank Integrity

- $\quad$ RPP-RPT-54819, 241-SY Tank Farm Construction Extent of Condition Review for Tank Integrity

Upon completion of the first phase of construction history review, a recommendation to proceed with reviews of the 241-AW, 241-AN, and 241-AP tank farms was provided in external letter WRPS-1302595, Washington River Protection Solutions LLC Submittal of Recommended Modifications to Double-Shell Tank Visual Inspections. Phase two of the DST Construction extent of condition review includes the twenty-one tanks contained in the 241-AW, 241-AN, and 241-AP tank farms. 241-AW and 241-AN tank farms were evaluated in the following reports:

- $\quad$ RPP-RPT-55981, 241-AW Tank Farm Construction Extent of Condition Review for Tank Integrity

- RPP-RPT-55982, 241-AN Tank Farm Construction Extent of Condition Review for Tank Integrity

This report is the last of the six extent-of-condition reports for the Hanford DSTs. 


\subsection{PURPOSE}

The construction of the 241-AP tank farm has been reviewed to identify issues similar to those experienced during tank AY-102 construction. In this document, those issues and others impacting integrity are discussed based on information found in available construction records, using tank AY-102 as the comparison benchmark.

\subsection{OVERVIEW}

Six double-shell tank (DST) farms were constructed over a period of roughly 18 years (from 1968 to 1986), with a design life of 20 to 50 years. The 241-AP tank farm was the sixth farm to be constructed and is the focus of this report. Table 1-1 provides the construction dates, year of initial service, and the expected service life for the DSTs.

Table 1-1. Double-Shell Construction and Age as of 2014

\begin{tabular}{|c|c|c|c|c|c|c|}
\hline Tank Farm & $\begin{array}{c}\text { Number of } \\
\text { Tanks }\end{array}$ & $\begin{array}{c}\text { Construction } \\
\text { Period }\end{array}$ & $\begin{array}{c}\text { Construction } \\
\text { Project }\end{array}$ & $\begin{array}{c}\text { Initial } \\
\text { Operation }\end{array}$ & $\begin{array}{c}\text { Service } \\
\text { Life }\end{array}$ & Current Age \\
\hline $241-A Y$ & 2 & $1968-1970$ & IAP-614 & 1971 & 40 & 43 \\
\hline $241-A Z$ & 2 & $1970-1974$ & HAP-647 & 1976 & 20 & 38 \\
\hline $241-S Y$ & 3 & $1974-1977$ & B-101 & 1977 & 50 & 37 \\
\hline $241-A W$ & 6 & $1976-1979$ & B-120 & 1980 & 50 & 34 \\
\hline $241-A N$ & 7 & $1977-1980$ & B-130, B-170 & 1981 & 50 & 33 \\
\hline $241-A P$ & 8 & $1982-1986$ & B-340 & 1986 & 50 & 28 \\
\hline Total & 28 & & & & & \\
\hline
\end{tabular}

In the construction records, letter designations A through $\mathrm{P}$ were often used to identify each primary tank or secondary liner. Table 1-2 provides a legend for these letter designations.

\subsection{DOUBLE-SHELL TANK DESCRIPTION}

Each DST consists of a primary carbon steel tank inside of a secondary carbon steel liner, which is surrounded by a reinforced concrete shell. The primary steel tank rests atop an 8-in. insulating concrete slab, separating it from the secondary steel liner, and providing for air circulation/leak detection channels under the primary tank bottom plate. An annular space of 2-1/2 ft. exists between the secondary liners and primary tanks, allowing for visual examination of the tank wall and secondary liner annular surfaces. The annular space also allows for ultrasonic volumetric inspections of the primary tank walls and secondary liners.
Table 1-2. Letter Designations for 241-AP Tank Farm

\begin{tabular}{|c|c|c|}
\hline Tank & Primary & Secondary \\
\hline AP-101 & M & E \\
\hline AP-102 & K & D \\
\hline AP-103 & O & H \\
\hline AP-104 & N & G \\
\hline AP-105 & P & B \\
\hline AP-106 & L & A \\
\hline AP-107 & J & F \\
\hline AP-108 & I & C \\
\hline
\end{tabular}




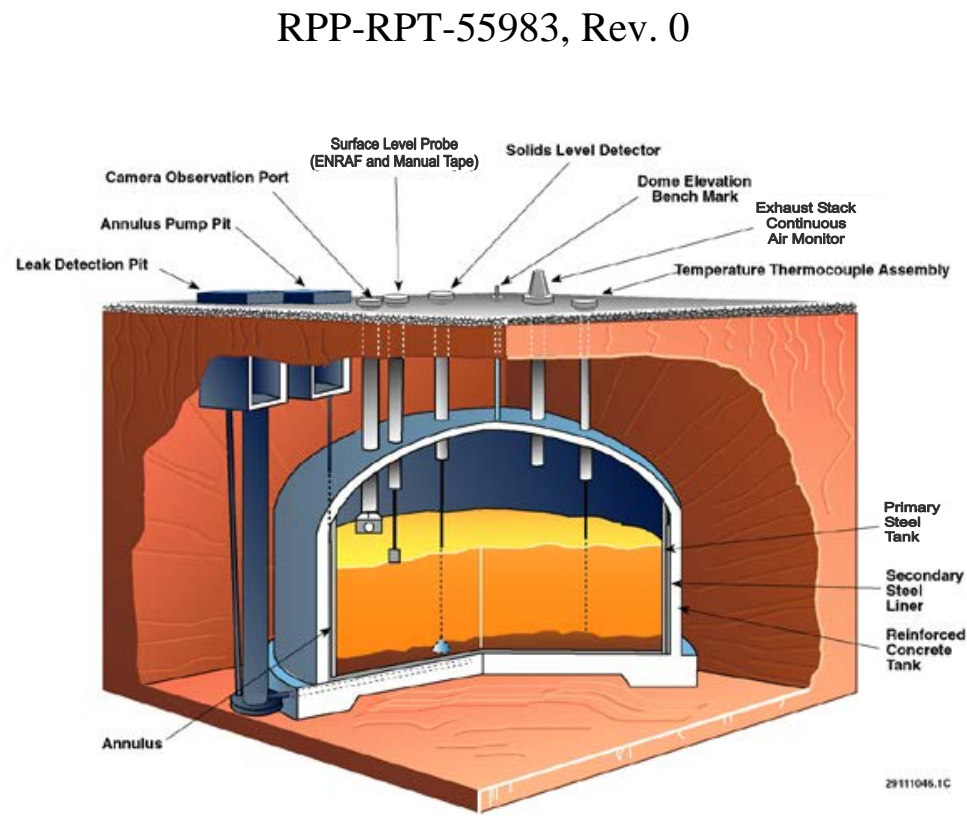

Figure 1-1. Double-Shell Tank Construction

Each tank in the 241-AP tank farm has 71 risers penetrating the dome, providing access for video cameras, ultrasonic inspection devices, waste sampling devices, mixer pumps, and other equipment requiring access to either the primary tank interior or annular space 
RPP-RPT-55983, Rev. 0

\section{$2.0 \quad$ 241-AP TANK FARM CONSTRUCTION INFORMATION}

The 241-AP tank farm was constructed between 1982 and 1986. It was designated as Project B-340, 241-AP Tank Farm. Rockwell Hanford Operations (Rockwell) built the tank farm for the United States Department of Energy (DOE). The 241-AP tank farm contains eight tanks and ancillary equipment. American Bridge Division of US Steel Corporation (American Bridge) was contracted to build the farm. Construction management was provided by J.A. Jones.

The 241-AP tank farm was built according to SD-340-FDC-001, Function Design Criteria, and the following construction specifications:

- B-340-D1, Design Specification for Primary and Secondary Steel Tanks 241-AP Tank Farm

- B-340-C1, Construction Specification for the 241-AP Tank Farm Site Preparation

- B-340-C2, Construction Specification for the 241-AP Tank Farm Site Excavation

- B-340-C3, Construction Specification for the 241-AP Tank Farm Tank Foundations

- B-340-C4, Construction Specification for Primary and Secondary Steel Tanks 241-AP Tank Farm

- B-340-C5, Construction Specification for the 241-AP Tank Farm Tank Encasement

- B-340-C6, Construction Specification for the 241-AP Tank Farm Backfill

- B-340-C7, Construction Specification for the 241-AP Tank Farm Completion

The following three specifications were added to support additional project scope:

- B-340-C8, Construction Specification for the 241-AP Tank Farm - 242A Evaporator Modifications

- B-340-C9, Construction Specification for 241-AP Tank Farm Cathodic Protection Systems

- B-340-C10, Construction Specification for 241-AP Tank Farm Additional Pipe Line

To obtain information about the construction history, the Record Holding Area (RHA) and Integrated Data Management System (IDMS) were queried for boxes containing files from Project B-340. This information includes:

1. Inspection Reports

2. Radiographic Test Reports

3. Materials Certifications

4. Non-conformance reports

5. Project reports, correspondence, and meeting minutes

There is no evidence of daily logbook entries for construction of the 241-AP tank farm. Daily logbooks generally describe key construction events and issues; without the daily logbooks, some sections may lack extensive detail. The following sections provide an aggregation of the information collected, highlighting important events and information relevant to leak integrity. The resulting quality of construction and any issues or difficulties noted are discussed in this document. 


\subsection{MATERIALS OF CONSTRUCTION}

The materials of construction evolved from the construction of 241-AY tank farm to the construction of the 241-AP tank farm. The primary change in material selection was to use American Society for Testing and Materials (ASTM ${ }^{1}$ ) A537-79, Pressure Vessel Plates, Heat Treated, Carbon-Manganese-Silicon (Specification B-340-C4), for construction of the primary and secondary liners instead of ASTM A515, Pressure Vessel Plates, Carbon Steel, for Intermediate and Higher Temperature Service, Grade 60, used in the 241-AY tank farm.

In the 241-AP tank farm, the thickness of the secondary liner bottom plate is increased to 3/8-in. from 1/4-in. seen in the 241-AY tank farm. The primary tank bottom was increased from 3/8-in. to $1 / 2$-in. sections. The refractory material was changed from Kaolite ${ }^{2} 2200 \mathrm{LI}$ castable refractory to Litecrete $60 \mathrm{M}$ castable refractory. In addition, the refractory pour pattern was modified. Table 3-1 provides a comparison of the construction materials used in the 241-AY and 241-AP tank farms.

Table 3-1. Materials Comparison

\begin{tabular}{|l|c|c|}
\hline \multicolumn{1}{|c|}{ Material } & 241-AY Tank Farm & 241-AP Tank Farm \\
\hline Concrete & $\begin{array}{c}\text { 3000 psi } \\
\text { Type V for the walls Type III } \\
\text { for the haunch and dome }\end{array}$ & $\begin{array}{c}\text { 4500 psi Type II for the } \\
\text { foundations }\end{array}$ \\
\hline Reinforcing Bar & $\begin{array}{c}\text { ASTM A432 for the walls, } \\
\text { psi Type II for the walls, } \\
\text { domes, and haunches }\end{array}$ & $\begin{array}{c}\text { A615, Grade 60, except \#3 ties } \\
\text { ASTM A15 for the } \\
\text { foundation }\end{array}$ \\
\hline Steel Plate & ASTM A515-65 & ASTM A537-79, Class 1 \\
\hline Refractory & Kaolite 2200LI & Litecrete 60M \\
\hline
\end{tabular}

\subsection{CONCRETE}

The structural concrete used in the 241-AP tank farm foundation construction required a 4,500 psi, 28-day compressive strength. The structural concrete used in the 241-AP tank farm concrete shell construction required a 5,000 psi, 28-day compressive strength. The cement for all structural concrete used in 241-AP tank farm tank construction conformed to ASTM C150 Type II (Low Alkali). In the 241-AY tank farm, HWS-7791, Specification for Side Walls and Dome Nuclear Waste Storage Tank Project IAP-614 Purex Tank Expansion, specifies Type V concrete for the tank walls and Type III cement for haunch and dome portions of the tank. From ASTM C150, Standard Specification for Portland Cement, Type II cement is for general use with

\footnotetext{
${ }^{1}$ ASTM is a registered trademark of American Society for Testing and Materials.

${ }^{2}$ Kaolite is a registered trademark of Babcock \& Wilcox Company.
} 
moderate sulfate resistance and moderate heat of hydration. Type III cement is high early strength cement, and Type V cement is high sulfate resistant cement.

\subsection{REINFORCING BAR}

The tank foundation was reinforced with ASTM A615, Grade 60, specifications with minimum yield strength of 60,000 psi. \#5, \#6, \#7, \#8, and \#10 rebar was utilized to reinforce the tank foundation (see H-2-90439, Structural Concrete Tank Foundation Plan and Details, for details) while ASTM A615, Grade 60, \#6, \#7, \#8, \#9, and \#10 rebar was utilized to reinforce the concrete walls and dome sections (see H-2-90441, Structural Dome Reinforcement Plan and Detail, and H-2-90442, Structural Tank Section and Haunch Reinforcement, for details).

\subsection{STEEL PLATE}

All primary tank and secondary liner plates used in the 241-AP tank farm were manufactured to ASTM A537-79, Class 1, standard. The selection of ASTM A537 was a change from ASTM A515 used in the 241-AY tank farm. ASTM A537 is a fine grain size metal produced for moderate and lower temperature service, while ASTM A515 is a coarse grain size metal produced for moderate and higher temperature service. The smaller grain size in ASTM A537 increases the notch toughness and resistance to stress corrosion cracking over ASTM A515. The 241-AP tank farm tanks were erected using the American Society of Mechanical Engineers $\left(\mathrm{ASME}^{3}\right)$, Boiler and Pressure Vessel Code, 1980 through winter 1981 Editions and Addenda of the code.

\subsubsection{Secondary Plate}

The secondary liner plates consisted of 3/8-in., 1/2-in., and 9/16-in. sections (see H-2-90534, Tank Cross Section 241-AP Tank Farm, for details). The 1/2-in. plate was used in the transition plate from the lower knuckle to the bottom and first course of the liner. The 9/16-in. plate was used in the lower knuckle, and the 3/8-in. plate was used for the liner floor, walls and upper knuckle, an increase over the 1/4-in. plate used in the 241-AY tank farm.

\subsubsection{Primary Plate}

The primary tank bottom utilizes 15/16-in., 3/4-in., 9/16-in., and 1/2-in. carbon steel plates, except that a 4-ft. diameter by 1-in. thick carbon steel plate is located at the center of the primary tank bottom, and 7/8-in. carbon steel plate is used for the primary bottom knuckle. The primary tank wall thickness varies from 7/8-in. thick carbon steel at the bottom knuckle to 1/2-in. thick at the top transition plate. The transition plate from the lower knuckle to the tank bottom and first course is 15/16-in. thick. The first course is 3/4-in. thick, the second course is $9 / 16$-in. and the next two courses are 1/2-in. thick. The top transition plate is welded to a $1 / 2$-in. thick top knuckle (see H-2-90534, for details). The dome of the tank was constructed of 3/8-in. plate welded to the top knuckle, with exception of a 6-ft. diameter 1/2-in. thick plate used in the center of the tank domes. Figure 3-1 shows the configuration of the primary tank wall and the thickness of each course.

\footnotetext{
${ }^{3}$ ASME is a registered trademark of American Society of Mechanical Engineers
} 


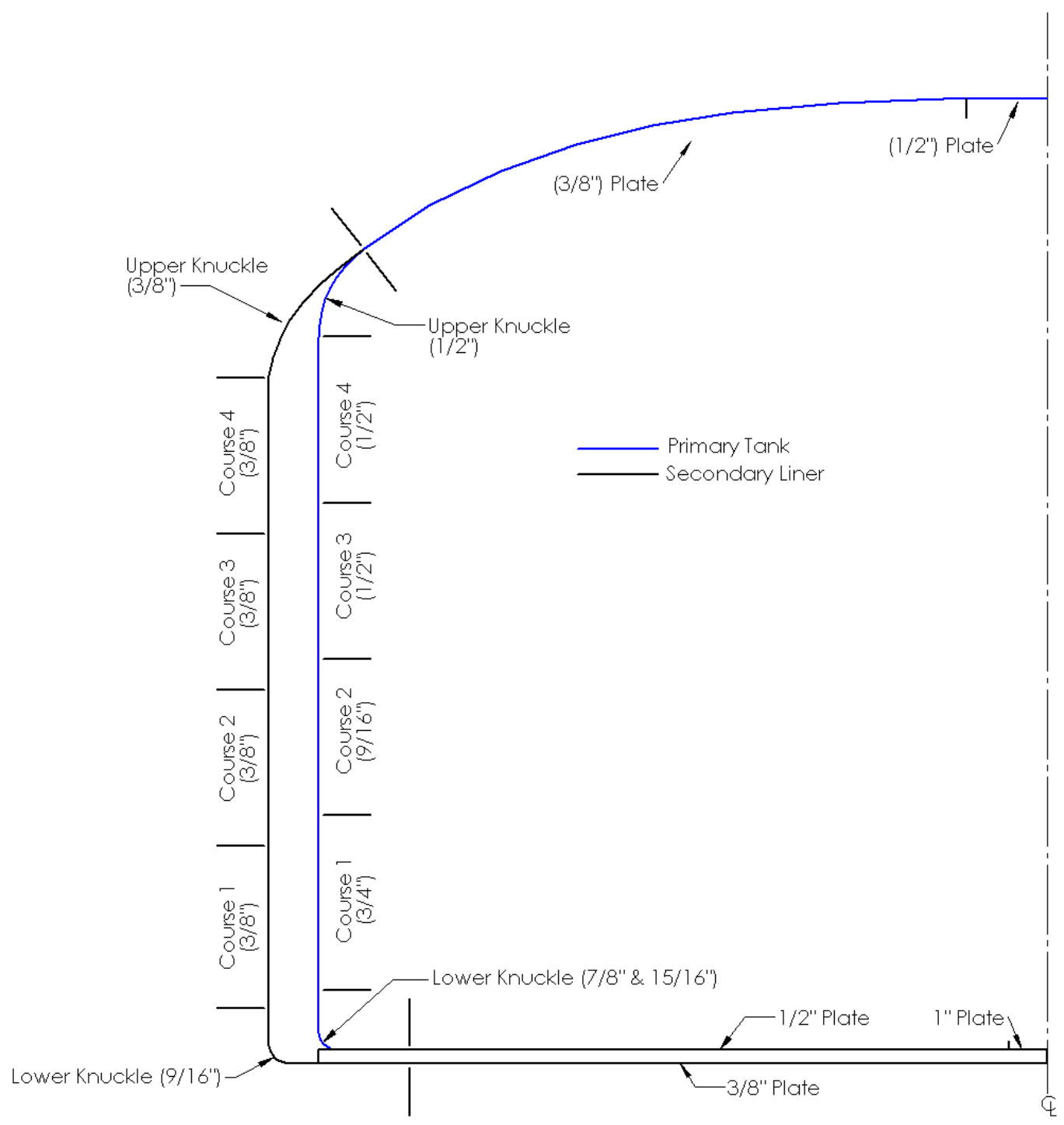

Figure 3-1. Primary Tank Wall Configuration and Thickness

\subsubsection{Material Certification}

Material certifications and chemical and physical test reports were required for each steel plate containing the heat and slab number. Material certifications contained yield strength and tensile strength information along with percent elongation for each specific heat and slab number. The chemical and physical test reports identify the percent of each element (i.e., carbon, manganese, phosphorus, etc.) contained within a sample of the material as well as properties such as, yield point, tensile strength, percent elongation, and information gathered from bend test results. 


\subsection{REFRACTORY}

Litecrete 60M was the refractory material used in the 241-AP tank farm. The refractory was required to limit the structural concrete base slab to a maximum temperature of $500^{\circ} \mathrm{F}$ during the post-weld stress relief. The material had to have an average (out of 5 test specimens) minimum compressive strength at or above 130 psi. The 241-AY tank farm used Kaolite 2200-LI castable refractory. Litecrete $60 \mathrm{M}$ was certified to comply with the physical and insulating properties specified in B-340-C4 (see App. Figure A-1).

\subsection{PIPING}

All pipe used for permanent risers was manufactured to ASTM A53 or ASTM A106 specifications. Coal tar enamel wrapped in kraft paper or coal tar tape was used on carbon steel pipe exposed to earth. 


\subsection{CONSTRUCTION SEQUENCE}

Construction of the eight 241-AP tank farm tanks was awarded to American Bridge. Excavation began in 1982 and the project was completed in 1986. J.A. Jones acted as construction management for the project.

A listing of the construction sequence follows:

1. Install reinforced structural concrete foundation for each of the eight tanks. The foundation has a tertiary leak detection system which includes a waffle grid in the structural concrete, collection pipes, and the leak detection pit.

2. When the secondary liner was fabricated over the tank foundation a plywood protective layer was installed over the tank foundation.

3. Install cribbing and jack stands for secondary liner bottom fabrication.

4. Fabricate secondary liner bottom on top of cribbing and jack stands.

5. Inspect secondary liner bottom.

6. Remove plywood and lower the secondary liner bottom onto the concrete foundation or move the liner from its construction location to its permanent location.

7. Install air distribution piping and thermocouple conduits to be embedded in the tank bottom refractory, as well as the retainer ring used as a form for the perimeter of the refractory.

8. Pour the refractory.

9. Remove forms from refractory air slots.

10. When primary tank bottoms were fabricated over the refractory, a plywood protective layer was installed on the refractory.

11. Install cribbing and jack stands for primary tank bottom fabrication.

12. Fabricate primary tank bottom on top of cribbing and jack stands.

13. Inspect primary tank bottom.

14. Lower the primary tank bottom onto the refractory or move the tank bottom from its construction location to its permanent location.

15. Weld the first, second, third, and fourth course plates, as well as the upper knuckle to the primary tank.

16. Weld the secondary liner course plates up to the last course (not including the upper knuckle).

17. Fabricate tank dome and penetrations inside the primary tank.

18. Raise tank dome into place and weld it to the primary tank upper knuckle.

19. Install insulation around the primary tank walls and dome in preparation for stress relief.

20. Conduct stress relief of the primary tank.

21. Conduct hydrostatic test of the primary tank.

22. Install upper knuckle and attach metal flashing between secondary upper knuckle and primary tank dome.

23. Install annulus penetrations.

24. Place concrete in four sections, including two vertical lifts, a haunch pour, and a dome pour.

25. Install the leak detection system, including the leak detection drain piping, sump, and well. 
26. Start backfilling the tank farm area.

27. Install appurtenances.

28. Backfill to top of the domes.

29. Install the waste transfer system of piping, pump pits, and valve pits.

30. Complete backfill.

\subsection{CONCRETE FOUNDATION}

The foundation is composed of reinforcing steel and concrete requiring a 4500 psi, 28-day compressive strength (see drawing H-2-90439, Structural Concrete Tank Foundation Plan and Details, and B-340-C3, Construction Specification for the 241-AP Tank Farm Tank Foundations, for details).

The structural reinforced concrete foundations are 89-ft. 6-in. in diameter. The foundation is 2ft. 8-in. thick from foundation center to a diameter of $81-\mathrm{ft}$. The foundation is $2-\mathrm{ft}$. thick from a diameter of 81-ft. to the edge of the foundation. The drop in foundation thickness from 2-ft. 8-in. thick to 2-ft., creates an 8-in. thick shoulder, seen in Figure 4-1. The purpose

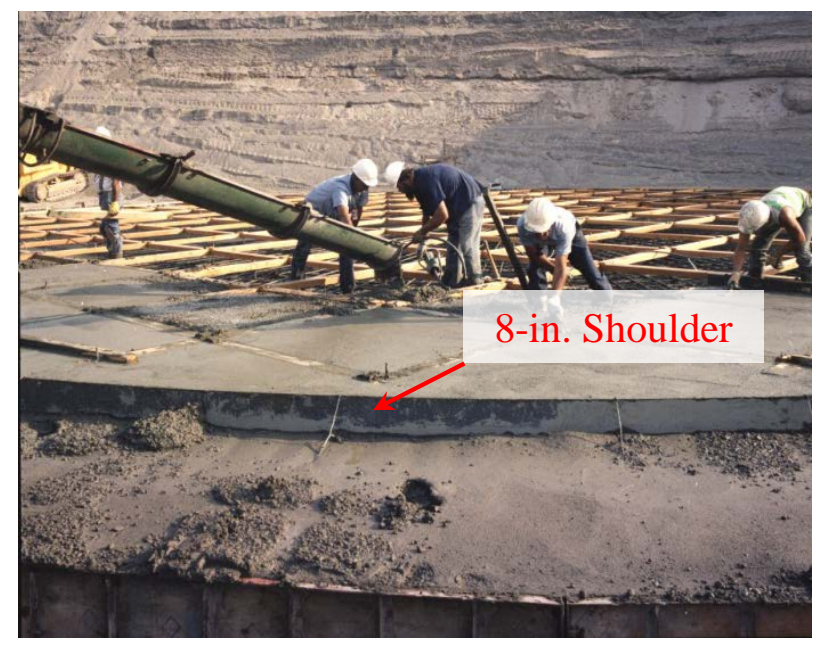

Figure 4-1. Concrete Foundation Placement (Photo 108941-8cn) (Taken 8/9/1983) of the shoulder was to resist inward lateral displacement of the concrete wall due to external forces (e.g. soil pressure).

Two rebar mats were installed, followed by instrumentation conduit. Concrete forms were then installed, including those for drain slots in the top of the foundation. The concrete was then placed and set. Following the concrete cure, forms were removed and high spots on the foundation were ground down.

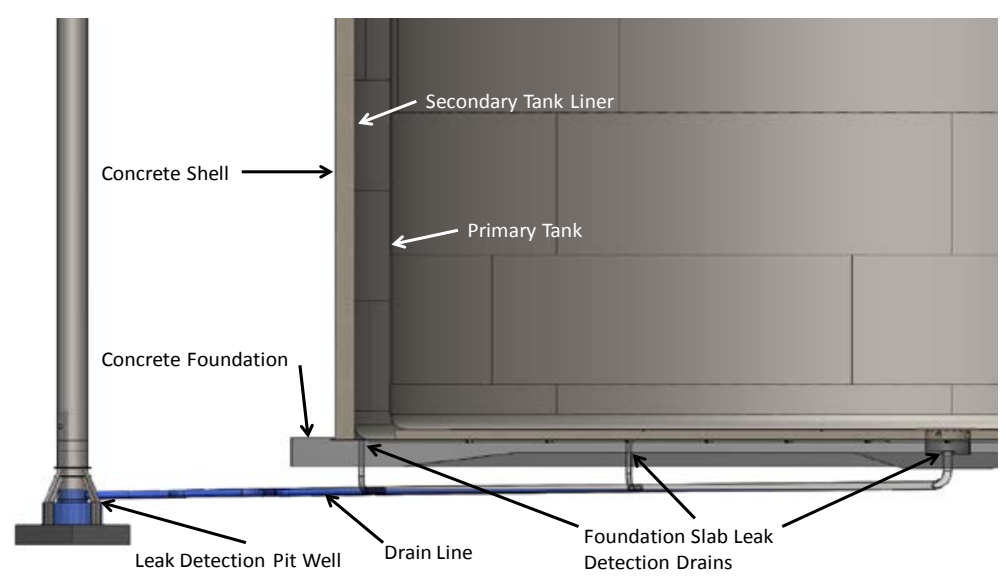

Figure 4-2. 241-AY Leak Detection Design

Structural reinforced foundations for all tanks in the 241-AP tank farm contain drain slots to direct any liquid to the leak detection drain slot. This leak detection drain slot is a change from the configuration seen in the 241-AY tank farm construction. In the 241-AY tank farm, a drain pipe was used to drain the foundation at three different locations as seen in Figure 4-2, and the drain pipe drained to the leak detection sump. 
The leak detection drain slot design was first used in construction of the 241-AW tank farm foundations because a pipefitter strike threatened to delay the project, as noted in RPP-RPT-55981, 241-AW Tank Farm Construction Extent of Condition Review for Tank Integrity. The leak detection drain slot in the 241-AP tank farm foundations stop at the 8-in. curb where they drain into a section of drain pipe imbedded in the concrete, as seen in Figure 4-3. The drain pipe extends to the edge of the foundation where it is then connected to an encased drain line manifold, which drains to a common leak detection sump that services four tanks. In the 241-AP tank farm, there are only two leak detection sumps, with four tanks draining to each. This is an important distinguishing characteristic from all of other DST farm designs.

\subsection{SECONDARY LINER BOTTOM}

The secondary liner measures 80 -ft. in diameter. The plates in the liner bottom are 3/8-in. thick carbon steel and the bottom knuckles are 9/16-in. thick carbon steel. This thickness is increased from the 1/4-in. thick bottoms and bottom knuckles of the 241-AY tank farm secondary liners.

The secondary liner bottoms for the 241-AP tank farm were constructed onsite, as shown in Figure 4-4 and Figure 4-5. Many of the tank bottoms were constructed over cribbing in neighboring locations prior to being moved by crane to their final location.

Before beginning the fabrication of a secondary liner bottom over a tank foundation, crews would place a layer of plywood over the reinforced concrete foundation. Staging was then erected to provide an elevated structure on which to fabricate the tank bottom. Elevating the tank bottom allowed access to its underside for fabrication purposes. During construction of the 241-AP tank farm, crews made use of unused level space

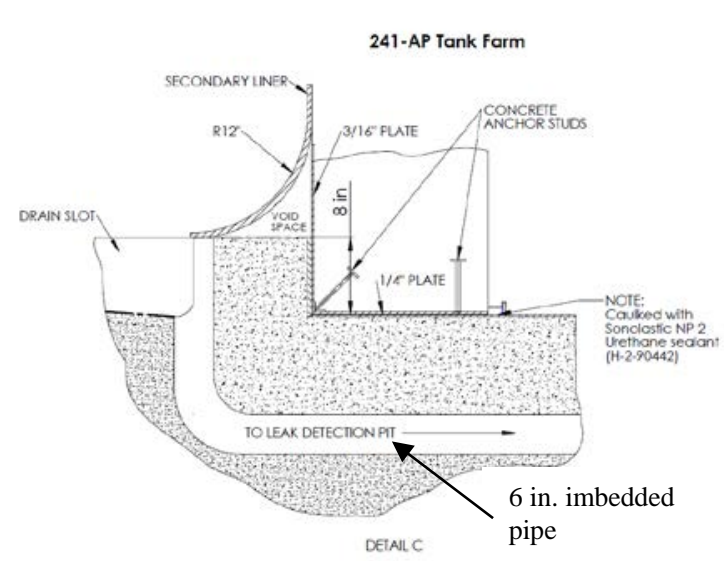

Figure 4-3. 241-AP Foundation Leak Detection System Design

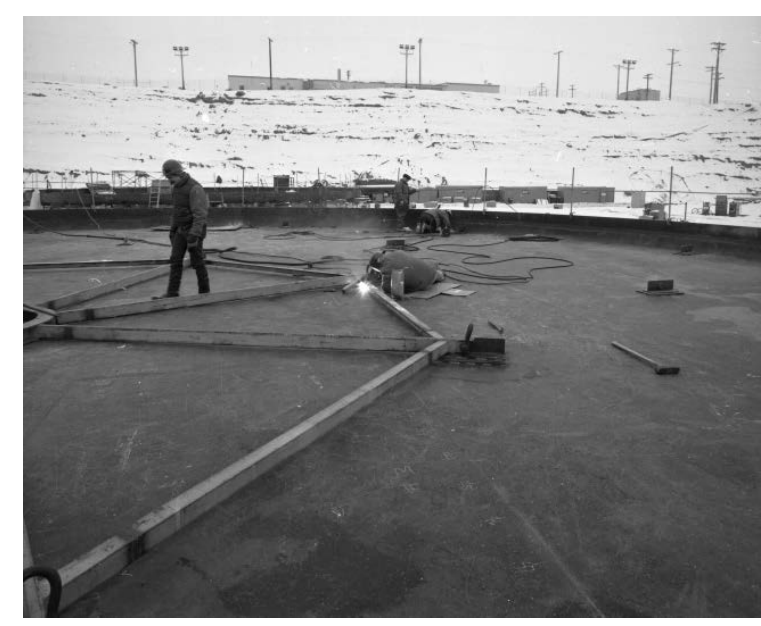

Figure 4-4. Fabrication of Secondary Liner Bottom. (Photo 110871-1) (Tank 12/28/1983)

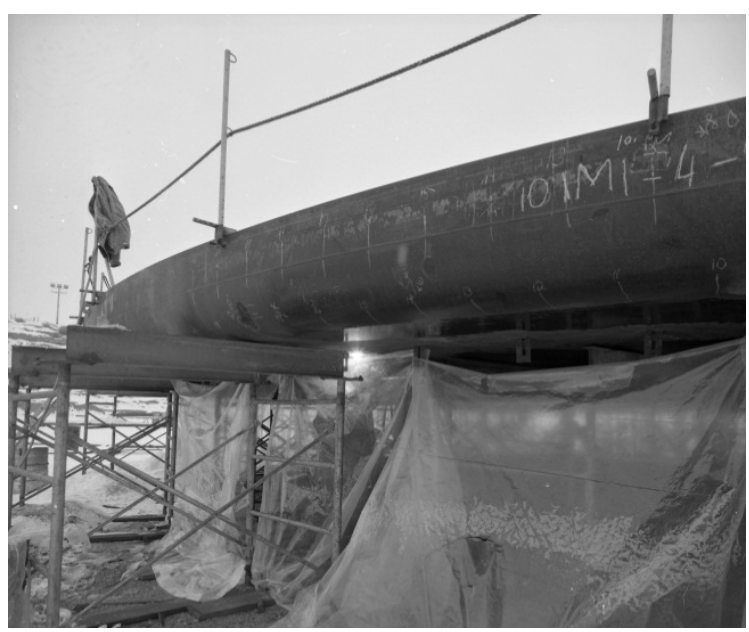

Figure 4-5. Fabrication of Secondary Liner Bottom. (Photo 110871-3)

(Taken 12/28/1983) 
between tanks AP-103 and AP-105, and AP-104 and AP-106 when constructing both secondary and primary tank bottoms.

Individual plates were installed using fit-up tools to secure the plates within allowable tolerance for proper welding. The secondary liner bottom knuckles, which are 9/16-in. thick carbon steel, were fabricated offsite at Hogan Manufacturing, prior to being shipped to the worksite for welding to join the knuckles with the adjacent plates.

After completion and inspection of the welds, the secondary liner bottom was lowered or moved onto its foundation using two cranes. This placement can be seen in progress in Figure 4-6. Lifting lugs were installed as part of a superstructure used to support the tank liner from above to limit deformation during the move.

\subsection{REFRACTORY}

The refractory design used for the 241-AP tank farm tanks specified a nominal 8-in. thick layer of refractory material to be located between the primary tank bottom and secondary liner bottom. Litecrete $60 \mathrm{M}$ was the refractory material used in the 241-AP tank farm. The primary purpose of the refractory was to act as an insulating barrier between the primary tank and the concrete foundation during post-weld stress relieving where temperatures of up to $1100^{\circ} \mathrm{F}$ were required in the primary tank. The refractory would prevent the structural concrete

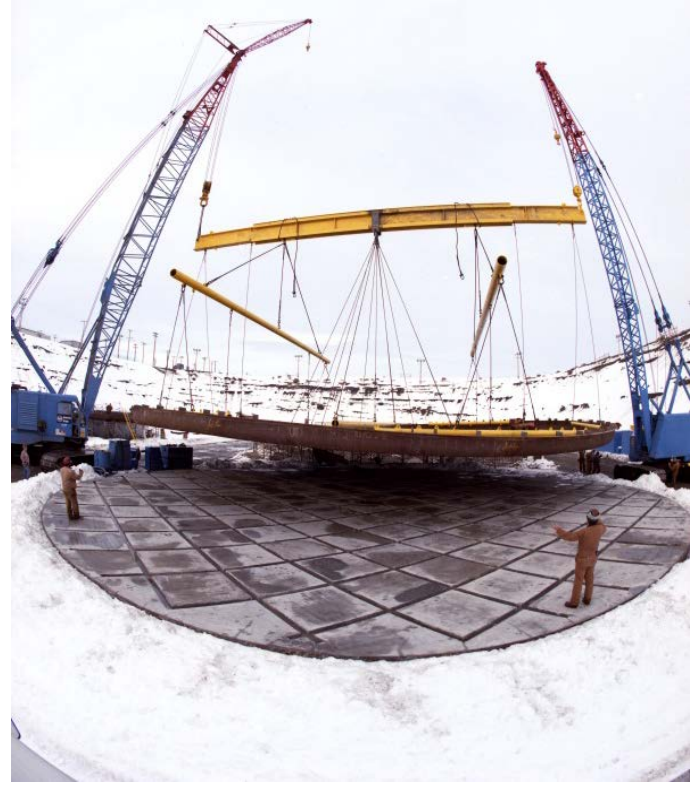

Figure 4-6. Transporting a Secondary Liner Bottom from Cribbing to Foundation (Photo 8400302-36cn) (Taken 1/4/1984) temperature from rising above $500^{\circ} \mathrm{F}$.

The refractory pad housed air supply piping, thermocouple conduit, and air distribution slots. The air distribution slots allowed airflow to cool the primary tank bottom and to direct potential leaks to the tank annulus where leak detectors are located (see $\mathrm{H}$-290440, Structural Insulating Concrete Plan and Details, for details). The eight air supply pipes (shown in Figure 4-7) terminate at the center of the tank at an air distribution ring.

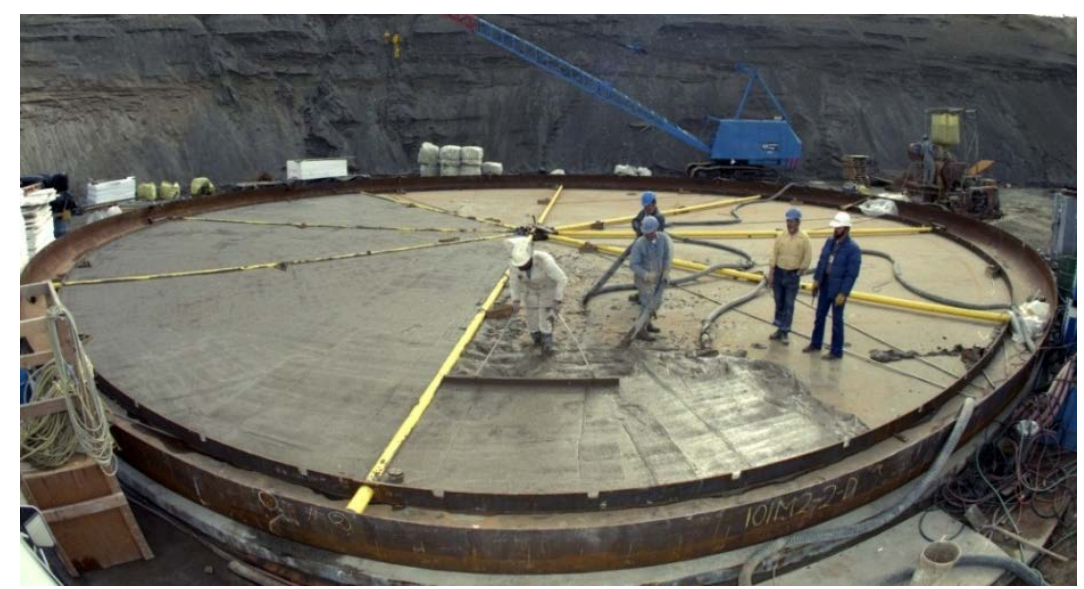

Figure 4-7. Refractory Placement (Photo 8401213-32cn) (Taken 2/24/1984) 
After reaching the center air distribution ring, the air travels toward the annulus through air distribution slots that are cast into the refractory to be exhausted through annulus risers.

Prior to placing the refractory, a 7-in. by 3/4-in. carbon steel stiffener ring was installed around the perimeter of the pour and thermocouple conduits were installed. The stiffener ring was used as a refractory form.

Thermocouples allowed temperature monitoring of the refractory and primary tank bottom during post-weld stress relieving. Forms were used to create the air

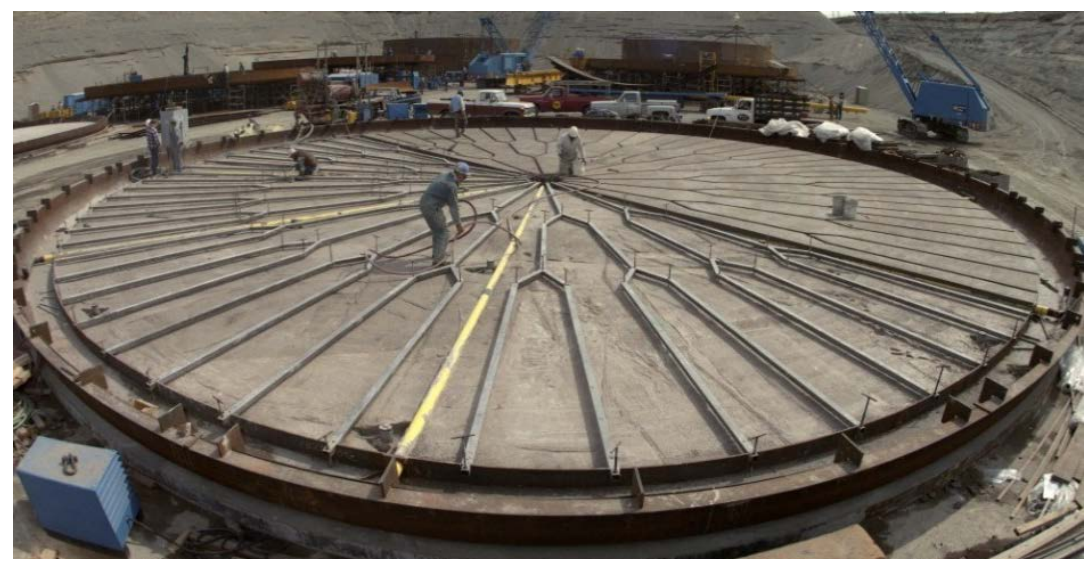

Figure 4-8. Refractory Air Distribution Slot Forming (Photo 8402704-14cn) (Taken 4/18/1984)

distribution slots in the refractory. These forms can be seen in Figure 4-8.

To protect the refractory from damage, it was placed during the warmer months, and covered with a plastic sheeting to prevent it from getting wet. This protection was utilized to prevent degradation of the refractory material as a result of excess moisture and freezing. Damage to refractory as a result of excess moisture and freezing had occurred during previous tank farm construction projects.

\subsection{PRIMARY TANK BOTTOM}

The primary tank measures 75-ft. in diameter. The 4-ft. diameter center plate of the liner bottom is 1-in. thick carbon steel, while the bottom knuckles are 15/16-in. thick carbon steel. The remainder of the plate in the primary tank bottom is1/2-in. thick carbon steel, except a 7/8-in. thick plate is used to transition between the 1/2-in plate and 15/16in. knuckle. This thickness is an increase from over the 3/8-in. thick bottoms of the 241-AY tank farm primary tanks. Following completion of refractory installation, the primary tank bottom was fabricated using a sequence similar to that used for the secondary

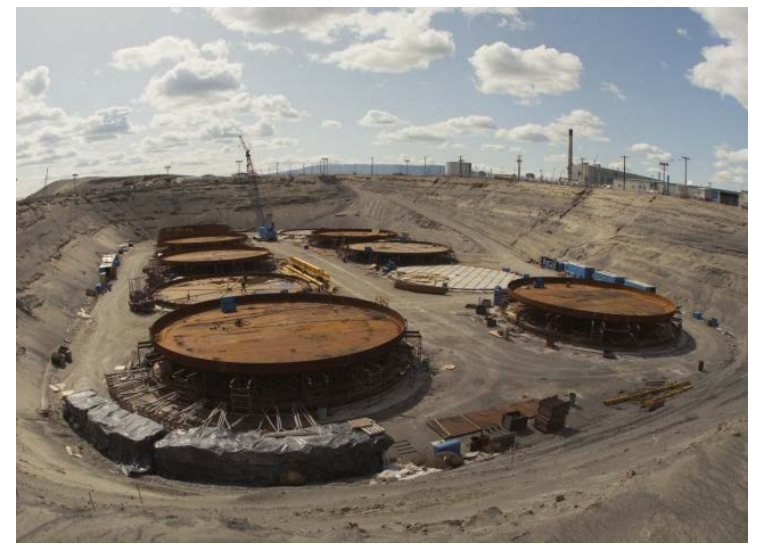

Figure 4-9. Primary Tank Bottom Erection (Photo 8402306-5cn) (Taken 3/28/1984) liner bottom. For the primary tank bottoms not using the previously erected staging between the tanks, a protective layer of plywood was placed on the refractory and staging was erected to support the liner during construction as shown in Figure 4-9. The bottom plates of the tank were installed on the staging using fit-up tools to allow proper welding. Once the top and bottom sides of the primary tank bottom were completely welded, the knuckle was welded on to the 
bottom plate. After inspection of the welds, the primary tank was then transferred to its final location and lowered onto the refractory.

\subsection{PRIMARY TANK WALL AND TANK DOME}

The primary tank measures 75 -ft in diameter to the center of the vertical plate. The primary tank wall is made up of four courses of carbon steel plates between the lower and upper knuckles. The plates in the first course are 3/4-in. thick, the next course is 9/16-in. thick and the upper two courses are 1/2 in. thick. Each course was set in place and welded to the previous course. A 7/8-in. transition plate is welded to the top of the 15/16-in. lower knuckle. The first course plates were welded to the $7 / 8$-in. thick transition plate, while the fourth course plates were welded to the 1/2-in. thick upper knuckle.

The dome of the tank was constructed of two courses of 3/8-in. thick carbon steel plate welded to the upper knuckle and closed with a circular shaped, 1/2-in. thick top dollar plate. To facilitate the installation of tank dome plates, staging was erected inside the primary tank. This staging provided a resting place for the tank dome plates for proper fit-up and welding as shown in Figure 4-10. Once the dome was welded together, riser penetration holes were cut and pipes were welded to the tank dome plates. These penetrations served as access points for the remainder of construction and they supported the installation of permanent and temporary equipment during operation. Once the penetrations were installed on the dome, it was lifted by crane and set on the upper knuckle, where it was welded in place as shown in Figure 4-11 and Figure 4-12.

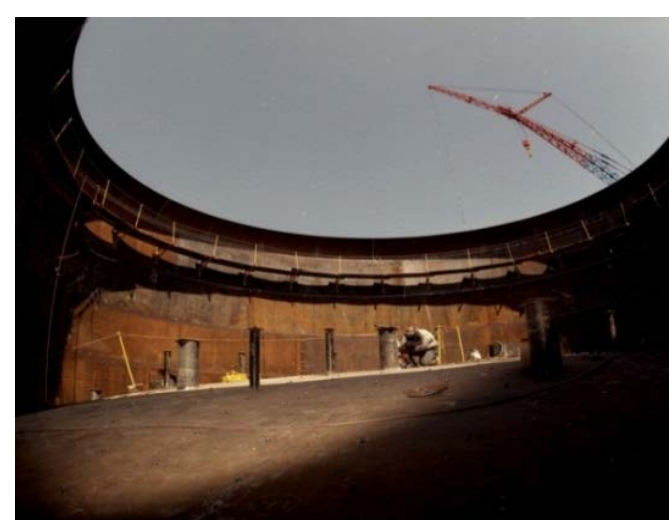

Figure 4-10. Primary Tank Dome Erection (Photo 8405415-34cn) (Taken 8/1/1984)

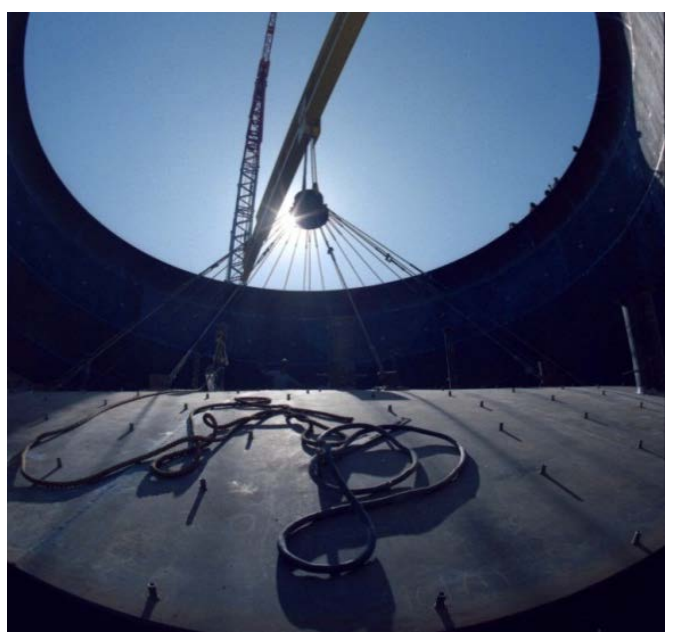

Figure 4-11. Lifting of the Primary

Tank Dome (Photo 8405145-67cn)

(Taken 8/1/1984)

Once construction of the primary tank was completed, the surfaces were cleaned. At this time the door sheet, a plate left out of a lower course to allow tank access, was welded into place in preparation for stress relief and hydrostatic testing.

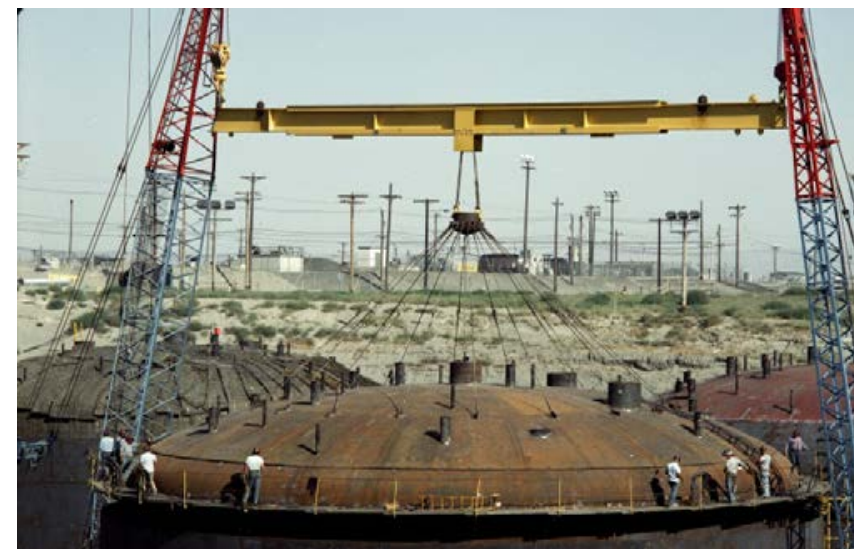

Figure 4-12. Lifting Primary Tank Dome (Photo 8405415-85cn) (Taken 8/1/1984) 


\subsection{SECONDARY LINER WALL}

Once the primary tank wall was constructed, the secondary liner wall was begun. The secondary liner wall is made up of four courses of 3/8-in. thick carbon steel plates between the lower and upper knuckles. Each course was set in place and welded to the previous course as shown in Figure 4-13. A 1/2-in. thick transition plate was welded to the top of the 9/16-in. lower knuckle. The first course plates are welded to the 1/2-in. thick transition plate, while the fourth course plates are welded to the 3/8-in. thick upper knuckle.

To maintain access to the annulus, the upper knuckle was not installed on the secondary tank liner until after stress relieving and hydrostatic testing of the primary tank.

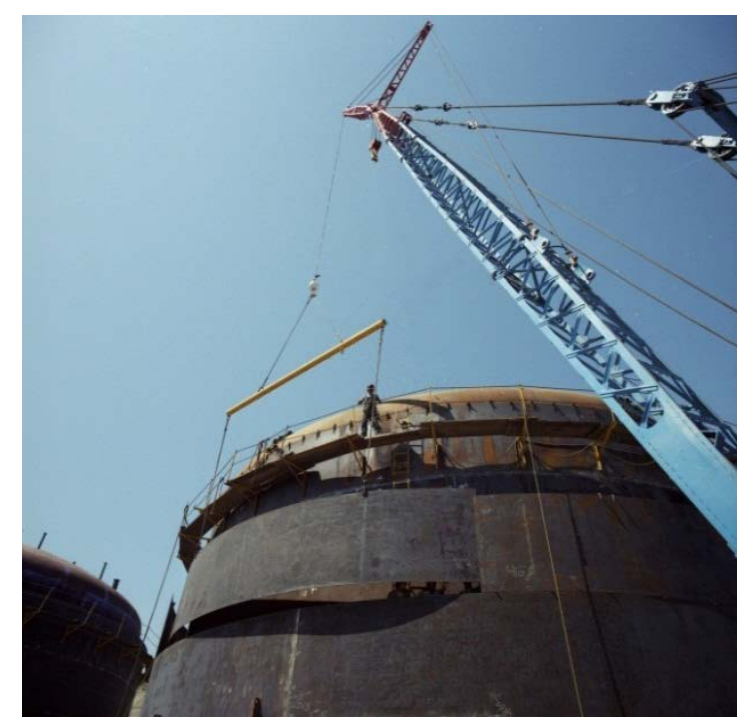

Figure 4-13. Secondary Liner Wall Erection (Photo 8405415-37cn) (Taken 8/1/1984)

\subsection{PRIMARY TANK STRESS RELIEVING}

To prepare the tank for post-weld stress relief, insulation was installed on the outer surface of the primary tank, including the dome penetrations, to help regulate the heating of the primary tank. The refractory placed to protect the structural concrete also served to insulate the bottom of the tank.

Propane gas was supplied from three 1000 gal storage tanks, passed through vaporizers, and ignited at four high velocity burners mounted on risers at the top of each tank. Figure 4-14 shows the post-weld stress relief insulation on the AP-102 primary tank. Figure 4-15 shows the burner layout utilized during stress

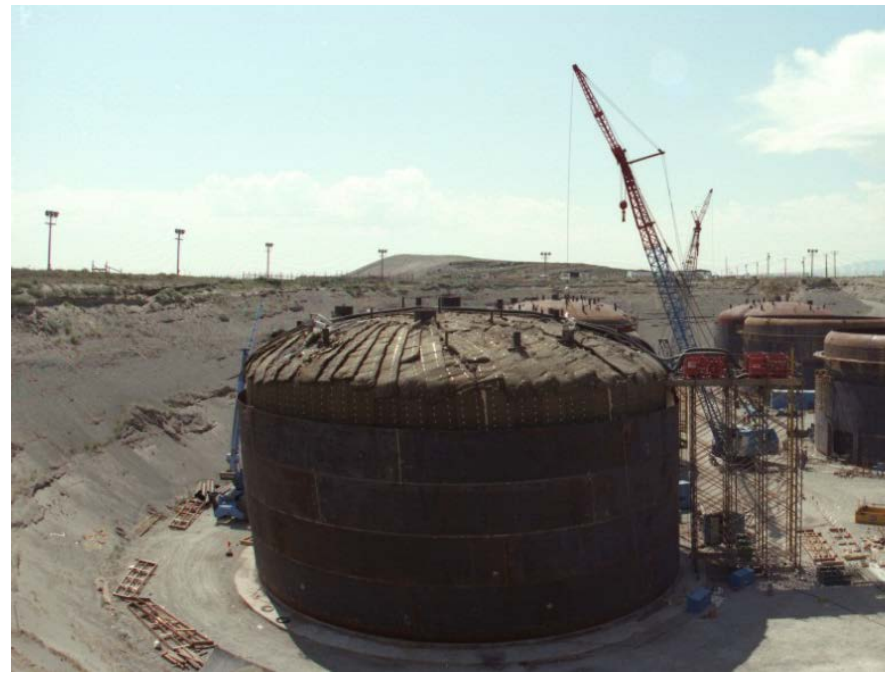

Figure 4-14. Insulation for Post-Weld Stress Relief of Tank AP-102 (Photo 8405415-2cn) (Taken 8/1/1984) relief.

The requirements for stress relieving were in accordance with ASME Boiler and Pressure Vessel Code, Section VIII (1980), which specified a preferred holding, or "soaking," temperature of $1100^{\circ} \mathrm{F}$ for one hour per inch of metal thickness. 
Division 15, Section 3.4, "Stress Relieving," of B-340-C4, Construction Specification for Primary and Secondary Steel Tanks 241-AP Tank Farm Work Order X34001, provided the following direction for stress relieving:

"3.4.2 Perform stress relief in accordance with ASME, Section VIII, Division 2, Article F-4, except that:

3.4.2.1 The maximum allowable decrease in temperature below the specified temperature of $1100 \mathrm{~F}$ shall not exceed $100 \mathrm{~F}$.

3.4.2.2 The temperature shall be brought from ambient to $220 \mathrm{~F}$ and held for 6 hours.

3.4.2.3 The rate of temperature rise and reduction between $800 \mathrm{~F}$ and $1100 \mathrm{~F}$ shall be no more than $100 \mathrm{~F} / \mathrm{hr}$.

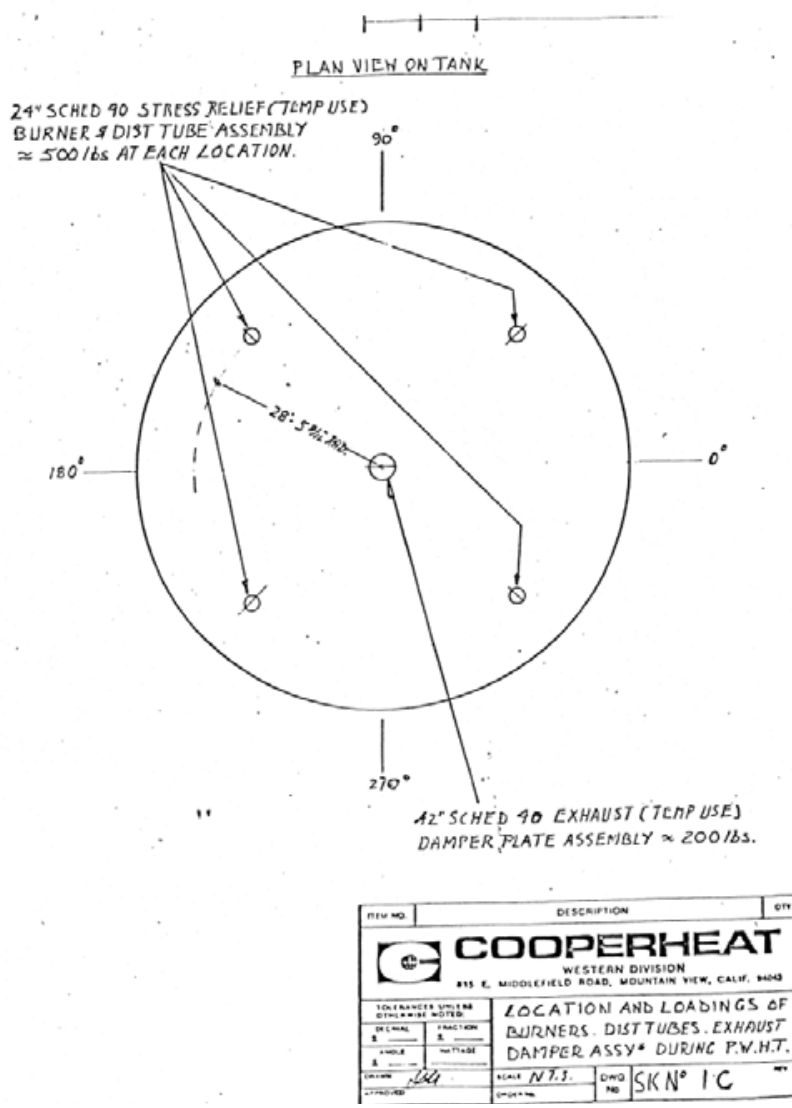

Figure 4-15. 241-AP Post Weld Stress Relief Burner Layout

\subsubsection{The period of heating}

from 800 F to 1100 F shall consume no more than 12 hours.

3.4.2.5 During the heating-up period, after any recorded temperature reaches $800 \mathrm{~F}$, the temperature of all parts of the tank being heated shall be uniform with a maximum temperature differential at any time of $200 \mathrm{~F}$."

Although construction specification B-340-C4 specifies a stress relief temperature of $1100^{\circ} \mathrm{F}$, alternative temperature and time requirements were allowed. During 241-AW tank farm construction, dome deformations in tank AW-101 due to stress relief at $1100^{\circ} \mathrm{F}$ triggered a change in the stress relieving procedure (see RPP-RPT-55981, 241-AW Tank Farm Construction Extent of Condition Review for Tank Integrity, for details). The change resulted in less severe dome distortion. To prevent similar dome distortions in the 241-AP tank farm, the requirement of a soak temperature of $1000^{\circ} \mathrm{F}$ for three hours was applied. Following review of the time vs. temperature logs of stress relief, it is clear that tanks AP-101 through AP-107 were stress relieved at $1000^{\circ} \mathrm{F}$ for at least three hours. Tank AP-108 was stress relieved at $950^{\circ} \mathrm{F}$ for 5 hours due to low thermocouple readings. See Section 5.2 for a description of the tank AP-108 post-weld stress relief issues. 
Thermocouples were installed throughout the tank to measure the temperature on the inside. Thermocouples installed during the insulating refractory pour were used to monitor the post-weld stress relieving temperatures in the primary tank bottom during the operation. Heating occurred in several stages and key events were captured in inspection reports. See Table 4-1 for significant post-weld stress relieving highlights.

Table 4-1. Post-Weld Stress Relieving in the 241-AP Farm

\begin{tabular}{|c|c|c|c|c|}
\hline Tank & Burners Turned On & $\begin{array}{l}\text { Completed 6-hr } \\
\text { Hold Time at } \\
220^{\circ} \mathrm{F}\end{array}$ & $\begin{array}{c}\text { Completed Final } \\
\text { 3-hr Hold Time at } \\
1000^{\circ} \mathrm{F}\end{array}$ & $\begin{array}{c}\text { All Thermocouples } \\
\text { Reading below } \\
800^{\circ} \text { F, Recorders } \\
\text { Turned Off }\end{array}$ \\
\hline AP-101 & $\begin{array}{l}\text { 6:30 a.m. } \\
\text { August 16, } 1984\end{array}$ & $\begin{array}{c}\text { 2:00 p.m. } \\
\text { August 16, } 1984\end{array}$ & $\begin{array}{l}\text { 10:45 a.m. } \\
\text { August 17, } 1984\end{array}$ & $\begin{array}{c}\text { 1:00 p.m. } \\
\text { August 17, } 1984\end{array}$ \\
\hline AP-102 & $\begin{array}{c}\text { 6:30 a.m. } \\
\text { August 2, } 1984\end{array}$ & $\begin{array}{c}\text { 3:30 p.m. } \\
\text { August 2, } 1984\end{array}$ & $\begin{array}{c}\text { 7:30 a.m. } \\
\text { August 3, } 1984\end{array}$ & $\begin{array}{c}\text { 10:30 a.m. } \\
\text { August 3, } 1984\end{array}$ \\
\hline AP-103 & $\begin{array}{l}\text { 7:00 a.m. } \\
\text { September } 18,1984\end{array}$ & $\begin{array}{c}\text { 4:00 p.m. } \\
\text { September 18, } 1984\end{array}$ & $\begin{array}{l}\text { 2:00 p.m. } \\
\text { September } 19,1984\end{array}$ & $\begin{array}{l}\text { 7:00 p.m. } \\
\text { September } 19,1984\end{array}$ \\
\hline AP-104 & $\begin{array}{l}\text { 7:00 a.m. } \\
\text { September 12, } 1984\end{array}$ & $\begin{array}{l}\text { 4:00 p.m. } \\
\text { September 12, } 1984\end{array}$ & $\begin{array}{c}\text { 1:00 p.m. } \\
\text { September 13, } 1984\end{array}$ & $\begin{array}{c}\text { 4:00 p.m. } \\
\text { September } 13,1984\end{array}$ \\
\hline AP-105 & $\begin{array}{l}\text { 9:30 a.m. } \\
\text { October 2, } 1984\end{array}$ & $\begin{array}{c}\text { 6:30 p.m. } \\
\text { October 2, } 1984\end{array}$ & $\begin{array}{l}\text { 2:00 p.m. } \\
\text { October 3, } 1984\end{array}$ & $\begin{array}{c}\text { 3:30 p.m. }{ }^{\mathrm{A}} \\
\text { October } 3,1984\end{array}$ \\
\hline AP-106 & $\begin{array}{c}\text { 6:30 a.m. } \\
\text { August 28, } 1984\end{array}$ & $\begin{array}{c}\text { 3:30 p.m. } \\
\text { August 28, } 1984\end{array}$ & $\begin{array}{c}\text { 1:00 p.m. } \\
\text { August 29, } 1984\end{array}$ & $\begin{array}{c}\text { 5:30 p.m. } \\
\text { August 29, } 1984\end{array}$ \\
\hline AP-107 & $\begin{array}{l}\text { 8:00 a.m. } \\
\text { July } 19,1984\end{array}$ & $\begin{array}{l}\text { 5:15 p.m. } \\
\text { July } 19,1984\end{array}$ & $\begin{array}{l}\text { 1:00 p.m. } \\
\text { July 20, } 1984\end{array}$ & $\begin{array}{l}\text { 5:00 p.m. } \\
\text { July 20, } 1984\end{array}$ \\
\hline AP-108 & $\begin{array}{c}\text { 9:00 a.m. } \\
\text { July 6, } 1984\end{array}$ & $\begin{array}{l}\text { 6:00 p.m. } \\
\text { July 6, } 1984\end{array}$ & $\begin{array}{l}\text { 7:00 p.m. } \\
\text { July } 7,1984\end{array}$ & $\begin{array}{l}\text { 11:00 p.m. } \\
\text { July 7, } 1984\end{array}$ \\
\hline
\end{tabular}

\subsection{PRIMARY TANK HYDROSTATIC TEST}

After completion of post-weld stress relieving, the heating equipment and temporary insulation were removed in preparation for hydrostatic testing to begin. Hydrostatic testing equipment can be seen in Figure 4-16.

Division 15, Section 3.5, "Hydrostatic Test," of B-340-C4, Construction Specification for Primary and Secondary Steel Tanks 241-AP Tank Farm Work Order X34001, provided the following direction for hydrostatic testing:

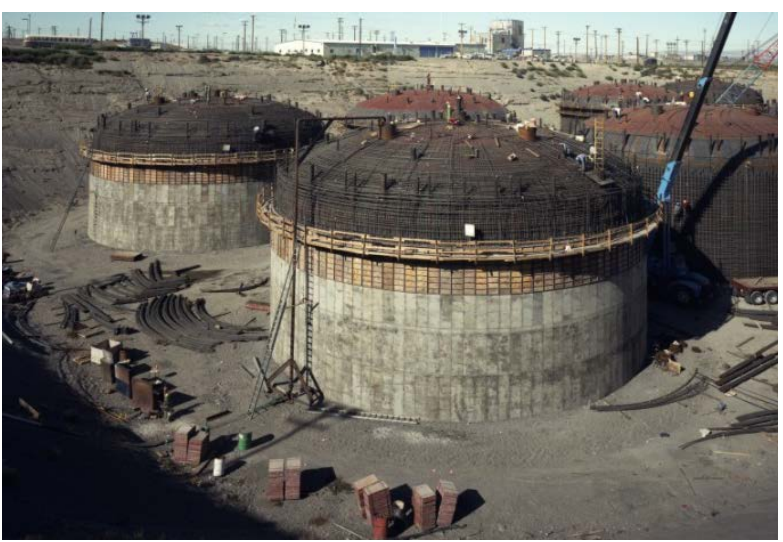

Figure 4-16. Equipment for Hydrostatic Test Water Fill on Tank AP-108 (Photo 84074952cn) (Taken 10/1/1984) 
"3.5.1 After the tank has been stress relieved, apply a full hydrostatic test to the primary tanks by filling with water to a depth of 40 feet from the bottom of the tank to bottom of top riser plus or minus 1 inch. Use one of the vertical risers near the center of the tank dome for introduction of water. To allow air to escape from the tank during the test, provide air bleed ports in the other vertical risers. Tank surfaces to be examined shall be dry. Coat all accessible welded joints below the water level with a mixture of blue chalk and water or alcohol. All water in the primary tanks, regardless of source or length of retention, shall be treated to provide a chemical residual of $\mathrm{OH}=0.01 \mathrm{M}$ and $\mathrm{NO} 2=$ 0.011M. Cathodic protection may be used per DT-1520 A106.

\subsubsection{Maintain the hydrostatic pressure for a minimum of 24 hours.}

3.5.3 Leak detection shall be by visual examination of each welded joint previously coated with a mixture of blue chalk and water or alcohol."

Corrosion inhibitors were applied to the water for hydrostatic testing. This is the first double-shell tank known to have used corrosion inhibitors in the hydrostatic testing procedure. It is noted in NCR B-340-118 (see App. Figure B-48), that 3500 pounds of sodium bicarbonate was mixed into the water.

After hydrostatic testing for each tank was complete, more water was pumped into the tank to fill it to the dome. The water would then act as support for the dome while the dome concrete was being poured. The water remained in the tanks for several months before being pumped out. Table 4-2 provides the date that each tank's hydrostatic test was accepted.

Table 4-2. Hydrostatic Test Dates

\begin{tabular}{|c|c|}
\hline Tank & Hydrostatic Test Accepted \\
\hline AP-101 & November 21, 1984 \\
\hline AP-102 & November 9, 1984 \\
\hline AP-103 & December 14, 1984 \\
\hline AP-104 & December 6, 1984 \\
\hline AP-105 & December 17, 1984 \\
\hline AP-106 & November 29, 1984 \\
\hline AP-107 & October 26, 1984 \\
\hline AP-108 & October 22, 1984 \\
\hline
\end{tabular}

\subsection{COMPLETE SECONDARY LINER WALL AND TANK PENETRATIONS}

Once the hydrostatic testing was completed, the secondary liner top knuckle was installed and welded to the secondary liner vertical wall section. The secondary liner knuckle is not welded to the primary tank. By design, a 1-in. maximum allowed gap exists between the primary tank dome and the edge of the secondary liner knuckle. To cover the gap and prevent the collection 
of debris or concrete in the annulus during the remaining construction, metal flashing was tack welded to the primary tank over the outside of the secondary top knuckle.

To retain access to the annulus space, penetrations were installed in the upper knuckle of the secondary liner. These penetrations were used for tank annulus processing and monitoring activities, such as ventilation, annular inspection, instrument leads, and construction access. These penetrations can be seen in Figure 4-17

\subsection{CONCRETE POUR}

The concrete shell measures 83-ft. in outside diameter and is 1 -ft. 5 5/8-in. thick; it rests on a 3/8-in. thick steel slide plate and 1/4-in. thick bearing plate that are supported by the tank foundation.

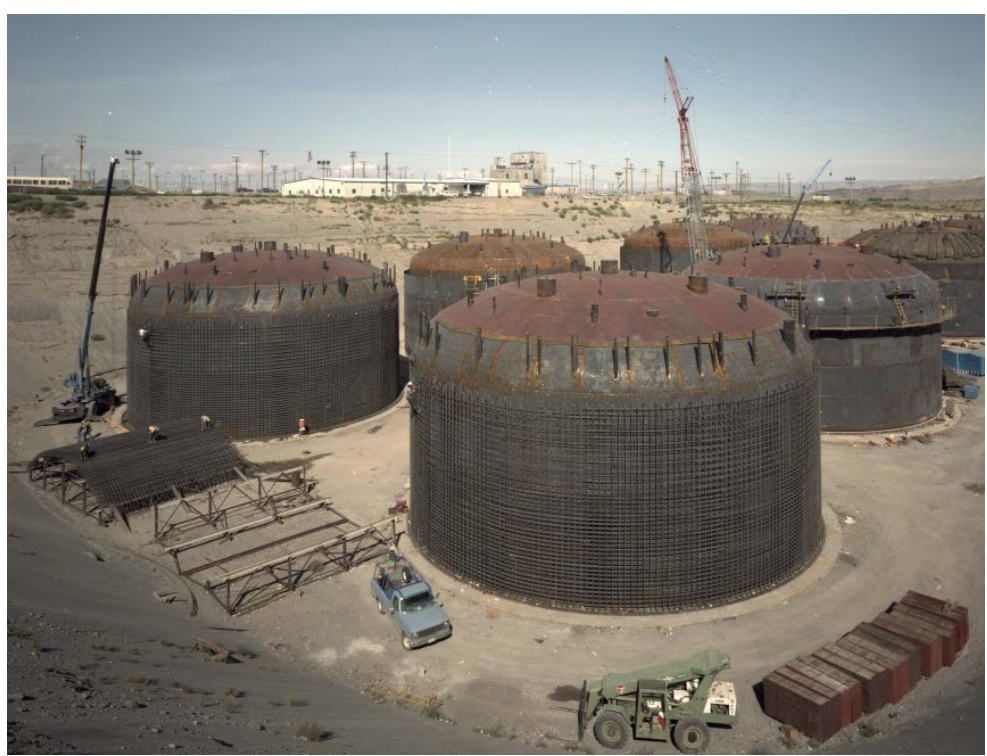

Figure 4-17. Secondary Liner and Penetration Completion (Photo 8405795-1cn) (Taken 9/10/1984) These plates ran the full circumference of the wall and two sets of anchor studs were mounted on the slide plate to help anchor the concrete wall.

Rebar used to reinforce the concrete was installed around the tank and over the dome before the concrete was poured. Once the rebar skirts were installed, the outer forms were set in place; the secondary liner's outer wall acted as the inner concrete form. The shell was poured in four parts: two vertical lifts on the sides of the tank, one that covered the upper knuckle of the secondary liner, and

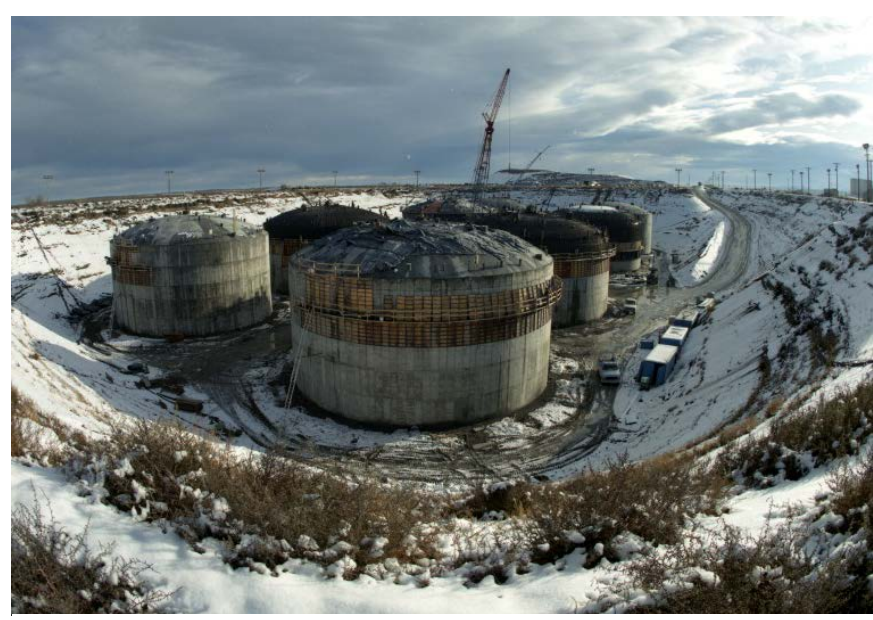

Figure 4-18. Concrete Dome Pour on Tank AP-101 (Photo 8407523-9cn) (Taken 11/30/1984) one pour to cover the dome. The concrete shell is shown to be nearly complete on tank AP-101 in Figure 4-18. Keyed construction joints connected each new pour to the previous section. After hydrostatic testing was finished, more water was added to the tank to fill it to the top of the dome. The water supported the dome during the concrete dome pour and was pumped out after the concrete was set.

\subsection{LEAK DETECTION SYSTEM}

Once the vertical section of concrete had been placed, the leak detection system was installed. The leak detection system consisted of a leak detection drain coming from the foundation of the 
tank, a drain manifold and a shared leak detection sump, and leak detection well which extended from the sump up to ground level. There were two leak detection sumps installed for all the 241-AP tank farm tanks. Each sump services four tanks.

\subsection{TANK APPURTENANCES}

After completing the concrete pours, the water used to support the steel dome during concrete pouring was pumped out. The equipment to be placed in the interior of the tank was then installed. These pieces of equipment were welded to the existing penetrations that had been installed on the tank dome prior to the tank stress relief.

\subsection{POST-CONSTRUCTION RISER INSTALLATION}

After tank farm construction completion, a decision was made to install a single new 42-in. riser with a pit, and two additional pits on existing 42-in. risers in each of two tanks in the 241-AP tank farm. While both tank AP-107 and AP-108 were selected to receive new pits, a budget reduction reduced the scope of the project to include a new riser and pits only in tank AP-107 (see App. Figure A-2). All project design and specification documents were still required to include tank AP-108. The pits would house agitator pumps to remove liquid waste from the tanks for the waste grout project. The project was designated Project W-E01, 107-AP and 108-AP Tank Farm Riser/Pit Installation, and the formal kickoff date was May 5, 1988.

The new 42 in. riser location encompassed the existing penetration \#7, 12-in. vent line. The new 42-in. riser became penetration \#7 (see H-14-010503, Dome Penetration Schedules (WST/WSTA) Tank 241-AP-107). Excavation was completed down to tank dome AP-107. A 7-ft. diameter section of concrete was removed without cutting or damaging the rebar. Rebar was cut out, and a hole was cut in the steel dome at approximately 19-ft. 5 3/4-in. from tank centerline and $27^{\circ}-14^{\prime}-11^{\prime \prime}$ North of East.

The riser was welded to the tank dome and rebar was welded in place using the configuration shown on H-2-77447, STRL, Tank Dome Penetration Plan and Details. New concrete with a required 5000 psi, 28-day compressive strength, was placed around the new riser using ASTM C150, Type II cement. The area was then backfilled, and pump pits were constructed.

A structural analysis was completed for the addition of a 42-in. riser (as seen in, Integrated Data Management System (IDMS), Queried 2/5/2014, [241-AP-107 Riser Installation Structural Analysis Project W-E01], http://idmsweb.rl.gov/idms/livelink.exe). The use of stress relief after the riser installation was discussed in correspondence (see App. Figure A-3); however, it is unclear if the dome was stress relieved following riser installation. The project was completed on September 30, 1988 (see App. Figure A-4).

Complete information for this project was not located. None of the documentation specified how the concrete was removed without damaging the concrete around it or without cutting the rebar, although, it was mentioned that a demonstration was planned on some mockup concrete (see App. Figure A-5). Also, there was no specific information on what method was used to cut the steel dome, or how they kept the cut piece from falling into the tank. 


\subsection{CONSTRUCTION ISSUES}

This section provides a detailed review of the construction issues identified during the fabrication of the 241-AP tank farm. This information has been compiled from a review of the Quality Assurance (QA) construction, inspection sheets, memos, drawings, photos, construction records, and post-construction reports.

\subsection{WELDING AND NON-DESTRUCTIVE EXAMINATION}

\subsubsection{Non-Destructive Examination Methods Utilized}

Throughout construction of the primary tank and secondary liner, non-destructive examination (NDE) was required. The level of NDE varied between the primary tank and secondary liner and with elevation on the tank wall. The change in NDE relative to elevation was based on the planned use of the tank to contain waste up to a specific elevation. Table 5-1 provides a summary of the NDE used to ensure the pedigree of the primary tank and secondary liner. Further information regarding NDE use can be found in the construction specification for the primary tank and secondary liner, B-340-C4.

Table 5-1. 241-AP Tank Farm Non-Destructive Examinations Used During Construction

\begin{tabular}{|c|c|c|}
\hline & Primary Tank Inspections & Secondary Liner Inspections \\
\hline Tank Bottom & $\begin{array}{l}\text { - } \text { Radiography - All butt welds } \\
\text { - } 100 \% \text { Magnetic particle } \\
\text { - } 100 \% \text { Liquid penetrant } \\
\text { - } 100 \% \text { Visual } \\
\text { - } \text { Hydrostatic leak test - Fill to } \\
\text { 40-ft. from bottom of the tank. }\end{array}$ & $\begin{array}{l}\text { - } \text { Radiography - All butt welds } \\
\text { - } 100 \% \text { Magnetic particle } \\
\text { - } 100 \% \text { Liquid penetrant } \\
\text { - } 100 \% \text { Visual }\end{array}$ \\
\hline Bottom Knuckle & $\begin{array}{l}\text { - } \text { Radiography - All butt welds } \\
\text { - } 100 \% \text { Magnetic particle } \\
\text { - } 100 \% \text { Liquid penetrant } \\
\text { - } 100 \% \text { Visual } \\
\text { - } \quad \text { Hydrostatic leak test - Fill to } \\
\text { 40-ft. from bottom of the tank. }\end{array}$ & $\begin{array}{l}\text { - } \text { Radiography - All butt welds } \\
\text { - } 100 \% \text { Magnetic particle } \\
\text { - } 100 \% \text { Liquid penetrant } \\
\text { - } 100 \% \text { Visual }\end{array}$ \\
\hline
\end{tabular}


Table 5-1. 241-AP Tank Farm Non-Destructive Examinations Used During Construction

\begin{tabular}{|c|c|c|}
\hline & Primary Tank Inspections & Secondary Liner Inspections \\
\hline Vertical Wall & $\begin{array}{l}\text { Radiography- All butt welds } \\
\text { including the weld of the } \\
\text { cylindrical shell to top dome } \\
\text { knuckle. } \\
\text { Magnetic particle - inside and } \\
\text { outside surfaces where clips, } \\
\text { lugs, etc. have been removed } \\
\text { and/or repaired by filing, } \\
\text { welding, grinding, etc. } \\
\text { 100\% Visual } \\
\text { - Hydrostatic leak test - Fill to } \\
\text { 40-ft. from bottom of the tank. }\end{array}$ & $\begin{array}{l}\text { Radiography - All butt welds } \\
\text { including the weld of the } \\
\text { cylindrical shell to upper } \\
\text { knuckle. } \\
\text { - } 100 \% \text { Visual }\end{array}$ \\
\hline $\begin{array}{l}\text { Upper Knuckle } \\
\text { and Tank Dome }\end{array}$ & $\begin{array}{l}\text { - } 100 \% \text { Visual } \\
\text { - } \quad \text { Hydrostatic leak test - Fill to } \\
\text { 40-ft. from bottom of the tank. }\end{array}$ & - $100 \%$ Visual \\
\hline
\end{tabular}

\subsubsection{Primary Tank Bottom Weld Film Rejection Rates}

Overall primary tank bottom radiographic film rejection rates for the 241-AP tank farm are summarized below in Table 5-2. A quantitative comparison of welding success on the 241-AP tanks is shown in Table 5-3 through Table 5-6. This same comparison was completed and included within RPP-ASMT-53793, for the 241-AY tank farm. Analysis of the tank AY-101 and tank AY-102 primary bottom radiographic test diagrams (weld maps) was completed for a second time as a part of this extent of condition effort to ensure accuracy and consistency. Those results are provided in Table 5-7 and are nearly identical to those previously tabulated, with some minor discrepancies resulting from omission of the center dollar plate welds in the primary tank bottom within RPP-ASMT-53793.

Table 5-2. 241-AP Tank Farm Primary Tank Bottom Weld Rejection Rate Summary

\begin{tabular}{|c|c|}
\hline Tank & Total Weld Reject Rate (\%) \\
\hline AP-101 & $6 \%$ \\
\hline AP-102 & $9 \%$ \\
\hline AP-103 & $10 \%$ \\
\hline AP-104 & $9 \%$ \\
\hline AP-105 & $12 \%$ \\
\hline AP-106 & $6 \%$ \\
\hline AP-107 & $\mathbf{7 \%}$ \\
\hline AP-108 & $5 \%$ \\
\hline
\end{tabular}


RPP-RPT-55983, Rev. 0

Table 5-3. Tanks AP-101 and AP-102 Primary Bottom Welding Success Comparison

\begin{tabular}{|c|c|c|c|c|c|c|}
\hline & \multicolumn{3}{|c|}{ Tank AP-101 } & \multicolumn{3}{|c|}{ Tank AP-102 } \\
\hline & $\begin{array}{c}\text { Length } \\
\text { of Weld } \\
\text { (ft) }\end{array}$ & $\begin{array}{c}\text { Reject } \\
\text { Rate per } \\
\text { Repair } \\
\text { Cycle } \\
(\%)\end{array}$ & $\begin{array}{c}\text { Total } \\
\text { Reject } \\
\text { Rate (\%) }\end{array}$ & $\begin{array}{l}\text { Length } \\
\text { of Weld } \\
\text { (ft) }\end{array}$ & $\begin{array}{l}\text { Reject } \\
\text { Rate per } \\
\text { Repair } \\
\text { Cycle } \\
(\%)\end{array}$ & $\begin{array}{c}\text { Total } \\
\text { Reject } \\
\text { Rate (\%) }\end{array}$ \\
\hline Weld prior to inspection & 735 & N/A & N/A & 735 & N/A & N/A \\
\hline Weld rejected after original weld & 47 & $6 \%$ & $6 \%$ & 65 & $9 \%$ & $9 \%$ \\
\hline Weld rejected after first repair & 2 & $4 \%$ & $6 \%$ & 8 & $12 \%$ & $9 \%$ \\
\hline Weld rejected after second repair & 1 & $50 \%$ & $6 \%$ & 0 & $0 \%$ & $9 \%$ \\
\hline Weld rejected after third repair & 0 & $0 \%$ & $6 \%$ & 0 & N/A & N/A \\
\hline Weld rejected after fourth repair & 0 & N/A & N/A & 0 & N/A & N/A \\
\hline Total weld rejections & \multicolumn{3}{|c|}{50} & \multicolumn{3}{|c|}{73} \\
\hline Total weld & \multicolumn{3}{|c|}{785} & \multicolumn{3}{|c|}{808} \\
\hline Overall weld rejection rate & \multicolumn{3}{|c|}{$6 \%$} & \multicolumn{3}{|c|}{$9 \%$} \\
\hline
\end{tabular}

Table 5-4. Tanks AP-103 and AP-104 Primary Bottom Welding Success Comparison

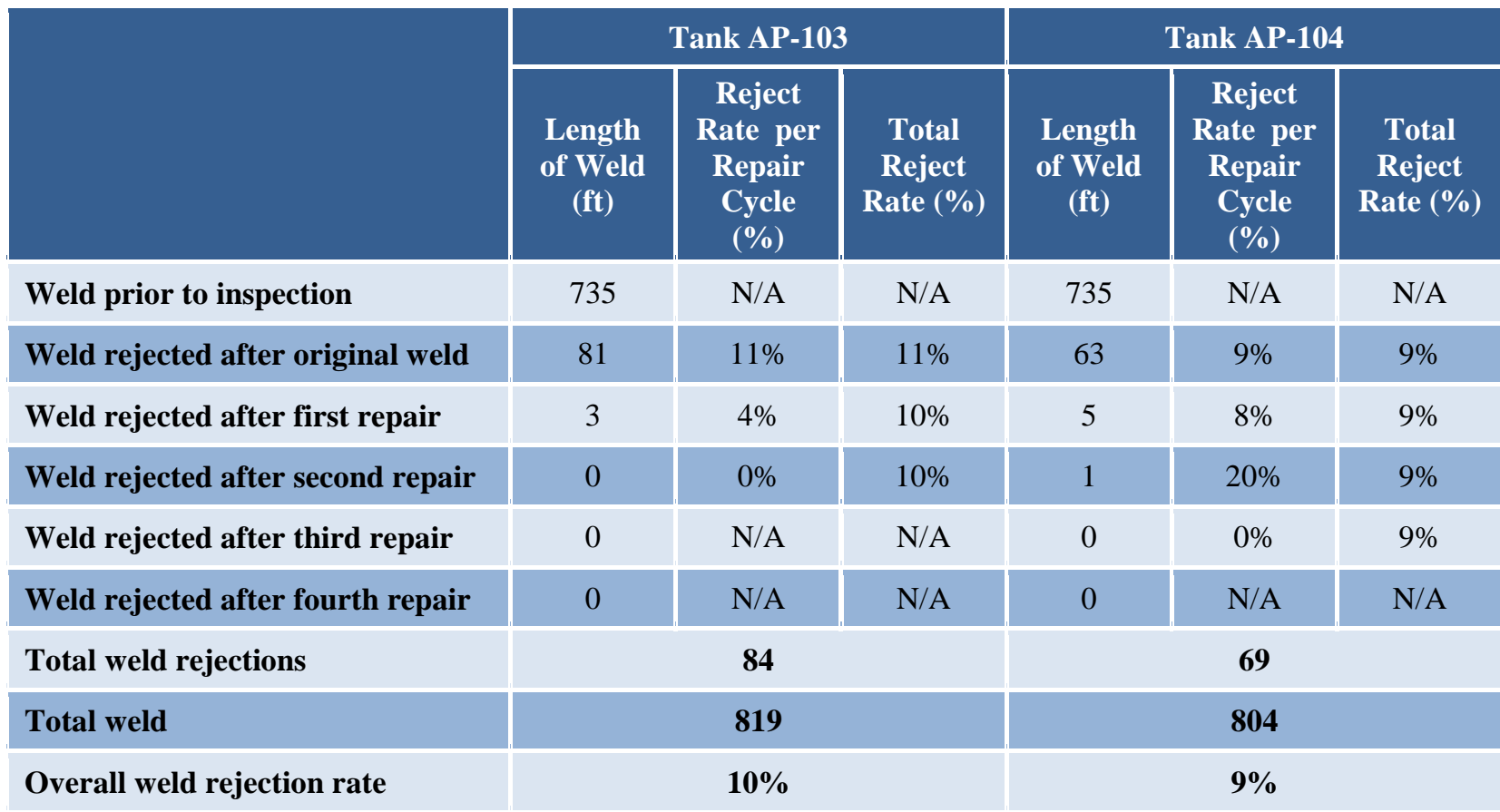


RPP-RPT-55983, Rev. 0

Table 5-5. Tanks AP-105 and AP-106 Primary Bottom Welding Success Comparison

\begin{tabular}{|c|c|c|c|c|c|c|}
\hline & \multicolumn{3}{|c|}{ Tank AP-105 } & \multicolumn{3}{|c|}{ Tank AP-106 } \\
\hline & $\begin{array}{c}\text { Length } \\
\text { of Weld } \\
\text { (ft) }\end{array}$ & $\begin{array}{c}\text { Reject } \\
\text { Rate per } \\
\text { Repair } \\
\text { Cycle } \\
(\%)\end{array}$ & $\begin{array}{c}\text { Total } \\
\text { Reject } \\
\text { Rate (\%) }\end{array}$ & $\begin{array}{c}\text { Length } \\
\text { of Weld } \\
\text { (ft) }\end{array}$ & $\begin{array}{c}\text { Reject } \\
\text { Rate per } \\
\text { Repair } \\
\text { Cycle } \\
(\%)\end{array}$ & $\begin{array}{c}\text { Total } \\
\text { Reject } \\
\text { Rate (\%) }\end{array}$ \\
\hline Weld prior to inspection & 735 & N/A & N/A & 735 & N/A & $\mathrm{N} / \mathrm{A}$ \\
\hline Weld rejected after original weld & 90 & $12 \%$ & $12 \%$ & 44 & $6 \%$ & $6 \%$ \\
\hline Weld rejected after first repair & 9 & $10 \%$ & $12 \%$ & 2 & $5 \%$ & $6 \%$ \\
\hline Weld rejected after second repair & 0 & $0 \%$ & $12 \%$ & 0 & $0 \%$ & $6 \%$ \\
\hline Weld rejected after third repair & 0 & N/A & N/A & 0 & $\mathrm{~N} / \mathrm{A}$ & N/A \\
\hline Weld rejected after fourth repair & 0 & N/A & N/A & 0 & N/A & $\mathrm{N} / \mathrm{A}$ \\
\hline Total weld rejections & \multicolumn{3}{|c|}{99} & \multicolumn{3}{|c|}{46} \\
\hline Total weld & \multicolumn{3}{|c|}{834} & \multicolumn{3}{|c|}{781} \\
\hline Overall weld rejection rate & \multicolumn{3}{|c|}{$12 \%$} & \multicolumn{3}{|c|}{$6 \%$} \\
\hline
\end{tabular}

Table 5-6. Tanks AP-107 and AP-108 Primary Bottom Welding Success Comparison

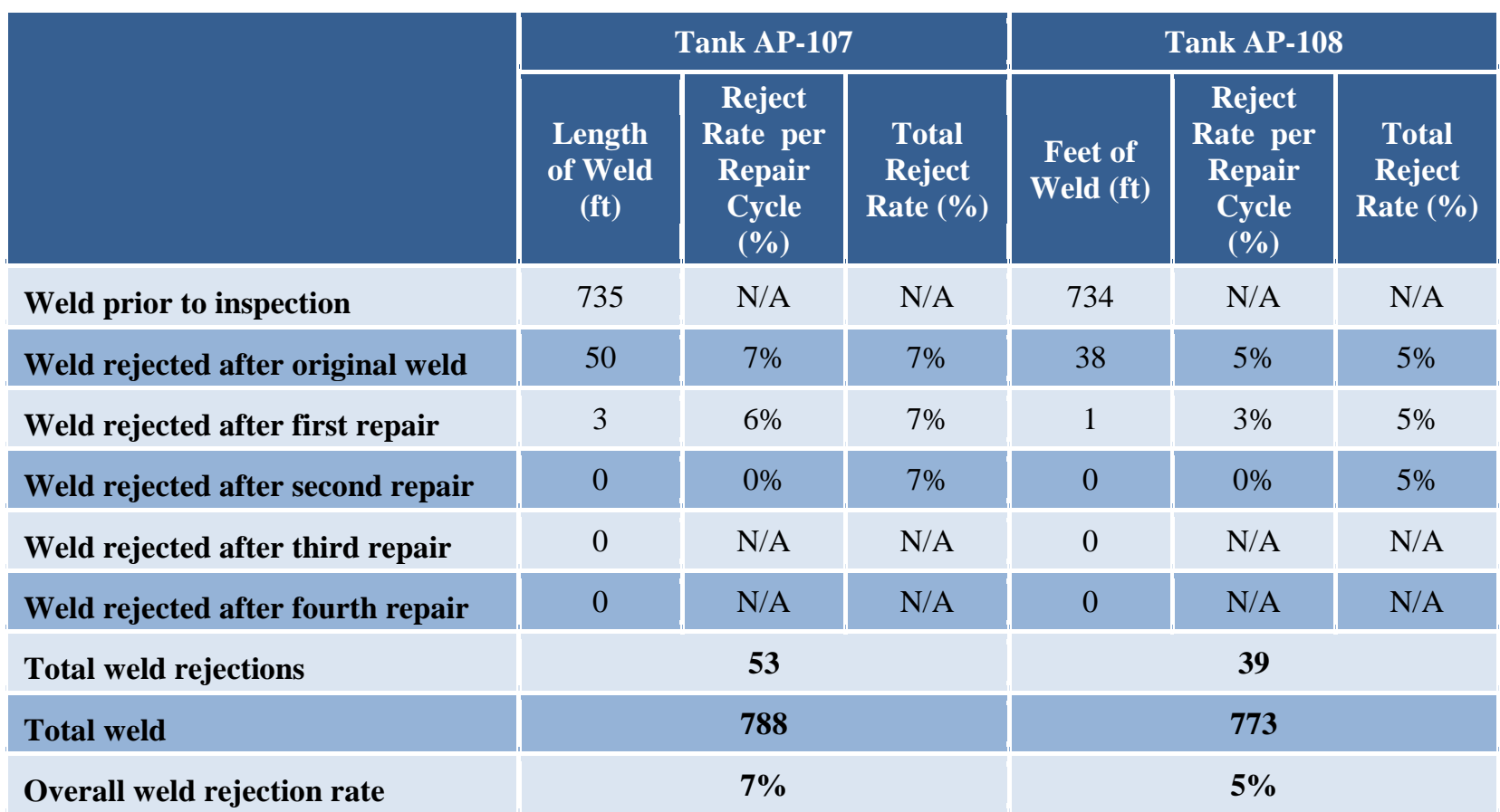


RPP-RPT-55983, Rev. 0

Table 5-7. 241-AY Tank Farm Primary Tank Bottom Welding Success Comparison

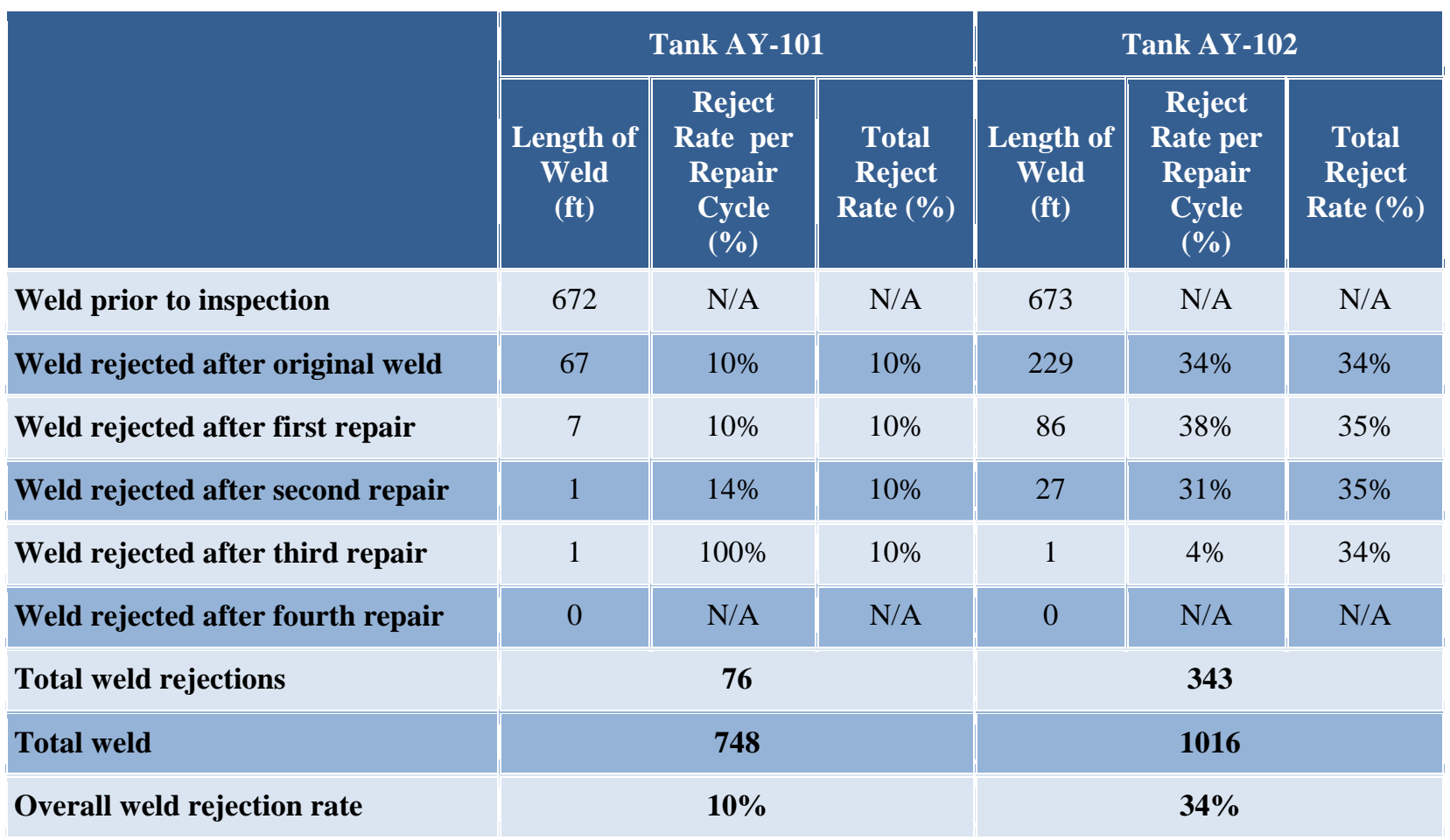

When compared to the 241-AP tank farm, the overall radiographic film rejection rate for tank AY-102 was higher, at 34\%. Weld rejections were a noted issue in RPP-ASMT-53793, leading to repeated re-welding, a contributing factor to bottom flatness out-of-tolerance conditions. The maximum number of times a weld section was repaired during 241-AY tank farm construction was four, with one weld section in tank AY-101 and one weld section in tank AY-102. It should be noted that a weld section is defined within this report as a one foot section. During 241-AP tank farm construction, one weld section was repaired twice in both tank AP-101 and AP-104.

Overall, weld rejection rates do not appear to be a significant issue in the 241-AP tank farm with some of the lowest weld rejection rates seen throughout all of Hanford's double-shell tanks. All initially rejected welds were eventually approved, following acceptable repair.

\subsubsection{Welding Related Nonconformance Reports}

During welding operations, several recurring issues existed. These issues generally fell into the following categories:

- Inadequate preparation of surface prior to weld operations (e.g. rust removal).

- Failure to conduct visual inspection of seams between weld passes.

These issues were documented in various NCRs, outlined in Table 5-8. 
Table 5-8. Nonconformance Reports Related to Welding Quality

\begin{tabular}{|c|c|c|c|}
\hline NCR $\#^{A}$ & Tank & Description & Disposition \\
\hline B-340-33 & AP-106 & $\begin{array}{l}\text { Weld joints on secondary bottom } \\
\text { plates for first weld pass by SMAW } \\
\text { are not being cleaned of rust prior } \\
\text { to welding. Welds and/or tack } \\
\text { welds were made on the BNS } 2,4 \text {, } \\
\text { and } 5 \text { seams on tank A. }\end{array}$ & $\begin{array}{l}\text { Rework - Remove all welds that have } \\
\text { not been properly cleaned. Perform } \\
\text { required preparation and re-weld. (App. } \\
\text { Figure B-1) }\end{array}$ \\
\hline B-340-34 & AP-106 & $\begin{array}{l}\text { Welds BNS } 4 \text { and BNS } 5 \text { were } \\
\text { made on } 10-27-83 \text { with no visual } \\
\text { examination between the second } \\
\text { and third weld pass. }\end{array}$ & $\begin{array}{l}\text { Conditional accept - Review NDE on } \\
\text { welds BNS } 4 \text { and BNS } 5 \text {. If NDE is } \\
\text { acceptable, accept the weld. If NDE } \\
\text { does not pass, repair welds as required } \\
\text { by the C-4 construction specification. } \\
\text { (App. Figure B-2) }\end{array}$ \\
\hline B-340-58 & AP-107 & $\begin{array}{l}\text { Unacceptable surface preparation } \\
\text { (i.e., insufficient rust removal) prior } \\
\text { to field welding first SMAW } \\
\text { overhead pass on BRS seams of } \\
\text { primary tank bottom "J". }\end{array}$ & $\begin{array}{l}\text { Rework - Remove the first SMAW weld } \\
\text { pass (exterior of primary) that was made } \\
\text { on seams specified above that were not } \\
\text { cleaned of rust prior to welding. } \\
\text { Perform the necessary joint preparation, } \\
\text { NDE, and re-weld using approved } \\
\text { procedures. (App. Figure B-3) }\end{array}$ \\
\hline B-340-61 & AP-108 & $\begin{array}{l}2 \text { feet of weld on R-15 at the } \\
\text { intersection of RRS } 2 \text { on tank } 108 \\
\text { dome was welded with no interpass } \\
\text { inspection on two overpass weld } \\
\text { seams. }\end{array}$ & $\begin{array}{l}\text { Conditional accept - Radiograph the } \\
\text { above completed weld joint area per } \\
\text { approved procedures and conditional } \\
\text { acceptance dependent upon acceptance } \\
\text { of radiographs. Alt - Remove weld that } \\
\text { was not inspected and replace per } \\
\text { approved procedures. (App. Figure B-4). }\end{array}$ \\
\hline B-340-62 & AP-107 & $\begin{array}{l}\text { Primary shell, tank } 107, \text { C3V3 area } \\
0 \text { to } 3 \text { and C3V4 area } 0 \text { to } 6 \text { : } \\
\text { Contractor examining personnel did } \\
\text { not visually examine each weld } \\
\text { pass prior to deposit of subsequent } \\
\text { weld passes. }\end{array}$ & $\begin{array}{l}\text { Conditional accept - Acceptance of the } \\
\text { welds will be dependent upon the } \\
\text { radiographic examination of those weld } \\
\text { joints.(App. Figure B-5). }\end{array}$ \\
\hline B-340-63 & AP-108 & $\begin{array}{l}\text { On the interior of primary tank "I" } \\
\text { ( } 108 \text { base), the contractor welded } \\
\text { four ladder brackets approximately } \\
\text { six feet east of the north centerline } \\
\text { without the required tank surface or } \\
\text { attachment surface cleanliness } \\
\text { preparation. }\end{array}$ & $\begin{array}{l}\text { Conditional accept - Acceptable on the } \\
\text { condition that after attachments are no } \\
\text { longer needed, they shall be removed, } \\
\text { the primary tank inner surfaces restored, } \\
\text { and non-destructive testing performed. } \\
\text { Weld joints shall be properly cleaned } \\
\text { before welding.(App. Figure B-6) }\end{array}$ \\
\hline
\end{tabular}


Table 5-8. Nonconformance Reports Related to Welding Quality

\begin{tabular}{|c|c|c|c|}
\hline NCR $\#^{\mathrm{A}}$ & Tank & Description & Disposition \\
\hline B-340-66 & AP-103 & $\begin{array}{l}\text { At primary tank "O", course } 1 \\
\text { vertical weld seams C1V4 and } \\
\text { C1V5: } 2 \text { internal surface } \\
\text { attachments at each seam welded } \\
\text { without prior approval of } \\
\text { government's representative. } \\
\text { (Approval was given for } 4 \\
\text { attachments per seam - } 6 \\
\text { attachments were welded per } \\
\text { seam.) } 6 \text { internal surface } \\
\text { attachments at C1V4 welded } \\
\text { without surface(s) preparation, i.e., } \\
\text { rust not removed. }\end{array}$ & $\begin{array}{l}\text { Rework - Remove attachments and } \\
\text { restore primary tank inner surfaces to } \\
\text { original shape and contour. Perform } \\
\text { non-destructive testing on the attachment } \\
\text { area per specification.(App. Figure B-7) }\end{array}$ \\
\hline B-340-70 & AP-101 & $\begin{array}{l}\text { Tank "E", seam C2V6, Area } 2 \text { to 8: } \\
\text { contractor examining personnel did } \\
\text { not visually examine each weld } \\
\text { pass prior to deposit of coverpass } \\
\text { on the outside of the seam. }\end{array}$ & $\begin{array}{l}\text { Conditional accept - Acceptance of the } \\
\text { welds will be dependent upon the } \\
\text { radiographic examination of that weld } \\
\text { joint.(App. Figure B-8) }\end{array}$ \\
\hline
\end{tabular}

A. NCRs included as App. Figure B-1 through App. Figure B-8.

BNS - Bottom North-South weld seam

BRS - Bottom Round Seam

$\mathrm{C}(\mathrm{x}) \mathrm{V}(\mathrm{y})-\operatorname{Course}(\mathrm{x}) \operatorname{Vertical}(\mathrm{y})$

RRS - Roof Round Seam

SMAW - Shielded Metal Arc Welding

As noted in NCRs B-340-33, 58, 63, and 66, the contractor failed to adequately prepare material surfaces for welding on several occasions. Repetition of this type of issue is of concern due the fact that it often resulted in rework when addressed by NCRs. This rework can contribute to an increase in weld rejection rates and also represents a lack of adherence to procedure by the contractor in this regard. In addition to the NCRs listed in Table 5-8, an interoffice memorandum from Kaiser Engineers Hanford to address the recurrence of this issue.

The memorandum on March 23, 1984, included as App. Figure B-9, stated the following:

"According to NCR B-340-58 we are still experiencing problems in the field with the contractor welding over rust. Also, the Title III inspector informs me that this is a daily trouble area.

Since the contractor has elected to ignore his agreement to clean the plate surfaces in a manner that has been demonstrated to him, it is obvious that corrective action measures are in order. Therefore a letter from KEH QA Manager is being forwarded to JAJ QA Corp. Manager for a corrective action and response. 
Also, in the interest of the assurance of Welding Quality, the KEH QA Department feels that we are bound to initiate quality measures which will bring this problem under control. This measure appears to be that the inspection plan for the Tank Construction Phase be amended to include a hold-point for Title III inspection to verify that plate welding surfaces have been properly cleaned prior to welding. Please initiate a DFC which will institute this measure.

Nonconformance reports B-340-33 and B-340-58 included attached pictures to provide evidence of improperly prepared joint surfaces. These have been included with the attached NCRs in Appendix B as well as below as Figure 5-1, Figure 5-2, and Figure 5-3.

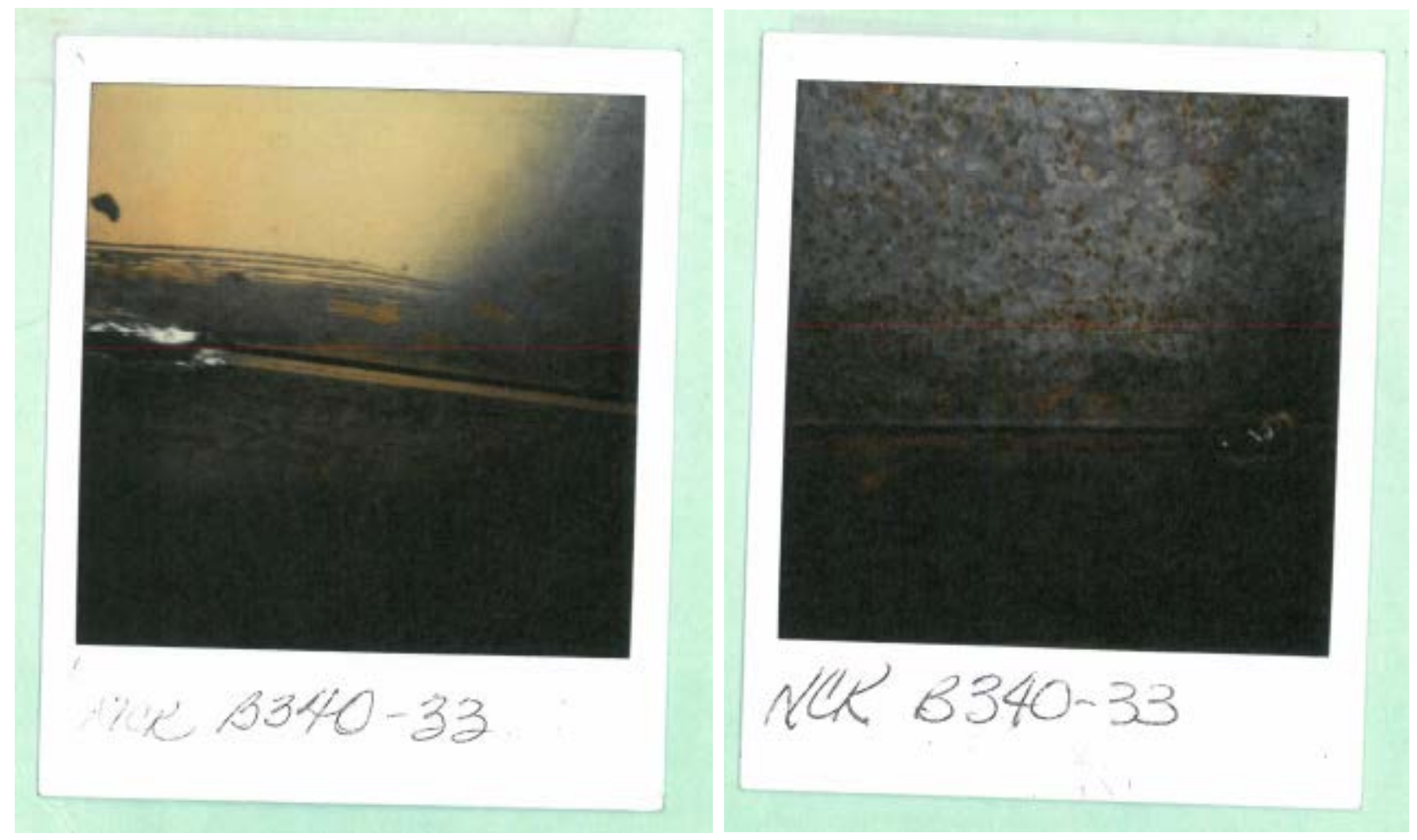

Figure 5-1. NCR B-340-33 Joint Preparation Evidence 
RPP-RPT-55983, Rev. 0

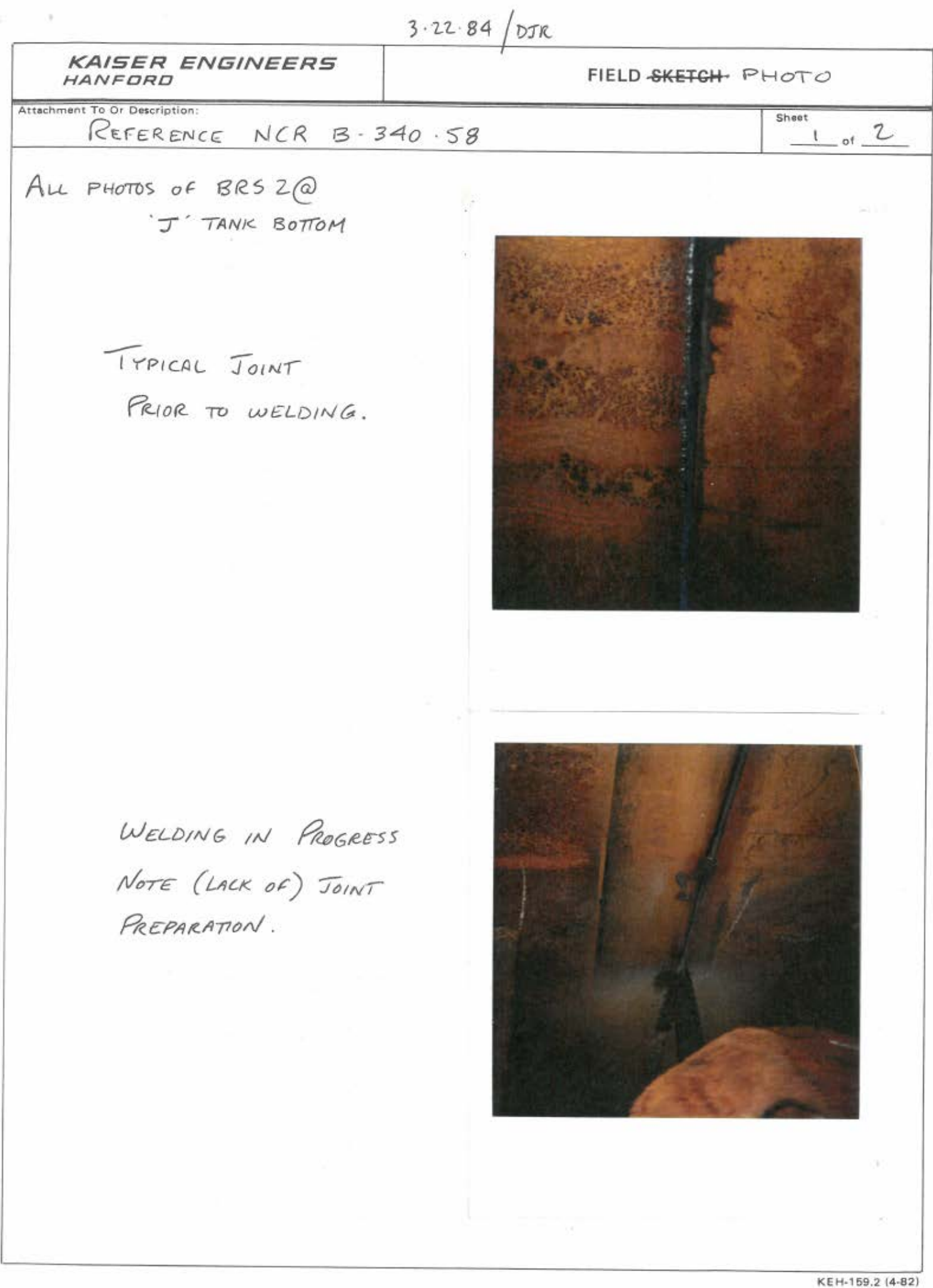

Figure 5-2. NCR B-340-58 Joint Preparation Evidence (1/2) 
RPP-RPT-55983, Rev. 0

3.22 .84 DTR

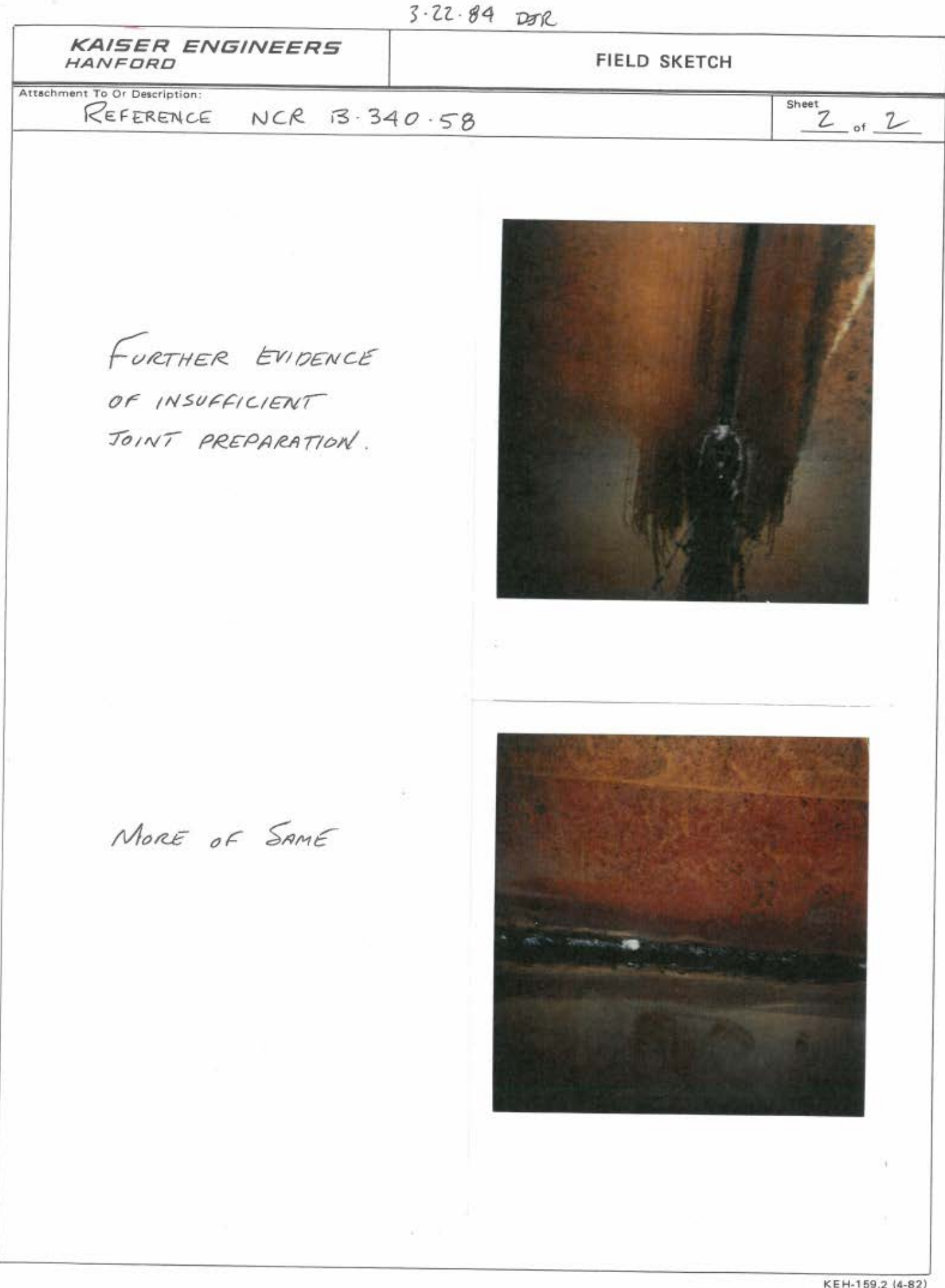

Figure 5-3. NCR B-340-58 Joint Preparation Evidence (2/2) 
As noted in NCRs B-340-34, 61, 62, and 70, the contractor failed to allow for visual inspection between weld passes of a seam on several occasions. Repetition of this type of issue is of concern due the fact that it often resulted in conditional acceptance where future rework would be dependent on flatness tolerances and radiography proving to be acceptable. These actions represent an additional lack of adherence to procedure on the part of the contractor. The included NCRs are the only discovered documentation describing this issue. Ultimately, any issues discovered at a later date through radiography or flatness surveying would have been addressed per approved procedures and the quality of the tank would not have been adversely affected.

\subsection{POST-WELD STRESS RELIEVING}

During stress relief operations in the 241-AP tank farm, there were several temperature-related issues:

- Some thermocouple locations did not reach the required soak temperature of $1000^{\circ} \mathrm{F}$.

- Thermocouple failure.

- 12 hour allowed period for raising temperature from $800^{\circ} \mathrm{F}$ to $1100^{\circ} \mathrm{F}^{4}$ was exceeded.

These issues were documented in the NCRs that are outlined in Table 5-9.

Table 5-9. Post-Weld Stress Relieving Nonconformance Reports

\begin{tabular}{|l|c|l|l|}
\hline NCR \# & Tank & \multicolumn{1}{c|}{ Description } & \multicolumn{1}{c|}{ Disposition } \\
\hline B-340-76 & AP-108 & $\begin{array}{l}\text { The tank } 108 \text { permanent bottom } \\
\text { thermocouples, with few } \\
\text { exceptions, remained lower than the } \\
200^{\circ} \mathrm{F} \text { spread permitted while the } \\
\text { tank was heated from } 800^{\circ} \mathrm{F} \text { to } \\
1050^{\circ} \mathrm{F} \text { as indicated by the } \\
\text { temporary thermocouples. The tank } \\
108 \text { permanent bottom } \\
\text { thermocouples remained below } \\
1000^{\circ} \mathrm{F} \text { during the entire 4 hours } \\
\text { that the temporary thermocouples } \\
\text { remained near } 1050^{\circ} \mathrm{F} .\end{array}$ & $\begin{array}{l}\text { Accept as is - because it met the } \\
\text { alternate code requirement of } 950^{\circ} \mathrm{F} \text { for }\end{array}$ \\
\hline
\end{tabular}

\footnotetext{
${ }^{4}$ The holding(soak) temperature was specified to be $1100^{\circ} \mathrm{F}$ in Specification B-340-C4, however, $1000^{\circ} \mathrm{F}$ was used.
} 
Table 5-9. Post-Weld Stress Relieving Nonconformance Reports

\begin{tabular}{|c|c|c|c|}
\hline NCR \# ${ }^{\mathrm{a}}$ & Tank & Description & Disposition \\
\hline B-340-81 & AP-107 & $\begin{array}{l}\text { The tank } 107 \text { permanent bottom } \\
\text { thermocouples, with few } \\
\text { exceptions, remained lower than the } \\
200^{\circ} \mathrm{F} \text { spread permitted while the } \\
\text { tank was heated from } 800^{\circ} \mathrm{F} \text { to } \\
1050^{\circ} \mathrm{F} \text { as indicated by the } \\
\text { temporary thermocouples. The tank } \\
107 \text { permanent bottom } \\
\text { thermocouples remained below } \\
1000^{\circ} \mathrm{F} \text { during the entire } 3 \text { hours } \\
\text { that the temporary thermocouples } \\
\text { remained near } 1050^{\circ} \mathrm{F} \text {. All } \\
\text { temporary thermocouples installed } \\
\text { on the interior bottom and lower } \\
\text { portion of the exterior bottom } \\
\text { knuckle indicated temperatures that } \\
\text { conformed to the stress relief } \\
\text { procedure. }\end{array}$ & $\begin{array}{l}\text { Accept as is - for future tanks to be } \\
\text { stress relieved, the permanent } \\
\text { thermocouples installed through the } \\
\text { insulating concrete shall not be used to } \\
\text { monitor the primary tank bottom } \\
\text { temperature response during the stress } \\
\text { relief cycle. Temporary thermocouples } \\
\text { shall be used to determine the primary } \\
\text { tank bottom temperatures. The } \\
\text { temporary thermocouple readings } \\
\text { substantiate a successful stress relief } \\
\text { cycle. The permanent thermocouple } \\
\text { readings do not appear to perform as } \\
\text { intended for the stress relief cycle, but } \\
\text { no problems are anticipated when the } \\
\text { tank contains liquid waste. (App. Figure } \\
\text { B-11) }\end{array}$ \\
\hline B-340-88 & AP-102 & $\begin{array}{l}\text { Thermocouples CC, GG, HH, and } \\
\text { JJ failed approximately } 4 \text { hours } \\
\text { before the beginning of the final } \\
\text { soak. This resulted in no } \\
\text { temperature monitoring for fairly } \\
\text { large area of the tank bottom (tank } \\
\text { 102). }\end{array}$ & $\begin{array}{l}\text { Accept as is - The temperature data has } \\
\text { been reviewed for the inside and outside } \\
\text { temporary thermocouples attached to the } \\
\text { primary tank bottom. Before the failure } \\
\text { of the four thermocouples, the } \\
\text { temperature readings were closely } \\
\text { grouped with the other temporary } \\
\text { thermocouples covering the similar tank } \\
\text { bottom areas. After the loss of the four } \\
\text { temporary thermocouples, the remaining } \\
\text { temporary thermocouples indicated that } \\
\text { the primary tank bottom completed a } \\
\text { successful stress relief cycle. After } \\
\text { studying the temperature versus time } \\
\text { data of the adjacent thermocouples, it is } \\
\text { obvious that area of the tank bottom } \\
\text { where the thermocouples were lost also } \\
\text { completed a successful stress relief } \\
\text { cycle. (App. Figure B-12) }\end{array}$ \\
\hline
\end{tabular}


Table 5-9. Post-Weld Stress Relieving Nonconformance Reports

\begin{tabular}{|c|c|c|c|}
\hline NCR $\#^{\mathrm{a}}$ & Tank & Description & Disposition \\
\hline B-340-95 & AP-106 & $\begin{array}{l}\text { Establish stress relief temperatures } \\
\text { of } 1000^{\circ} \mathrm{F} \text { minimum and hold time } \\
\text { of one hour per inch of thickness. } \\
\text { Tank 106: thermocouples II and JJ } \\
\text { did not meet these requirements. }\end{array}$ & $\begin{array}{l}\text { Accept as is - Add } 5 \text { additional } \\
\text { temporary thermocouples per the } \\
\text { attached sketch for the tanks remaining } \\
\text { to be stress relieved. It is obvious from } \\
\text { studying the stress relief cycles for } \\
\text { previous tanks that the primary tank } \\
\text { bottom center is the area recording the } \\
\text { lowest temperatures and the area that } \\
\text { determines the completion of the stress } \\
\text { relief cycle. Additional thermocouple } \\
\text { instrumentation is required in this area to } \\
\text { offer redundancy in case of further } \\
\text { thermocouple failure or erratic } \\
\text { thermocouple data and adequately } \\
\text { monitor the temperature distribution in } \\
\text { that area. (App. Figure B-13) }\end{array}$ \\
\hline B-340-96 & AP-104 & $\begin{array}{l}\text { At tank } 104 \text {, the first recorded } \\
\text { temperature of } 800^{\circ} \mathrm{F} \text { was recorded } \\
\text { at } 8: 20 \text { p.m. on } 9-12-84 \text { and the last } \\
\text { thermocouple reached } 1000^{\circ} \mathrm{F} \text { at } \\
10: 20 \text { a.m. on } 9-13-84 \text {. Therefore } \\
\text { the specified heat-up time was } \\
\text { exceeded by } 2 \text { hours. }\end{array}$ & $\begin{array}{l}\text { Accept as is - The minimum } \\
\text { requirements for stress relief of the tank } \\
\text { have been met. The excessive heat-up } \\
\text { time could affect the yield strength } \\
\text { results which will be addressed at a later } \\
\text { time. (App. Figure B-14) }\end{array}$ \\
\hline
\end{tabular}

a. NCRs included as App. Figure B-10 through App. Figure B-14.

During stress relief of the 241-AP farm tanks, there were several instances of some thermocouples not reaching the required soak temperature of $1000^{\circ} \mathrm{F}$. On two occasions (NCR B-340-76 for tank AP-108 and B-340-81 for tank AP-107), the permanently installed thermocouples embedded in the refractory failed to reach the $1000^{\circ} \mathrm{F}$ soak temperature. However, temperatures of $1050^{\circ} \mathrm{F}$ were recorded from temporary thermocouples, installed between the tank and refractory. Each of these events was "accepted as is" because the temporary thermocouples, in nearly the same location, reached the soak temperature. After tank AP-107 stress relieving, NCR B-340-81 states

"For future tanks to be stress relieved, the permanent thermocouples installed through the insulating concrete shall not be used to monitor the primary tank bottom temperature response during the stress relief cycle."

Two thermocouples did not reach the $1000^{\circ} \mathrm{F}$ soak temperature in tank AP-106. NCR B-340-95 was generated, and the low temperatures were "accepted as is" with the following justification:

"Add 5 additional temporary thermocouples per the attached sketch for the tanks remaining to be stress relieved. It is obvious from studying the stress relief cycles for previous tanks that the primary tank bottom center is the area recording the lowest temperatures and the area that determines the completion of the stress relief cycle. 
Additional thermocouple instrumentation is required in this area to offer redundancy in case of further thermocouple failure or erratic thermocouple data and adequately monitor the temperature distribution in that area."

NCR B-340-88 was generated because four thermocouples in tank AP-102 failed prior to reaching the soak temperature, and there was no temperature monitoring for a large area of the primary tank bottom. The nonconformance was "accepted as is" based on the following:

"The temperature data has been reviewed for the inside and outside temporary thermocouples attached to the primary tank bottom. Before the failure of the four thermocouples, the temperature readings were closely grouped with the other temporary thermocouples covering the similar tank bottom areas. After the loss of the four temporary thermocouples, the remaining temporary thermocouples indicated that the primary tank bottom completed a successful stress relief cycle. After studying the temperature versus time data of the adjacent thermocouples, it is obvious that area of the tank bottom where the thermocouples were lost also completed a successful stress relief cycle."

A failure to increase the tank temperature from $800^{\circ} \mathrm{F}$ to $1000^{\circ} \mathrm{F}$ in the specified 12 hour period (specification B-340-C4, paragraph 3.4.2.4), resulted in NCR B-340-96. The issue was "accepted as is" because, "The minimum requirements for stress relief of the tank have been met." However, the justification also states that "The excessive heat-up time could affect the yield strength results which will be addressed at a later time." There is no reference to any other documents that discuss the effects on the yield strength of the plate material.

The stress relieving issues discussed in this section are judged to be minor compared to the stress relieving issues found in tank AY-102 construction. During tank AY-102 stress relieving, work crews had trouble keeping burners lit for the first three days of attempted stress relieving and intermittently during stress relief. Erratic thermocouples readings along with speculation that thermocouples were reading the temperatures of water from the refractory, rather than the primary tank bottom temperature, lead to large uncertainties in the actual tank bottom temperatures. Tank bottom thermocouples reading as low as $915^{\circ} \mathrm{F}$ were accepted as being $1000^{\circ} \mathrm{F}$ and a 3 hour soak was started. These AY-102 stress relief issues bring into question whether the primary tank was fully stress relieved.

In the 241-AP tank farm, fewer thermocouple problems and no burner issues bring a higher degree of certainty to achieving proper stress relief of the primary tanks.

\subsection{TANK BOTTOM FLATNESS}

Specification B-340-C4, as was identified for other tank farm construction projects, required that primary tank bottoms and secondary liner bottoms could have no root-to-crown slopes (bulges) greater than 3/8 in. per ft. and a maximum root-to-crown height of 3 in. or less.

Only one instance of tank bottom flatness in the 241-AP tank farm was reported. NCR B-340-115 (see App. Figure B-15) was generated for a bulge in the AP-104 primary tank bottom on 11/15/1984 with the following description and disposition: 
“Tank $N$ (104) Survey of the primary tank bottom after stress relief showed two areas were out of the 3/8" per foot tolerance. The contractor put dead weight on the two areas. Survey was then performed. The new survey showed the two areas that were out of tolerance were now acceptable. However, an area on BEW4 adjacent to the centering post was then found 1/8" out of tolerance per foot for three feet.

Disposition: Accept as is

Justification: The 1/2"/ft slope (3/8" + 1/8”) exceeds the specification requirements but falls within the 3/4"/ft limit substantiated in SAM-76-1 report by Battelle Pacific Northwest Laboratory, titles 'Analysis of Stresses Due to the Flattening of Bumps in the Bottom and Knuckle Regions of Million Gallon Waste Storage Tanks.'

Any repair procedure of the primary tank bottom is not recommended to insure maximum integrity of that boundary be maintained."

No further information was discovered regarding tank bottom bulging in the 241-AP tank farm.

\subsection{REFRACTORY}

On February 29, 1984, NCR B-340-56 (see App. Figure B-16) was generated because of a lack of refractory protection. The NCR has the following description and disposition:

“Castable refractory placement at tank bottom C (108) quadrants 2 and 4, $2^{\text {nd }}$ lift, on 2/28/1984 was not protected during curing to minimize the formation of plastic shrinkage cracks. Impervious sheet plastic was supported approximately 1 to 3 feet above the refractory placement, however, the cover was open on a majority of the perimeter allowing the wind to blow across the refractory placement. Heaters were situated to blow between cover and refractory placement. Excessive plastic shrinkage cracks developed.

Disposition: Fill all cracks 1/16” wide or greater to a depth of 3/4” min. with plastic refractory material. Additional precautions should be taken to prevent the formation of plastic shrinkage cracks on future pours.

Justification: During stress relief the refractory material will expand and fill a 1/16" crack. The maximum depth of cover over the air pipe is 3/4" per specification."

Protection of refractory is specified in Section 3.2 of Specification B-340-C4 and provides the following:

“3.2.1 Adequately protect the refractory from physical damage due to mechanical injury, material breakdown at temperatures below $40 \mathrm{~F}$, and material degeneration at temperatures above $90 \mathrm{~F}$.

3.2.1.1 Protect the refractory surface from the injurious action of rain.

3.2.1.2 When the atmospheric temperature is below $40 \mathrm{~F}$, the air in contact with the surface of the refractory shall be maintained at a temperature not less than $50 \mathrm{~F}$ 
for the full curing period stipulated by the refractory manufacturer. A protective enclosure of sheet plastic, plywood, or other approved construction shall be provided to maintain temperature control. The method of heating the enclosure shall be in accordance with the approved submittals. Supplemental protection from freezing after the full curing period shall be provided in compliance with the manufacturer's recommendations.

3.2.1.3 When the atmospheric temperature is above $90 \mathrm{~F}$, extra care shall be taken to prevent rapid drying of the newly placed refractory. The fresh refractory shall be shaded as soon as possible after depositing and curing procedures shall be started as soon as the refractory surface is sufficiently hard to permit application without damage to the surface.

3.2.1.4 Allow no loads on the refractory surface until compressive tests indicate the required compressive strength has been attained."

\subsection{ISSUES UNIQUE TO 241-AP TANK FARM}

\subsubsection{Steel Plate Damages}

During tank and liner inspections, many instances of plate damage were discovered, including laminations, scabs, gouges, or pits. In most cases, these issues were caught during inspection by American Bridge, resulting in approximately 83 NCRs (Integrated Data Management System (IDMS), Queried 2/5/2014, [241-AP Tank Farm Steel Plate Damage NCRs], http://idmsweb.rl.gov/idms/livelink.exe). In all cases these were repaired per approved methods.

In one instance from July 30, 1984, material was discovered in the AP-101 and AP-104 primary tank bottom that was suspected to be reject material. Following investigation and communication with the vendor, it was determined that what were thought to be laminations in the material were just scabs. All material with sharp gouges or scratches less than 1/32-in. deep was repaired by minor grinding (not to exceed 1/32-in.) and accepted for use. For gouges and scratched deeper than 1/32-in., imperfections were filled with weld metal and inspected per Specification B-340-C4. This event was documented via NCR B-340-85 (App. Figure B-17) and described as follows:

“2a. Per Hogan Manufacturing, Inc. Nonconformance Reports No. 197 and No. 200, 1/2 inch material with control numbers $\mathrm{H}-183$ and $\mathrm{H}-186$ are reject material and are found in 101 primary bottom and 104 primary bottom."

This NCR description is followed up by the following instructions:

"Provide evidence of original documentation showing material acceptability per project requirements. If such documentation is not available, repair or replace reject material with acceptable materials." 
Communication from Hogan Manufacturing to American Bridge (App. Figure B-18) on the same day of the NCR, July 30, 1984, explained the use of the material and the steps taken to achieve acceptability. It states the following:

"Further review of the subject plates indicated that what was perceived to be laminations were in fact scabs. These scabs were repaired by minor grinding by Hogan Mfg. in lieu of returning to vendor, Kaiser Steel. Pits were acceptable in existing condition.

This was done in an effort to reduce overall costs and shop requirements of subject material. This determination was made after the NCR had been returned from the Project Manager to the Q.C Department.

Overall, steel plate damage of various kinds was commonplace during 241-AP tank farm construction. All plates were repaired using an Engineering-approved repair procedure. Given the information discovered, adequate attention and disposition was given to ensure plate quality and tank integrity.

\subsubsection{Tank Dome Distortions}

Tank AP-107 was the second in the 241-AP tank farm to be post-weld stress relieved beginning on July 19, 1984. After stress relieving, it was noted in NCR B-340-89 (see App. Figure B-19) that the AP-107 dome exhibited a drop of up to $5 \mathrm{in}$. around riser $\# 5$ at $180^{\circ}$ and $270^{\circ}$. To resolve the dome deformations, additional anchor studs were added per NCR attachment.

NCR B-340-98, as seen in App. Figure B-20, notes a similar issue with tank AP-104. Tank AP104 was stress relieved on September 12, 1984, and was the sixth tank to be stress relieved. NCR B-340-98 says that the dome dropped 3 to 4 in. around riser \#5, and 2 in. around riser \#12 and riser \#27. Additional anchor studs were utilized to provide an additional margin of safety for stress reduction in welds around the risers.

Tank AP-103 was stress relieved directly after tank AP-104, followed by tank AP-105. NCR B-340-102 and B-340-105 (see App. Figure B-21 and App. Figure B-22, respectively), for tanks AP-103 and AP-105 respectively, documented 2 to 3 in. drops in the dome plate around riser \#5. Both cases were "accepted as is" and additional anchor studs were added for safety.

Similar issues took place after stress relieving tank AW-101 during 241-AW tank farm construction, as noted in RPP-RPT-55981, 241-AW Tank Farm Construction Extent of Condition Review for Tank Integrity. Tank AW-101 saw significant distortions around the risers used for the stress relief burners after reaching a soaking temperature of $1100^{\circ} \mathrm{F}$. The soak temperature was reduced to $1000^{\circ} \mathrm{F}$ for the rest of the $241-\mathrm{AW}$ tank farm tanks.

\subsubsection{Tank Foundation}

During tank foundation concrete placement, there were several recurring structural integrity, surface finish, and patching-related issues: 
- Concrete deposited in large quantities, and vibrators used to transport concrete between forms.

- Slow rate of concrete placement.

- Bonding grout placed over curing compound.

- Repair patches not protected from freezing temperatures.

These issues, along with other tank foundation related issues, were documented in the NCRs that are outlined in Table 5-10.

Table 5-10. Tank Foundation Nonconformance Reports

\begin{tabular}{|c|c|c|c|}
\hline NCR $\#^{\mathbf{A}}$ & Tank & Description & Disposition \\
\hline B-340-13 & AP-102 & $\begin{array}{l}\text { Perimeter formwork installed for tank } \\
\text { foundation D (102) did not withstand } \\
\text { the lateral loading. Inadequate form } \\
\text { braces gave way during concrete } \\
\text { placement. }\end{array}$ & $\begin{array}{l}\text { Accept as is - The contractor shall } \\
\text { outline how he plans to correct the } \\
\text { formwork failure problem and } \\
\text { specify his plan for adhering to the } \\
\text { contract specifications prior to } \\
\text { placement of the next foundation. } \\
\text { Slippage of forms did not affect the } \\
\text { structural integrity of the slab. } \\
\text { (App. Figure B-23) }\end{array}$ \\
\hline B-340-14 & AP-102 & $\begin{array}{l}\text { A layer of concrete placed in the } \\
\text { north side of tank } 102 \text { foundation } \\
\text { hardened to the point it was not } \\
\text { plastic prior to placing the subsequent } \\
\text { layer. }\end{array}$ & $\begin{array}{l}\text { Core drill slab with 4” diameter bit } \\
\text { to depth of } 16 \text { ” for 2' thick slab and } \\
24 \text { ” for 2'8” thick slab at locations } \\
\text { determined in field and referenced } \\
\text { on attachment \#1. Evaluation of } \\
\text { cores will determine disposition of } \\
\text { this NCR. Ref. NCR B-340-24. } \\
\text { (App. Figure B-24) }\end{array}$ \\
\hline
\end{tabular}


Table 5-10. Tank Foundation Nonconformance Reports

\begin{tabular}{|c|c|c|c|}
\hline $\mathbf{N C R} \#^{\mathbf{A}}$ & Tank & Description & Disposition \\
\hline B-340-15 & AP-102 & $\begin{array}{l}\text { Concrete pour of tank foundation D } \\
\text { (102) on 9-9-83. Internal vibrators } \\
\text { were operated by inexperienced } \\
\text { workmen. At several locations, } \\
\text { concrete was deposited in large } \\
\text { quantities in one area and vibrators } \\
\text { were used to transport concrete within } \\
\text { the forms. Some concrete received } \\
\text { excessive vibration and others not } \\
\text { enough. Inadequate vibration was } \\
\text { performed around embeds and forms, } \\
\text { causing air voids and stone pockets. } \\
\text { The embedded angles installed along } \\
\text { the leak detection drain have voids } \\
\text { under the angle at several locations. } \\
\text { The floated finish required for tank } \\
\text { foundation } 102 \text { does not have a } \\
\text { uniform sandy texture. At various } \\
\text { locations, the surface is irregular and } \\
\text { has air voids and visible surface } \\
\text { aggregate. }\end{array}$ & $\begin{array}{l}\text { Rework - Repair defect areas to } \\
\text { contract specification requirements. } \\
\text { Contractor shall take appropriate } \\
\text { action to insure that concrete } \\
\text { placement and finishing is } \\
\text { performed according to contract } \\
\text { specification. Method of patching } \\
\text { to be approved by the government } \\
\text { representative prior to patching. } \\
\text { (App. Figure B-25) }\end{array}$ \\
\hline B-340-17 & AP-101 & $\begin{array}{l}\text { At several large areas within the slab, } \\
\text { the rate of concrete placement was } \\
\text { not such that the concrete to be } \\
\text { integrated with fresh concrete was } \\
\text { still plastic. Excessive over-vibration } \\
\text { was used to re-establish plasticity of } \\
\text { the hardening concrete prior to } \\
\text { placement and integration with the } \\
\text { subsequent layer of concrete. }\end{array}$ & $\begin{array}{l}\text { Accept as is - The contractor } \\
\text { should take precautions to prevent } \\
\text { the formation of cold joints by } \\
\text { maintaining adequate rate of } \\
\text { concrete placement. Re-vibration is } \\
\text { acceptable as long as running the } \\
\text { vibrator will sink of its own weight } \\
\text { into the concrete and liquefy it } \\
\text { momentarily. (App. Figure B-26) }\end{array}$ \\
\hline B-340-21 & AP-108 & $\begin{array}{l}\text { The floated finish required for tank } \\
\text { foundation C (108) does not have a } \\
\text { uniform sandy texture. At various } \\
\text { locations, the surface is irregular and } \\
\text { has air voids and visible surface } \\
\text { aggregate. The contractor was } \\
\text { repeatedly notified about the } \\
\text { condition of the finish in sufficient } \\
\text { time to correct the problem. }\end{array}$ & $\begin{array}{l}\text { Rework - Repair defect areas to } \\
\text { contract specification requirements. } \\
\text { Contractor Shall take appropriate } \\
\text { action to insure that concrete } \\
\text { placement and finishing is } \\
\text { performed according to contractor } \\
\text { specification. Method of patching } \\
\text { to be approved by the government } \\
\text { rep prior to patching. (App. Figure } \\
\text { B-27) }\end{array}$ \\
\hline
\end{tabular}


Table 5-10. Tank Foundation Nonconformance Reports

\begin{tabular}{|c|c|c|c|}
\hline $\mathrm{NCR} \#^{\mathrm{A}}$ & Tank & Description & Disposition \\
\hline B-340-23 & AP-108 & $\begin{array}{l}\text { Concrete pour of tank foundation C } \\
\text { (108) on 8-30-83. At several } \\
\text { locations, concrete was deposited in } \\
\text { large quantities in one area and } \\
\text { vibrators were used to transport } \\
\text { concrete within the forms. In several } \\
\text { instances, this resulted in excessive } \\
\text { vibration and segregation. }\end{array}$ & $\begin{array}{l}\text { Accept as is - Contractor shall } \\
\text { provide means of placing concrete } \\
\text { at its final location. Concrete shall } \\
\text { be moved by vibration no further } \\
\text { thank } 2 \text { to } 3 \mathrm{ft} \text {. to prevent } \\
\text { segregation of aggregate. Repair } \\
\text { any defects caused by segregation } \\
\text { to contract specification } \\
\text { requirements. (App. Figure B-28) }\end{array}$ \\
\hline B-340-24 & AP-102 & $\begin{array}{l}\text { Upon evaluation of concrete cores } \\
\text { taken from tank D (102) foundation, a } \\
\text { cold joint was indicated at core \# 3, } \\
11-1 / 2 \text { " from the surface and core \# 9, } \\
12-1 / 2 \text { " from the surface. }\end{array}$ & $\begin{array}{l}\text { Rework - Locate all cores with } \\
\text { angle and distance from center of } \\
\text { tank. Identify rebar cut when } \\
\text { coring, radial or circumferential for } \\
\text { each core hole. Repair all core } \\
\text { holes by filling with non-shrink } \\
\text { grout. Remove cold joint in the area } \\
\text { around cores \# } 3 \text { and } 9 \text {. The extent } \\
\text { of the cold joint will be determined } \\
\text { by the government rep. during } \\
\text { rework. There is no evidence of } \\
\text { rock pockets in cores taken outside } \\
\text { the cold joint area. A few large } \\
\text { (1/2” dia. Max) air bubbles were } \\
\text { seen, but not of a frequency to } \\
\text { affect the structural integrity of the } \\
\text { concrete tank foundation. (App. } \\
\text { Figure B-29) }\end{array}$ \\
\hline B-340-29 & AP-108 & $\begin{array}{l}\text { Daraweld-C bonding grout was } \\
\text { placed over curing compound during } \\
\text { repair at tank bases B (103) and C } \\
\text { (108), In telephone conversations } \\
\text { with the manufacturer of Daraweld-C } \\
\text { and A C Horn, the manufacturer of } \\
\text { the curing compound, it was stressed } \\
\text { that the curing compound must be } \\
\text { removed to obtain the desired bond. }\end{array}$ & $\begin{array}{l}\text { Rework - Remove all patches } \\
\text { applied over curing compound. } \\
\text { Prior to applying new patches, } \\
\text { remove all traces of curing } \\
\text { compound in accordance with the } \\
\text { manufacturer's instructions. The } \\
\text { patch and concrete must bond } \\
\text { together to produce an acceptable } \\
\text { patch. (App. Figure B-30) }\end{array}$ \\
\hline
\end{tabular}


Table 5-10. Tank Foundation Nonconformance Reports

\begin{tabular}{|c|c|c|c|}
\hline NCR \# A $^{\mathrm{A}}$ & Tank & Description & Disposition \\
\hline B-340-30 & $\begin{array}{l}\text { AP-101, } \\
\text { AP-103, } \\
\text { AP-104, } \\
\text { AP-108 }\end{array}$ & $\begin{array}{l}\text { Repair patching on the surface of tank } \\
\text { bases } 101, B \text { (103), } 104 \text { and C (108) } \\
\text { have areas that are soft and indicate } \\
\text { lack of strength. Areas at tank base C } \\
\text { (108) have excessive cracking in the } \\
\text { repair patch. }\end{array}$ & $\begin{array}{l}\text { Rework - Determine the cause of } \\
\text { the low strength patching material } \\
\text { and excessive cracking. Verify } \\
\text { through the manufacturer of the } \\
\text { bonding agent that materials and } \\
\text { methods used will not be } \\
\text { detrimental to the development of } \\
\text { bond and compressive strength. } \\
\text { Remove unsound material, etch and } \\
\text { clean surface, and apply patching } \\
\text { material, in accordance with the } \\
\text { manufacturer's instructions. (App. } \\
\text { Figure B-31) }\end{array}$ \\
\hline B-340-40 & AP-105 & $\begin{array}{l}\text { Repair patches placed in the drain } \\
\text { slots of tank base "B" (105) on } \\
\text { 11/29/1983 were not protected from } \\
\text { freezing temperature. Temperatures } \\
\text { as low as } 26^{\circ} \mathrm{F} \text { were recorded at } \\
\text { approximately } 7: 30 \text { a.m., } 11 / 30 / 83 \text {. }\end{array}$ & $\begin{array}{l}\text { Conditional accept - Remove and } \\
\text { replace all patched areas exhibiting } \\
\text { lack of strength or bond to the } \\
\text { concrete base after } 350^{\circ} \mathrm{F} \text { days }{ }^{\mathrm{B}} \text {. } \\
\text { Re-evaluate patched areas prior to } \\
\text { placement of secondary tank } \\
\text { bottom. (App. Figure B-32) }\end{array}$ \\
\hline B-340-42 & $\begin{array}{l}\text { AP-101, } \\
\text { AP-102, } \\
\text { AP-104 }\end{array}$ & $\begin{array}{l}\text { Repair patches placed on tank base } \\
101,104 \text {, and } 102 \text { have not been } \\
\text { adequately protected from cold } \\
\text { weather. Repair patches on tank base } \\
101 \text { on } 11 / 29 / 83 \text { and } 12 / 2 / 83 \text { had } \\
\text { recorded overnight and morning } \\
\text { temperatures ranging from } 31^{\circ} \mathrm{F} \text { to } \\
36^{\circ} \mathrm{F} \text { on } 5 \text { consecutive days after } \\
\text { placement. Repair patches on tank } \\
\text { base } 104 \text { placed on } 12 / 2 / 83 \text { ranged } \\
\text { from } 33^{\circ} \mathrm{F} \text { to } 36^{\circ} \mathrm{F} \text { for } 3 \text { consecutive } \\
\text { days after placement. Repair patches } \\
\text { placed on tank base } 102 \text { on } 12 / 7 / 83 \\
\text { ranged from } 36^{\circ} \mathrm{F} \text { to } 37^{\circ} \mathrm{F} \text { the first } \\
\text { morning after placement. }- \text { until the } \\
\text { patching has cured the } 350^{\circ} \mathrm{F} \text { days }{ }^{\mathrm{B}} \text {. }\end{array}$ & $\begin{array}{l}\text { Conditional accept }- \text { Provide } 40^{\circ} \mathrm{F} \\
\text { min temperature of the environment } \\
\text { for } 350^{\circ} \mathrm{F} \text { days }{ }^{\mathrm{B}} \text { required by the } \\
\text { bonding grout manufacturer. } \\
\text { Remove and replace all patched } \\
\text { areas exhibiting lack of strength or } \\
\text { bond to the original concrete base } \\
\text { after } 350^{\circ} \mathrm{F} \text { days }{ }^{\mathrm{B}} \text {. Re-evaluate all } \\
\text { patched areas prior to placement of } \\
\text { secondary tank bottom. The } \\
\text { contractor shall provide evidence } \\
\text { that he can provide an environment } \\
\text { capable of maintaining a } \geq 40^{\circ} \mathrm{F} \\
\text { temperature before and after } \\
\text { placement of any patching, prior to } \\
\text { patching continuing. The } \\
\text { foundation shall be heated to } \\
\text { maintain a } \geq 40^{\circ} \mathrm{F} \text { temperature. } \\
\text { (App. Figure B-33) }\end{array}$ \\
\hline
\end{tabular}


RPP-RPT-55983, Rev. 0

Table 5-10. Tank Foundation Nonconformance Reports

\begin{tabular}{|c|c|c|c|}
\hline $\mathbf{N C R} \#^{\mathbf{A}}$ & Tank & Description & Disposition \\
\hline B-340-43 & AP-102 & $\begin{array}{l}\text { Repair patches placed on } 12-19-83 \text { at } \\
\text { tank base "D” (102) have not been } \\
\text { adequately protected from cold } \\
\text { weather. Morning temperatures on } \\
12-22-83 \text { revealed patch temperatures } \\
\text { ranging from } 28^{\circ} \mathrm{F} \text { to } 34^{\circ} \mathrm{F} \text {. Ice } \\
\text { formations were apparent on several } \\
\text { patches. The ambient overnight low } \\
\text { within the heated shelter was } 25^{\circ} \mathrm{F} \text {. - } \\
\text { Conditional accept: Provide } 40^{\circ} \mathrm{F} \text { min } \\
\text { temperature of the environment for } \\
350^{\circ} \mathrm{F} \text { days }{ }^{\mathrm{B}} \text { required by the bonding } \\
\text { grout manufacturer. }\end{array}$ & $\begin{array}{l}\text { Rework - Remove and replace all } \\
\text { patched areas exhibiting lack of } \\
\text { strength or bond to the original } \\
\text { concrete base after } 350^{\circ} \mathrm{F} \text { days }{ }^{\mathrm{B}} \text {. } \\
\text { Re-evaluate patched areas prior to } \\
\text { placement of secondary tank } \\
\text { bottom. Areas of low strength or } \\
\text { bond should be reworked. The } \\
\text { contractor shall provide evidence } \\
\text { that he can provide an environment } \\
\text { capable of maintaining a minimum } \\
\text { temperature of } 40^{\circ} \mathrm{F} \text { before and } \\
\text { after placement of any patching, } \\
\text { prior to patching continuing. The } \\
\text { foundation shall be heated for a } \\
\text { time interval adequate to maintain a } \\
\text { minimum temperature of } 40^{\circ} \mathrm{F} \\
\text { during placement of the patching } \\
\text { material. After placement of } \\
\text { patching, the environment shall be } \\
\text { maintained at } 40^{\circ} \mathrm{F} \text { min for } 350^{\circ} \mathrm{F} \\
\text { days }{ }^{\mathrm{B}} \text {. (App. Figure B-34) }\end{array}$ \\
\hline B-340-46 & AP-101 & $\begin{array}{l}\text { At tank foundation } 101 \text {, there are } 11 \\
\text { locations on the top of the concrete } \\
\text { foundation that are out of tolerance } \\
\text { by } 0.01 \text { of a foot ( } 1 / 8 \text { inch). At tank } \\
\text { foundation } 101 \text {, there are } 20 \text { areas } \\
\text { that do not meet the required flatness } \\
\text { tolerances. These areas exceed either } \\
\text { or both the } 1 / 4 \text { inch in } 10 \text { foot or } 1 / 8 \\
\text { inch in } 2 \text { foot flatness tolerance. }\end{array}$ & $\begin{array}{l}\text { Conditional accept - Take } \\
\text { corrective measures to assure } \\
\text { primary tank bottom will be at } \\
\text { specified elevation within specified } \\
\text { tolerances. The slight deviation } \\
\text { from specified elevation will not } \\
\text { impact the design requirements for } \\
\text { the tank. Repair - grind surface or } \\
\text { patch per approved repair } \\
\text { procedures to meet required } \\
\text { flatness tolerances. Flatness } \\
\text { requirements for the tank bottoms } \\
\text { must be maintained. (App. Figure } \\
\text { B-35) }\end{array}$ \\
\hline B-340-47 & AP-105 & $\begin{array}{l}\text { Reference B-340- } 40 \text {. Repair patches } \\
\text { placed in the drain slots of tank base } \\
105 \text { on } 11 / 29 / 83 \text { were not protected } \\
\text { from freezing temperature. } \\
\text { Temperatures as low as } 26^{\circ} \mathrm{F} \text { were } \\
\text { recorded at approximately } 7: 30 \text { a.m., } \\
11 / 30 / 83 \text {. Re-evaluation of patches } \\
\text { was performed on } 1 / 9 / 84 \text { and } 1 / 11 / 84 \text {. } \\
\text { At } 2 \text { locations, the patches are soft } \\
\text { and lack strength. }\end{array}$ & $\begin{array}{l}\text { Rework - Replace patch \#1 prior to } \\
\text { placement of the secondary tank } \\
\text { bottom...a minimum strength of } \\
500 \text { psi shall be attained. Accept as } \\
\text { is - The patch \#2 in the immediate } \\
\text { area occupies about } 35 \% \text { of the } \\
\text { surface area. This would not block } \\
\text { the trench if it became detached. } \\
\text { (App. Figure B-36) }\end{array}$ \\
\hline
\end{tabular}


RPP-RPT-55983, Rev. 0

Table 5-10. Tank Foundation Nonconformance Reports

\begin{tabular}{|c|c|c|c|}
\hline $\mathbf{N C R} \#^{\mathbf{A}}$ & Tank & Description & Disposition \\
\hline B-340-49 & AP-102 & $\begin{array}{l}\text { Repair patches placed on tank base } \\
\text { "D” }(102) \text { on } 1 / 13 / 84,1 / 16 / 84 \text {, and } \\
1 / 17 / 84 \text { have not been adequately } \\
\text { protected from cold weather. On } \\
1 / 19 / 84 \text {, at approximately } 9: 30 \text { a.m., } \\
\text { recorded patch temperatures ranged } \\
\text { from } 33^{\circ} \mathrm{F} \text { to } 39^{\circ} \mathrm{F} \text {. Morning } \\
\text { temperatures were again below } 40^{\circ} \mathrm{F} \\
\text { for these repaired areas on } 1 / 20 / 84 \text {. }\end{array}$ & $\begin{array}{l}\text { Condition accept - Remove and } \\
\text { replace all patched areas exhibiting } \\
\text { lack of strength or bond to the } \\
\text { original concrete base after } 350^{\circ} \mathrm{F} \\
\text { days }^{\mathrm{B}} \text {. Re-evaluate all patched areas } \\
\text { prior to placement of secondary } \\
\text { tank bottom. Areas of low strength } \\
\text { or poor bond shall be reworked. } \\
\text { (App. Figure B-37) }\end{array}$ \\
\hline B-340-51 & AP-102 & $\begin{array}{l}\text { At tank foundation “D” (102), the } \\
\text { elevation of the finished drain slots } \\
\text { vary from the allowable tolerance. }\end{array}$ & $\begin{array}{l}\text { Accept as is - all slots have } \\
\text { adequate cross sectional areas and } \\
\text { alternate directions of flow to } \\
\text { provide adequate leak detection } \\
\text { drainage in event of leakage. (App. } \\
\text { Figure B-38) }\end{array}$ \\
\hline B-340-53 & AP-102 & $\begin{array}{l}\text { Concrete placed on 2/1/84 for pour } \\
\text { back of cold joint on tank base } 102 \\
\text { [NCR B-340-14 and B-340-24] was a } \\
6 \text { ” slump. Approximately one cubic } \\
\text { yard of concrete was placed. }\end{array}$ & $\begin{array}{l}\text { Conditional accept - acceptance } \\
\text { shall be based on break strength of } \\
\text { cylinders at } 28 \text { days. (App. Figure } \\
\text { B-39) }\end{array}$ \\
\hline \multicolumn{4}{|c|}{$\begin{array}{l}\text { A. NCRs included as App. Figure B-23 through App. Figure B-39. } \\
\text { B. "Degree-Days" (e.g. } 350^{\circ} \mathrm{F} \text { days) is a time-temperature factor used to estimate the in-place strength of } \\
\text { concrete to allow the continuance of construction activities such as termination of cold weather protection } \\
\text { (see ASTM C1074, Standard Practice for Estimating Concrete Strength by the Maturity Method, for details). }\end{array}$} \\
\hline
\end{tabular}

The NCRs listed in Table 5-10, have several common issues along with a couple of minor unique issues.

It is noted in NCR B-340-13 (see App. Figure B-23) that perimeter formwork installed for tank AP-102 foundation, did not withstand the lateral loading. The cause was determined to be inadequate braces. Although it states that "Slippage of forms did not affect the structural integrity of the slab", the contractor was still required to outline a plan to correct the formwork failure prior to concrete placement in future tank foundations.

Three NCRs are related to slow concrete placement, where concrete was placed at a rate that allowed hardening of the concrete and the possible formation of cold joints. NCR B-340-14 (see App. Figure B-24) requires core drills of the tank AP-102 foundation in the location of possible cold joint formations, and references NCR B-340-24 for disposition, see App. Figure B-29.

NCR B-340-24 evaluates the concrete cores taken for NCR B-340-14 and notes that some repair was required in these locations due to cold joints. Approximately 1 cubic yard of concrete was used for pour back in these repair areas. The concrete used had a slump of 6 in., which was greater than the 4 in. maximum slump stated in Specification B-340-C3. The high slump was accepted based on the 28-day concrete cylinder breaks (NCR B-340-53). In NCR B-340-17 (see App. Figure B-26), it is noted that excessive vibration was used to re-establish plasticity due to 
slow concrete placement for tank AP-101 foundation. Over-vibration was accepted as is, and the contractor was cautioned about over-vibration.

On two separate occasions (NCR B-340-15, and B-340-23 for tank AP-102 foundation and tank AP-108 foundation, respectively), concrete was deposited in large quantities in one area within the forms. Vibrators were used to transport concrete within the forms. Some concrete received over-vibration while some did not receive enough vibration. In NCR B-340-15 (see App. Figure B-25), tank foundation AP-102 received inadequate vibration around embeds and forms, causing air voids and stone pockets. The floated finish was irregular and had air voids and visible surface aggregate. The defect areas were repaired by an approved patching method. In NCR B340-23 (see App. Figure B-28), Concrete placed for tank foundation AP-108 received excessive vibration in an attempt to transport concrete within the forms. The excessive vibration resulted in segregation of the concrete. Limits were then set on the distance that concrete could be transported, and any defects caused by segregation were repaired.

There were two instances of out-of-tolerance tank foundations. NCR B-340-46 (see App. Figure B-35) notes that tank AP-101 foundation had 11 locations on top of the concrete foundation that are out of tolerance by 1/8-in., and 20 areas that did not meet the required flatness tolerances. Grinding and patching was used to bring the tank foundation within tolerances specified in B340-C3. In tank AP-102, the variance of the finished drain slots from the allowable tolerance, prompted NCR B-340-51 (see App. Figure B-38). The slots were accepted as is based on the following justification:

"All slots have adequate cross section areas and alternate directions of flow to provide adequate leak detection drainage in event of leakage."

Several concrete patching-related NCRs were generated during construction of the 241-AP tank farm tank foundations. Initial concrete patching failed because the bonding grout used to patch the concrete was placed over the curing compound. The curing compound does not allow the bonding grout to bond to the original concrete. The patch was removed, curing compound was cleaned off, and bonding grout was reapplied. Some initial patching was soft, and showed excessive cracking. The patch was removed, and the bonding grout manufacturer was consulted for re-application of the grout. Most of the patching-related NCRs were due to improper protection of the patch during freezing temperatures. All patches affected by cold temperatures were conditionally accepted. All patches exhibiting lack of strength or bond to the concrete base after a $350^{\circ} \mathrm{F}$ day ${ }^{5}$ curing period were removed and replaced. All patches were re-evaluated prior to placement of the secondary liner bottom.

\footnotetext{
5 “Degree-Days" (e.g. $350^{\circ} \mathrm{F}$ days) is a time-temperature factor used to estimate the in-place strength of concrete to allow the continuance of construction activities such as termination of cold weather protection (see ASTM C1074, Standard Practice for Estimating Concrete Strength by the Maturity Method, for details).
} 


\subsubsection{Tank Concrete Shell}

During placement of the concrete shells, low field-cured concrete cylinder breaks were a recurring issue. Concrete related issues were documented in the NCRs that are outline in Table 5-11.

Table 5-11. Concrete Shell Nonconformance Reports

\begin{tabular}{|c|c|c|c|}
\hline NCR \# \# $^{\mathrm{a}}$ & Tank & Description & Disposition \\
\hline B-340-101 & AP-108 & $\begin{array}{l}\text { Tank } 108 \text { - during placement of } \\
\text { concrete, forms gave way. Also, } \\
\text { vibration was not performed } \\
\text { adequately, causing some rock } \\
\text { pockets on the surface approximately } \\
4 \text { inches deep. }\end{array}$ & $\begin{array}{l}\text { Repair - remove concrete as } \\
\text { necessary to allow proper } \\
\text { installation of polysulfide sealant. } \\
\text { Provide improved formwork } \\
\text { support to prevent future formwork } \\
\text { displacement. Repair rock pockets } \\
\text { and verify vibration will be } \\
\text { improved on future pours. Excess } \\
\text { concrete will not affect the } \\
\text { structural integrity of the tank walls } \\
\text { and repair of rock pockets is } \\
\text { required per specification. (App. } \\
\text { Figure B-40) }\end{array}$ \\
\hline B-340-107 & AP-107 & $\begin{array}{l}\text { Tank } 107 \text { lower shell concrete breaks } \\
\text { at 28-days: field-cured cylinders } \\
\text { failed to make } 5000 \text { psi or } 85 \% \text { of } \\
\text { laboratory-cured cylinders. }\end{array}$ & $\begin{array}{l}\text { Accept as is - based on lab-cured } \\
\text { cylinders which meet specified } \\
\text { requirements. (App. Figure B-41) }\end{array}$ \\
\hline B-340-108 & AP-108 & $\begin{array}{l}\text { Tank } 108 \text { upper shell concrete breaks } \\
\text { at } 28 \text { days: field-cured cylinders } \\
\text { failed to make } 5000 \text { psi or } 85 \% \text { of } \\
\text { laboratory-cured cylinders. }\end{array}$ & $\begin{array}{l}\text { Accept as is: based on lab-cured } \\
\text { cylinders which meet specified } \\
\text { requirements. (App. Figure B-42) }\end{array}$ \\
\hline B-340-109 & AP-102 & $\begin{array}{l}\text { Tank } 102 \text { lower shell concrete breaks } \\
\text { at } 28 \text { days: field-cured cylinders } \\
\text { failed to make } 5000 \text { psi or } 85 \% \text { of } \\
\text { laboratory-cured cylinders. }\end{array}$ & $\begin{array}{l}\text { Accept as is - based on lab-cured } \\
\text { cylinders which meet specified } \\
\text { requirements. (App. Figure B-43) }\end{array}$ \\
\hline B-340-111 & AP-101 & $\begin{array}{l}\text { Tank } 101 \text { lower shell concrete breaks } \\
\text { at } 28 \text { days: field-cured cylinders } \\
\text { failed to make } 5000 \text { psi or } 85 \% \text { of } \\
\text { laboratory-cured cylinders. }\end{array}$ & $\begin{array}{l}\text { Accept as is - based on lab-cured } \\
\text { cylinders which meet specified } \\
\text { requirements. (App. Figure B-44) }\end{array}$ \\
\hline B-340-114 & AP-101 & $\begin{array}{l}\text { Tank } 101 \text { upper shell concrete breaks } \\
\text { at } 28 \text { days: field-cured cylinders } \\
\text { failed to make } 5000 \text { psi or } 85 \% \text { of } \\
\text { laboratory-cured cylinders. }\end{array}$ & $\begin{array}{l}\text { Accept as is - based on lab-cured } \\
\text { cylinders which meet specified } \\
\text { requirements. (App. Figure B-45) }\end{array}$ \\
\hline B-340-116 & AP-102 & $\begin{array}{l}\text { Tank } 102 \text { upper shell concrete breaks } \\
\text { at } 28 \text { days: field-cured cylinders } \\
\text { failed to make } 5000 \text { psi or } 85 \% \text { of } \\
\text { laboratory-cured cylinders. }\end{array}$ & $\begin{array}{l}\text { Accept as is - based on lab-cured } \\
\text { cylinders which meet specified } \\
\text { requirements. (App. Figure B-46) }\end{array}$ \\
\hline
\end{tabular}


Table 5-11. Concrete Shell Nonconformance Reports

\begin{tabular}{|c|c|c|c|}
\hline NCR $\#^{\mathbf{a}}$ & Tank & Description & Disposition \\
\hline B-340-117 & AP-106 & $\begin{array}{l}\text { Tank } 106 \text { lower shell concrete breaks } \\
\text { at } 28 \text { days: field-cured cylinders } \\
\text { failed to make } 5000 \text { psi or } 85 \% \text { of } \\
\text { laboratory-cured cylinders. }\end{array}$ & $\begin{array}{l}\text { Accept as is - based on lab-cured } \\
\text { cylinders which meet specified } \\
\text { requirements. (App. Figure B-47) }\end{array}$ \\
\hline B-340-118 & AP-102 & $\begin{array}{l}\text { During concrete placement on tank } \\
102 \text { dome, water inside the tank came } \\
\text { out of the filler holes [dome } \\
\text { penetrations] and entered the } \\
\text { concrete. The amount of water is not } \\
\text { known. The tank was full of water } \\
\text { treated with } 3500 \text { pounds of sodium } \\
\text { bicarbonate. }\end{array}$ & $\begin{array}{l}\text { Accept as is - the water washed } \\
\text { over the surface of a completed } \\
\text { area of the pour, washing away } \\
\text { sand and cement and exposing } \\
\text { aggregate. This damaged surface } \\
\text { area will be repaired. The } \\
\text { concentration of sodium } \\
\text { bicarbonate in the tank water is } \\
\text { significantly less than the } \\
\text { concentration which may cause } \\
\text { reduction in setting time and 28- } \\
\text { day concrete strength. The tank } \\
\text { water was not used for mixing and } \\
\text { was not allowed to mix with the } \\
\text { fresh concrete, causing no chemical } \\
\text { damage to the fresh concrete. (App. } \\
\text { Figure B-48) }\end{array}$ \\
\hline B-340-120 & AP-106 & $\begin{array}{l}\text { Tank } 106 \text { upper shell concrete break } \\
\text { at } 28 \text { days: field-cured cylinders } \\
\text { failed to make } 5000 \text { psi or } 85 \% \text { of } \\
\text { laboratory-cured cylinders. }\end{array}$ & $\begin{array}{l}\text { Accept as is - based on lab-cured } \\
\text { cylinders which meet specified } \\
\text { requirements. (App. Figure B-49) }\end{array}$ \\
\hline B-340-121 & AP-106 & $\begin{array}{l}\text { Temperature of concrete placed on } \\
\text { dome of tank } 106 \text { dropped below } \\
50^{\circ} \mathrm{F} \text { to a low of } 43^{\circ} \mathrm{F} \text { in one location. }\end{array}$ & $\begin{array}{l}\text { Conditional accept - provide } \\
\text { additional protection time to } \\
\text { develop compressive strength } \\
\text { comparable to those areas better } \\
\text { protected. Seven day field strength } \\
\text { tests indicated no damage to } \\
\text { concrete due to low initial curing } \\
\text { temperature. (App. Figure B-50) }\end{array}$ \\
\hline B-340-124 & AP-107 & $\begin{array}{l}\text { Concrete cylinder breaks for tank } 107 \\
\text { dome area: field-cured cylinders } \\
\text { failed to make } 5000 \text { psi or } 85 \% \text { of } \\
\text { laboratory-cured cylinders. }\end{array}$ & $\begin{array}{l}\text { Accept as is - lab results show that } \\
\text { concrete will develop the required } \\
\text { strength to perform properly. (App. } \\
\text { Figure B-51) }\end{array}$ \\
\hline B-340-125 & AP-105 & $\begin{array}{l}\text { Tank } 105 \text { lower shell concrete breaks } \\
\text { at } 28 \text { days: field cured cylinders } \\
\text { failed to make } 5000 \text { psi or } 85 \% \text { of } \\
\text { laboratory-cured cylinders. }\end{array}$ & $\begin{array}{l}\text { Accept as is - based on engineering } \\
\text { judgment, ignore the results of tests } \\
\text { on one of three field-cured } \\
\text { cylinders. It must not have received } \\
\text { the same curing and protection as } \\
\text { the others, since all three lab-cured } \\
\text { cylinders show consistency in } \\
\text { strength. (App. Figure B-52) }\end{array}$ \\
\hline
\end{tabular}


Table 5-11. Concrete Shell Nonconformance Reports

\begin{tabular}{|c|c|c|c|}
\hline NCR $\#^{\mathrm{a}}$ & Tank & Description & Disposition \\
\hline B-340-126 & $\begin{array}{l}\text { AP-103, } \\
\text { AP-104, } \\
\text { AP-105, } \\
\text { AP-106 }\end{array}$ & $\begin{array}{l}\text { Form ties were not removed } \\
\text { immediately after removal of } \\
\text { concrete forms on tanks } 103,104 \text {, } \\
105 \text {, and } 106 . \text { Form ties on tank } 106 \\
\text { (haunch pour area) were removed } \\
12 / 18 / 84 \text {. Concrete was heated up } \\
\text { prior to patching with grout mix. } \\
\text { After patch was placed, no curing was } \\
\text { performed. (overnight temperatures } \\
\text { was } 0^{\circ} \mathrm{F} \text { ). }\end{array}$ & $\begin{array}{l}\text { Repair - remove and replace all } \\
\text { patched areas exhibiting lack of } \\
\text { strength or bond to the original } \\
\text { concrete. The repair must develop } \\
\text { adequate strength and bond to } \\
\text { provide a watertight joint to protect } \\
\text { reinforcing steel. (App. Figure } \\
\text { B-53) }\end{array}$ \\
\hline B-340-127 & AP-102 & $\begin{array}{l}\text { Concrete cylinder breaks for tank } 102 \\
\text { dome area: field curing cylinders } \\
\text { failed to make } 5000 \text { psi of laboratory- } \\
\text { cured cylinders. }\end{array}$ & $\begin{array}{l}\text { Accept as is - lab results show that } \\
\text { concrete will develop the required } \\
\text { strength to perform properly. (App. } \\
\text { Figure B-54) }\end{array}$ \\
\hline B-340-129 & AP-101 & $\begin{array}{l}\text { Concrete cylinder breaks for tank } 101 \\
\text { dome area: field-cured cylinders to } \\
\text { make } 5000 \text { psi or } 85 \% \text { of laboratory- } \\
\text { cured cylinders. }\end{array}$ & $\begin{array}{l}\text { Accept as is: lab results show that } \\
\text { concrete will develop the required } \\
\text { strength to perform properly. (App. } \\
\text { Figure B-55) }\end{array}$ \\
\hline B-340-130 & AP-104 & $\begin{array}{l}\text { Concrete cylinder breaks for tank } 104 \\
\text { haunch area: field cured cylinders } \\
\text { failed to make } 5000 \text { psi or } 85 \% \text { of } \\
\text { laboratory-cured cylinders. }\end{array}$ & $\begin{array}{l}\text { Conditional accept - acceptance of } \\
\text { curing and protection of the } \\
\text { concrete shall be based on the } \\
\text { additional field cured cylinders held } \\
\text { for a } 45 \text { day break. (App. Figure } \\
\text { B-56) }\end{array}$ \\
\hline B-340-132 & AP-103 & $\begin{array}{l}\text { Field cured cylinders for the tank } 103 \\
\text { haunch area failed to make } 5000 \text { psi } \\
\text { or } 85 \% \text { of the laboratory-cured } \\
\text { cylinders. }\end{array}$ & $\begin{array}{l}\text { Conditional accept - acceptance of } \\
\text { curing and protection of the } \\
\text { concrete pour shall be based on the } \\
\text { additional field cured cylinders held } \\
\text { for a } 45 \text { day break. (App. Figure } \\
\text { B-57) }\end{array}$ \\
\hline B-340-134 & AP-103 & $\begin{array}{l}\text { Tank } 103 \text { dome concrete cylinder } \\
\text { breaks at } 28 \text { days: field cured } \\
\text { cylinders failed to make } 500 \text { psi or } \\
85 \% \text { of laboratory-cured cylinders. }\end{array}$ & $\begin{array}{l}\text { Accept as is - lab results show that } \\
\text { concrete will develop the required } \\
\text { strength to perform properly. (App. } \\
\text { Figure B-58) }\end{array}$ \\
\hline
\end{tabular}

a. NCRs included as App. Figure B-40 through .

Several NCRs listed in the above table were generated because of a lack of compressive strength in the field-cured concrete cylinders. In each case, the issue was "accepted as is" because the lab-cured cylinders met the compressive strength specifications provided in Specification B-340-C4.

NCR B-340-118 (see App. Figure B-48) was written when an unknown amount of water inside the tank spilled out of the filler holes (filler holes are assumed to be dome penetrations known as risers) and entered the concrete during tank 102 dome concrete placement. The tank was full of 
water treated with 3500 pounds of sodium bicarbonate. Sand and cement were washed away as a result of the spill, exposing some aggregate. The disposition of the NCR states that "This damaged surface area will be repaired.” The justification of the NCR says that the concentration of sodium bicarbonate was significantly less than the concentration which could have caused a reduction in settling time and 28-day concrete strength. It is also noted that the water was not used for mixing and was not allowed to mix with concrete, causing no chemical damage to the fresh concrete.

On 12/6/1984, NCR B-340-121 (see App. Figure B-50) was generated when temperature of the concrete placed on tank dome 106 dropped below the specified $50^{\circ} \mathrm{F}$ (B-340-C4) to a low of $43^{\circ} \mathrm{F}$ in one location. The disposition of this issue was to provide additional protection time to develop compressive strength comparable to areas better protected. 


\subsection{CONCLUSION}

The leak assessment report for tank AY-102, RPP-ASMT-53793, identified first-of-a-kind construction difficulties and trial-and-error repairs that compromised the intended robustness of the tank. To determine whether improvements in DST construction continued and whether similar or other difficulties were present, a review and evaluation of the construction records for the 241-AP tank farm were completed.

After a review of the construction history of the 241-AP tank farm, it is concluded that, during construction of the 241-AP tank farm, there were fewer construction difficulties. Table 6-1 includes a summary comparison of the issues seen in tank AY-102 and the 241-AP tank farm, focusing on the critical difficulties that were identified in RPP-ASMT-53793.

The secondary liner bottom thickness was increased from 1/4-in. in the 241-AY tank farm to 3/8-in. in the 241-AP tank farm and the primary tank bottom thickness was increased from 3/8-in. to 1/2-in. The American Society for Testing and Materials (ASTM) A537-79 carbon steel plate material utilized in the 241-AP tank farm also varied from the ASTM A515-65 carbon steel plate used in the 241-AY tank farm. ASTM A537 provides higher yield strength.

The 241-AP tank farm experienced primary tank bottom weld rejection rates ranging between $5 \%$ and $12 \%$. High weld rejection rates and subsequent repairs are thought to be a contributor to out-of-tolerance distortions, or bulges, found during previous tank farm tank construction, such as in the 241-AY and 241-SY tank farms. In the 241-AP tank farm, this does not appear to be a significant issue with some of the lowest weld rejection rates seen throughout all of Hanford's double-shell tanks. All initially rejected welds were eventually approved, following acceptable repair, and post-weld stress relief of the primary tank was accepted as successfully completed. There were two out-of-specification bulges in primary tank AP-104. Dead weight was placed on the bulges, which brought the primary bottom into specification. No bulges were found in any of the secondary liner bottoms.

The construction specification of $1100^{\circ} \mathrm{F}$ for one hour per one inch thickness was not met, but the alternate code requirement of $1000^{\circ} \mathrm{F}$ for three hours per one inch thickness was adopted as standard practice after problems with dome deformation were seen in previous tank farms (241AW and 241-AN). There is a higher certainty of proper stress relief in the 241-AP tank farm than was noted for tank 241-AY-102. However, tank AP-108 post-weld stress relief was accepted based on a holding temperature of $950^{\circ} \mathrm{F}$ for a period of 5 hours, because the permanent thermocouples installed in the refractory below the primary tank bottom did not reach $1000^{\circ} \mathrm{F}$.

Litecrete 60M was the castable refractory material utilized in the 241-AP tank farm tanks. For tanks AP-101 through AP-107, no indication of out-of-specification refractory was found. In tank AP-108, plastic shrinkage cracks were found in the refractory, caused by rapid curing. The minor cracks were filled with refractory material and the refractory was accepted.

Other issues, unique to the 241-AP tank farm, were noted. Surface defects and plate damage was discovered during inspection of the material. This damage was directed to be repaired per approved procedures. These defects included laminations, scabbing, and pitting. Tank dome distortions were observed and noted on the domes of tanks AP-103, AP-104, AP-105, and 
AN-107 following stress relief. Additional anchor studs were added to adequately support the dome and the conditions were accepted as is.

The 241-AP tank farm was the sixth DST farm constructed; American Bridge was chosen to construct the tank farm. American Bridge also constructed the 241-AW and 241-AN tank farms. Tank bottom bulging, out-of-tolerance conditions were non-existent, and refractory material quality and post-weld stress relief were much improved over that seen in tank AY-102. Lower weld rejection rates occurred in the 241-AP tank farm compared to tank AY-102. These issues, along with others that were judged to be minor (e.g. concrete foundation and encasement repairs and weld joint preparation). Overall condition of the 241-AP tank farm following construction is judged to be better than that of tank AY-102. 
RPP-RPT-55983, Rev. 0

Table 6-1. Summary Comparison 241-AP Tank Farm Construction to Tank AY-102

\begin{tabular}{|c|c|c|c|c|c|c|c|c|c|}
\hline Tank & AY-102 & AP-101 & AP-102 & AP-103 & AP-104 & AP-105 & AP-106 & AP-107 & AP-108 \\
\hline $\begin{array}{l}\text { Evaluation } \\
\text { Document }\end{array}$ & $\begin{array}{l}\text { RPP-ASMT-53793, } \\
\text { Tank 241-AY-102 Leak } \\
\text { Assessment Report }\end{array}$ & \multicolumn{8}{|c|}{ RPP-RPT-55983, 241-AP Tank Farm Construction Extent of Condition Review for Tank Integrity } \\
\hline Construction Order & $1^{\text {st }}$ DST constructed & $4^{\text {th }}$ DST in $6^{\text {th }}$ Farm & $3^{\text {rd }}$ DST in $6^{\text {th }}$ Farm & $7^{\text {th }}$ DST in $6^{\text {th }}$ Farm & $6^{\text {th }} \mathrm{DST}$ in $6^{\text {th }}$ Farm & $8^{\text {th }}$ DST in $6^{\text {th }}$ Farm & $5^{\text {th }}$ DST in $6^{\text {th }}$ Farm & $2^{\text {nd }}$ DST in $6^{\text {th }}$ Farm & $1^{\text {st }}$ DST in $6^{\text {th }}$ Farm \\
\hline $\begin{array}{l}\text { Construction } \\
\text { Contractor }\end{array}$ & $\begin{array}{l}\text { Pittsburgh-Des Moines } \\
\text { (PDM)Steel Company }\end{array}$ & \multicolumn{8}{|c|}{ American Bridge Division of US Steel Corporation } \\
\hline $\begin{array}{l}\text { Secondary Bottom } \\
\text { Material }\end{array}$ & $\begin{array}{l}\text { 0.25-in. plate, ASTM } \\
\text { A515, Gr } 60\end{array}$ & \multicolumn{8}{|c|}{ 0.375-in. plate, ASTM A537, Class 1} \\
\hline $\begin{array}{l}\text { Secondary Liner } \\
\text { Bottom Bulges }\end{array}$ & $\begin{array}{l}\text { Excessive distortion } \\
\text { and bulges noted } \\
\text { throughout. Maximum } \\
\text { slope noted as much as } \\
\text { 1-in./ft. } 22 \text { places } \\
\text { exceed 2-in. peak-to- } \\
\text { valley tolerance. }\end{array}$ & \multicolumn{8}{|c|}{ No out-of-tolerance bulges identified. } \\
\hline $\begin{array}{l}\text { Primary Bottom } \\
\text { Material }\end{array}$ & $\begin{array}{l}\text { 0.375-in. plate, ASTM } \\
515, \text { Gr } 60\end{array}$ & \multicolumn{8}{|c|}{ 0.5-in. plate, ASTM A537, Class 1} \\
\hline & $33.8 \%$ & $6 \%$ & $9 \%$ & $10 \%$ & $9 \%$ & $12 \%$ & $6 \%$ & $7 \%$ & $5 \%$ \\
\hline $\begin{array}{l}\text { Primary Bottom } \\
\text { Weld Rework }\end{array}$ & $\begin{array}{l}\text { Ultimately all welds } \\
\text { were accepted and } \\
\text { stress relieved, } \\
\text { although problems with } \\
\text { that process were } \\
\text { noted. }\end{array}$ & \multicolumn{8}{|c|}{ Ultimately all welds were accepted and stress relieved. } \\
\hline $\begin{array}{l}\text { Primary Liner } \\
\text { Bottom Bulges }\end{array}$ & $\begin{array}{l}\text { Primary bottom } \\
\text { flatness described as } \\
\text { "generally good." }\end{array}$ & \multicolumn{3}{|c|}{ No out-of-tolerance bulges identified } & $\begin{array}{l}\text { Two out of tolerance } \\
\text { areas noted until dead } \\
\text { weight was placed on } \\
\text { them. Re-survey } \\
\text { showed the tank bottom } \\
\text { to be within specified } \\
\text { tolerances. }\end{array}$ & \multicolumn{4}{|c|}{ No out-of-tolerance bulges identified } \\
\hline $\begin{array}{l}\text { Stress Relieving } \\
\text { Process }\end{array}$ & $\begin{array}{l}\text { Required } 2 \text { days to } \\
\text { remove all the water in } \\
\text { the refractory and } \\
\text { temperature recorder } \\
\text { just prior to initiating } 3 \\
\text { hour hold time was } \\
915^{\circ} \mathrm{F} \text { (accepted as } \\
\left.\text { being } 1000^{\circ} \mathrm{F}\right) \text {. }\end{array}$ & $\begin{array}{l}\text { Three hour hold at } \\
1000^{\circ} \mathrm{F} \text {. }\end{array}$ & $\begin{array}{l}\text { Three hour hold at } \\
\qquad 1000^{\circ} \mathrm{F} \text {. } \\
\text { Four thermocouples, } \\
\text { representing a large } \\
\text { portion of the primary } \\
\text { bottom, failed prior to } \\
\text { final soak. }\end{array}$ & $\begin{array}{l}\text { Three hour hold at } \\
1000^{\circ} \mathrm{F} \text {. }\end{array}$ & $\begin{array}{l}\text { Three hour hold at } \\
1000^{\circ} \mathrm{F} \text {. } \\
\text { Specified heat-up time } \\
\text { was exceeded by } 2 \\
\text { hours. }\end{array}$ & $\begin{array}{l}\text { Three hour hold at } \\
\qquad 1000^{\circ} \mathrm{F} \text {. }\end{array}$ & $\begin{array}{l}\text { Three hour hold at } \\
\quad 1000^{\circ} \mathrm{F} \text {. } \\
\text { Two thermocouples in } \\
\text { measure tank bottom } \\
\text { temperature failed to } \\
\text { reach the } 1000^{\circ} \mathrm{F} \text { hold } \\
\text { temperature. }\end{array}$ & $\begin{array}{l}\text { Three hour hold at } \\
\qquad 1000^{\circ} \mathrm{F} \text {. } \\
\text { Permanent bottom } \\
\text { thermocouples never } \\
\text { reached the } 1000^{\circ} \mathrm{F} \text { hold } \\
\text { temperature. Temporary } \\
\text { thermocouples did } \\
\text { reach the required } \\
\text { temperature. }\end{array}$ & $\begin{array}{l}\text { Five hour hold at } \\
\quad 950^{\circ} \mathrm{F} \text {. } \\
\text { Permanent bottom } \\
\text { thermocouples never } \\
\text { reached the } 1000^{\circ} \mathrm{F} \text { hold } \\
\text { temperature. Temporary } \\
\text { thermocouples did } \\
\text { reach the required } \\
\text { temperature. An } \\
\text { alternate code } \\
\text { requirement of } 950^{\circ} \mathrm{F} \\
\text { for } 5 \text { hours was } \\
\text { satisfied. }\end{array}$ \\
\hline Refractory & Kaolite 2200-LI & \\
\hline
\end{tabular}


RPP-RPT-55983, Rev. 0

\begin{tabular}{|c|c|c|c|c|c|c|c|c|c|}
\hline Tank & AY-102 & AP-101 & AP-102 & AP-103 & AP-104 & AP-105 & AP-106 & AP-107 & AP-108 \\
\hline $\begin{array}{l}\text { Refractory } \\
\text { Protection }\end{array}$ & $\begin{array}{l}\text { Allowed to saturate } \\
\text { with rain water, not } \\
\text { protected from } \\
\text { freezing. }\end{array}$ & \multicolumn{8}{|c|}{ Heaters were used to keep the cast refractory from freezing. Plastic sheeting was used to protect the refractory from rain, and wind that might cause plastic shrinkage of the refractory from curing to fast. } \\
\hline $\begin{array}{l}\text { Refractory } \\
\text { Condition }\end{array}$ & $\begin{array}{l}\text { After hydro test } \\
\text { refractory found to be } \\
\text { degraded, extensively } \\
\text { cracked and spalled. } \\
\text { Samples showed } \\
\text { excessive carbonation. }\end{array}$ & \multicolumn{7}{|c|}{ No reports on post cured refractory inspection were found } & $\begin{array}{l}\text { Plastic shrinkage cracks } \\
\text { were found in the } \\
\text { refractory caused by } \\
\text { poor weather protection. } \\
\text { The refractory was } \\
\text { covered with plastic, } \\
\text { however, the ends were } \\
\text { left open and wind was } \\
\text { allowed to blow across } \\
\text { the refractory, causing } \\
\text { the refractory to cure } \\
\text { too quickly and develop } \\
\text { plastic shrinkage cracks. }\end{array}$ \\
\hline Refractory Repair & $\begin{array}{l}21 \text { inches of perimeter } \\
\text { removed and replaced } \\
\text { with concrete and rebar }\end{array}$ & \multicolumn{7}{|c|}{ None reported } & $\begin{array}{l}\text { Minor repairs were } \\
\text { made to fill the cracks } \\
\text { found in the refractory } \\
\text { during initial pour. }\end{array}$ \\
\hline Other Issues & $\begin{array}{l}\text { Unsupported areas of } \\
\text { primary bottom filled } \\
\text { with foam. }\end{array}$ & $\begin{array}{l}\text { Excessive foundation } \\
\text { concrete vibration } \\
\text { resulted in segregation. } \\
\text { Out-of-tolerance } \\
\text { concrete foundation. } \\
\text { Low compressive } \\
\text { strength in field-cured } \\
\text { concrete shell testing. }\end{array}$ & $\begin{array}{l}\text { Slow rate of foundation } \\
\text { concrete placement } \\
\text { resulted in cold joint. } \\
\text { Inadequate foundation } \\
\text { concrete vibration } \\
\text { resulted in air voids and } \\
\text { stone pockets. Concrete } \\
\text { foundation repair } \\
\text { patches were not } \\
\text { adequately protected } \\
\text { from cold temperatures } \\
\text { and repairs were made. } \\
\text { Foundation drain slots } \\
\text { varied from elevation } \\
\text { tolerances. Low } \\
\text { compressive strength in } \\
\text { field-cured concrete } \\
\text { shell testing. Dome } \\
\text { deformations occurred } \\
\text { near riser \#5 and } \\
\text { additional anchor studs } \\
\text { were added. }\end{array}$ & $\begin{array}{l}\text { Low compressive } \\
\text { strength in field-cured } \\
\text { concrete shell testing. } \\
\text { Dome deformations } \\
\text { occurred near riser \#5 } \\
\text { and additional anchor } \\
\text { studs were added. } \\
\text { Inadequate preparation } \\
\text { of surface prior to weld } \\
\text { operations. }\end{array}$ & $\begin{array}{l}\text { Low compressive } \\
\text { strength in field-cured } \\
\text { concrete shell testing. } \\
\text { Dome deformations } \\
\text { occurred near riser \#5 } \\
\text { and additional anchor } \\
\text { studs were added. }\end{array}$ & $\begin{array}{l}\text { Concrete foundation } \\
\text { repair patches were not } \\
\text { adequately protected } \\
\text { from cold temperatures } \\
\text { and repairs were made. } \\
\text { Low compressive } \\
\text { strength in field-cured } \\
\text { concrete shell testing. } \\
\text { Dome deformations } \\
\text { occurred near riser \#5 } \\
\text { and additional anchor } \\
\text { studs were added. }\end{array}$ & $\begin{array}{l}\text { Low compressive } \\
\text { strength in field-cured } \\
\text { concrete shell testing. } \\
\text { Tank dome concrete } \\
\text { dropped below } 50^{\circ} \mathrm{F} \\
\text { prior to cure. Dome } \\
\text { concrete was accepted } \\
\text { based on seven day } \\
\text { field-cure strength tests. }\end{array}$ & $\begin{array}{l}\text { Visual inspection did } \\
\text { not occur between weld } \\
\text { passes on several } \\
\text { occasions. Dome } \\
\text { deformations occurred } \\
\text { near riser \#5 and } \\
\text { additional anchor studs } \\
\text { were added. Inadequate } \\
\text { preparation of surface } \\
\text { prior to weld } \\
\text { operations. }\end{array}$ & $\begin{array}{l}\text { Inadequate use of } \\
\text { moisture-retaining } \\
\text { membrane. Excessive } \\
\text { foundation concrete } \\
\text { vibration resulted in } \\
\text { segregation. Low } \\
\text { compressive strength in } \\
\text { field-cured concrete } \\
\text { shell testing. Visual } \\
\text { inspection did not occur } \\
\text { between weld passes on } \\
\text { several occasions. } \\
\text { Inadequate preparation } \\
\text { of surface prior to weld } \\
\text { operations. }\end{array}$ \\
\hline
\end{tabular}


RPP-RPT-55983, Rev. 0

In the 241-AP tank farm, weld rejection rates do not appear to be a significant issue, with some of the lowest seen throughout all of Hanford's double-shell tanks. There were two out-of-specification bulges in primary tank AP-104. Dead weight was placed on the bulges, which brought the primary bottom into specification. No bulges were found in any of the secondary liner bottoms. There is a higher certainty of proper stress relief in the 241-AP tank farm than was noted for tank 241-AY-102 and fewer overall stress relief difficulties were noted. No indication of out-of-specification refractory was found. No information on post-weld hea

unsupported areas in

unexpected residual

stresses in the tank

treatment condition of refractory was recovered from the records archives. In tank AP-108, plastic shrinkage cracks were found in the refractory, caused by rapid curing. The minor cracks were filled with refractory

bottom that probably

contributed to failure. 
RPP-RPT-55983, Rev. 0

\subsection{REFERENCES}

B-340-C1, 1982, Construction Specification for the 241-AP Tank Farm Site Preparation, Kaiser Engineers Hanford Company, Richland, Washington.

B-340-C2, 1982, Construction Specification for the 241-AP Tank Farm Site Excavation, Kaiser Engineers Hanford Company, Richland, Washington.

B-340-C3, 1982, Construction Specification for the 241-AP Tank Farm Tank Foundations, Kaiser Engineers Hanford Company, Richland, Washington.

B-340-C4, 1982, Construction Specification for Primary and Secondary Steel Tanks 241-AP Tank Farm, Kaiser Engineers Hanford Company, Richland, Washington.

B-340-C5, 1982, Construction Specification for the 241-AP Tank Farm Tank Encasement, Kaiser Engineers Hanford Company, Richland, Washington.

B-340-C6, 1982, Construction Specification for the 241-AP Tank Farm Backfill, Kaiser Engineers Hanford Company, Richland, Washington.

B-340-C7, 1982, Construciton Specification for the 241-AP Tank Farm Completion, Kaiser Engineers Hanford Company, Richland, Washington.

B-340-C8, 1982, Construction Specification for the 241-AP Tank Farm - 242A Evaporator Modifications, Kaiser Engineers Hanford Company, Richland, Washington.

B-340-C9, 1984, Construction Specification for 241-AP Tank Farm Cathodic Protection Systems, Kaiser Engineers Hanford Company, Richland, Washington.

B-340-C10, 1986, Construction Specification for 241-AP Tank Farm Additional Pipe Line, Kaiser Engineers Hanford Company, Richland, Washington.

B-340-D1, 1981, Design Specification for Primary and Secondary Steel Tanks 241-AP Tank Farm, Kaiser Engineers Hanford Company, Richland, Washington.

H-2-77447, 1988, STRL Tank Dome Penetration Plan and Details, Kaiser Engineers Hanford Company, Richland, Washington.

H-2-90439, 1982, Structural Concrete Tank Foundation Plan and Details, Kaiser Engineers Hanford Company, Richland, Washington.

H-2-90441, 1982, Structural Dome Reinforcement Plan and Details, Kaiser Engineers Hanford Company, Richland, Washington.

H-2-90442, 1982, Structural Tank Section and Haunch Reinforcement, Kaiser Engineers Hanford Company, Richland, Washington. 
H-2-90534, 1981, Tank Cross Section 241-AP Tanks, Kaiser Engineers Hanford Company, Richland, Washington.

H-14-010503, 2010, Dome Penetration Schedules (WST/WSTA) Tank 241-AP-107, U.S. Department of Energy Office of River Protection, Richland, Washington.

RPP-RPT-55981, 2013, 241-AW Tank Farm Construction Extent of Condition Review for Tank Integrity, Washington River Protection Solutions, Richland, Washington.

Integrated Data Management System (IDMS), Queried 2/5/2014, [241-AP-107 Riser Installation Structural Analysis Project W-E01], http://idmsweb.rl.gov/idms/livelink.exe.

Integrated Data Management System (IDMS), Queried 2/5/2014, [241-AP Tank Farm Steel Plate Damage NCRs], http://idmsweb.rl.gov/idms/livelink.exe.

SD-340-FDC-001, Rev. 2, 1986, Functional Design Criteria, Rockwell Hanford Operations, Richland, Washington. 
RPP-RPT-55983, Rev. 0

APPENDIX A SUPPORTING DOCUMENTATION 


\section{App. Figure A-1. Refractory Certificate of Compliance}

\section{VERTECSS}

P.O. BOX 675

(206) $823 \cdot 2505$

12601 - 132ND AVE. N.E. - KIRKLAND. WASHINGTON 98033

July 18,1983

American Bridge
P O Box 1407
Richland WA 99352
Re: T-3036 Eight Waste Storage Tanks
Tank Farm 241-AP
Richland Washington

Gentlemen:

Submittals for Section 3341 - Castable Refractory

1.2.1 Certificate of Compliance

Enclosure A - North American Refractories

1.2.2 Refractory Proportioning and Mixing Data:

Enclosure A - North American Refractories

1.2.3 Depositing Procedures

a. General - Dry refractory will be mixed with water (see paragraph 1.2.2. above) in a dual drum rotating paddle mixer, dumped into a hopper feeding a progressing cavity (Moyno type) pump discharging through a three inch hose, approximately $100 \mathrm{ft}$ long, ending with a flexible whip.

It is planned to use a pre-set fabricated steel tubing block-out assembly to produce the air slots.

b. Cold weather - Castable Refractory generates substantial heat during the setting reaction. Heating the mixing water will increase the reaction rate and temperature rise. (see paragraph 1.2.5.2 below) otherwise no change in procedure.

c. Hot weather - no change in procedure (see paragraph 1.2.5.3 below)

1.2.4 Block diagram - Drawing 4520 represents $\frac{1}{4}$ of a tank base, Enclosure B. One quadrant should be poured in one day.

1.2.5 Protection Procedures -

1.2.5.1 Mechanical injury - Barracades and a watchman if needed will prevent mechanical injury during the setting period.

1.2.5.2 Atmospheric temperature below $40^{\circ}$ -

a. Temperature during pour expected to remain between $32^{\circ}$ and $40^{\circ}$. Heat mixing water so that temperature of mix is between $50^{\circ}$ and $70^{\circ} \mathrm{F}$. When set, cover with sheet plastic or plywood.

$$
\begin{gathered}
\text { SPECIALTY INSULATION CONTRACTORS } \\
\text { POLYURETHANE FOAM AND COATINGS } \\
\text { LIGHTWEIGHT CONCRETE ROOFDECK SYSTEMS } \\
\text { SPRAYON ACOUSTICAL AND FIREPROOFING TREATMENT } \\
\text { PREINSULATED OR FIELD INSTALLED UNDERGROUND PIPE CONDUITS } \\
\text { WASHINGTON STATE CONTRACTORS REG. NO. } 223.02-V E \text {-RT-E..37ONO }
\end{gathered}
$$


RPP-RPT-55983, Rev. 0

\section{VERTECS}

American Bridge page $2 \quad$ Ju1y 18,1983

T-3036 Eight Waste Storage Tanks

1.2.5.2 b. Temperature during pour expected to rise above $40^{\circ}$ within three hours. No special protection required.

c. Temperature during pour below $40^{\circ} \mathrm{F}$ and expected to drop below $32^{\circ} \mathrm{F}$, overnight. Heat mixing water as in a. above, place 2 in, thick expanded polystyrene board over surface, and cover with tarpaulin or plywood sheets.

1.2.5.3 Protection when atmospheric temperature is above $90^{\circ}$.

a. After set, place burlap over surface and keep wet with water until surface temperature drops below $90 \mathrm{~F}$.

1.2.5.4" Method of heating protective enclosure.

a. Electric resistance strip heaters $110 / 220 \mathrm{~V} \mathrm{AC}, 5$ to 10 watts per L.F. will be placed under insulation board in direct contact with refractory surface to maintain $40^{\circ} \mathrm{F}$ minimum temperature.

1.2.6 Curing Procedure

Surface protection after set shall be provided as recommended by North American Refractories Company and as suggested in paragraph 3.3 curing.

1.2.6.1 For normal atmospheric temperatures, $40-90^{\circ} \mathrm{F}$, moisture retention to prevent surface dryir.g will be provided by water spray after set, 24 hours to full cure.

1.2.6.2 For abnormal air temperatures, below $40^{\circ} \mathrm{F}$ and above $90^{\circ} \mathrm{F}$, curing procedures follow the submittals, paragraph 1.2.5 Protection Procedures. 48 hours is the time for full cure at low temperatures below $40^{\circ} \mathrm{F}$.

Sincerely,
VERTECS CORPORATION

Enclosures

L. L. Loper

LLL: go 
North American Refractories Co. An ALEed Company

WESTERN DIVISION
$1555 \mathrm{~N}$. Porkside Drive

Pittsburg, CA. 94565

(415) $432-4741$

July 15,1983

Vertecs Corp.

P.O. Box 675

12601 132nd N.E.

Kirkland, Wa. 98033

ATTN: Mr. Les Loper, President

RE: U.S. Department of Energy Contract 非E-AC06-82RL10367 KEH Jon R295A2, B-340-C4, Section 03341. (Construction Specifications for the 241-AP

Tank Farm Tank Foundations. Work Order X34002, prepared by Kaiser Engineers Hanford Company, Richland, Washington.)

This is to certify that Litecrete $60 \mathrm{M}$ produced by North American Refractories Co. in Renton, Washington complies with physical and insulating properties as specified by B-340-C3. Section 03341 . C4

Test data developed by the Pittsburg Laboratory of North American Refractories Co. and from Northwest Laboratories, an independent testing laboratory in Seattle, Washington are submitted as evidence of compliance with this specification. Test samples were obtained from samples pump placed by Vertecs Corporation on 4/15/83.

All material to be supplied for this project will be manufactured at Renton, Washington of the same type and quality as samples submitted for certification qualification. The product is designated Litecrete 60M.

Recommendations for mixing and curing Litecrete $60 \mathrm{M}$ are attached.

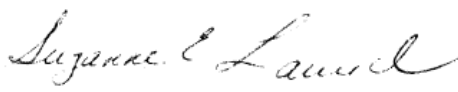

Suzanne E. Laurich

Senior Project Engineer

Pittsburg Laboratory

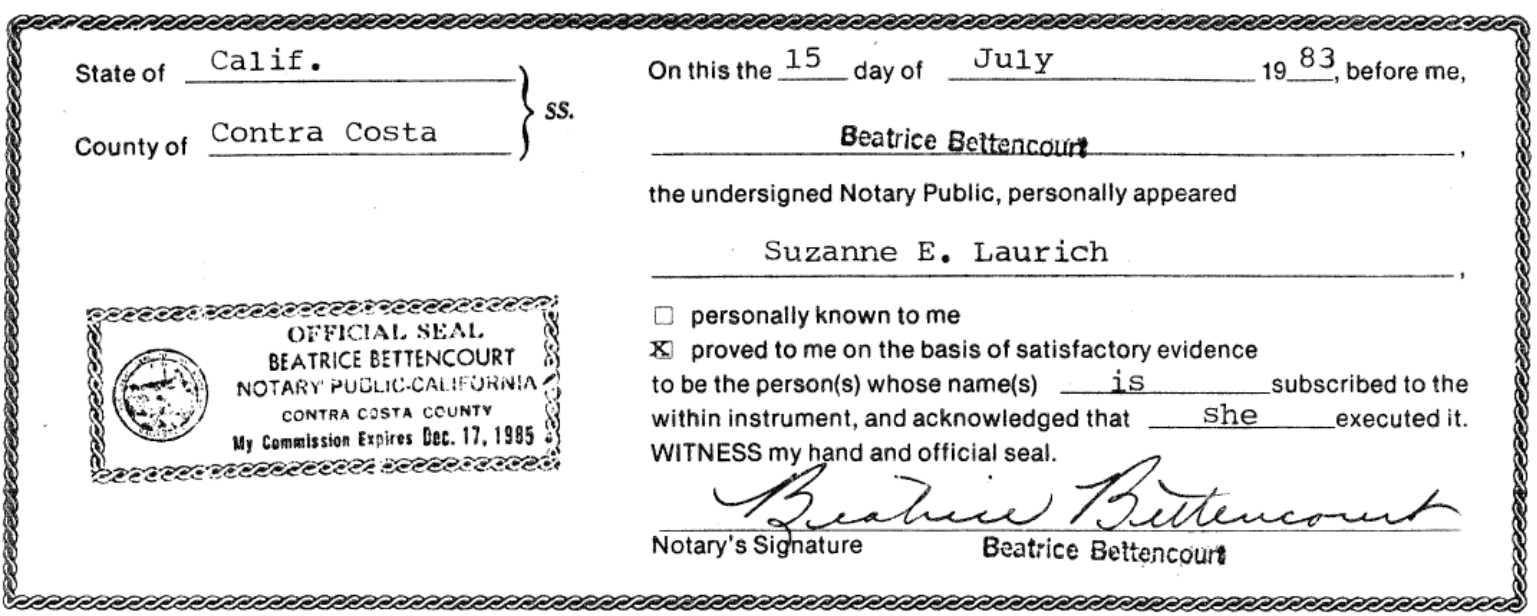


RPP-RPT-55983, Rev. 0

App. Figure A-2. 107-AP Riser/Pit Installation Scope and Status Update

107297

V. Westinghouse

Hanford Company

P.O. Box 1970 Richland, WA 99352

8755402

Mr. J. R. Mills, Project Engineer

Kaiser Engineers Hanford Company

Post Office Box 888

Richland, Washington 99352

Dear Mr. Mills:

ER-4350, 107-AP AND 108-AP RISER/PIT INSTALLATION, SCOPE AND STATUS UPDATE

The purpose of this letter is to modify the scope of the upcoming construction, clarify the issues discussed in recent status meetings, and to approve the transition of the structural analysis from phase I to phase II.

Due to funding limitations construction will be performed on only the 107-AP tank in fiscal year 1988. However, the design media should show both 107-AP and 108-AP modifications. The project cost estimate and schedule should only reflect the modifications to 107-AP.

Several issues have arisen in recent status meetings concerning the pump lowering mechanism and its interface with the new risers and pits. Based on the current conceptual design media generated by Westinghouse Hanford Company (WHC) the following items should be considered in the design media for this project:

0 The lowering mechanism will weigh 27,500 pounds and will be supported by an overhead structure.

- The project design media should show only a standard pit cover. A revised pit coverblock will be designed at a later date incorporating a
penetration.

As more information becomes avallable on the lowering mechanism you will be updated on any pertinent modifications required for the design.

The WHC review of phase I of the structural analysis has begun and, based on the method of analysis, WHC concurs with the approach taken and approves the continuance of the analysis into phase II. Formal approval or a request to modify assumptions, of the phase I analysis will be made after further review. Please forward any information on phase II to me as soon as possible. 
RPP-RPT-55983, Rev. 0

Mr. J. R. Mills

Page 2 Please call me at 373-1802 if you have any questions pertaining to this
project.

Very truly yours,

Luenory 2 Atonder

G. E. Hansen

Waste Management Project

Definition Section

ran 


\section{App. Figure A-3. 107-AP Post-Construction Riser Installation Stress Relief Discussion}

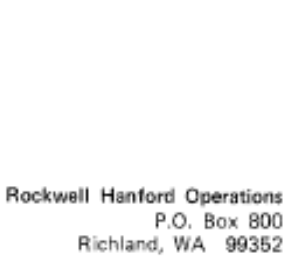

JUN 081987
Redistribution/JRM/6-11-87

M. D. Chang

C. J. Denson

E. A. Goakey

Y. Ingram/Central Files

R. M. Iten (for info. only)

J. R. Nicholson

international JRM File

In reply, refer to letter $\mathrm{R} 87-2493$

J. R. M1115, Project Engineer

Kaiser Engineers Hanford Company

Post Office Box 888

Richland, Washington 99352

Dear Mr. Mills:

107-AP AND 108-AP RISER/PIT INSTALLATION, ADDITIONAL DESIGN INFORMATION

Attached is the information your organization requested for the subject design effort. This information pertains to operating specifications for the mixer pump and the Quality Assurance recommendations for stress relief.

Attachment (1) provides the specifications for the normal operating torque, the starting torque, and the worst case bending moment and rotor torque. These values are based on the 102-AP mixer pump and may change dependent on the final design of the agitator pumps.

Attachment (2) is one opinion on the requirement for stress relief. This attachment is provided for your information only and is currentiy not Rockwell's formal posftion. Other Rockwell organizations must review the need to stress relieve both on the basis of the ASME codes and using a risk analysis type evaluation. If a satisfactory resolution cannot be reached an independent reviewer/consultant will be obtained to perform the analysis and make recommendations. Pending resolution of this issue, Kaiser Engineers Hanford Company (KEH) should evaluate methods for local stress relfef at the location of the riser penetration. In particular, KEH should evaluate non-thermal techniques for stress relief and the feasibility of pre-heating the penetration area instead of post weld heat treatment.

If you have any questions pertaining to the information attached, please call me at 373-1802.

Very truly yours,

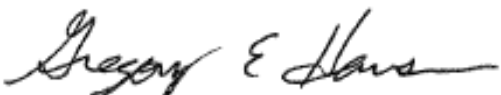

G. E. Hansen, Cognizant Engineer

Waste Management Capital Projects Unit

Support Facilities Group

GEH/raa

Att.

cc: L. E. Johnson, Rockwell Project Engineer $L-1$ 


\section{DON'T SAY IT -- WRITE IT}

To: Greg Hansen

From: Leslie stegen ystegar

Subject: Pump Specifications AP Farm

Date: May 29, 1987

Ref: External Letter, R87-2231, Greg Hansen to J. R. Mills, "SCOPE MODIFICATION TO 107 -AP AND 108-AP RISER/PIT INSTALLATION, DEFINITIVE
DESIGN"

Per Kaisers request, the worst case bending moment and torques which the AP Mixer Pump may experience during operations have been developed. The two worst case scenarios would occur if: one of the nozzles plugged during operations, or the motor rotor locked. The maximum bending moment due to nozzle plugging is $112,050 \mathrm{ft}$. Ibs., and the maximum motor torque due to a locked rotor is $6468 \mathrm{ft}$. 1bs.

The bending moment was calculated assuming that the distance between the top of the pump assembly and the nozzle is 50 feet. If this distance changes then the bending moment will have to be adjusted accordingly. The motor torques were calculated assuming the locked rotor torque is 4 times the normal operating torque and the start up torque is 2 times the normal operating torque. A service factor of 1.15 was added to the normal operating torque prior to making the calculations. Attached are the calculations and assumptions for both the bending moment and the torque.

Other motor torques which may be of interest to Kaiser are:

- $1406 \mathrm{ft}$ lbs, normal operating torque

- $2812 \mathrm{ft}$ lbs, starting torque

Motor Pump Specifications

- $300 \mathrm{HP}$

- 1170 RPM

- 3 phase, 460 volt, TEFC, Class H The entire assembly, pump/motor, column, and rotational assembly will rotate
between .2 and .5 RPM.

cc: A. J. Diliberto 


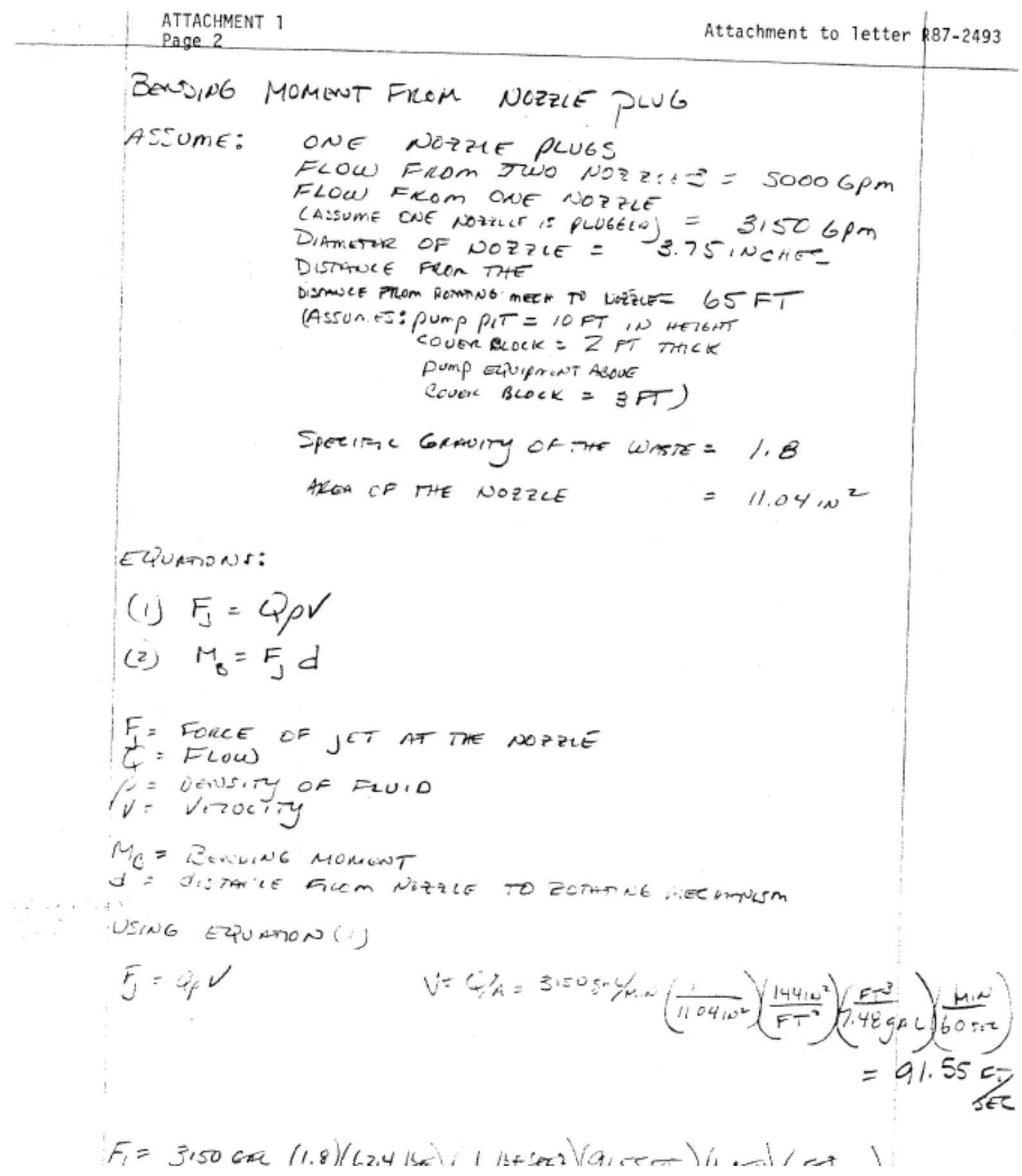


RPP-RPT-55983, Rev. 0

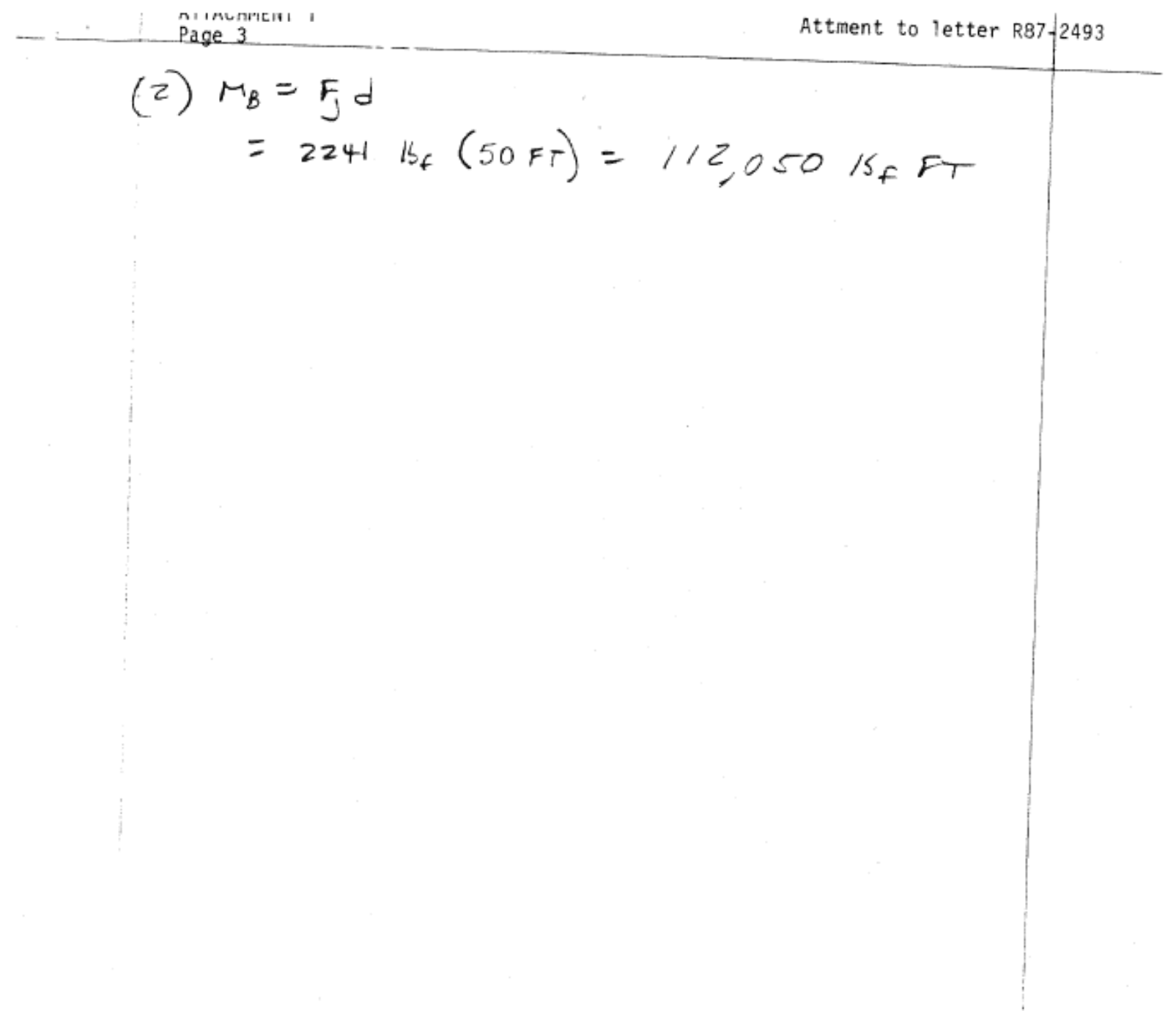


RPP-RPT-55983, Rev. 0

AIIACHMENI 2

Page 1

Attachment to letter R87-2493

$\because \ldots+\cdots+$

G.E. HAISEN

$5 / 27 / 87$

Subject: Stress relief requirements for 107-AP and 108-AP tank risers.

A review of ASME section VIII Div, 2 and construction spec.

241-AP tank farm) has been foriginal spec. for (that some form of stress relief is required for the riser additions to tanks 107-AP and 108-AP.

The orignal construction spec. for the AP tank farm required stress relief following

completion of all high temperature work such as welding, cutting, ect. (Reference attached page from $B-340-C 4$ spec.)

ASME section VIII Div. 2 requires postweld heat treatment in accordance with article $A F=402, A G-301$ (c) and table AF-402.1. (See attached references)

Quality Assurance feels that satisfactory stress relief can be obtained by the use of one of the following: 1. Postweld heat treatment in accordance with table AF-402.

2. Postweld heat treament for a longer period of time at a lower temperature in accordance with table AF-402.2 3. Alternative to postweld heat treatment using a higher preheat temp. $\angle$ 
RPP-RPT-55983, Rev. 0

ATTACHMENT 2

Page 2

Attachment to letter $R 87-2493$

ding area adjacent to the weld and one adjacent to the weld at the of the reading area.

.6 Documentation of Nondestructive Examinations

Rev 1

3.3.6.1 Deliver completed NDE/Weld Record and "As-Built" weld ident if i-

$\operatorname{Rev} 1$ cation drawings to the Government's Representative one day after completion of hydrostatic testing.

3.3.7 Final acceptance of all welds will be by the Government's

Rev 1 Representative.

\subsection{STRESS RELIEVING}

3.4.1 Primary tanks are to be fully stress relieved following completion of all high temperature work such as welding, cutting, gouging, repairs, etc. Heat tanks internally and use indicating and recording temperature devices to aid in control and maintenance of a uniform distribution of temperature in the tank walls and to indicate the pressure within the tank. Insulate tanks for the stress relieving operation; remove insulation after completion of stress relief.

3.4.2 Perform stress relief in accordance with ASME, Section VIII, Division 2, Article F-4, except that:

3.4.2.1 The maximum allowable decrease in temperature below the specified temperature of $1100 \mathrm{~F}$ shall not exceed $100 \mathrm{~F}$.

3.4.2.2 The temperature shall be brought from ambient to $220 \mathrm{~F}$ and held for 6 hours.

3.4.2.3 The rate of temperature rise and reduction between $800 \mathrm{~F}$ and $1100 \mathrm{~F}$ shall be no more than $100 \mathrm{~F} / \mathrm{hr}$.

3.4.2.4 The period of heating from $800 \mathrm{~F}$ to $1100 \mathrm{~F}$ shall consume no more than 12 hours.

3.4.2.5 During the heating-up period, after any recorded temperature reaches $800 \mathrm{~F}$, the temperature of all parts of the tank being heated shall be uniform with a maximum temperature differential at any time of $200 \mathrm{~F}$.

3.4.3 Do not allow direct impingement of flame on any part of the tank. Control gases introduced into the tank during heating and holding periods, so as to avoid excessive oxidation of the interior surface of the vessel.

3.4.4 Perform a stress relieving operation based on a holding temperature of $1100 \mathrm{~F}$ for one hour per inch of metal thickness, that will 
RPP-RPT-55983, Rev. 0

Pagnintors c

Page 3

Attachment to letter R87-2493

\section{ARTICLE F-4 \\ HEAT TREATMENT OF WELDMENTS}

\section{AF-400 HEAT TREATMENT OF WELDMENTS}

\section{AF-401 Requirements for Preheating}

The Welding Procedure Specification for the material being welded shall specify the minimum preheating requirements in accordance with the weld procedure qualification requirements of Section IX. Where preheating is not required by the welding procedure, preheating may be employed during welding to assist in completion of the welded joint. The need for and temperature of preheat are dependent on a number of factors, such as the chemical analysis, degree of restraint of the parts being joined, elevated tempera. ture physical properties, and material thicknesses. Specific rules for preheating are not given in this Division. Some practices used for preheating are given in nonmandatory Appendix D, as a general guide for the materials listed by P-Numbers of Section IX. It is cautioned that the preheating listed therein does not necessarily ensure satisfactory completion of the welded joint, and requirements for individual materials within the P-Number listing may have preheating more or less restrictive than this general guide.

\section{AF-402 Requirements for Postweld Heat Treatment}

Before applying the detailed reguirements and exemptions in these paragraphs, satisfactory qualification of the welding procedures to be used shall be performed in accordance with all the variables of Section IX and AF-321, including conditions of postweld heat treatment or its omission, and the

${ }^{1}$ Additional postweld heat ireatmeat requirements mey result from the requirements of Articie T.2. restrictions listed below. Except for nonferrous materials and except as otherwise provided in Table AF. 402.1 and Table AF-402.2 for ferrous materials, all welded pressure vessels or pressure vessel parts shall be given a postweld heat treatment at a temperature not less than that specified in those Tables when the nominal thickness, including corrosion allowance, of any welded joint in the vessel or vessel parts exceeds the limits in those Tables. The exemptions for postweld heat treatment, as provided for in Tables AF. 402.1 and $A F-402.2$, are not permitted when the vessel is designed for lethal service as defined in footnote 3 to AG-301.1(c) or when welding ferritic materials greater than $1 / 8$ in. thick with the electron beam welding process. The materials in Table AF-402.1 are listed in accordance with QW-422 of Section IX and are also listed in the Tables of stress intensity values in Part AM.

AF-402.1 When Holding Temperatures and Times May Be Exceeded. Except where prohibited in Table AF-402.1, holding temperatures and/or holding times in excess of the minimum values given in Table AF. 402.1 may be used (see AM-202). A time-temperature recording of all postweld heat treatments shall be provided for review by the Inspector. The holding time at temperature specified in Table AF-402.1 need not be continuous. It may be an aceumulation of time of multiple postweld heat treat cycles.

AF-402.2 Heat Treatment of Pressure Parts Consisting of Different P-Number Groups. When pressure parts of two different P.Number groups are joined by welding, the postweld heat treatment shall be that specified in Table AF-402.1 with applicable notes for the material requiring the higher postweld heat treatment temperature. When nonpressure parts are welded to pressure parts, the postweld heat treatment temperature of the pressure part shall control. 
RPP-RPT-55983, Rev. 0

MI I ALחIEIVI C

Page 4

Attachment to letter R87-2493

Tabie AF-402,1

SECTION VIII - DIVISION 2

1986 Edition

TABLE AF-402.1

REQUIREMENTS FOR POSTWELD HEAT TREATMENT OF PRESSURE PARTS AND ATTACHMENTS

\begin{tabular}{|c|c|c|c|c|}
\hline \multirow{2}{*}{ Material } & \multirow{2}{*}{$\begin{array}{l}\text { Normal Hoiding } \\
\text { Temperature, } \\
\text { 'F, Minimum }\end{array}$} & \multicolumn{3}{|c|}{$\begin{array}{l}\text { Minimum Holding Time at Normal Temperature } \\
\text { for Nominal Thickness (See AF-402.1) }\end{array}$} \\
\hline & & Up to 2 in. & Over 2 in. to 5 in. & Over 5 in. \\
\hline $\begin{array}{l}\text { P.No. } 1 \\
\text { Group Nos. } 1,2,3\end{array}$ & 2100 & $\begin{array}{l}2 \mathrm{hr} / \mathrm{in.} \\
1 \mathrm{hr} \\
\text { minimum }\end{array}$ & $\begin{array}{l}2 \mathrm{hr} \text { plus } 15 \mathrm{~min} \\
\text { for each addi. } \\
\text { tional inch over } \\
2 \mathrm{in} .\end{array}$ & $\begin{array}{l}2 \mathrm{hr} \text { plus } 15 \mathrm{~min} \\
\text { for each addi- } \\
\text { tional inch over } \\
2 \mathrm{in.}\end{array}$ \\
\hline
\end{tabular}

NOTES:

(1) When it is impractical to postweld heat treat at the temperature specified in this Table, it is permissible to carry out the postweld hea treatment at lower temperatures for longer periods of time in accordance with Table AF.402.2.

(2) Extept for exemptions in Note (3), postwelo heat treatment is mandatory under the following conditions:
(a) for material over 21 .

$12 / 2$ in. nominal thickness unless preheat is. Postweld heat treatment is mandatory on materials over $11 / 4$ in. nominal thickness through (b) on material of all thicknesses if required by AG-301 a minimum temperature of $200^{\circ} \mathrm{F}$ during weiding. (c) on materia of ail thicknesses if required by AG-301.1(c)

(3) Post weid neas treatment is not mess for pressure parts subject to direct firing.

(a) for groove welds not is not mandatory under the conditions specified beiow:

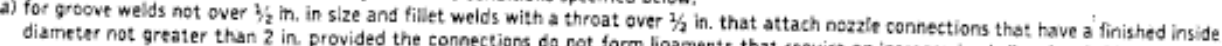
diameter not greater than 2 in. provided the connections do not form ligaments that require an increase in shell or head thickness, ans preheat to a minimum temperature of $200^{\circ} \mathrm{F}$ is applied:

(b) for groove weids not over $1 / 2$ in. in size or fillet welds having a throat thickness of $1 / 2$ in, or less used for attaching noripressure parts to (c) for studs weided to pressure parts provided preheat to a minimum ${ }^{\circ}$ is applied when the thickness of the pressure part exceeds $11 / 4$ in. part exceeds $1 \%$ in.

\begin{tabular}{|c|c|c|c|c|}
\hline \multirow[b]{2}{*}{ Material } & \multirow{2}{*}{$\begin{array}{l}\text { Normal Holding } \\
\text { Temperature, } \\
{ }^{F} \text {, Minimum }\end{array}$} & \multicolumn{3}{|c|}{$\begin{array}{l}\text { Minimum Holding Time at Normal Temperature } \\
\text { for Nominal Thickness (See AF-402.1) }\end{array}$} \\
\hline & & $U_{p}$ to 2 in. & Over 2 in. to 5 in. & Over 5 in. \\
\hline $\begin{array}{l}\text { P.No. } 3 \\
\text { Group Nos. } 1,2,3\end{array}$ & 2100 & $\begin{array}{l}1 \mathrm{hr} / \mathrm{in}, \\
1 \mathrm{hr} \\
\text { minimum }\end{array}$ & $\begin{array}{l}2 \text { hr plus } 15 \mathrm{~min} \\
\text { for each addi- } \\
\text { tional inch over } \\
2 \text { in. }\end{array}$ & $\begin{array}{l}2 \mathrm{hr} \text { plus } 15 \mathrm{~min} \\
\text { for eath addi- } \\
\text { tional inch over } \\
2 \text { in. }\end{array}$ \\
\hline
\end{tabular}

NQTES:

(1) When it is impractical to postweld heat treat at the temperatures specified in this Table, it is permissible to carry out the pestweld heat

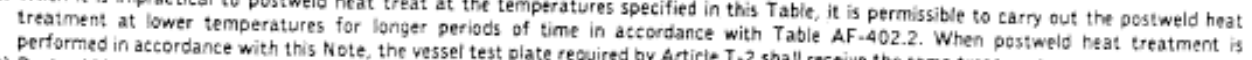

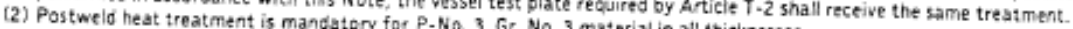

(3) Except for the exemptions in indatery for P-No. 3, Gr. No. 3 material in all thicknesses.

(a) on P.No. 3, Gr. No. 1 and P-No. 3, Gr. No, 2 material oves is mandatory under the following conditions:

mancatory on material up to and 3, Gr. No, 2 material over 3, in, nominal thickness. For these materials, postweld heat treatment is mancatory on material up to and including $\%$ in nominal thickness uniess a weiding procedure qualification described in Af-210.4 has been made in equal or greater thickness than the production weid.

(4) For weiderial in all thicknesses if required by $A G-301.1(c)$ or if for pressure parts subject to direct firing. beiow:

(t) conditions specifief a) for

carocen content, except when further limited by the maximum carbon content of not more than $0.25 \%$ 15A Matepial Specification caroch content, except when further limited by the purchaser to a value within the Specifitation limitst or to nonaressure narts with 
RPP-RPT-55983, Rev. 0

ATTACHMENT 2

Page 5

Attachment to letter R87-2493

1986 Edition

DART AF - FABRICATION REQUIREMENTS

Tables AF-402.1, AF- 402.2

TABLE AF-402.1 (CONT'D)

REQUIREMENTS FOR POSTWELD HEAT TREATMENT OF PRESSURE PARTS AND ATTACHMENTS

\begin{tabular}{|c|c|c|c|c|}
\hline \multirow[b]{2}{*}{ Material } & \multirow{2}{*}{$\begin{array}{l}\text { Normal Holding } \\
\text { Temperature, } \\
{ }^{\circ} \text {, Minimum }\end{array}$} & \multicolumn{3}{|c|}{$\begin{array}{l}\text { Minimum Holding Time at Normal Temperature } \\
\text { for Nominal Thickness (See AF- } 402.1 \text { ) }\end{array}$} \\
\hline & & Ud to 2 in. & Over 2 in. to 5 in. & Over 5 in. \\
\hline $\begin{array}{l}\text { P-No. } 10 B \\
\text { Group No. } 2\end{array}$ & 1100 & $\begin{array}{l}1 \mathrm{hr} / \mathrm{inh}, \\
2 \mathrm{hr} \\
\text { minimum }\end{array}$ & $1 \mathrm{hr} / \mathrm{in}$ & $1 \mathrm{hr} / \mathrm{in}$. \\
\hline
\end{tabular}

NOTES:

(2) Postweid heat treatment is mandatory for P-No. 108 materials for all thickness.

(2) If during the holding period of postweld heat treatment, the maximum time or temperature of any vessel component exceeds the provisions of AM-202, additional test coupons shall be made and tested.

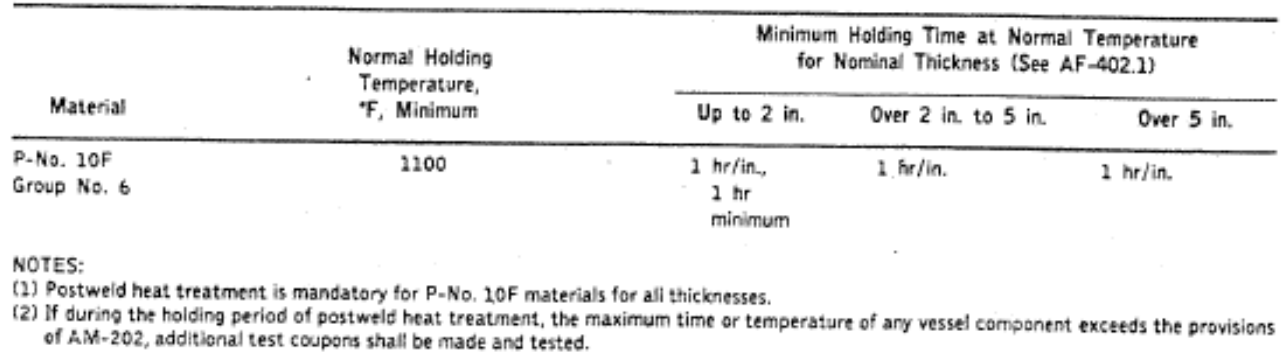

TABLE AF-402.2

ALTERNATIVE REQUIREMENTS FOR POSTWELD

HEAT TREATMENT OF PRESSURE PARTS AND ATTACHMENTS1

\begin{tabular}{cc}
\hline $\begin{array}{c}\text { Decrease in } \\
\text { Temperature Below } \\
\text { Normal Holding } \\
\text { Temperature, " } F\end{array}$ & $\begin{array}{c}\text { Minimum } \\
\text { Time at Decreased } \\
\text { Temperature, } \\
\text { ar/in. of Thickness }\end{array}$ \\
\hline 50 & 2 \\
100 & 3 \\
150 & 5 \\
200 & 10 \\
\hline
\end{tabular}

NOTE:

(1) Postweid heat treatment at lower temperatures for longer periods of time, in atcordance with this Table, shall be used only where permitted in Table AF-402.2. 
RPP-RPT-55983, Rev. 0

AI IRLHMENI 2

Page 6

Attachment to letter R87-2493

\section{ARTICLE G-3 RESPONSIBILITIES AND DUTIES}

\section{AG-300 GENERAI}

The various parties, i.e., User, Manufacturer, and Inspector, involved in the work of producing vessels under this Division, have definite responsibilities or duties in meeting Code requirements. The responsibilities set forth hereinafter relate only to Code compliance and are not to be construed as involving contractual relations or legal liabilities.

\section{AG-301 USER'S RESPONSIBILITY}

AG-301.1 User's Design Specification. It is the responsibility of the user or an agent ${ }^{1}$ acting on his behalf, who intends that a pressure vessel be designed, constructed, tested, and certified to be in compliance with these rules, to provide or cause to be provided for such vessel or vessels a User's Design Specification. This shall set forth requirements as to the intended operating conditions in such detail as to constitute an adequate basis for selecting materials and designing, fabricating, and inspecting the vessel or vessels as required to comply with these rules. The User's Design Specification shall include the method of supporting the vessel (see AD-110).

(a) It is the user's responsibility to specify, or cause to be specified, whether or not a fatigue analysis of the vessel shall be made for cyclic service, ${ }^{2}$ and, when a fatigue analysis is specified, to provide, or cause to be provided, information in sufficient detail so that an analysis for cyclic operation (see also 5-102) can be carried out in accordance with Appendix 5. If the User's Design Specification lists expected operating conditions for which the service evaluation rules in

'Wherever user appears in this document, it may be considered to apply also to an agent acting in bis betalf.

${ }^{2}$ AD- 160 covers the evaluation of service conditions to establish the need of a vessel fatigue analysis as provided by Appendix 5 .
AD-160 indicate need for a fatigue analysis, then such fatigue analysis shall be mandatory and shall be incorporated in the Manufacturer's Design Report. If the User's Design Specification states that no fatigue analysis is required, the Design Specification shall include a statement that the intended vessel operation satisfied the requirements of AD- 160 .

(b) It is the user's responsibility to specify, or cause to be specified, whether or not a corrosion and/or erosion allowance shall be provided, and, if so, the amount.

(c) When a vessel is to contain fluids of such a nature that a very small amount mixed or unmixed with air is dangerous to life when inhaled, it shall be the responsibility of the user and/or his designated agent to determine if it is lethal. ${ }^{3}$ If determined as lethal, the user and/or his designated agent shall so state in the User's Design Specification. It shall be the responsibility of the Manufacturer to comply with the applicable Code provisions [see AM-204, Table AD. 155.1, AF-402, and AF-820(d)].

(d) The User's Design Specification need not provide information other than that required in $\mathrm{AG}$ 301.1, AG-301.1(a), AG-301.1(b), and AG-301.1(c).

AG-301.2 Certification of User's Design Specification. A professional engineer, registered in one or more of the States of the United States of America or the Provinces of Canada and experienced in pressure vessel design, shall certify to the compliance of the User's Design Specifications with the above requirements.

${ }^{3}$ By lethol fubstances afe meant poisonous gaves of liquids of such a nature that a very small smount of the gas or of the vapor of the biquid mixed or unmixed with air is dangerous to life when inhaled. For purposes of this Division, this class includes subsiances of this nature which are stored under pressure of may 
RPP-RPT-55983, Rev. 0

\section{App. Figure A-4. Project W-E01 Completion}

\section{(2. Westinghouse}

P.O. Box 1970 Richland, WA 99352

September 30, 1988

Mr. R. E. Gerton, Director Waste Management Division

U.S. Department of Energy

Richland Operations Office

Richland, Washington 99352

Dear Mr. Gerton:

COMPLETE TANK 107-AP NEW RISER INSTALLATION TO ALLOW DEMONSTRATION OF DOUBLE-SHELL WASTE RETRIEVAL

This letter reports completion of the U.S. Department of Energy -

Richland Operations Office control led milestone to "Complete Tank 107-AP New Riser Installation to Allow Demonstration of Double-Shell Tank Waste Retrieval." Because of the large costs associated with work done on a contaminated tank, the riser installation has been performed prior to waste transfers into the tank.

Riser and pit installation activities on this tank have been completed, as of the close of business on September 30, 1988. A new riser was added to the tank, the two existing construction risers were modified and new mixer pump pits were installed on each of these three risers. Shielding plugs have been placed in the three 42-inch risers. Some painting, backfilling, site stabilization and the removal of the temporary fence are construction exceptions which will be completed in early October 1988. Demonstration of prototype retrieval equipment will be completed as an outyear activity.

If you have any questions, please contact Mr. K. W. Owens of my staff on 3-1632.

Very truly yours,

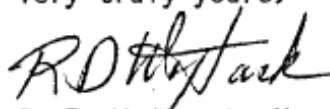

R. D. Wojtasek, Manager

Defense Waste Program Integration

Defense Waste Management Division

peb

DOE-RL - R. D. Izatt

A. W. Kel logg 


\section{App. Figure A-5. Project W-E01 Concrete Demolition Demonstration}

\section{KAISER \\ ENGINEERS \\ HANFDRD}

INTEROFFICE MEMORANDUM

то

Distribution

copies to S. W. Bork

C. J. Denson

E. A. Dukleth

Y. Ingram
D. S. Mager

C. D. Maxson

T. A. Przbylski

JRM File
Dare October 30, 1987

Fnom J. R. Mills Jrem

Project Management

SUEJECT

ER-1081, 107-AP AND 108-AP TANK RISER/PIT INSTALLATION - SITE DEMONSTRATION

A demonstration of the demolition technique and equipment for concrete removal proposed for use on the subject project will be performed Wednesday, November 4, 1987, beginning at 9:00 a.m. at A-Farm in the 200E Area. The equipment will be rented from Advanced Mining and Construction System, Inc. (AMAC, Inc.) from Kent, Washington and delivered to the site Monday, November 2, 1987. The equipment will be available to Construction Forces personnel to operate in demolishing a concrete mockup, in many ways similar to the concrete to be removed during construction. The demonstration is planned to be video taped and circulated for viewing by any interested parties, (engineering, construction, demolition, etc.).

My thanks to Construction Forces (D. J. Heberlein, H. L. Maygra and R. Kelso-Weatherly) and Purchasing (D. D. Mcdonald, A. M. Prindiville and S. 0. Stecker) for their help in putting this demonstration together on such short notice.

JRM: 1bm

Distribution: D. J. Heberlein

R. M. Iten

R. Kelso-Weatherly

H. L. Maygra

D. D. Mcdonald

A. M. Prindiville

S. 0. Stecker

T. L. Walton 
RPP-RPT-55983, Rev. 0 
App. Figure B-1. Nonconformance Report B-340-33

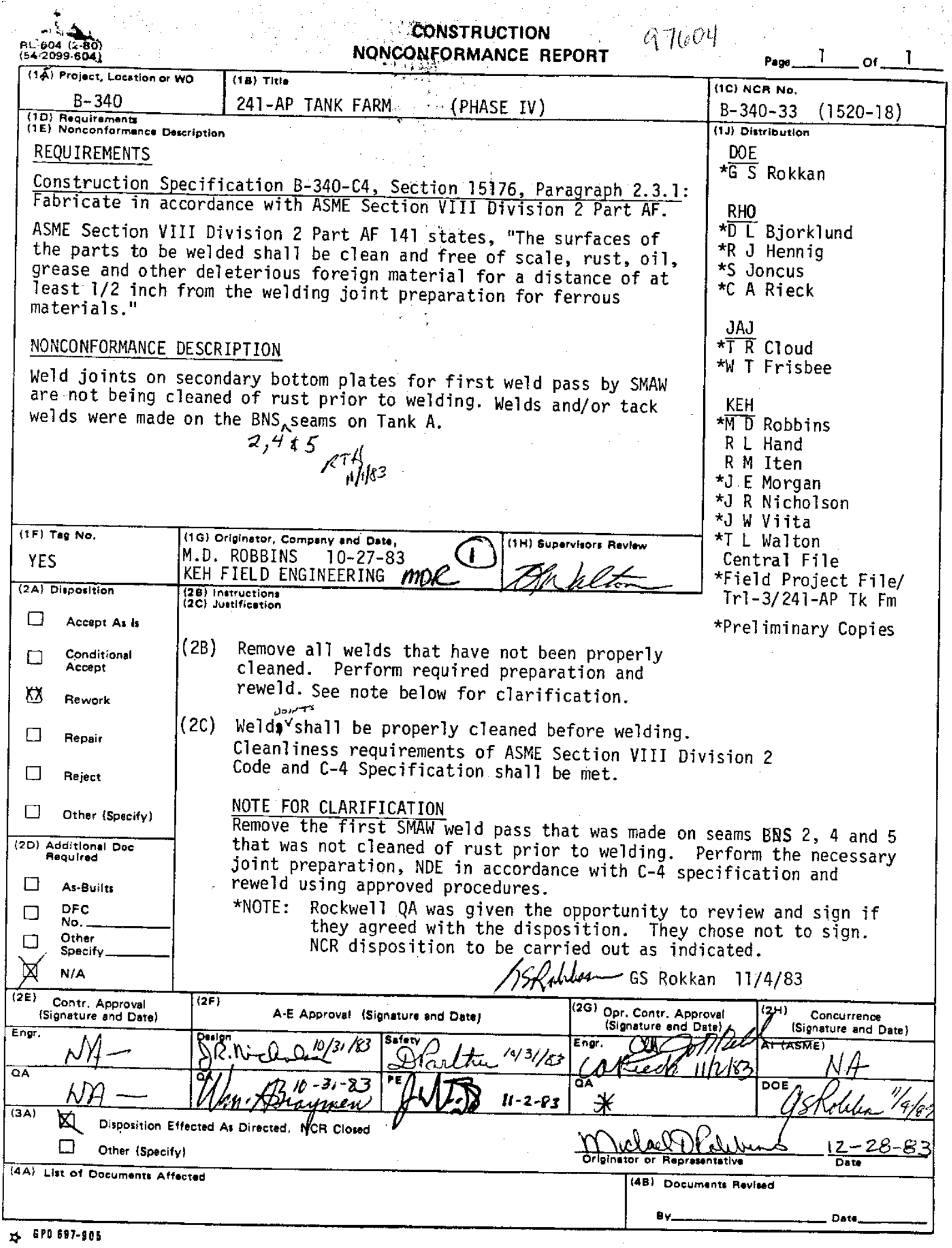




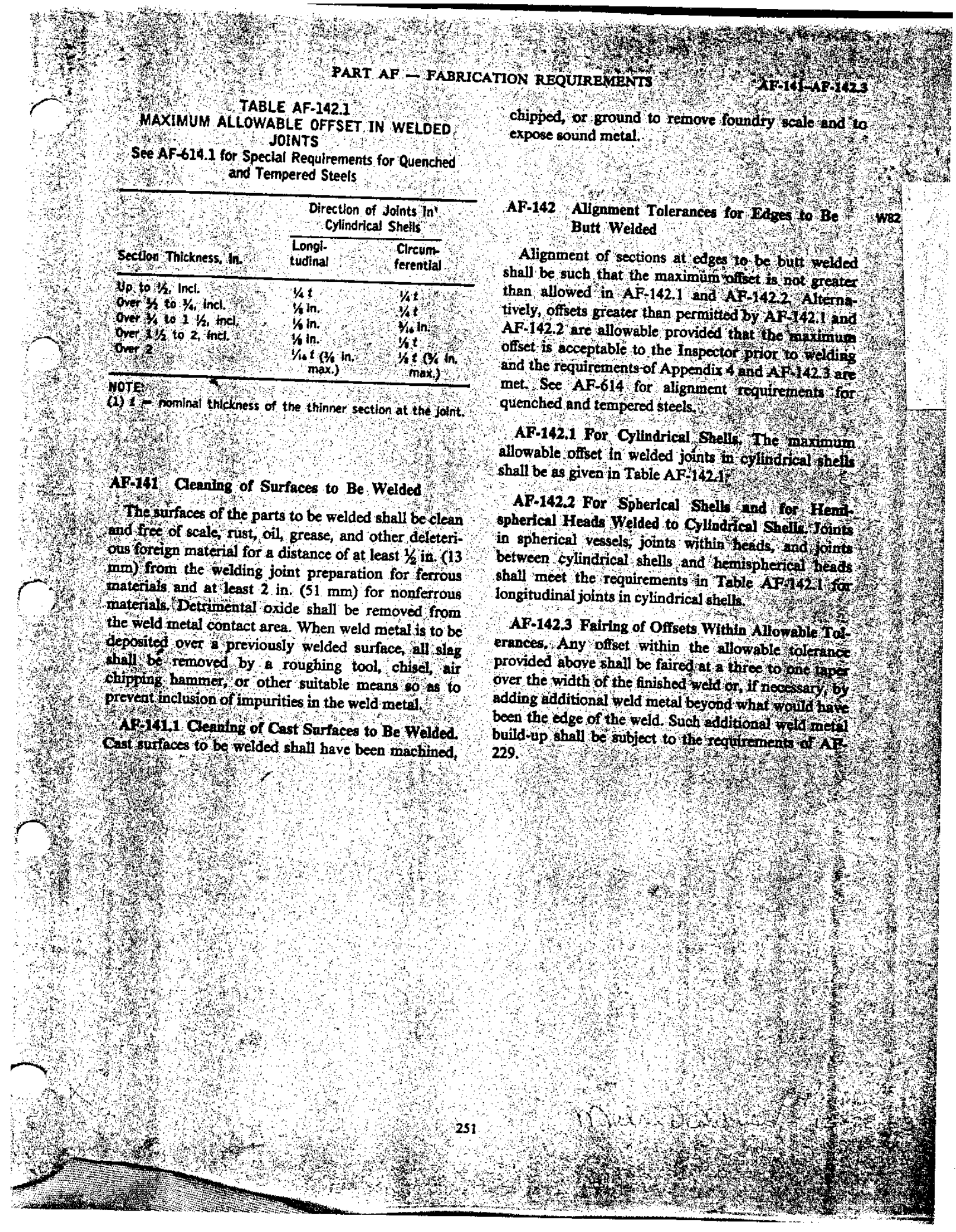


RPP-RPT-55983, Rev. 0

boto that a . Iv
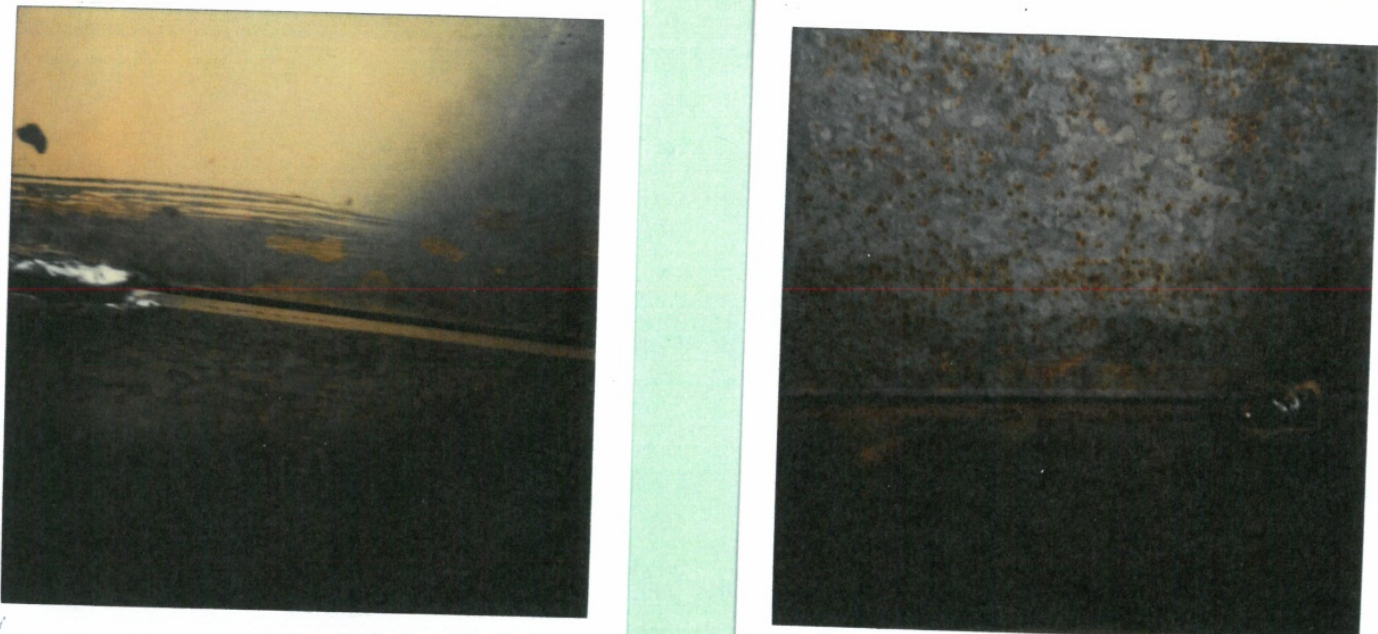

$20340-33$

NCR B340-33 
RPP-RPT-55983, Rev. 0

App. Figure B-2. Nonconformance Report B-340-34

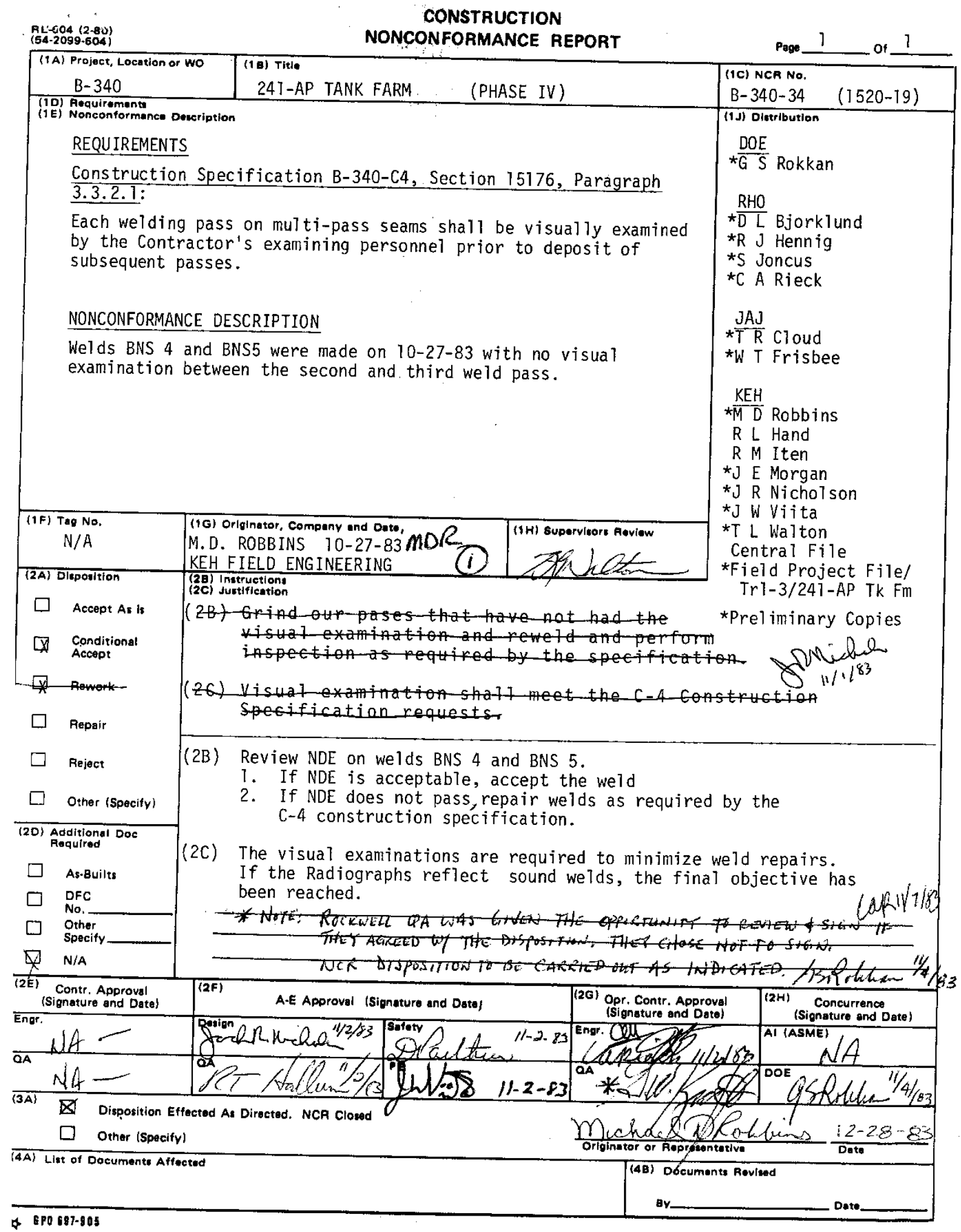


RPP-RPT-55983, Rev. 0

App. Figure B-3. Nonconformance Report B-340-58

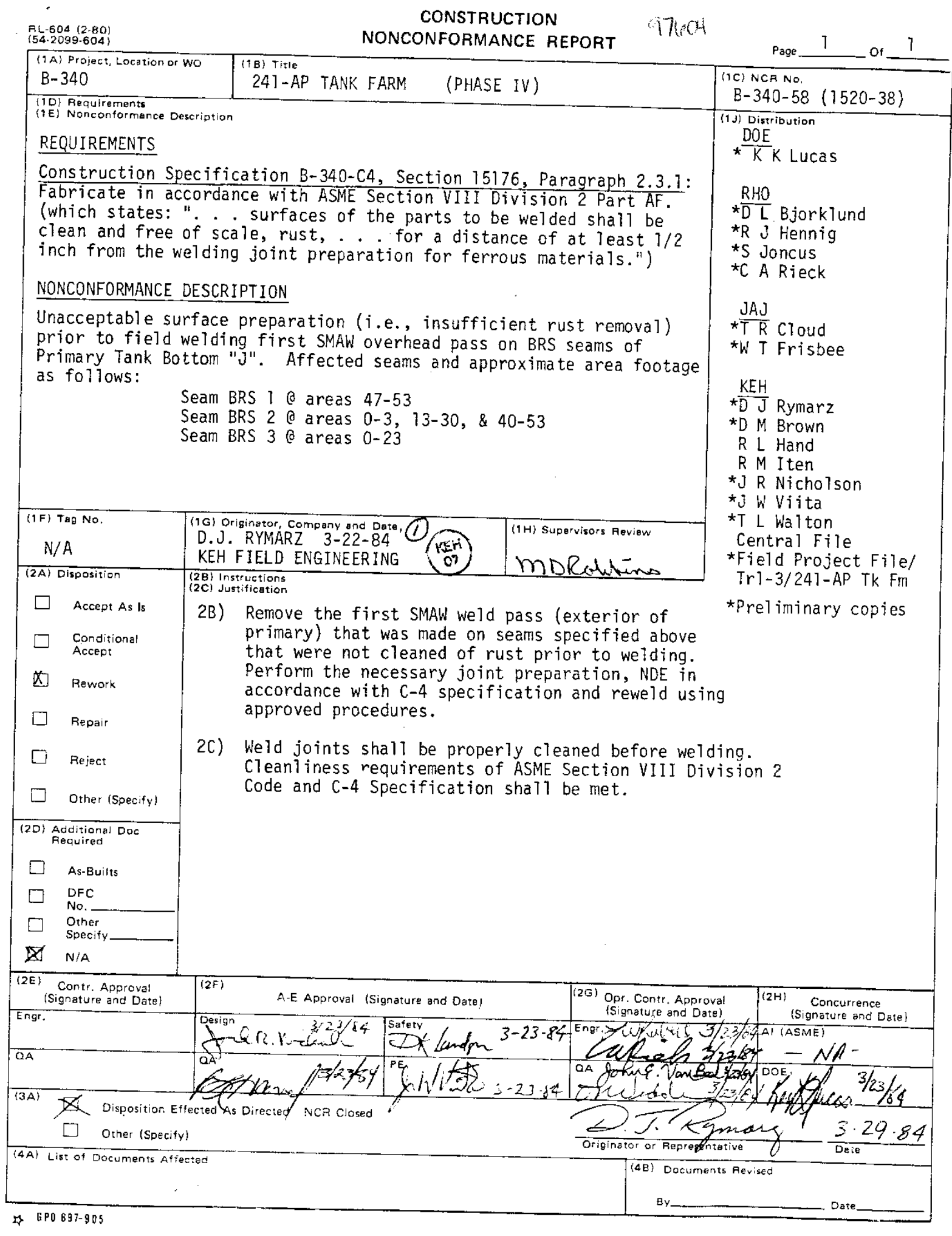


RPP-RPT-55983, Rev. 0

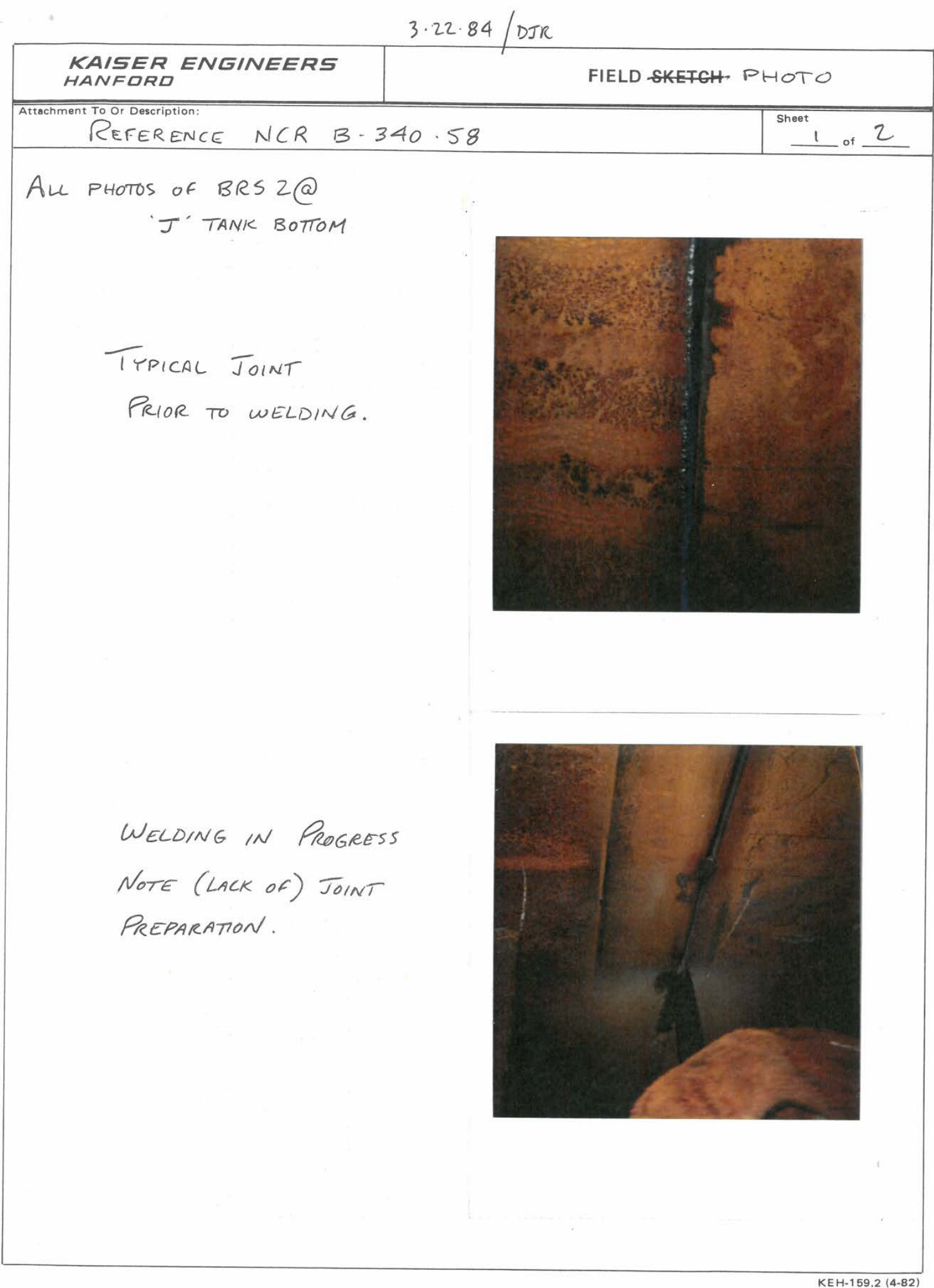


RPP-RPT-55983, Rev. 0

$3 \cdot 22 \cdot 84$ DJR

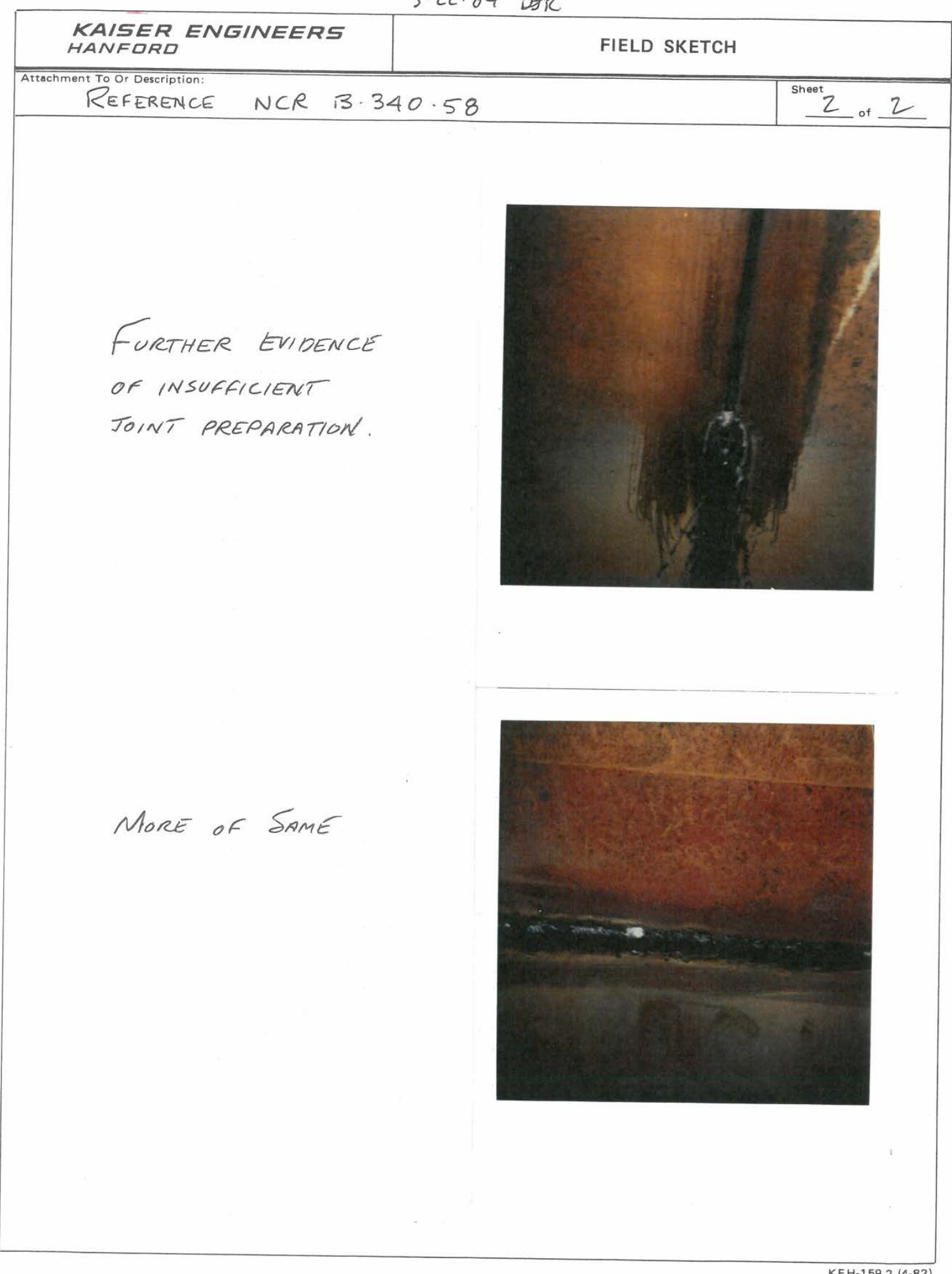

KEH-159.2 (4-82) 
RPP-RPT-55983, Rev. 0

\section{App. Figure B-4. Nonconformance Report B-340-61}

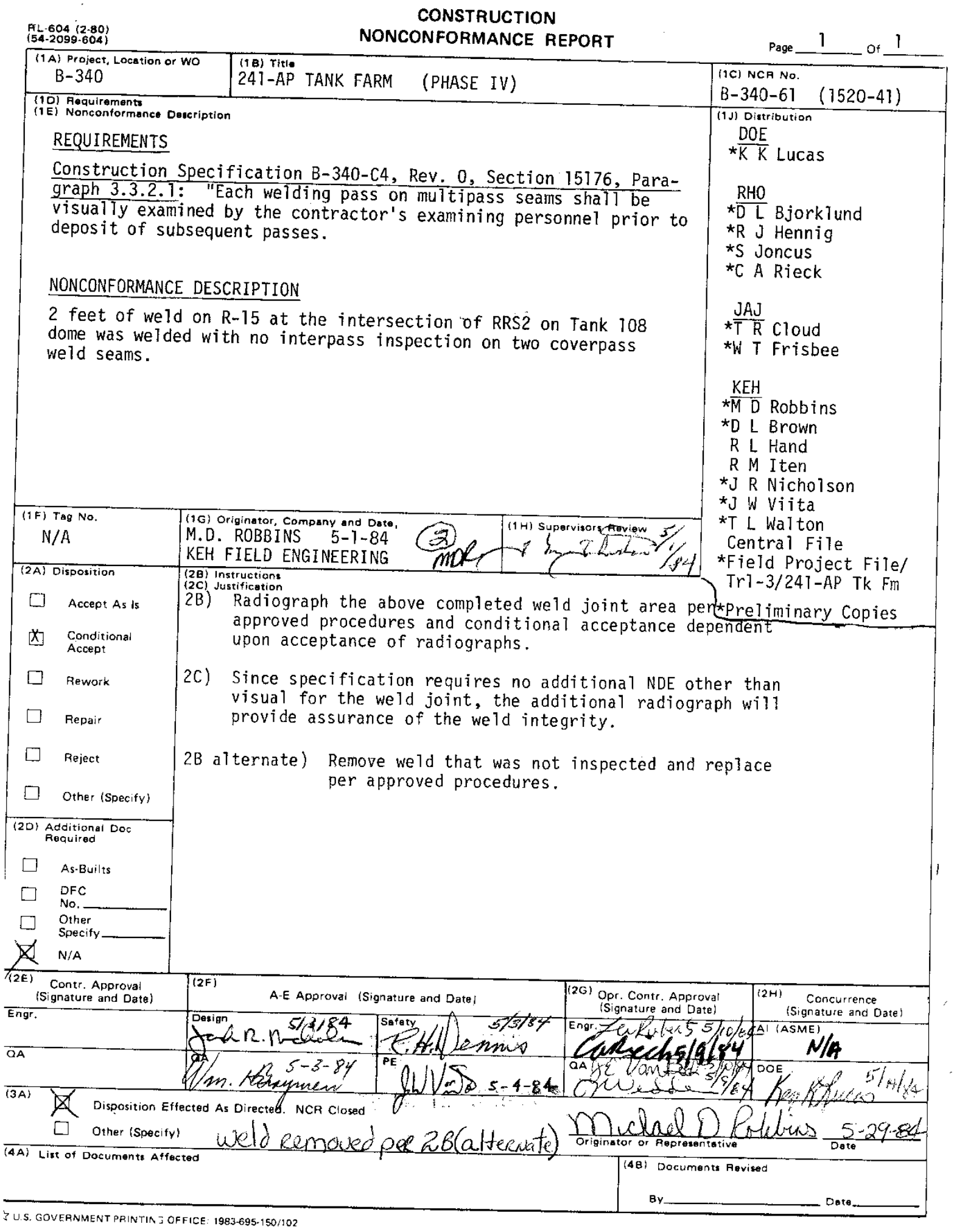


RPP-RPT-55983, Rev. 0

App. Figure B-5. Nonconformance Report B-340-62

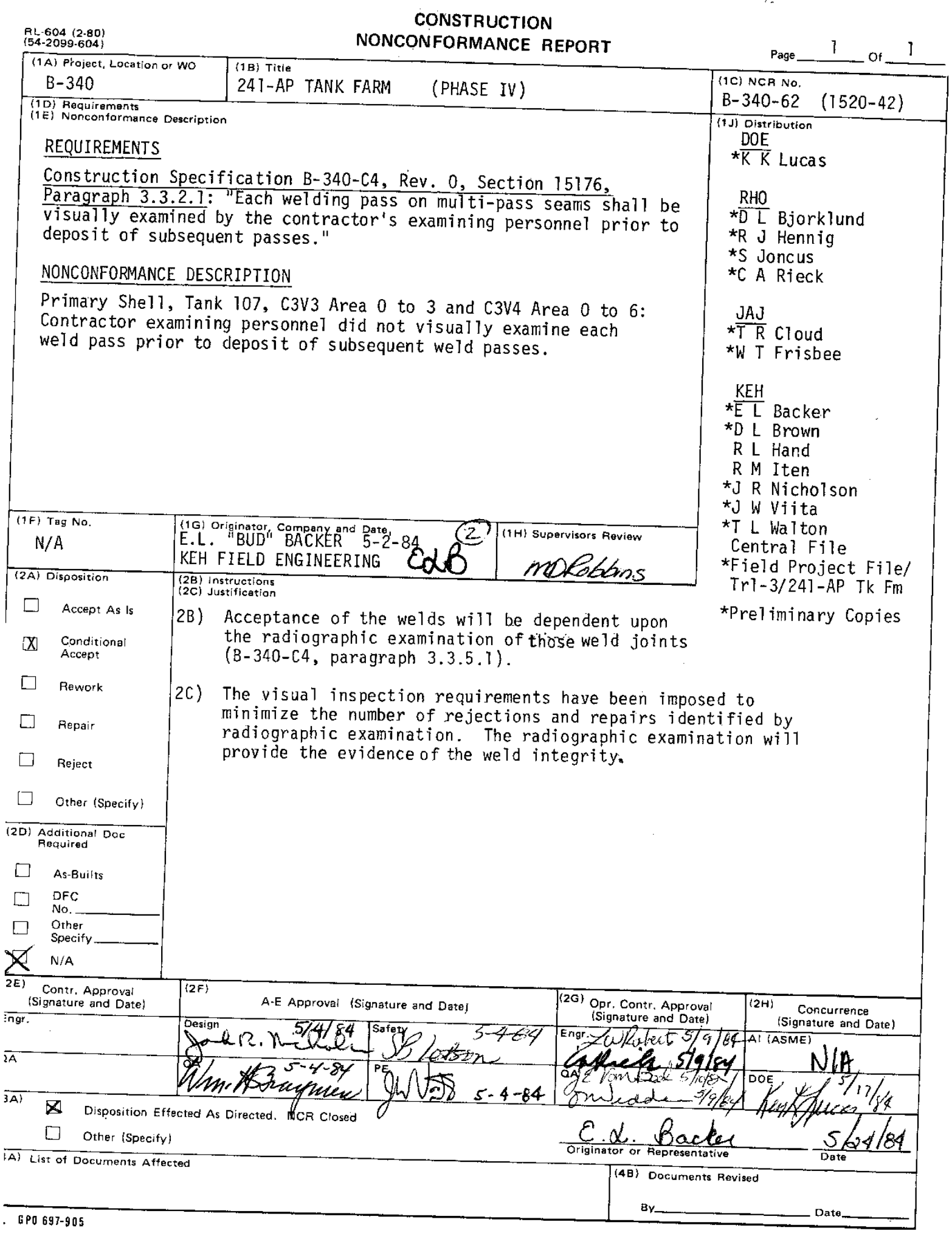


RPP-RPT-55983, Rev. 0

App. Figure B-6. Nonconformance Report B-340-63

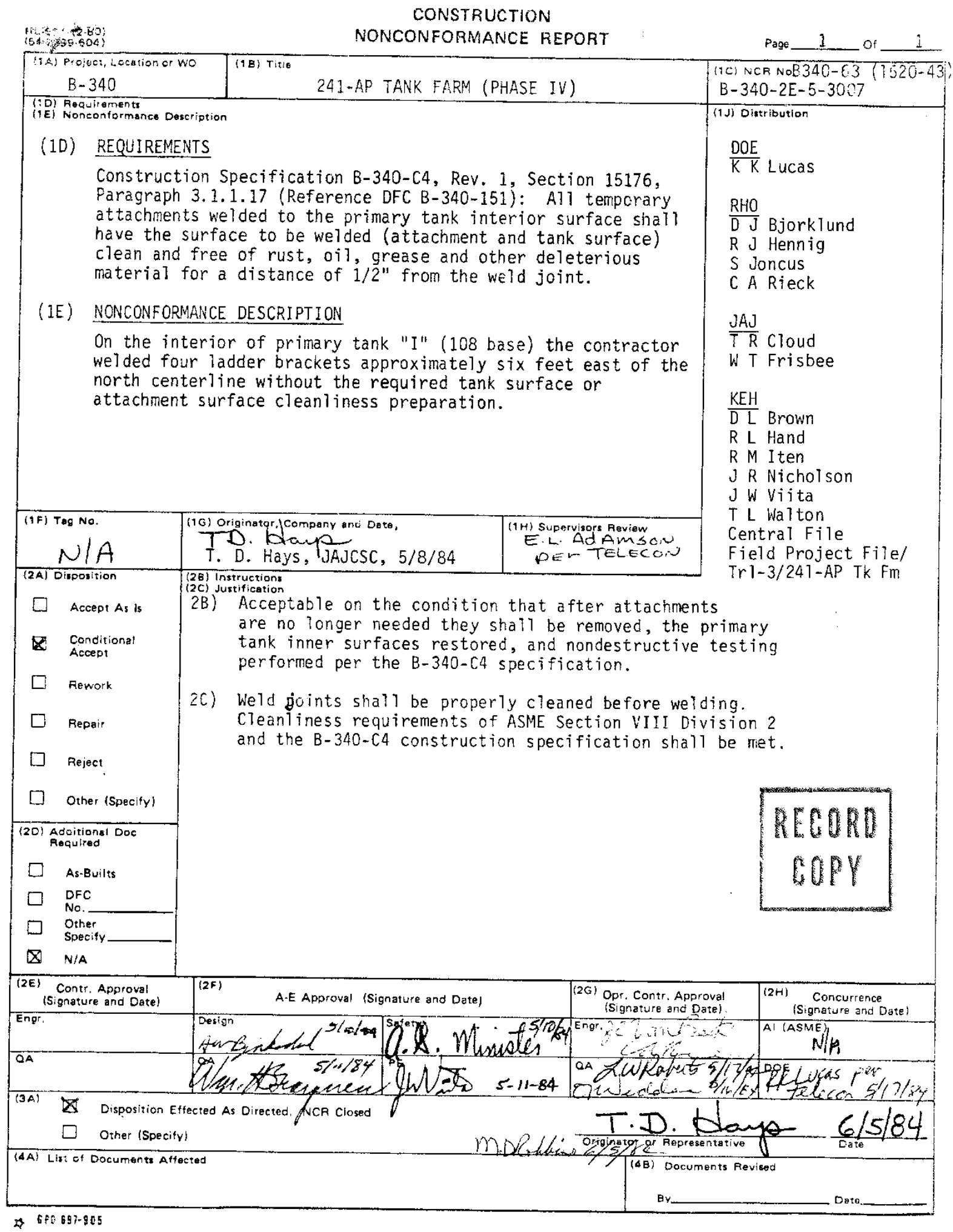


RPP-RPT-55983, Rev. 0

App. Figure B-7. Nonconformance Report B-340-66

RL-604 $(2-80)$
$(54-2099-604)$

CONSTRUCTION

(1A) Project

NONCONFORMANCE REPORT

B- 340

(10) Requirements

REQnconformance Description

REQUIREMENTS

Construction Specification B-340-C4, Section 15176:

I. Paragraph 3.1.1.5 (per DFC \#22): ". : . cIips, lugs, etc., welded to plates. . may not be welded to internal primary tank surface except with prior approval by the Government's Representative."

II. Paragraph 3.1.1.17 (per DFC \#151): "A11 temporary attachments welded to the primary tank internal surface shalt have the surface to be welded (attachment \& tank surface) clean and free of rust, from the weld joint."

NONCONFORMANCE DESCRIPTION

At Primary Tank "0", Course 1 vertical weld seams CIV4 \& CTV5:

I. 2 internal surface attachments at each seam welded wi thout prior approval of Government's Representative. (Approval was given for 4 attachments per seam - 6 attachments were welded per seam.)

II. 6 internal surface attachments at ClV4 welded without surface(s) preparation, i.e., rust not removed.

\begin{tabular}{|l|l|l|}
\hline (1F) Tag No. & (1G) Originator, Company and Date, \\
N/A & D.J. RYMARZ 5-16-84 \\
& KEH FIELD ENGINEERING & (1H) Supervisors Reviow \\
\hline (2A) Disposition & (2B) instructions & M \\
\hline
\end{tabular}

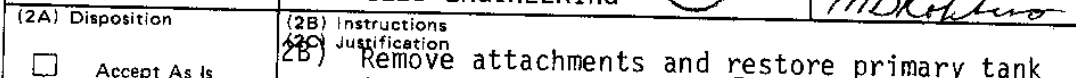

[.] Accept As is

[. Conditional

Rework inner surfaces to origianl shape and contour. Perform
nondestructive testing on the attachment area per specification. (nary Copies

2C) I. Attachment welds to the inside of the primary tank require approval by the governments representative prior to welding.

$\square \quad$ Repair

[] Reject

II. Attachment welds shall be properly cleaned before welding. Cleanliness requirements of Asur of C-4 specification shall be met.

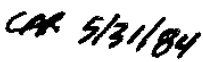

Other (Specify)

(2D) Additional Doc

Required

As-Builts

DFC

No.

Other

Specify

N/A

(2E) Contr. Approval (Signature and Date)

$\overline{Q A} \ldots \ldots$

3A) X Disposition Effected As Directed NCR Closed

$\square$ Other (Specify)

4A) List of Documents Affected 
RPP-RPT-55983, Rev. 0

App. Figure B-8. Nonconformance Report B-340-70

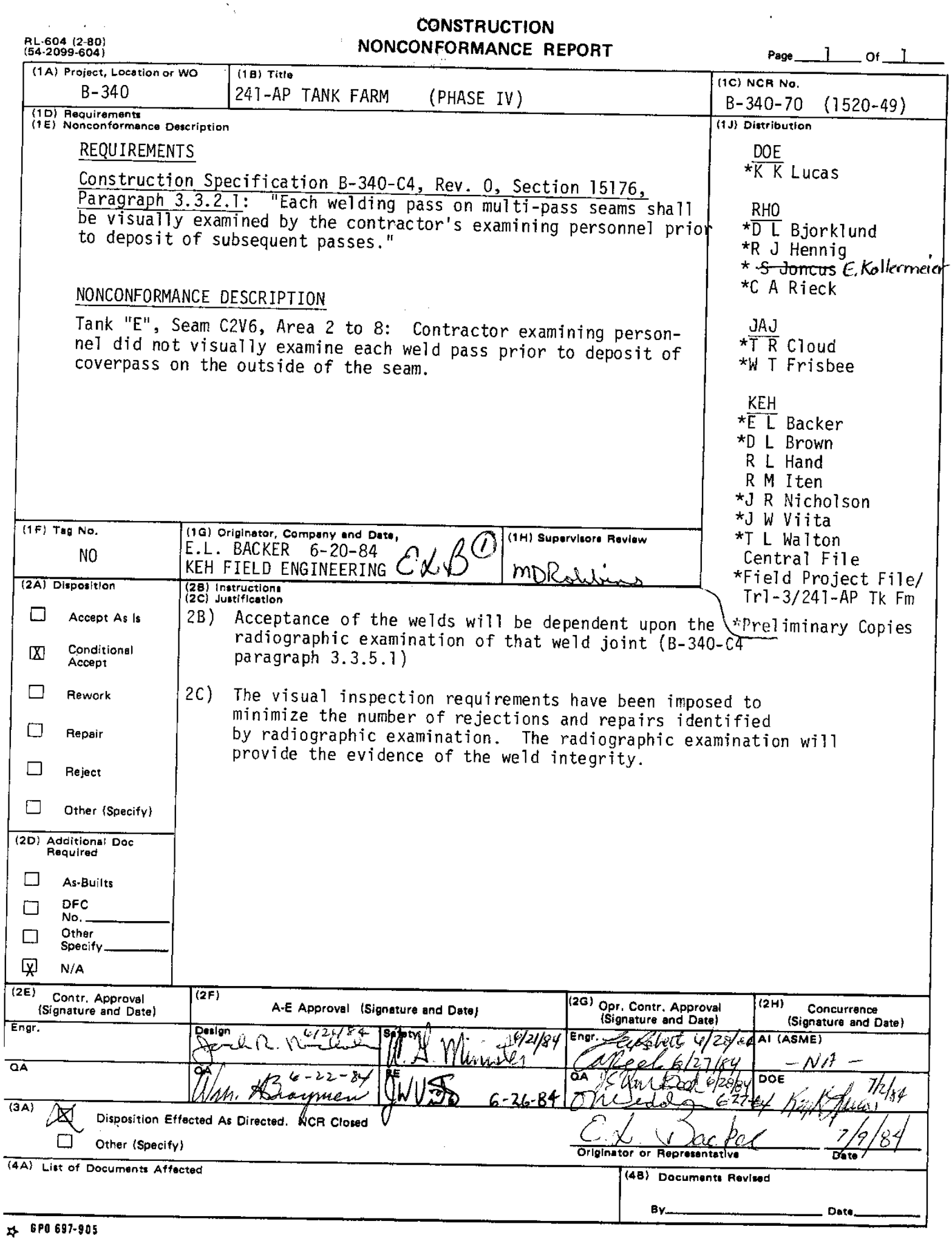


App. Figure B-9. Memorandum Regarding Welding Surface Preparation

\section{KAISER \\ ENGINEERS \\ HANFORD \\ INTEROFFICE MEMORANDUM}

To J.W. VIITA

AT

COPIES TO
G. W. HAHN
R. L. HAND
G. P. OSBORNE
FILE/LB
CENTRAL FILES $\because \quad$ soв no. B-340
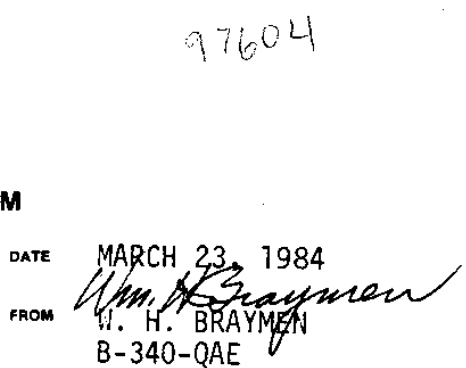

SUAJEC PROJECT B-340 AP TANK FARM "WELDING OVER RUST"

According to NCR B-340-58 we are still experiencing problems in the field with the contractor welding over rust. Also, the Title III inspector informs me that it is a daily trouble area.

Since the contractor has elected to ignore his agreement to clean the plate surfaces in a manner that has been demonstrated to him, it is obvious that corrective action measures are in order. Therefore a letter from KEH QA Manager is being forwarded to JAJ QA Corp. Manager for a corrective action and response.

Also, in the interest of the assurance of welding Oulity, the KEH QA Department feels that we are bound to initiate quality measures which will bring this problem under control. This measure appears to be that the inspection plan for the Tank Construction Phase be amended to include a hold-point for Title III inspection to verify that plate welding surfaces have been properly cleaned prior to welding. Please initiate a DFC which will institute this measure.

WHB $/ \mathrm{s} I \mathrm{~W}$ 
RPP-RPT-55983, Rev. 0

App. Figure B-10. Nonconformance Report B-340-76

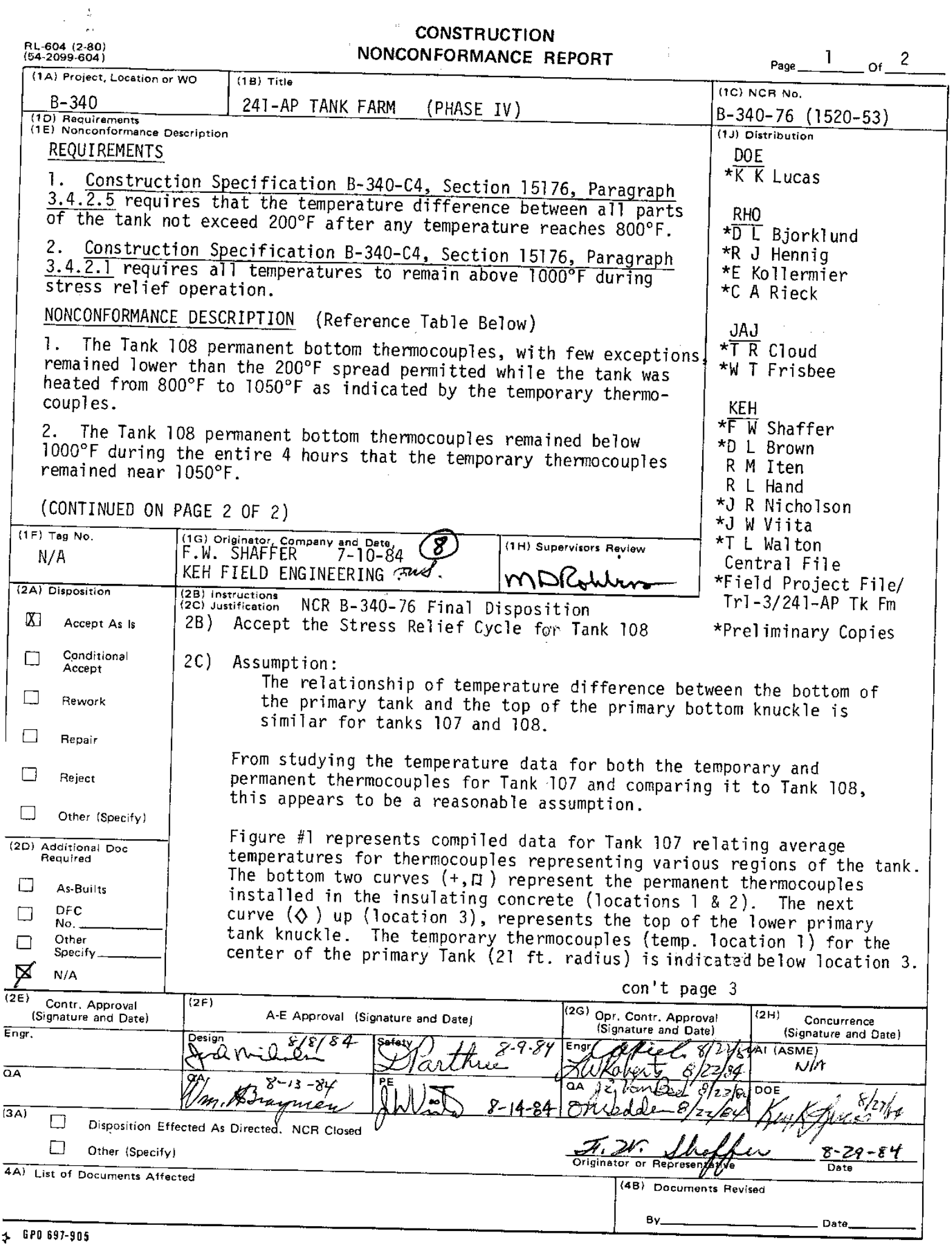


RPP-RPT-55983, Rev. 0

NCR B-340-76

PAGE 2 OF 4

NONCONFORMANCE DESCRIPTION (continued)

NOTE: On 7-6-84 at $2100 \mathrm{hrs}$. the permanent tank bottom thermocouples averaged $265^{\circ} \mathrm{F}$ while the lower side thermocouples averaged $375^{\circ} \mathrm{F}$ and the remaining side and top thermocouples averaged $475^{\circ} \mathrm{F}$. At that time, a portable thermo couple was inserted through the mineral wool insulation until it contacted the tank base, below the knuckle, at the refractory foundation. This thermocouple indicated $400^{\circ} \mathrm{F}$. It was then connected to recorder $\# 5$, and recorded through the remainder of the stress relief operation. Data Transmittal \#1520-A48 contains the entire heat treat temperature
records.

Bottom $\mathrm{T} / \mathrm{C}$

Heatup Temps

I/C \# 7-7-84 $1300 \mathrm{hrs}$.

1

2

3

4

4

5

6

7

8

9

10

11

12

13

14

15

16

17

18

19

20

21

22

23

24

Highest Side T/C: 975

705

720

740

745

725

750

775

680

720

660 low

660

745

690

720

800

695

805 high

760

680

770

740

735

760

750
Bottom $T / C$

Stress Relief Temps

7-7-84 $1830 \mathrm{hrs}$.

860

880

900

895

870

900

890

825

870

860

850

855

890

900

935

875

950

910

855

910

890

865

920

915

Avg. Side/Top Temp: 1049 
RPP-RPT-55983, Rev. 0

NCR B-340-76

Page 3 of 4

Figure \#2 represents the data for Tank 108.

From the temperatures recorded on the bottom of Tank 107 by the temporary and permanent thermocouples, it is evident that the permanent thermocouples are not giving an accurate reading of the tank steel temperatures during stress relief. To determine if Jank 108 was at sufficient temperature for a sufficient period of time to relieve the tank stresses, we compare the results shown in figures 1 and 2 .

To align both curves the point at which the stress relieving operation starts is approximately 12 hours for Tank 107 (figure 1) and approximately $23-1 / 2$ hours
for Tank 108 (figure 2).

The curve (figure 2) identified as "Primary Bottom (TK 107 Related)" represents the temperature difference between the temporary thermocouples on the inside primary bottom and the primary tank bottom knuckle for Tank 107 from the start of the stress relieving cycle superimposed on the Tank 108 temperature time history. As indicated, the Tank 108 bottom did not maintain the $1000^{\circ} \mathrm{F}$ requirement for the three hour minimum time in accordance with the specification and ASME Section VIII, Div. II, Table AF-402.2.

Tab Te AF-402.2 allows a decrease in temperature of $150^{\circ} \mathrm{F}$ below the normal stress relieving temperature of $1100^{\circ} \mathrm{F}$ if the holding time is increased to five hours per inch of material thickness. Figure 2 shows that the temperature differential relationship between Tank 107 and 108 (TK 107 related curve in fig 2 ), that the temperature of Tank 108 remained above $950^{\circ} \mathrm{F}$ in excess of the minimum five hour holding time required by the Code.

In addition, the 1 ine labeled TEMPORARY THFRMOCOUPLE "A" on figure 2 shows the temperatures recorded by the single temporary thermocouple installed near the bottom of the lower knuckle during stress relief of Tank 108.

Although the permanent thermocouples did not perform as expected during stress relief it is felt that they will perform as intended during operation of the tanks. The temperature readings of The permanent thermocouples were gradual1y closing in on the readings given by the temporary thermocouples. Given sufficient time they would have converged (see figures 1 and 2). During operation (1) the temperatures will not be as high as those of the stress relief, (2) they will be held for periods of days, weeks and months not minutes, and (3) they will not be subject to rapid changes of $100^{\circ} \mathrm{F}$ per hour.

The design installation of the permanent bottom thermocouples (Drawing $\mathrm{H}-2-90465$ Sh 2 Section B) probably is the cause of the problem. The steel "can" that the thermocouple is mounted in is probably conducting heat away from the thermocouple and into the refractory. Combined with the fact that the "can" is not fixed to the tank bottom (there could even be an air gap if the bottom has a wave in it) could easily result in temperature readings from the thermocouple lower that that actually seen by the bottom steel. As the refractory heats up this difference will decrease. 
RPP-RPT-55983, Rev. 0

NCR $B-340-76$

Page 4 of 4

In conclusion; it is doubtful from the data available that Tank 108 met the minimum specification requirement for stress relief of $1000^{\circ} \mathrm{F}$

for three hours but the code option of $950^{\circ} \mathrm{F}$ for five hours has been met and the tank stress relief can be accepted on that basis. The permanent thermocouples did not perform as intended during stress relief but should perform as intended during tank operations. 
RPP-RPT-55983, Rev. 0

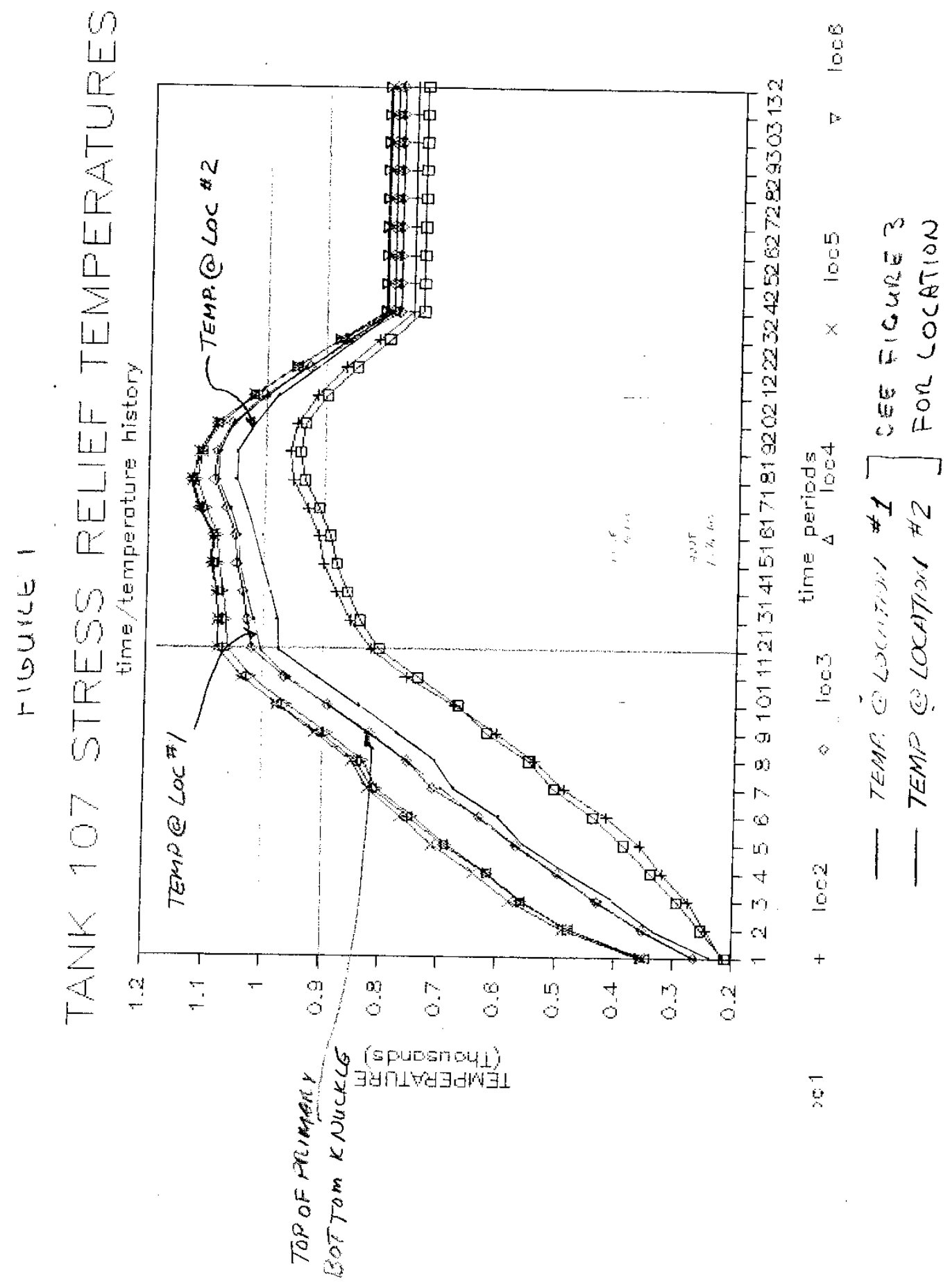


RPP-RPT-55983, Rev. 0

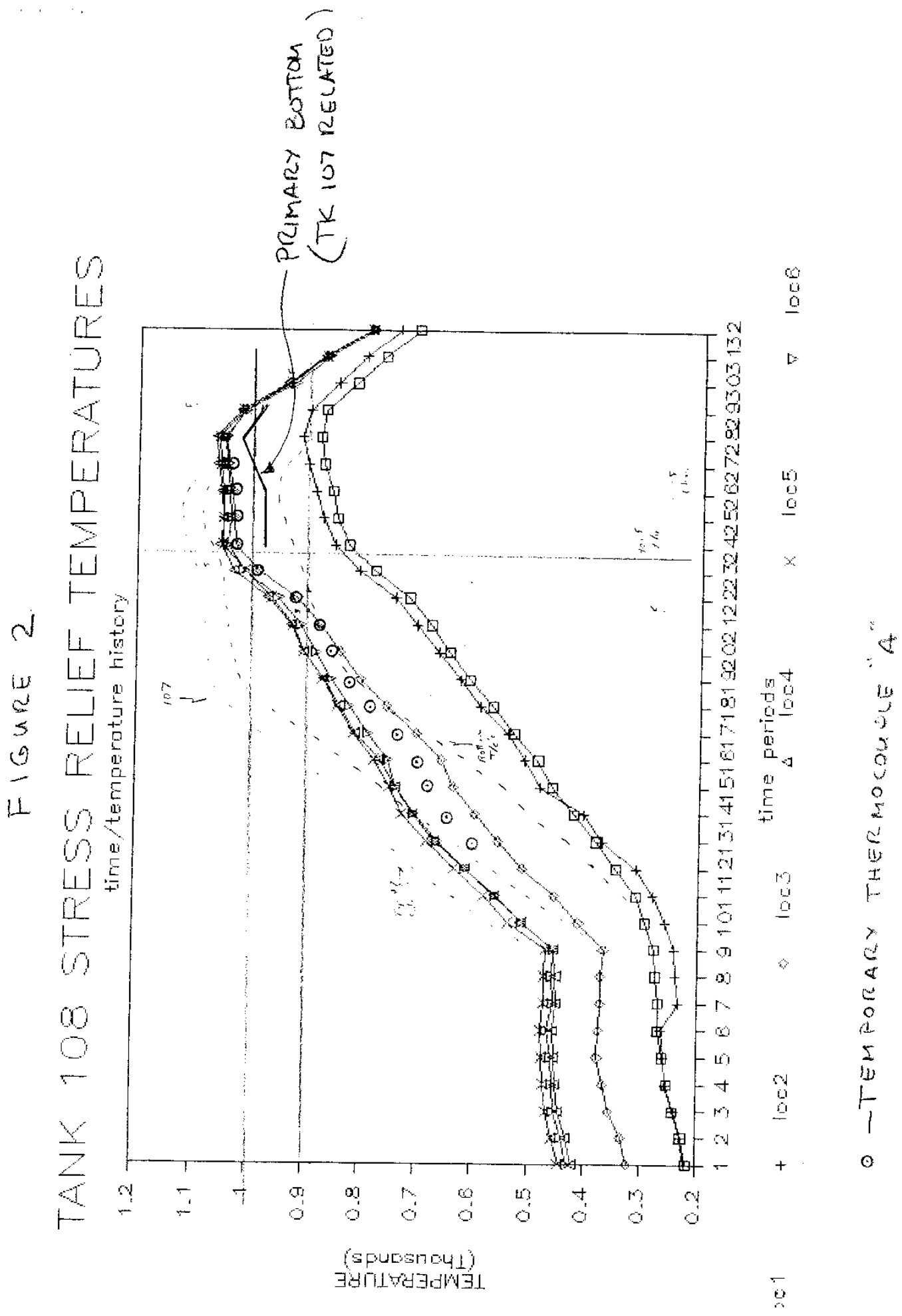




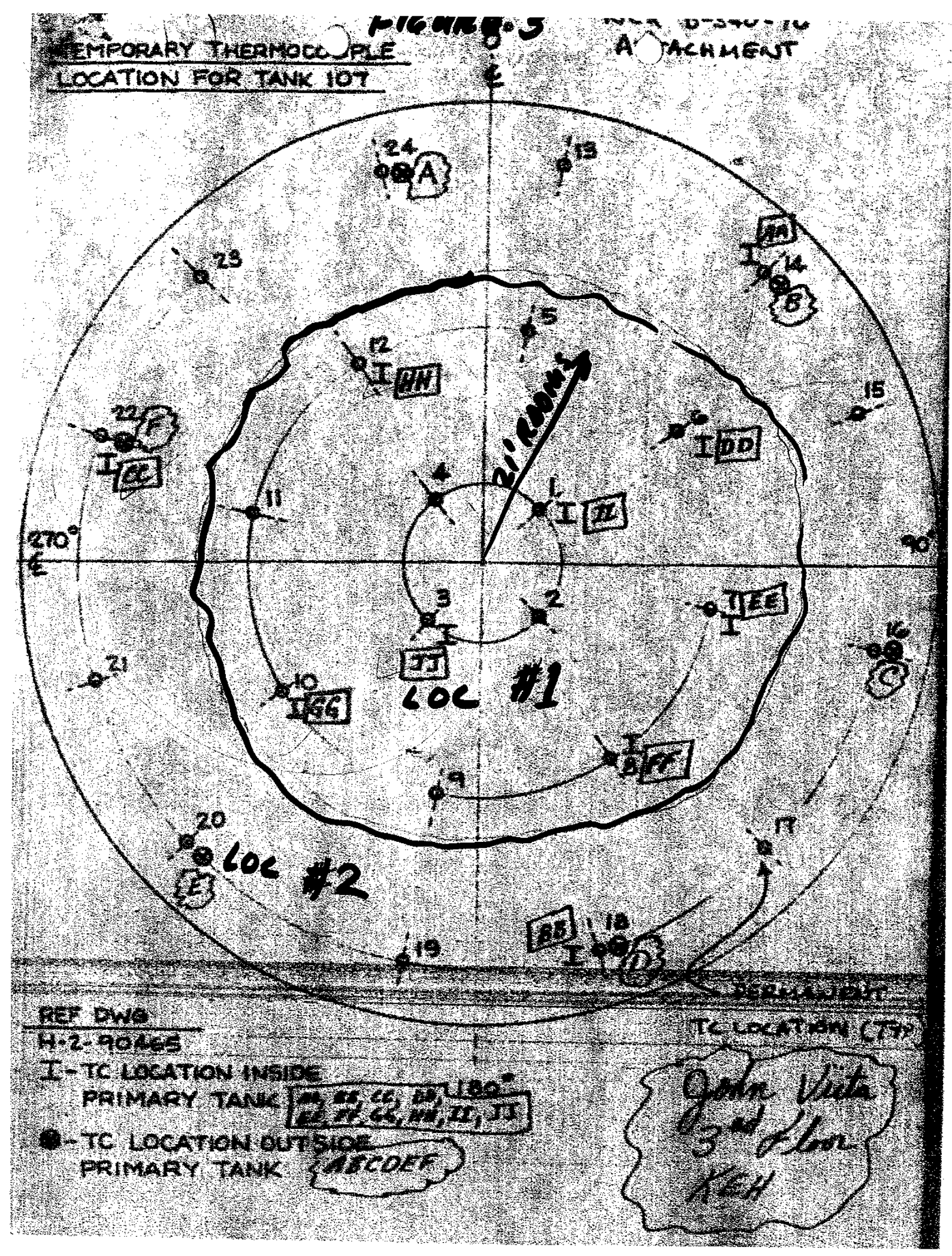


RPP-RPT-55983, Rev. 0

App. Figure B-11. Nonconformance Report B-340-81

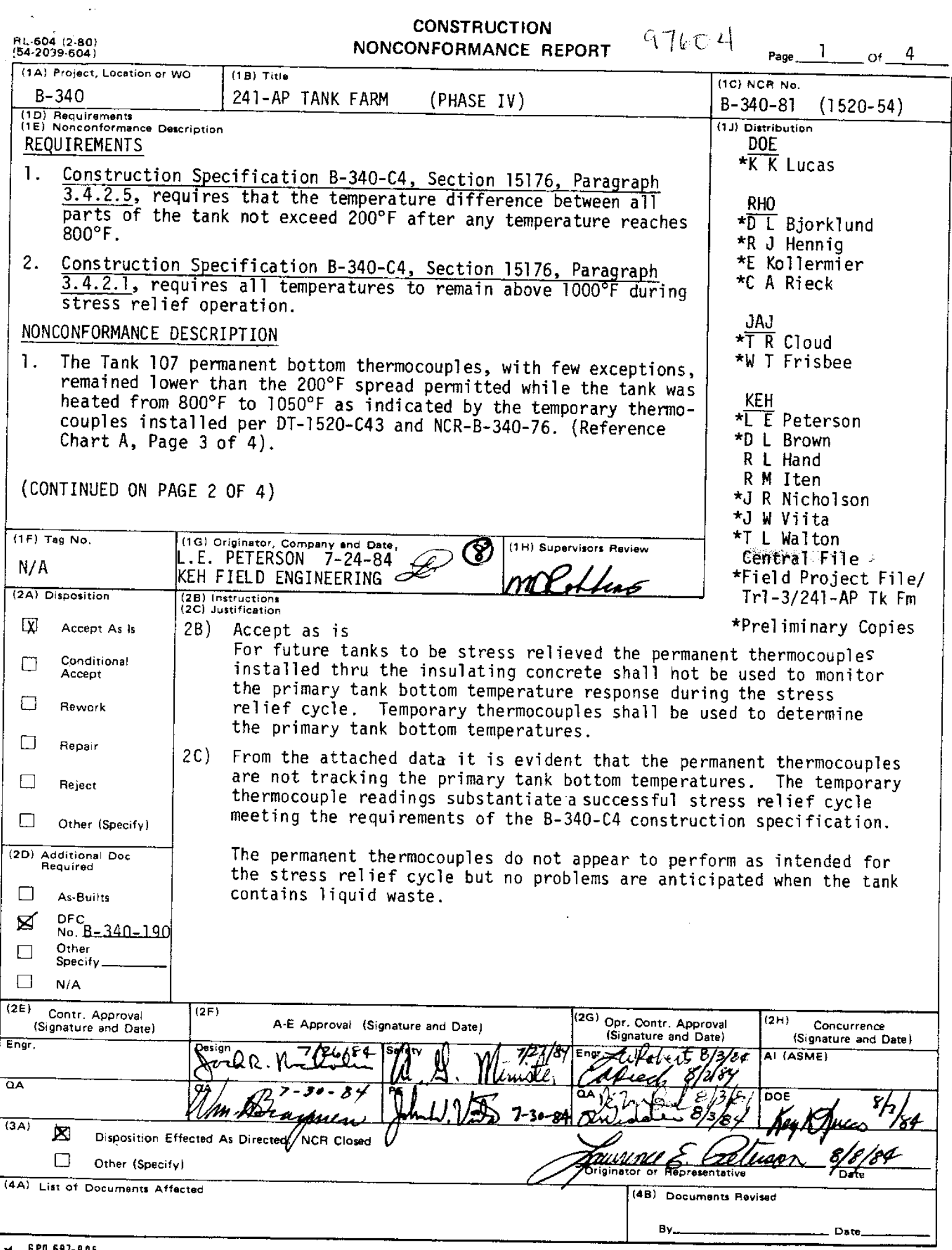

48 6PO 697-905 
RPP-RPT-55983, Rev. 0

NCR B-340-81

Page 2 of 4

NONCONFORMANCE DESCRIPTION (continued)

2. The Tank 107 permanent bottom thermocouples remained below $1000^{\circ} \mathrm{F}$ during the entire 3 hours that the temporary thermocouples remained near $1050^{\circ} \mathrm{F}$. (Reference Chart B, Page 3 of 4 )

NOTE: All temporary thermcouples installed per NCR B-340-76 on the interior bottom and lower portion of the exterior bottom knuckle indicated temperatures that conformed to the stress relief procedure.

Data Transmittal \#1520-A48.1 contains the entire Tank 107 Heat Treat Temperature Records. 
RPP-RPT-55983, Rev. 0

NCR B-340-81

Page 3 of 4

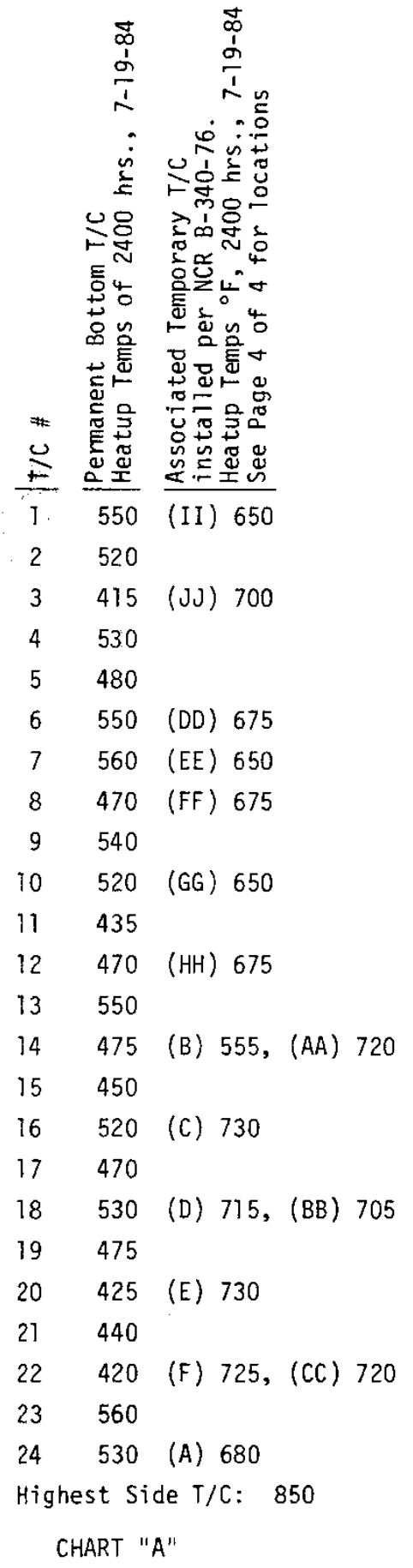

\begin{tabular}{|c|c|c|c|c|}
\hline $\begin{array}{l}* \\
\stackrel{*}{E}\end{array}$ & 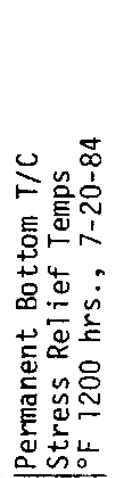 & 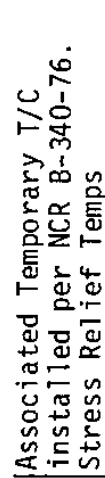 & 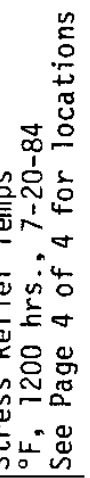 & \\
\hline 1 & 945 & (II) & 1030 & \\
\hline 2 & 950 & & & \\
\hline 3 & 895 & (JJ) & 1065 & \\
\hline 4 & 975 & & & \\
\hline 5 & 935 & & & \\
\hline 6 & 965 & (DD) & 1050 & \\
\hline 7 & 970 & (EE) & 1030 & \\
\hline 8 & 925 & $\langle F F\rangle$ & 1030 & \\
\hline 9 & 965 & & & \\
\hline 10 & 950 & (GG) & 1030 & \\
\hline 11 & 920 & & & \\
\hline 12 & 925 & $(\mathrm{HH})$ & 1055 & \\
\hline 13 & 990 & & & \\
\hline 14 & 940 & (B) 1 & 1050 & (AA) 1090 \\
\hline 15 & 925 & & & \\
\hline 16 & 975 & (C) 1 & 1100 & \\
\hline 17 & 965 & & & \\
\hline 18 & 990 & (D) 1 & 1100 & (BB) 1090 \\
\hline 19 & 955 & & & \\
\hline 20 & 920 & (E) 1 & 1100 & \\
\hline 21 & 945 & & & \\
\hline 22 & 985 & (F) 1 & 1075 & (CC) 1090 \\
\hline 23 & 995 & & & \\
\hline 24 & 960 & (A) 1 & 1050 & \\
\hline \multicolumn{3}{|c|}{ Average Side/Top } & Temp: & 1103 \\
\hline
\end{tabular}


RPP-RPT-55983, Rev. 0

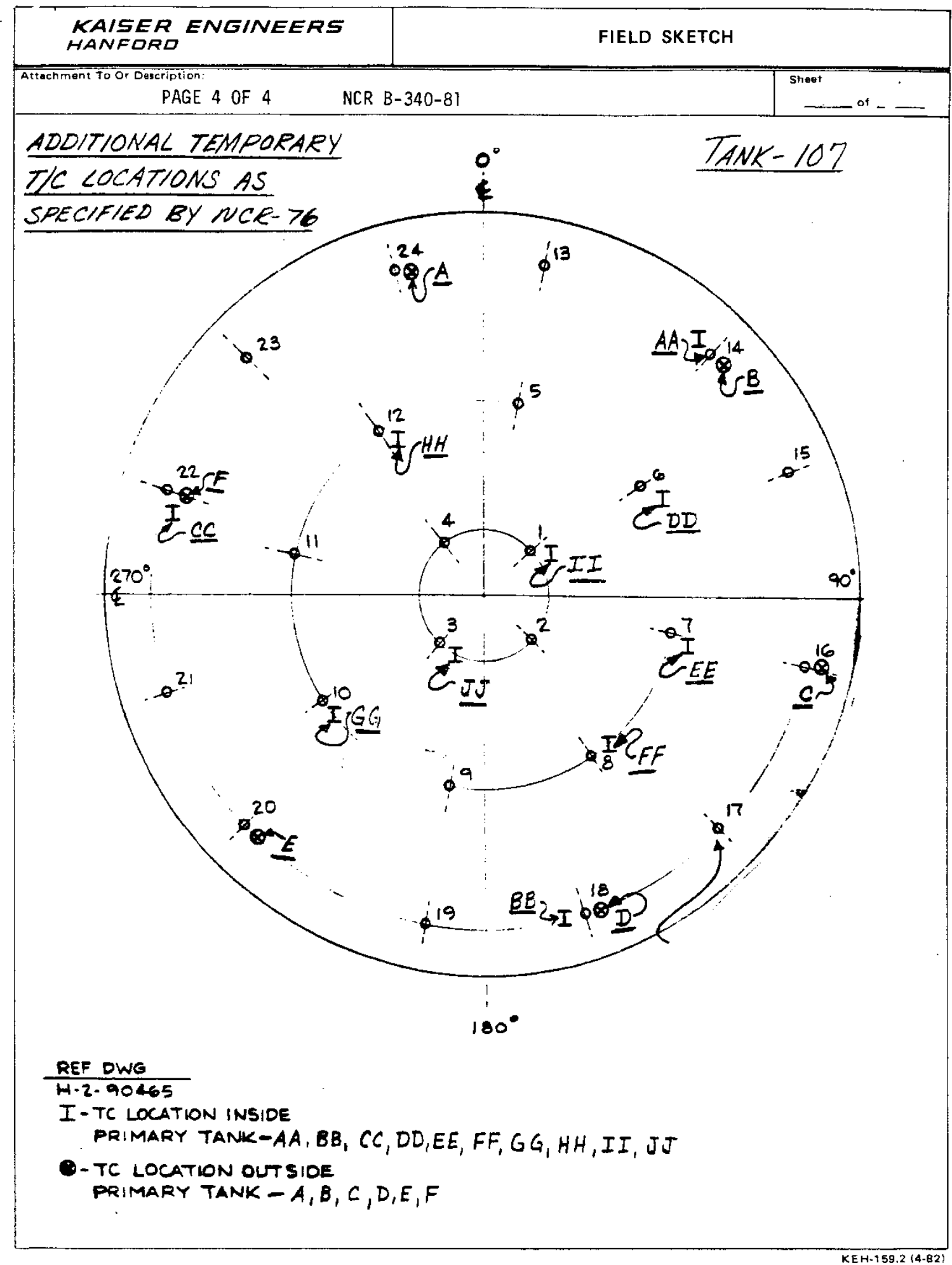


RPP-RPT-55983, Rev. 0

\section{App. Figure B-12. Nonconformance Report B-340-88}

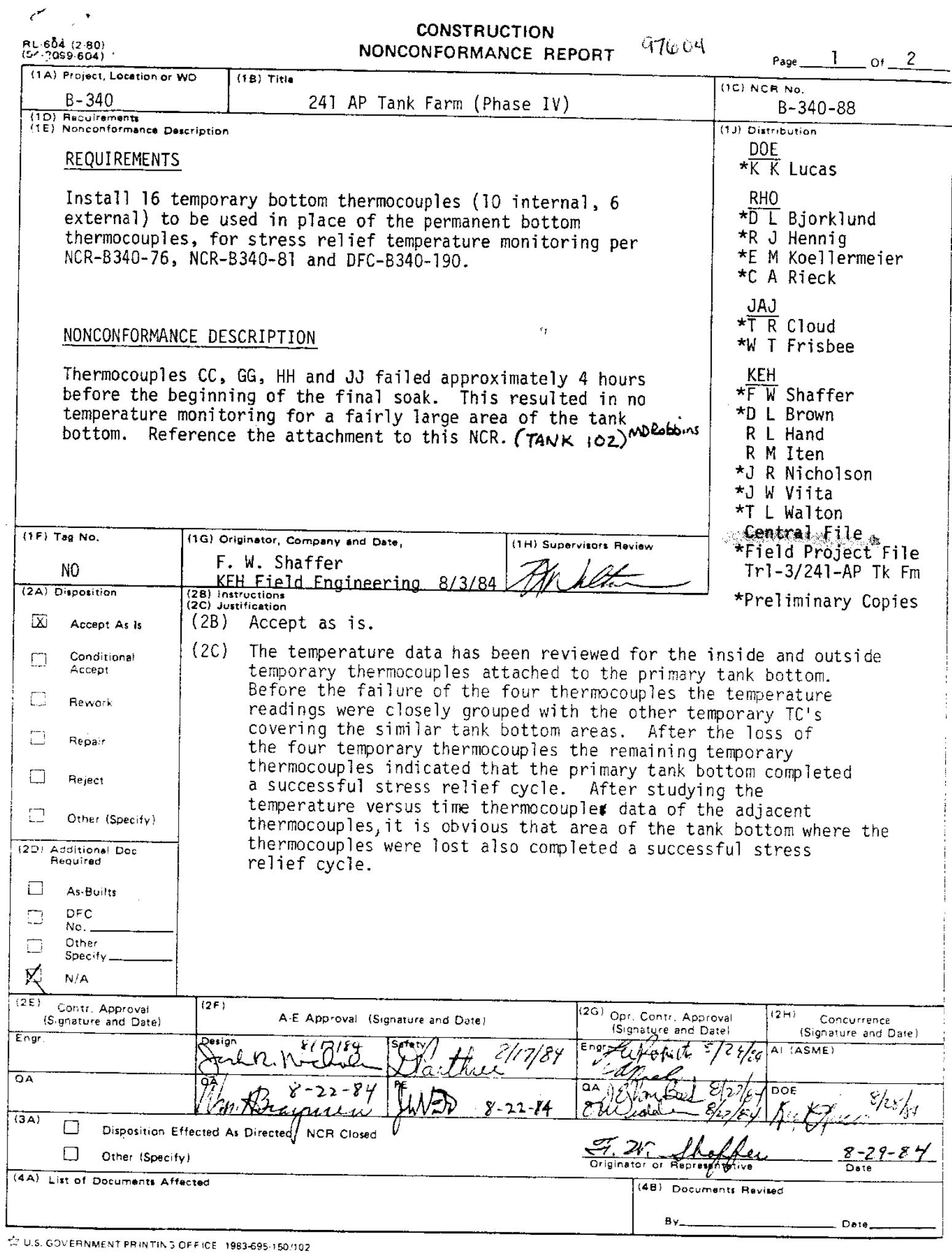


RPP-RPT-55983, Rev. 0

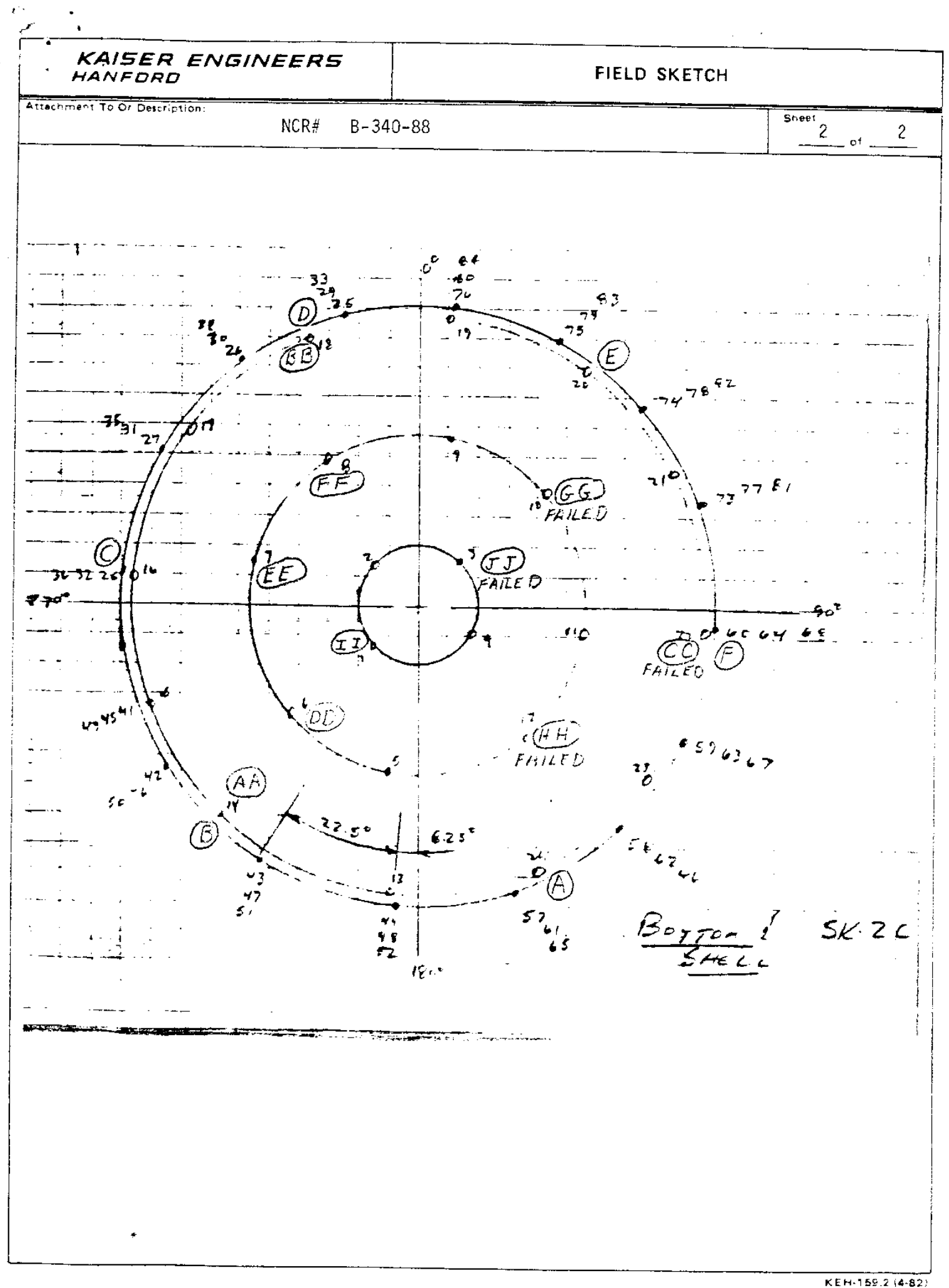


RPP-RPT-55983, Rev. 0

App. Figure B-13. Nonconformance Report B-340-95

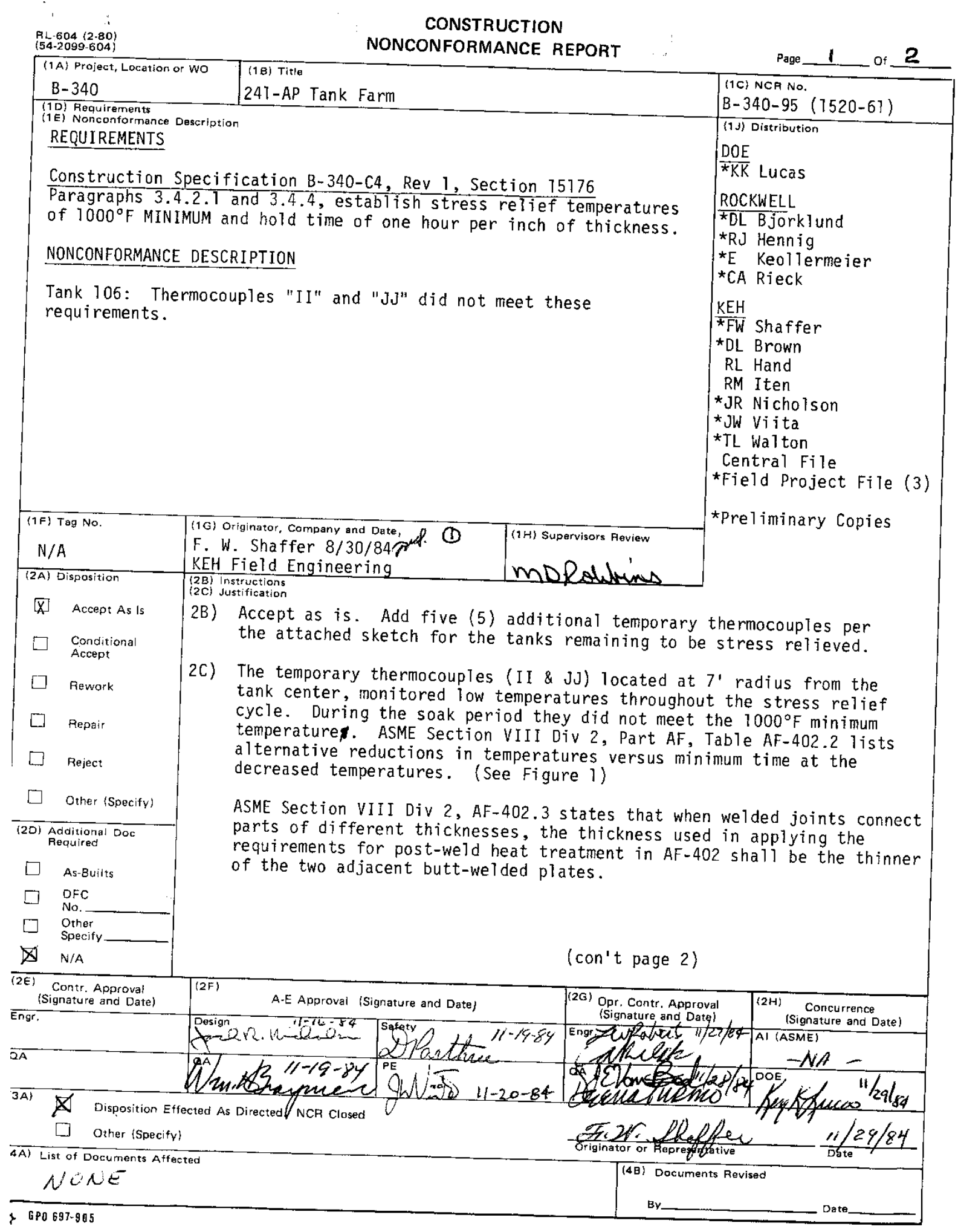


RPP-RPT-55983, Rev. 0

NCR B-340-95

Page 2

JUSTIFICATION (con't)

The temporary thermosouples (II \& JJ) monitored $1 / 2 "$ plate primary tank bottom temperatures, and this thickness shall govern the stress relieving requirements for welds in this area.

A review of the lowest reading thermocouple (II) data indicates the following:

$\begin{array}{ll}\frac{\text { TIME }}{4 \text { hours }} & \frac{\text { TEMP }}{900^{\circ} \mathrm{F}+} \\ 3 \text { hours } & 950^{\circ} \mathrm{F}+\end{array}$

Table AF 402.2 allows a $150^{\circ} \mathrm{F}$ decrease in temperature from the $1100^{\circ} \mathrm{F}$ specification requirement which yields $950^{\circ} \mathrm{F}$ minimum temperature and requires a minimum holding time of five (5) hours per inch of metal thickness. For the area that the temporary thermocouples monitored $\left(1 / 2^{\prime \prime}\right.$ thick plate), this translates to $21 / 2$ hours at $950^{\circ} \mathrm{F}\left(150^{\circ} \mathrm{F}\right.$ decrease below $\left.1100^{\circ} \mathrm{F}\right)$, which satisfies the minimum requirements for stress relieving that area of the tank.

It is obvious from studying the stress relief cycles for previous tanks that the primary tank bottom center is the area recording the lowest temperatures and the area that determines the completion of the stress relief cycle. Additional thermocouple instrumentation is required in this area to offer redundancy in case of further thermocouple failure or erratic thermocouple data and adequately monitor the temperature distribution in that area. 
RPP-RPT-55983, Rev. 0

NCR B-340-95

TABLE AF-402.2

ALTERNATIVE REQUIREMENTS FOR POSTWELD

HEAT TREATMENT OF PRESSURE PARTS

AND ATTACHMENTS

Exemptions Provided in the Note Are Not

Applicable to Vessels in Lethal Service. See AG-301.1(c)

\begin{tabular}{cc}
$\begin{array}{c}\text { Decrease in } \\
\text { Temperature Below } \\
\text { Normal Holding } \\
\text { Temperature, }\end{array}$ & $\begin{array}{c}\text { Minimum } \\
\text { Time at Decreased } \\
\text { Temperature, } \\
\mathrm{hr} / \text { in. of thickness }\end{array}$ \\
\hline 50 & 2 \\
100 & 3 \\
150 & 5 \\
200 & 10 \\
\hline
\end{tabular}

NOTE:

(1) Postweld heat treatment at lower temperatures for longer periods of time, in accordance with this Table, shall be used only where permitted in Table AF-402.2.

FIGURE 1 
RPP-RPT-55983, Rev. 0

$$
\begin{aligned}
& \text { KCR - B-340-95 } \\
& \text { ATTACHMENT W }
\end{aligned}
$$

\section{PRIMARY TANK BOTTOM (INUSIDE SURFACE)}

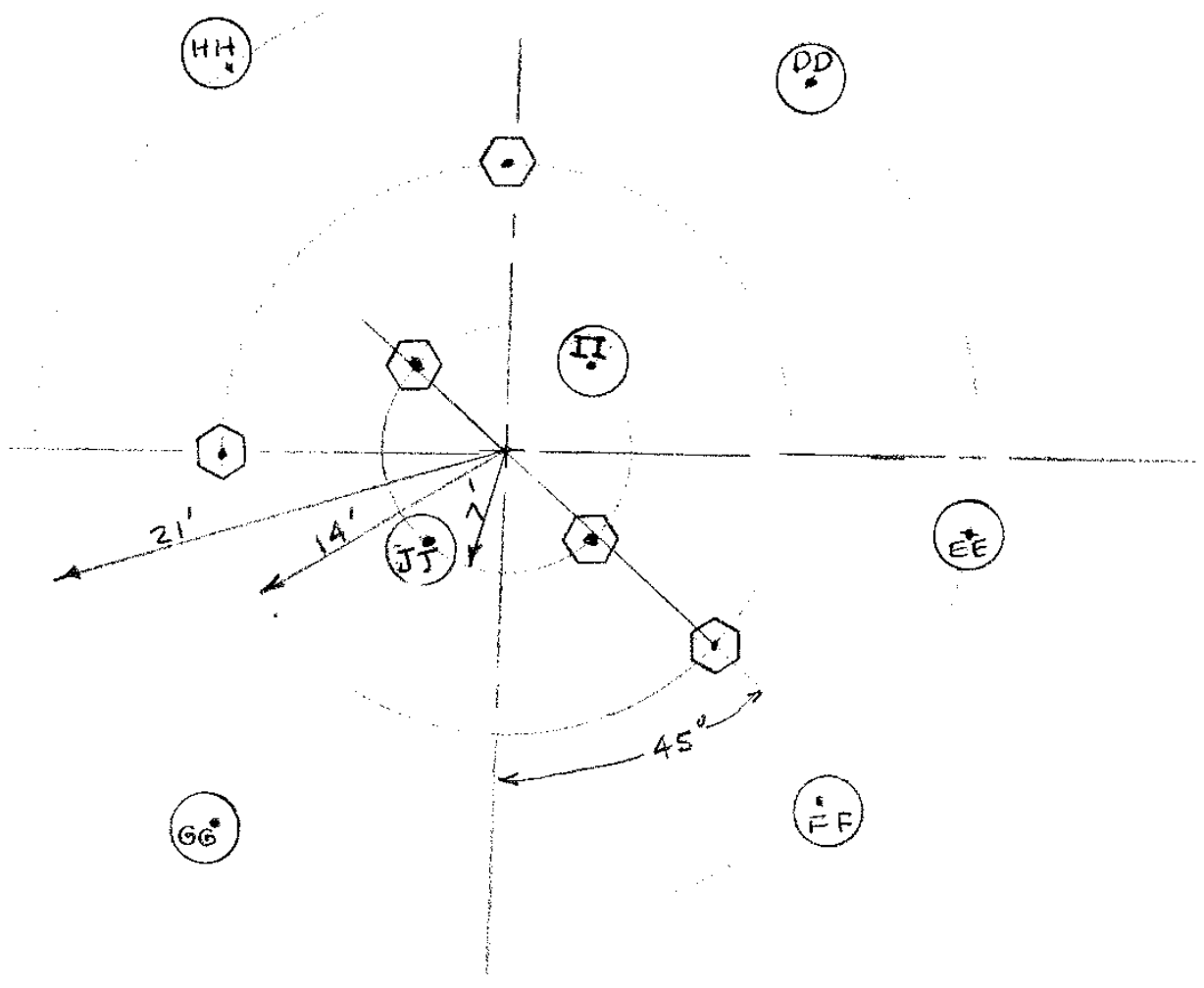

\footnotetext{
(HH) - ExISTING TEMPorary THEMmOCOUPLES (DD, EE, FE, GG, HH,

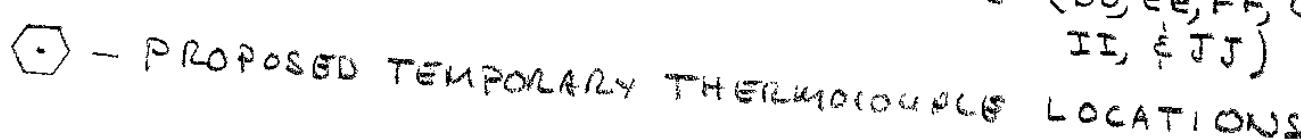


RPP-RPT-55983, Rev. 0

App. Figure B-14. Nonconformance Report B-340-96

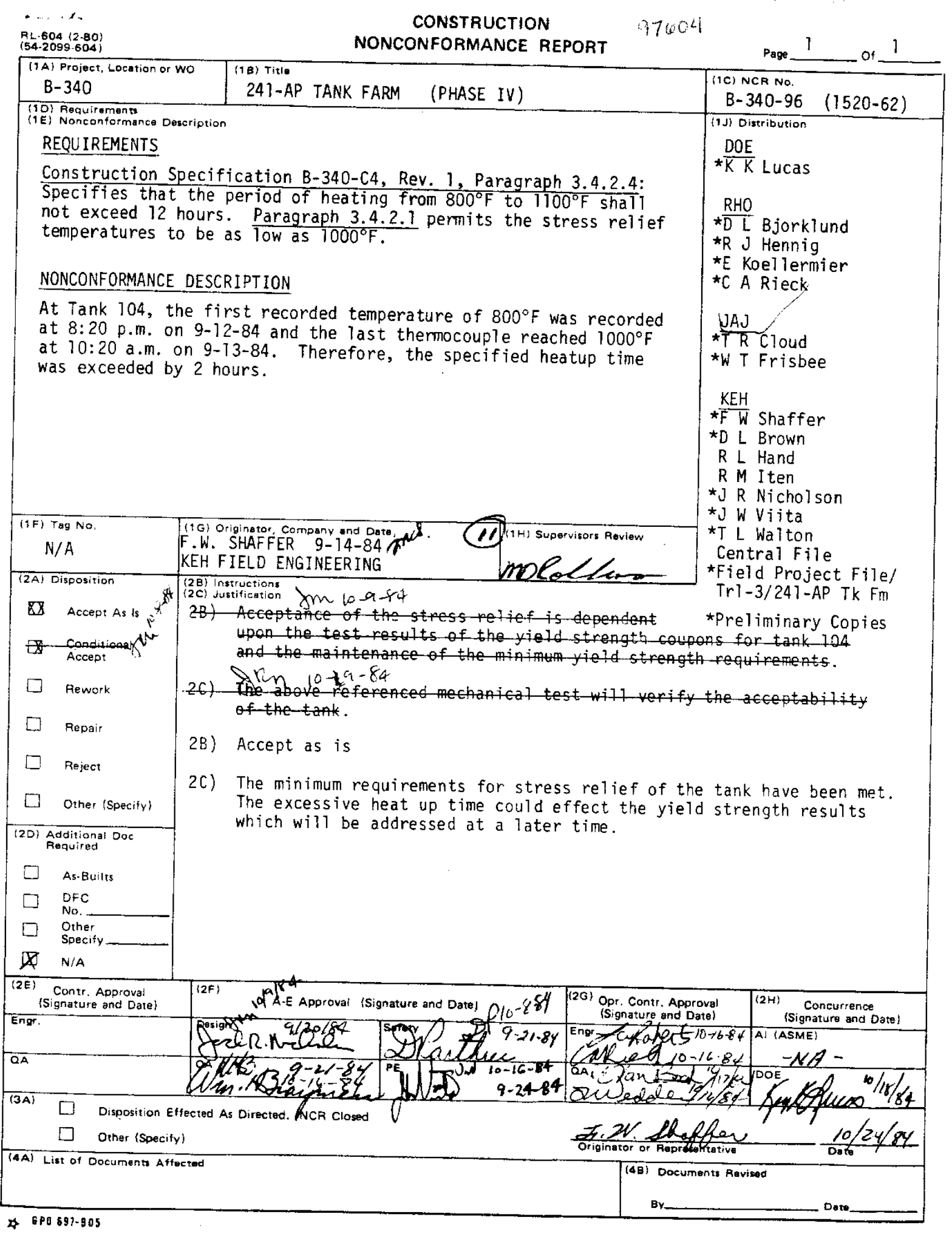


App. Figure B-15. Nonconformance Report B-340-115

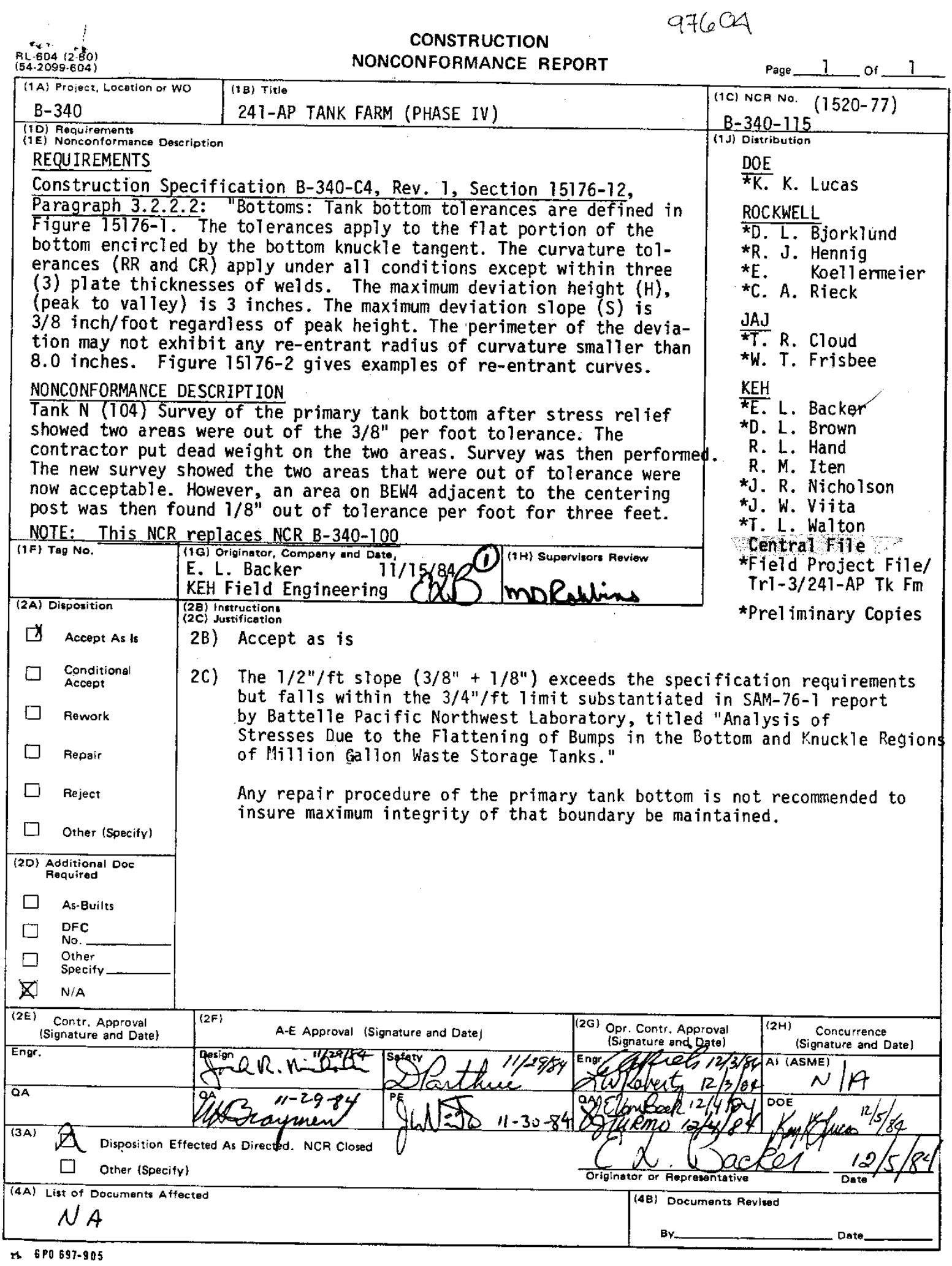


RPP-RPT-55983, Rev. 0

App. Figure B-16. Nonconformance Report B-340-56

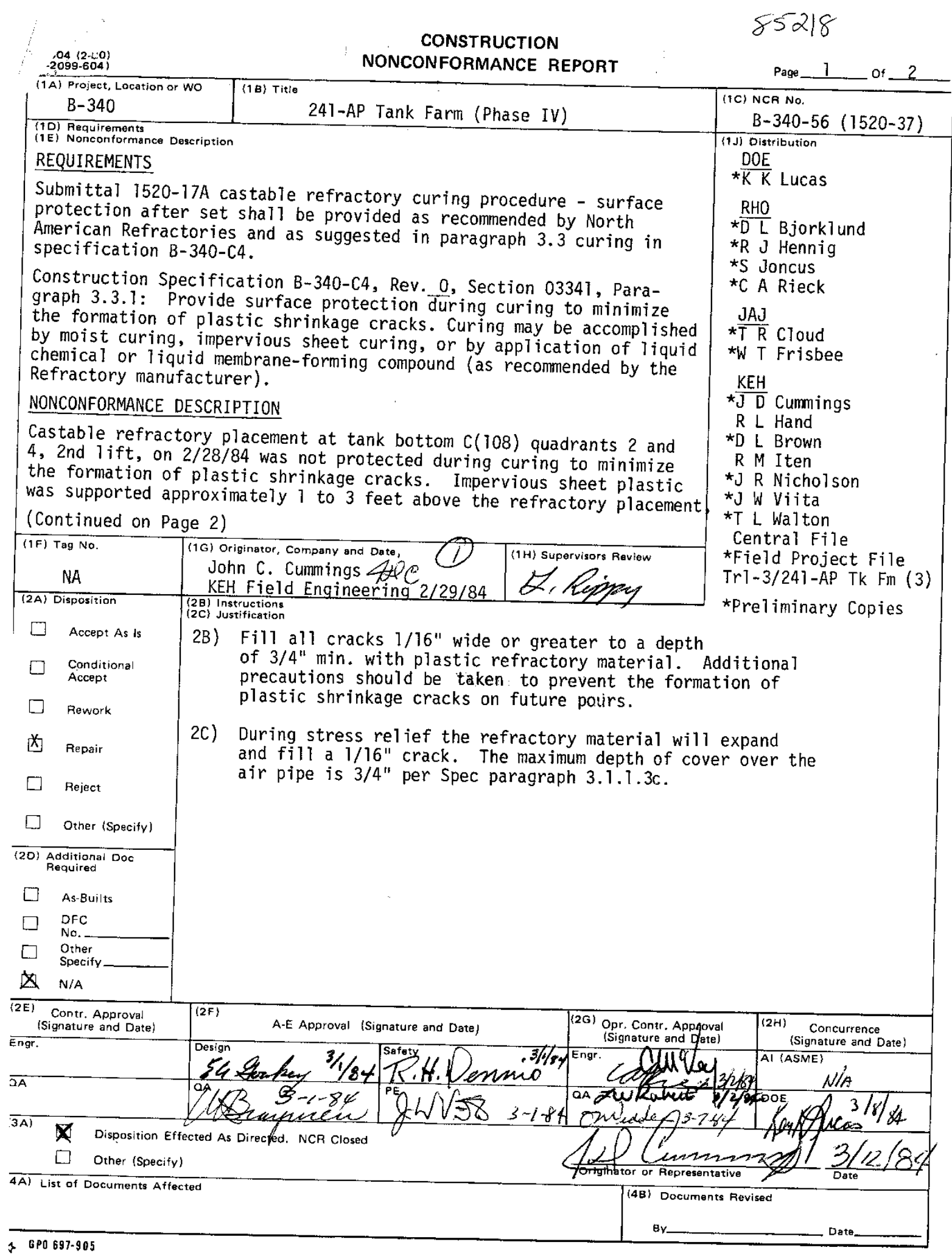


RPP-RPT-55983, Rev. 0

Page 2 of 2

NCR \#B-340-56 (1520-37)

however, the cover was open on a majority of the perimeter allowing the wind to blow across the refractory placement. Heaters were situated to blow between cover and refractory placement. Excessive plastic shrinkage cracks developed. See attached photos.

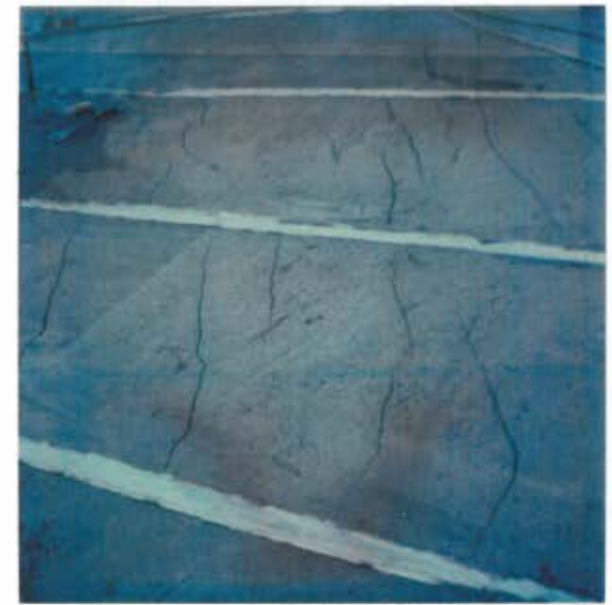

TANK 108 , CASTABLE REFRACTORY 2nd Lift, Quacleants, $\neq 2$ \& $\$ 4$

$$
7: 30 \mathrm{Am} \quad 2.29 .84
$$
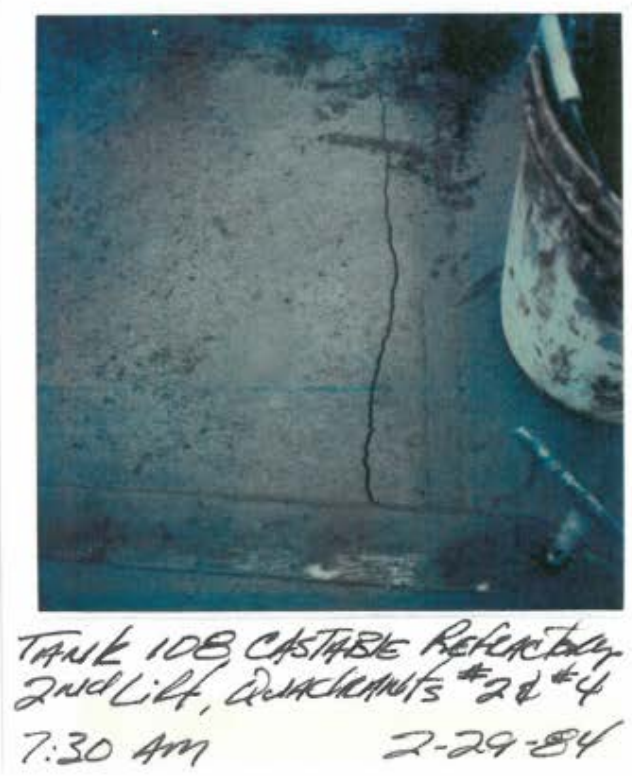

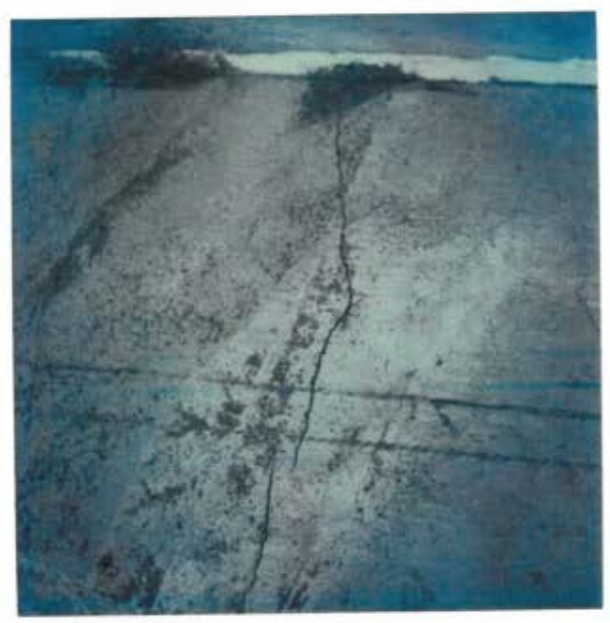

TANK 108, CASTAblE

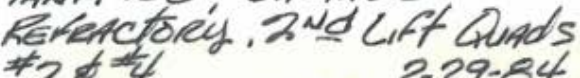
$2-29-84$

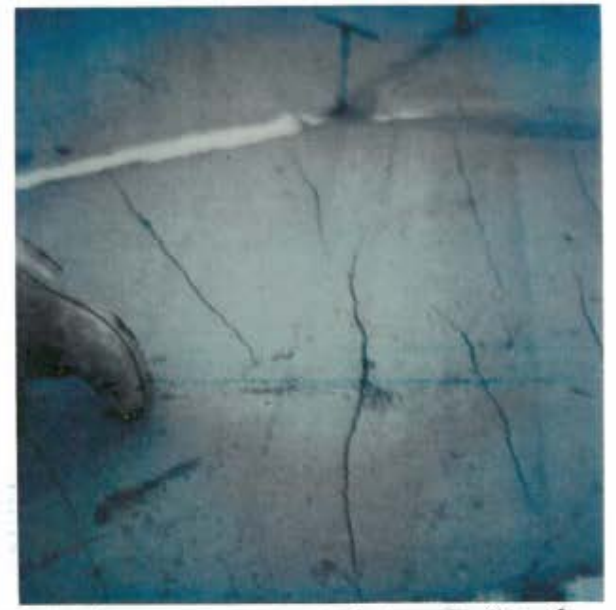

Thut 108, CAstrable ferefotory 2 nd Lift, QuAdeAnts 2 \& *4 $7.30 \mathrm{Am} \quad 2.29 .84$ 
RPP-RPT-55983, Rev. 0

\section{App. Figure B-17. Nonconformance Report B-340-85}

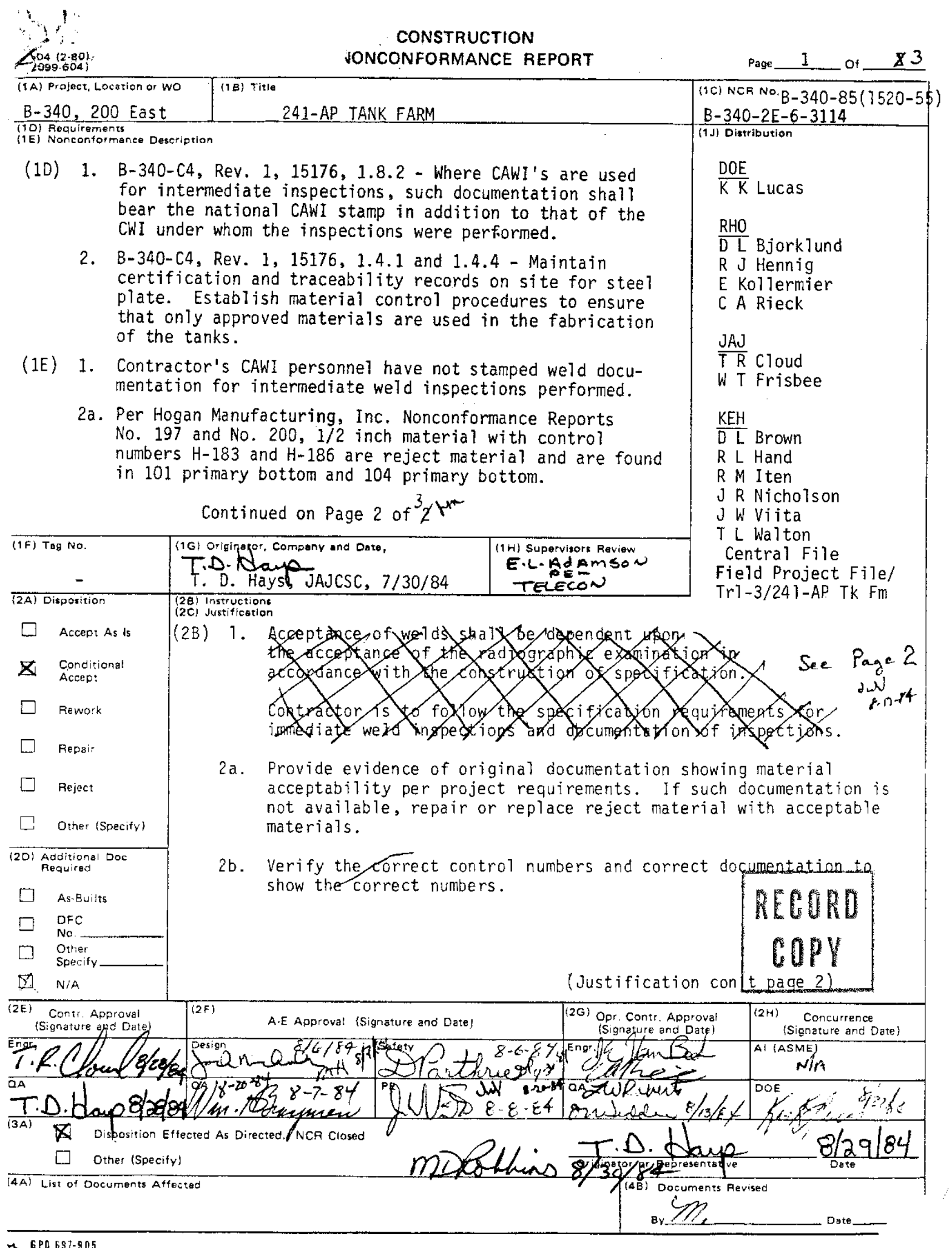


RPP-RPT-55983, Rev. 0

NCR No. B-340-2E-6-3114

Page 2 of 3

(1E) NONCONFORMANCE DESCRIPTION (cont.)

2b. Reference Hogan Manufacturing, Inc. Nonconformance Report No. 345. Based on control number verification, the following piece marks have incorrect control numbers indicated on material: 102-BO-11-1G (102 secondary bottom), 201-B01-2B (102 primary bottom), 302-M4-12E (108 primary she11), 503-M1-23A (104 secondary shell), and 503-M120G (104 secondary she11).

(2C) JUSTIFICATION

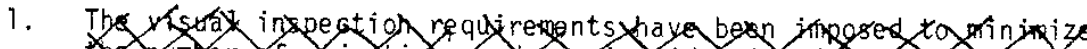

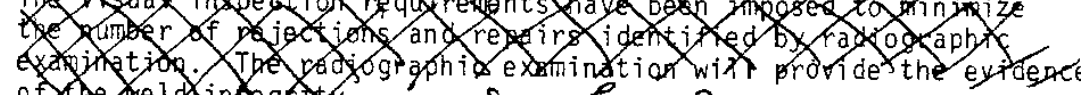

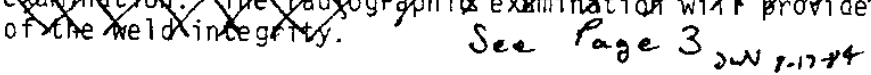

2a. Material must meet specification requirements.

2b. Proper documentation is necessary to provide traceability.

2B) REVISED ITEM 1 - INSTRUCTIONS

1. Acceptance of welds shall be dependent upon the acceptance of the radiographic examination in accordance with the construction specification.

On dome seam welds, contractor is to provide backup documentation (inspection reports or inspection logs for example) on intermediate weid inspections. If documentation cannot be provided, spot radiography shall be performed. Acceptance criteria shall be in accordance with Section VIII, Division 2, ASME Code. Not less than $2 \%$ of seam welds shall be examined. The welds to be examined shall be selected to ensure that each individual welder doing the production welding is included. The size of the spot shall be equivalent to the minimum film size allowed in accordance with the $C 4$ specification.

When a spot, radiographed as required, has been examined and the radiograph discloses welding which does not comply with the minimum quality requirements of Section VIII, Div. 2, two additional spots shall be radiographically examined in the same weld unit at locations away from the original spot. The locations of these additional shall be determined by the Government Representative.

If either of the two additional spots examined shows welding which does not comply with the code requirements, the entire unit of weld represented shall be rejected or, at the Contractor's option, the entire unit of weld represented shall be completely radiographed and defective welding only need be corrected. 
RPP-RPT-55983, Rev. 0

NCR No. B-340-2E-6-3114

Page 3 of 3

(2B) REVISED ITEM 1 (continued)

Contractor is to follow the specification requirements for

intermediate weld inspections and documentation of inspections.

(2C) JUSTIFICATION

1. The visual inspection requirements have been imposed to minimize the number of rejections and repairs identified by radiographic of the weld integrity.

On dome seam welds, visual examination is the only examination method required by specification. Visual examination is required on all intermediate weld passes and if thexamination is required at this point and the weld joint completed welds are not examined examination (radiography) is requiredeted, a volumetric type of the weld joint (particularly the intermediate the integrity 
App. Figure B-18. Letter from Hogan Manufacturing to American Bridge - Plate Laminations

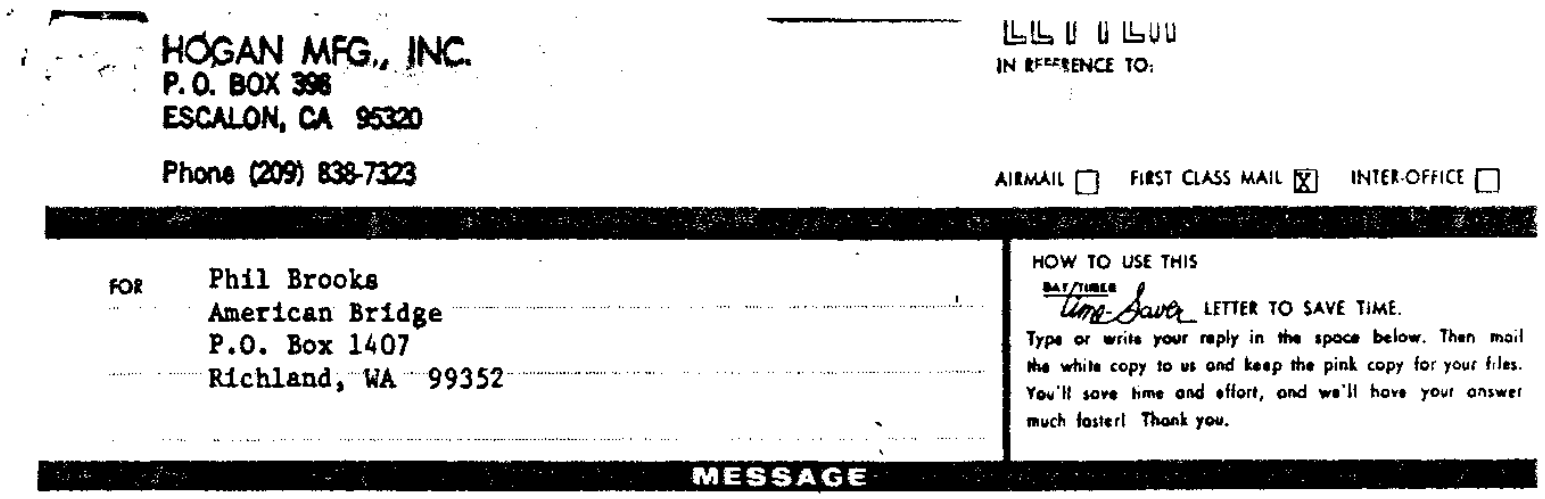

Ref : HMI Job \#83-544 AP 241 Tenk Farm, HMI Hold Tag 1974200 ,

July 30, 1984

Further review of the subject plates Indicated that what was percelved to be laminations were in fact acabs. These scaba were repalred by minor grinding by Hogan $\mathrm{Mfg}$. In Ileu of returning to vendor, Kalser Steel. Pits were acceptable in existing condftion.

This was done in an effort to reduce overall costs and shop requirements of subject material. Th1 determination was made after the NCR had been returned from the Profect Menager to the Q.C. Department.

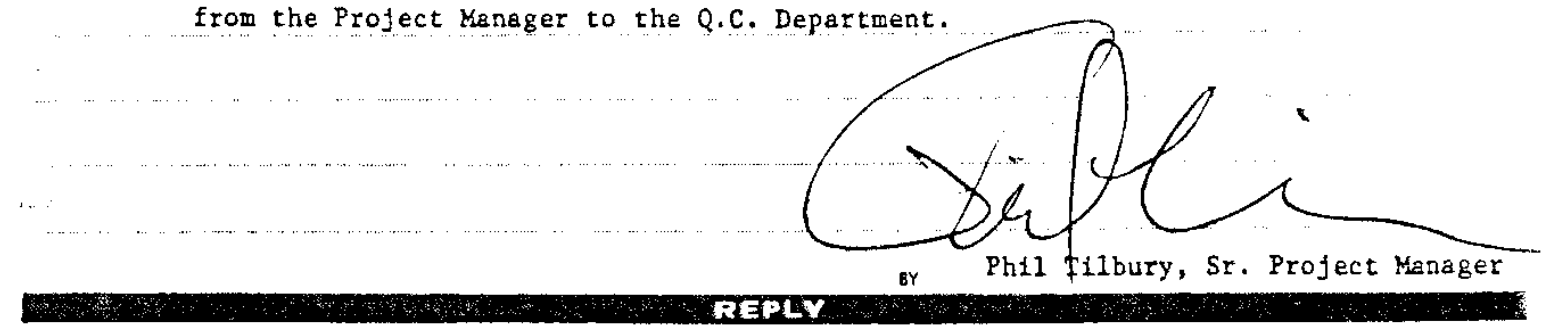

$$
\begin{aligned}
& \text { B. } 340.85 \\
& \text { ItEm } \# 22
\end{aligned}
$$


RPP-RPT-55983, Rev. 0

\section{App. Figure B-19. Nonconformance Report B-340-89}

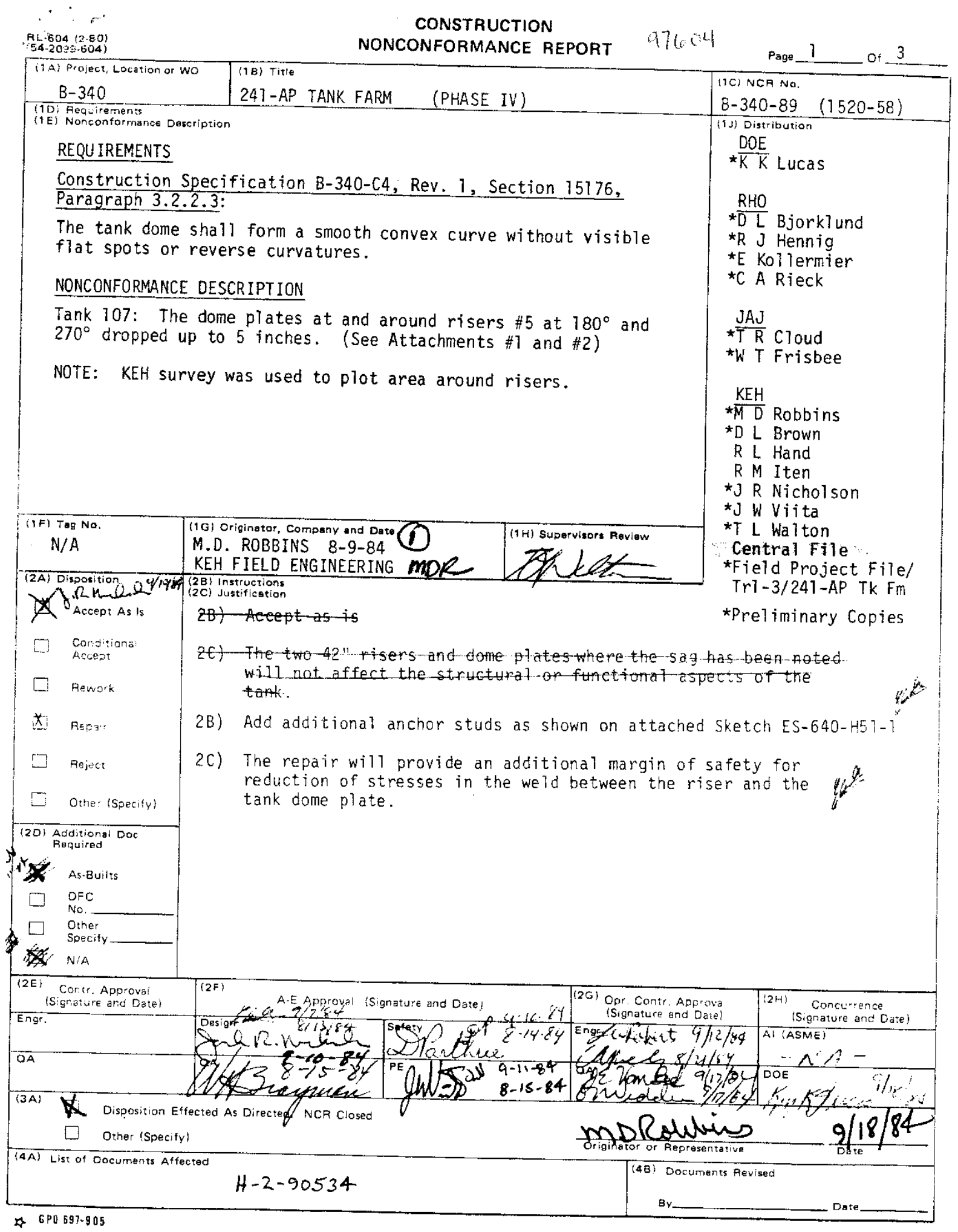


RPP-RPT-55983, Rev. 0

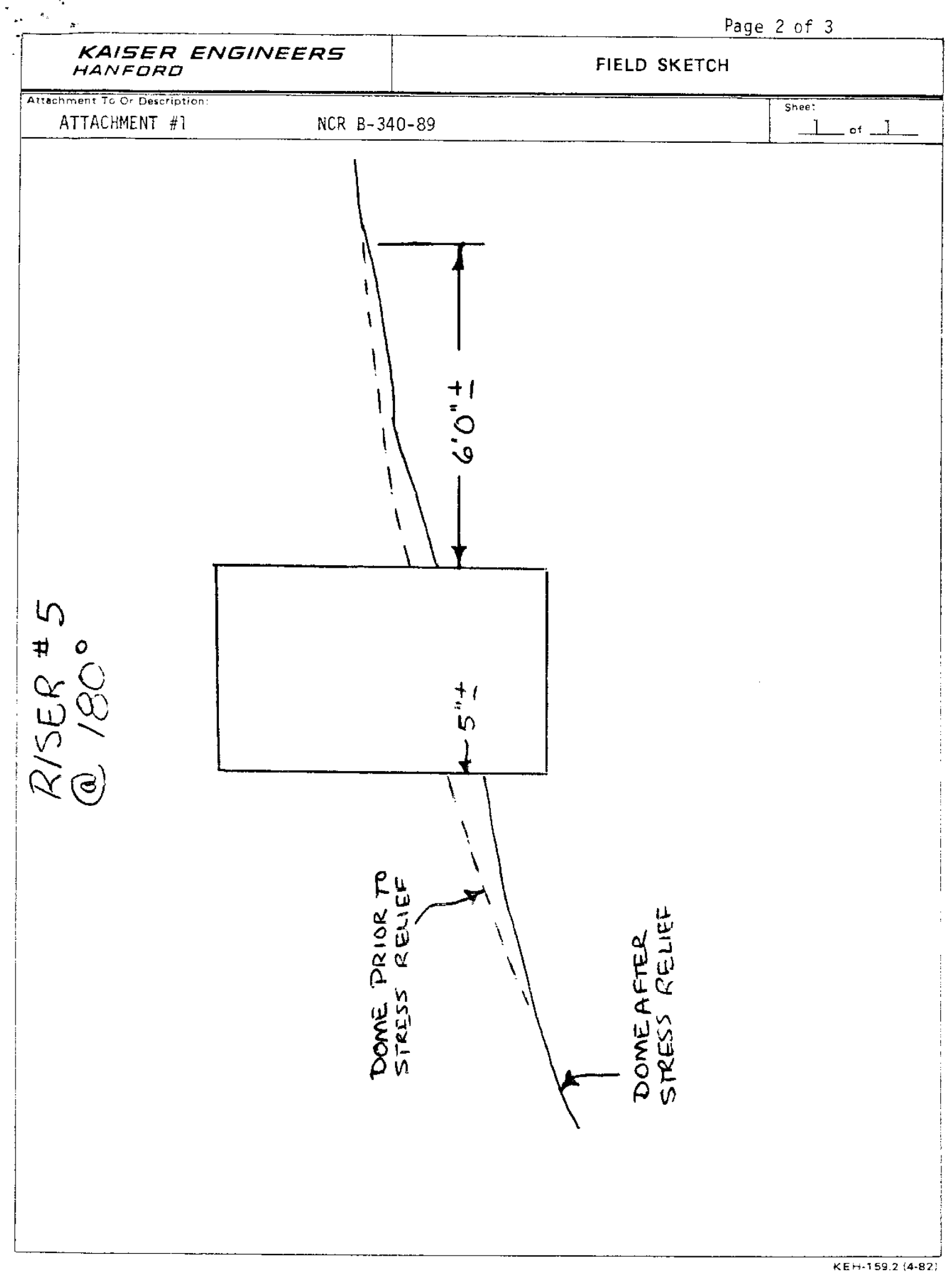


RPP-RPT-55983, Rev. 0

Page 3 of 3

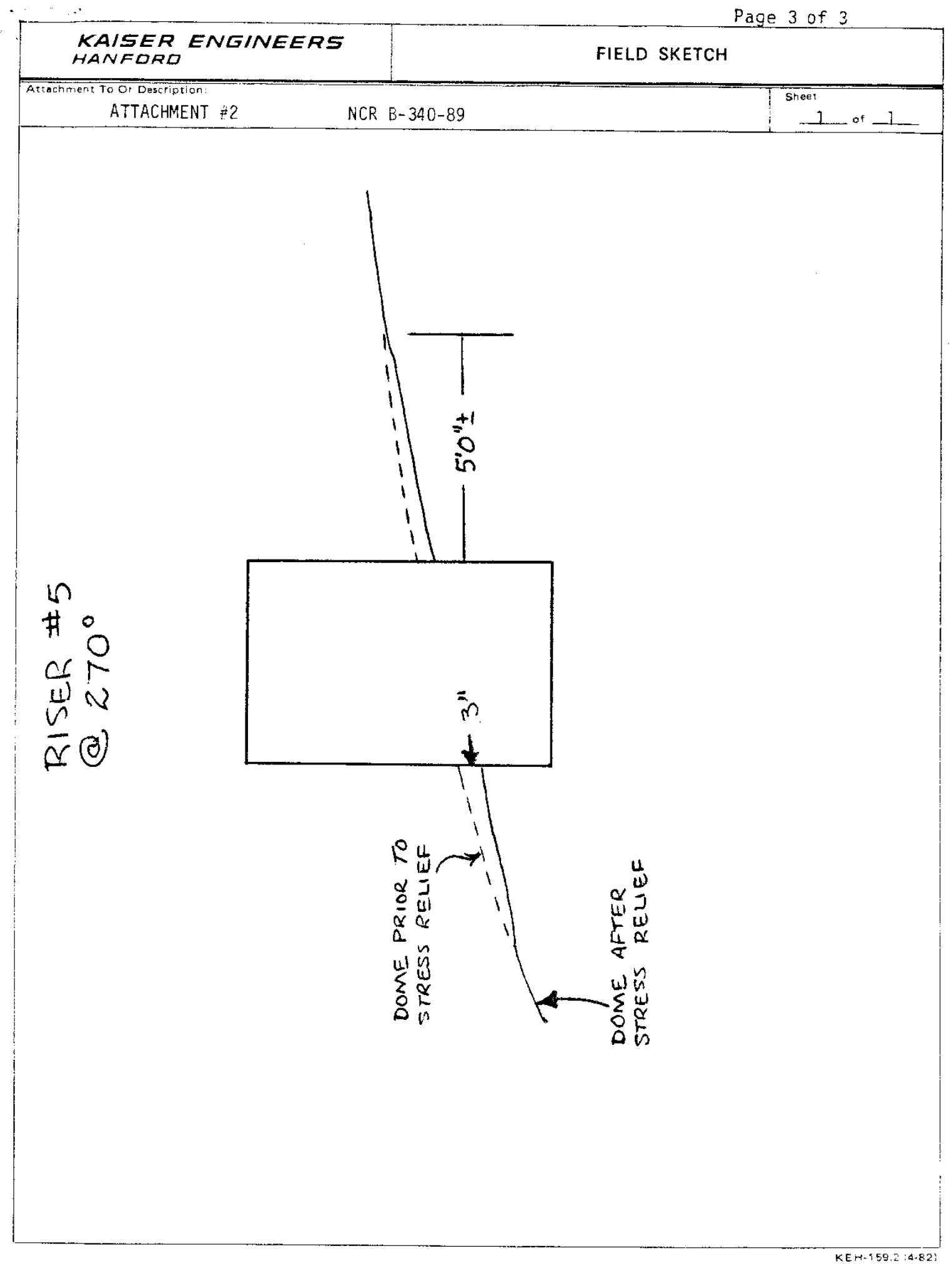


RPP-RPT-55983, Rev. 0

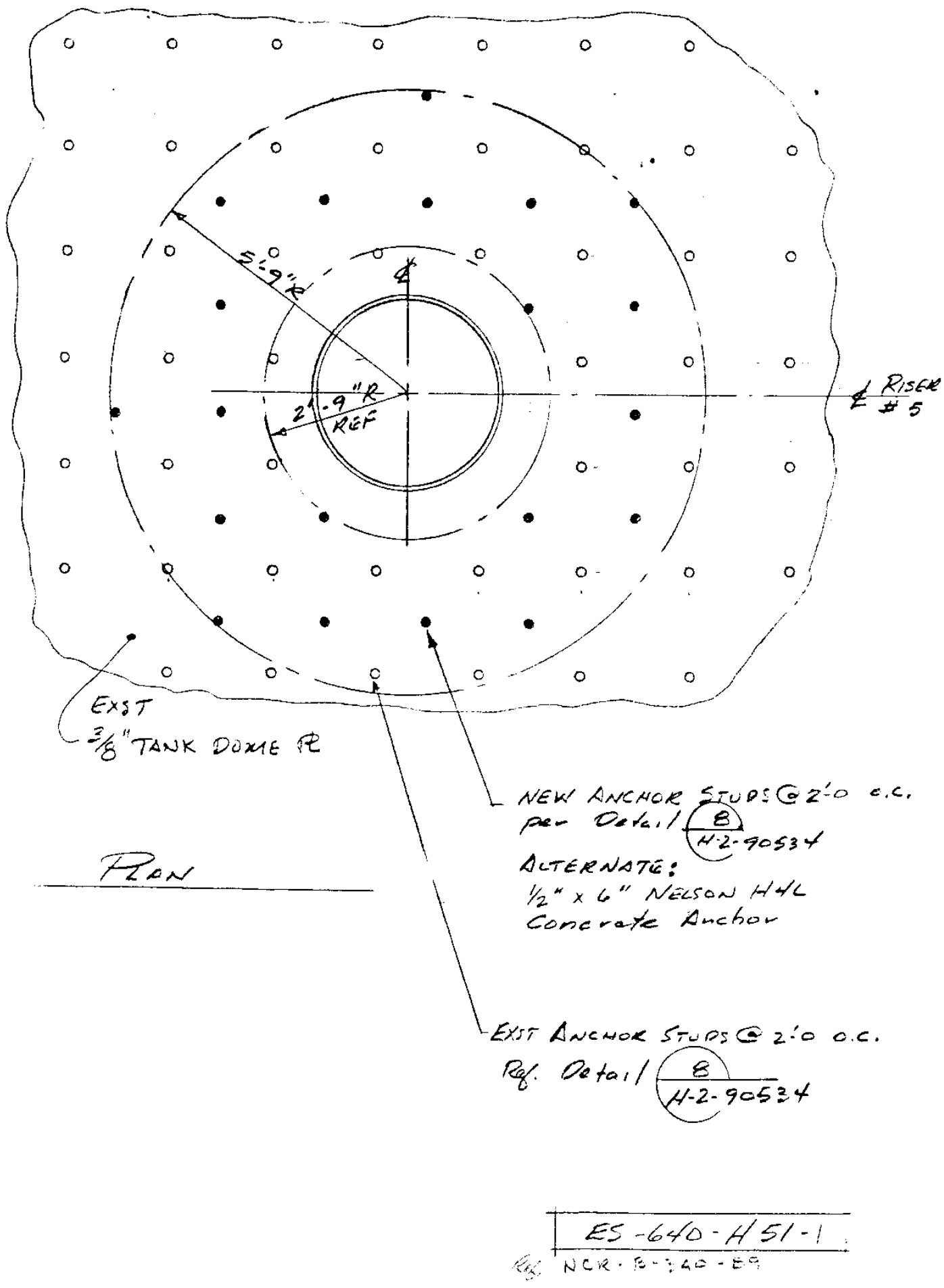


RPP-RPT-55983, Rev. 0

App. Figure B-20. Nonconformance Report B-340-98

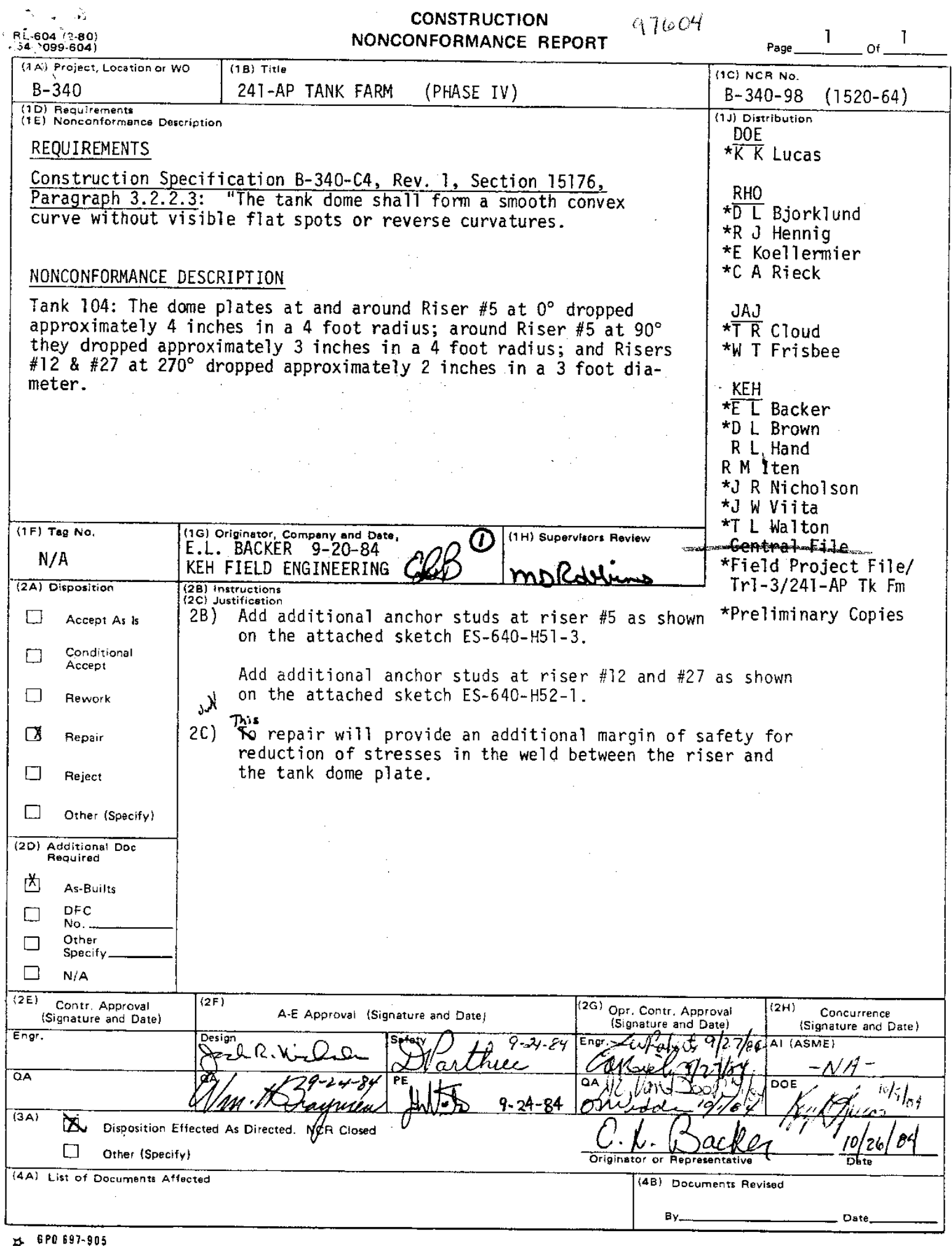


RPP-RPT-55983, Rev. 0

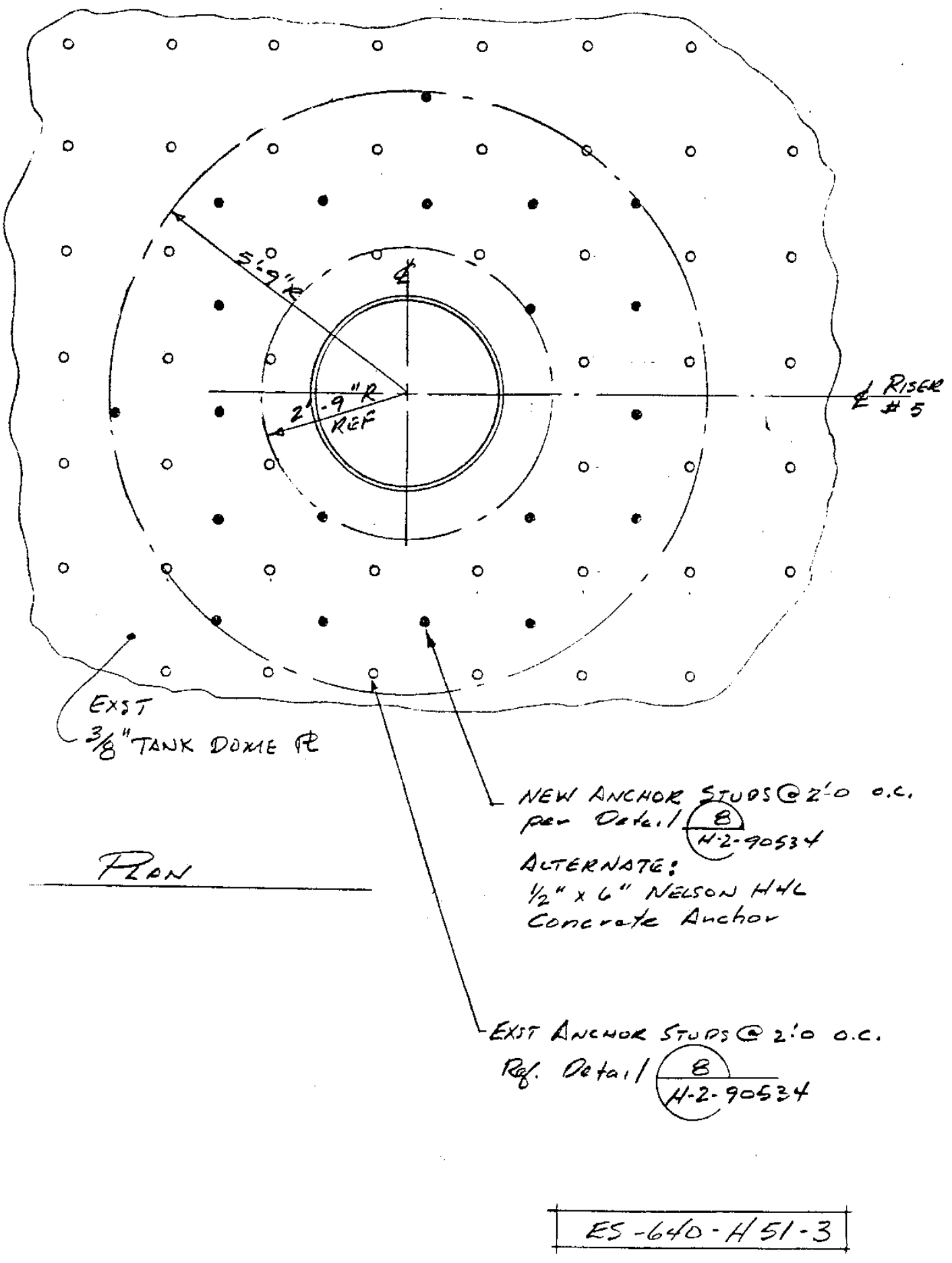


RPP-RPT-55983, Rev. 0

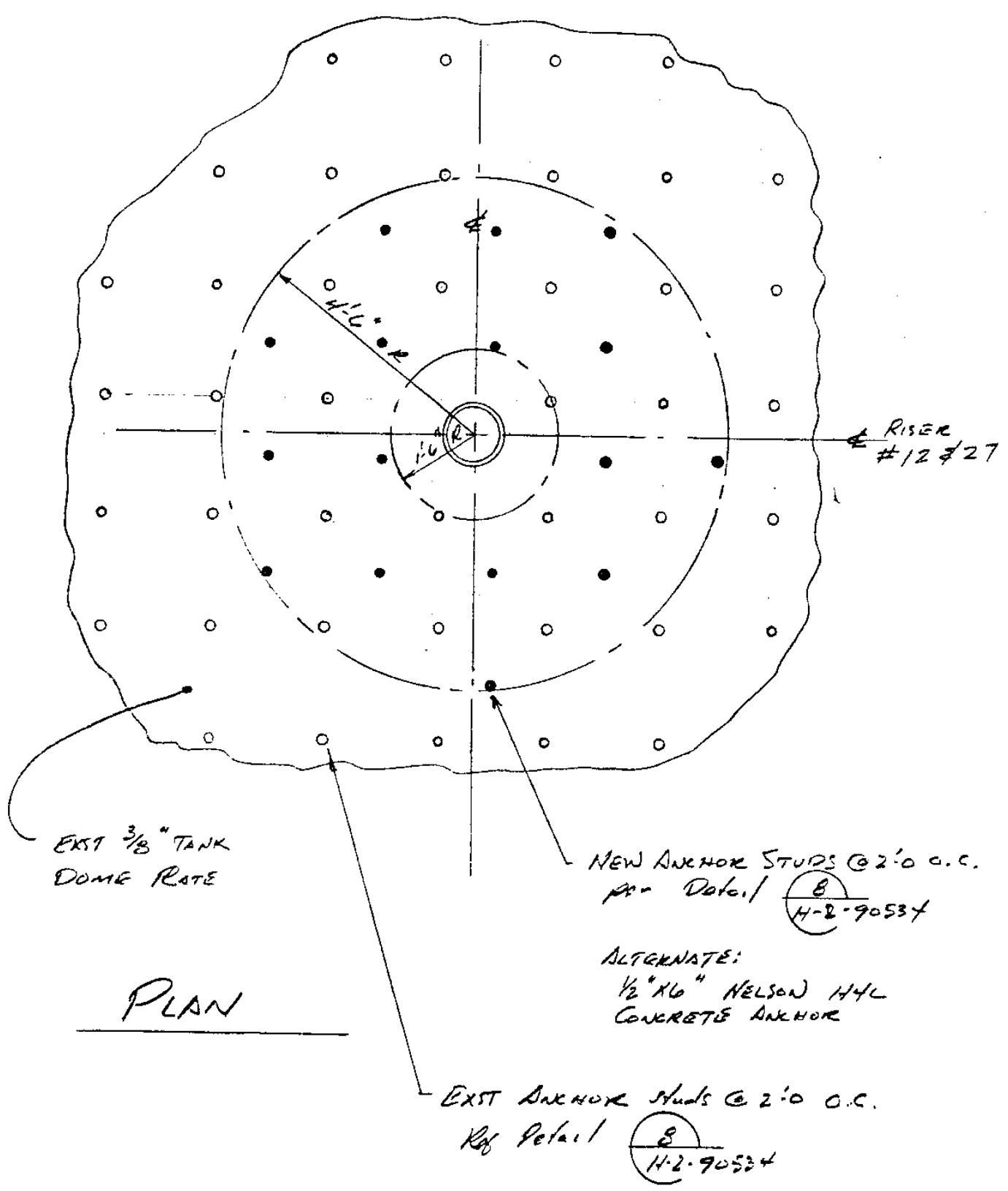

$$
\text { :ES-640-452-1 }
$$

B-46 
RPP-RPT-55983, Rev. 0

App. Figure B-21. Nonconformance Report B-340-102

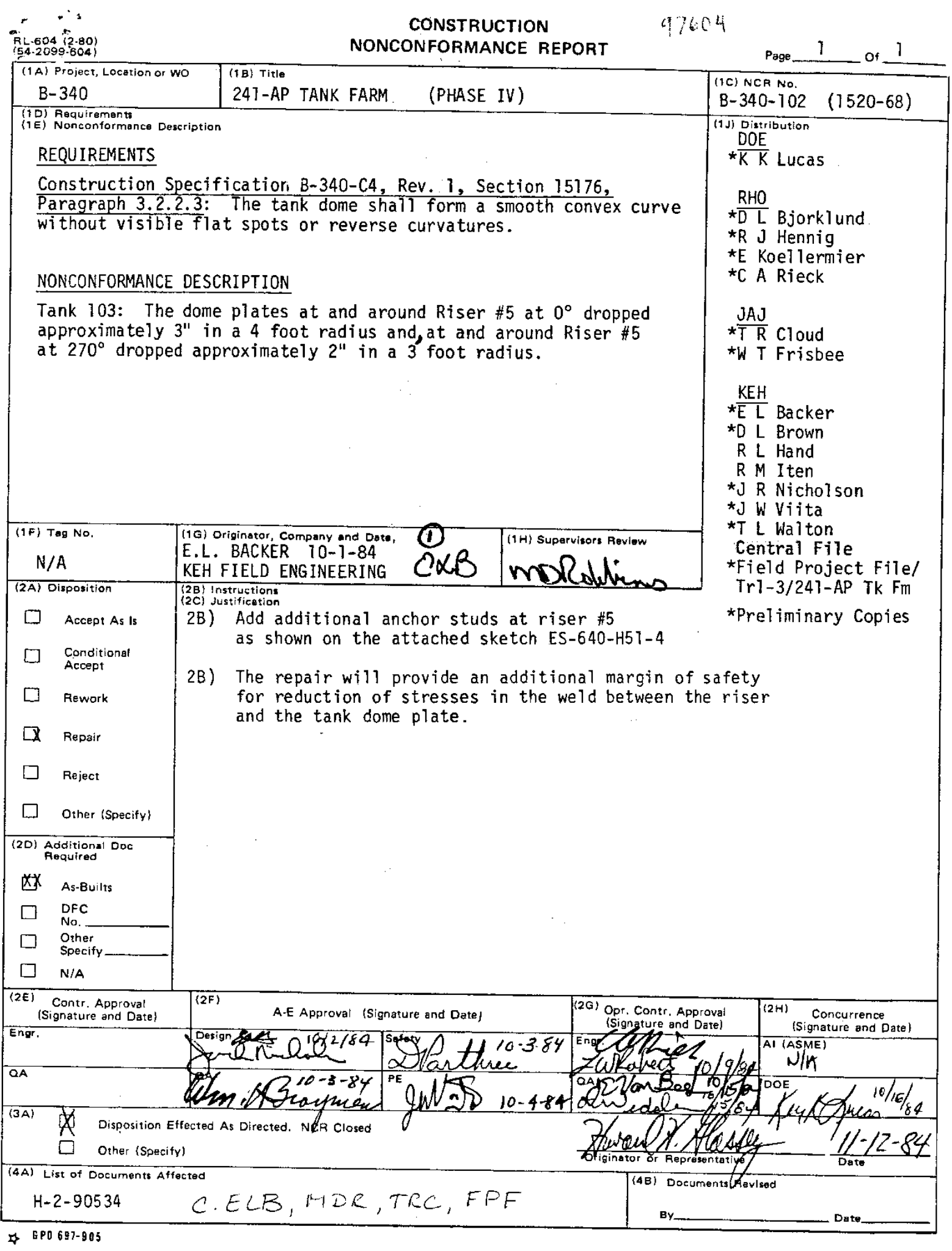


RPP-RPT-55983, Rev. 0
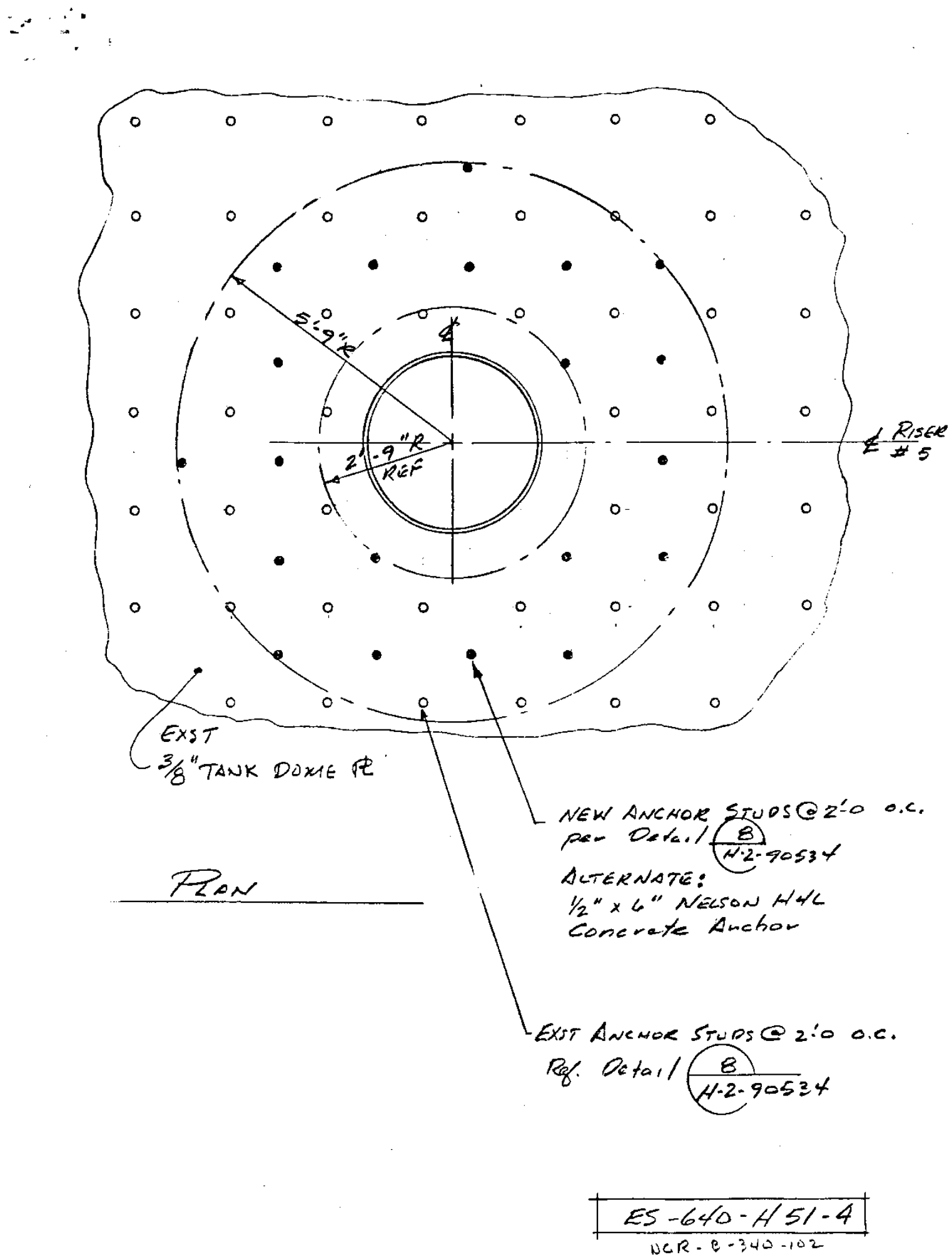
RPP-RPT-55983, Rev. 0

App. Figure B-22. Nonconformance Report B-340-105

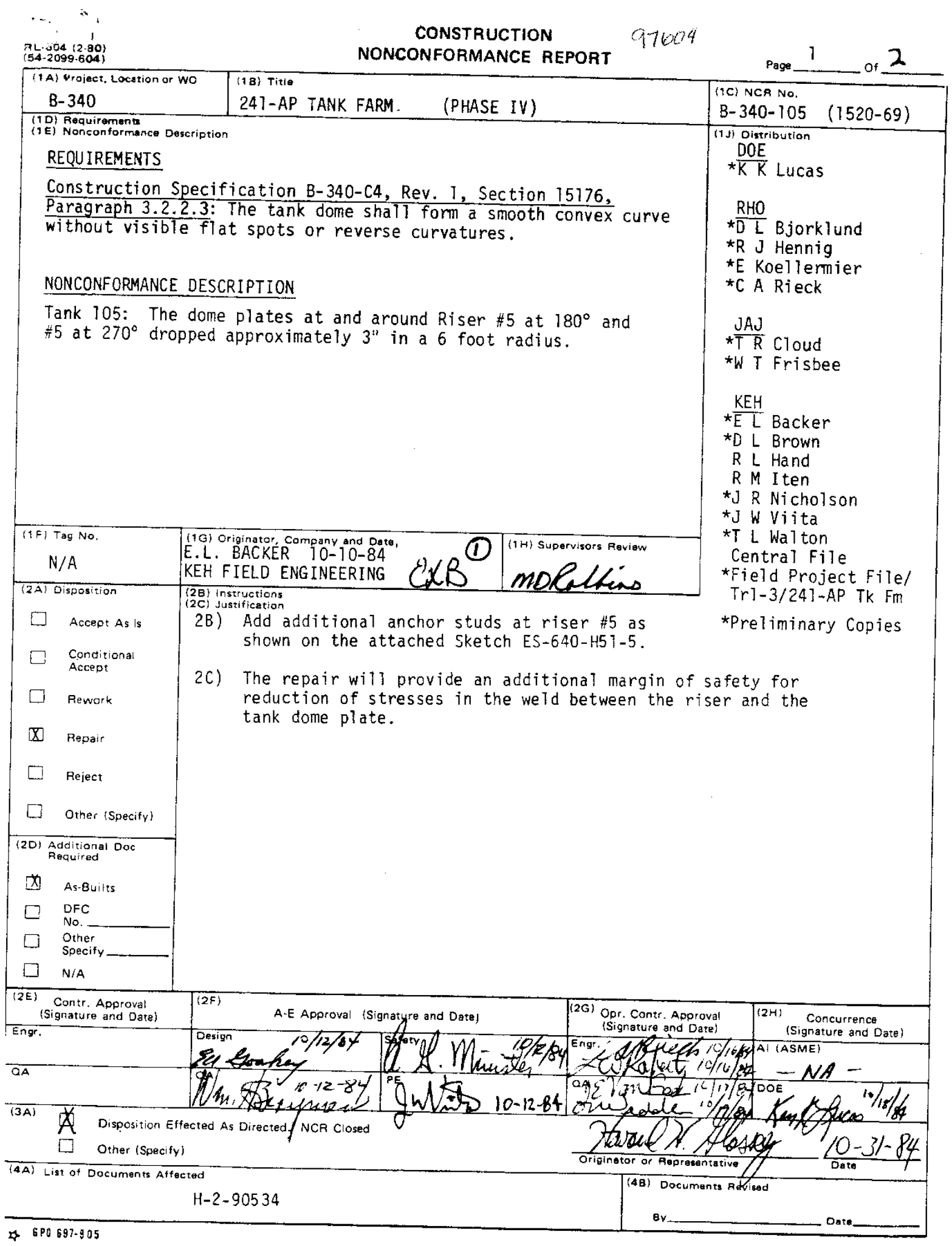


RPP-RPT-55983, Rev. 0

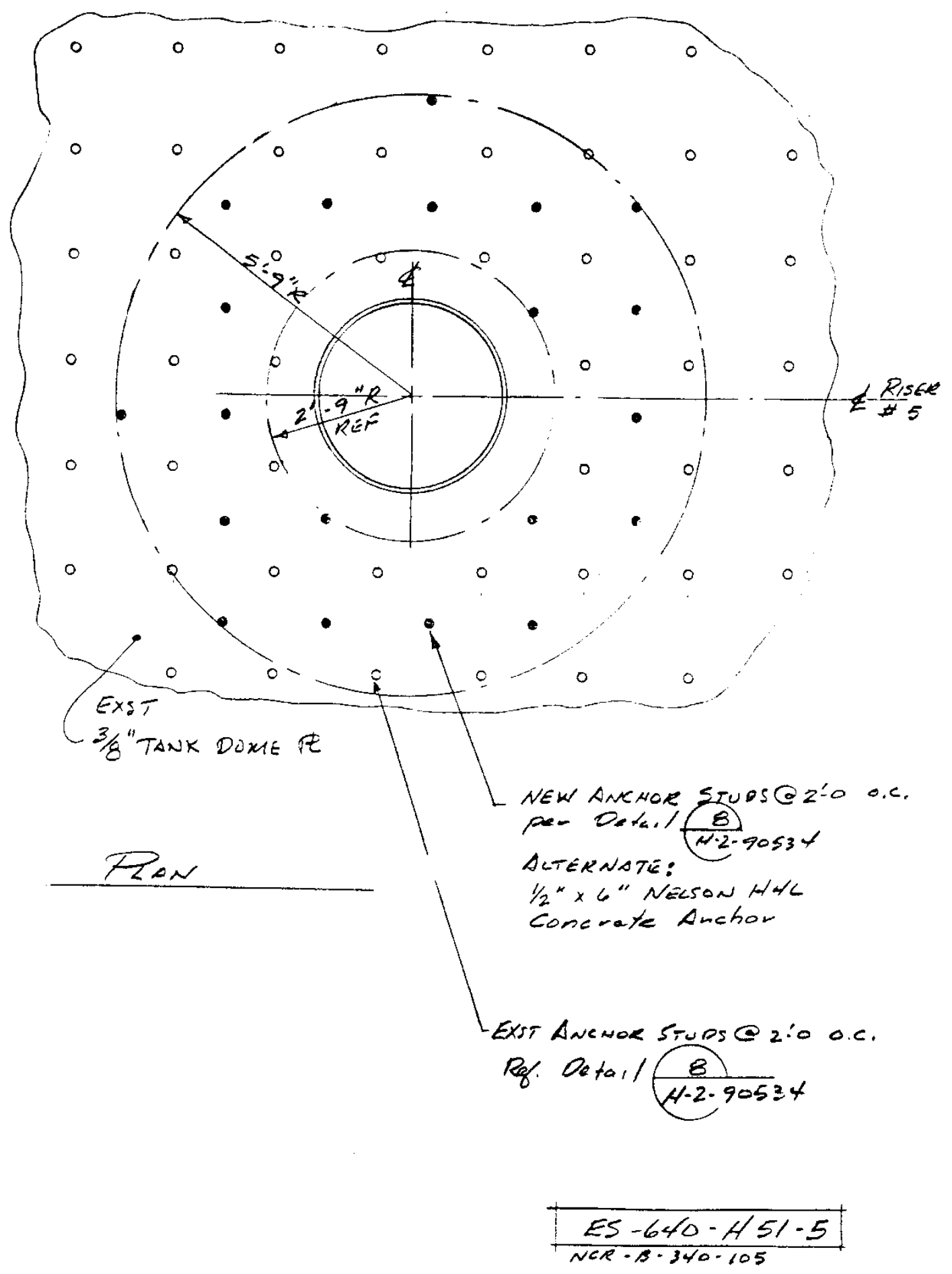


RPP-RPT-55983, Rev. 0

App. Figure B-23. Nonconformance Report B-340-13

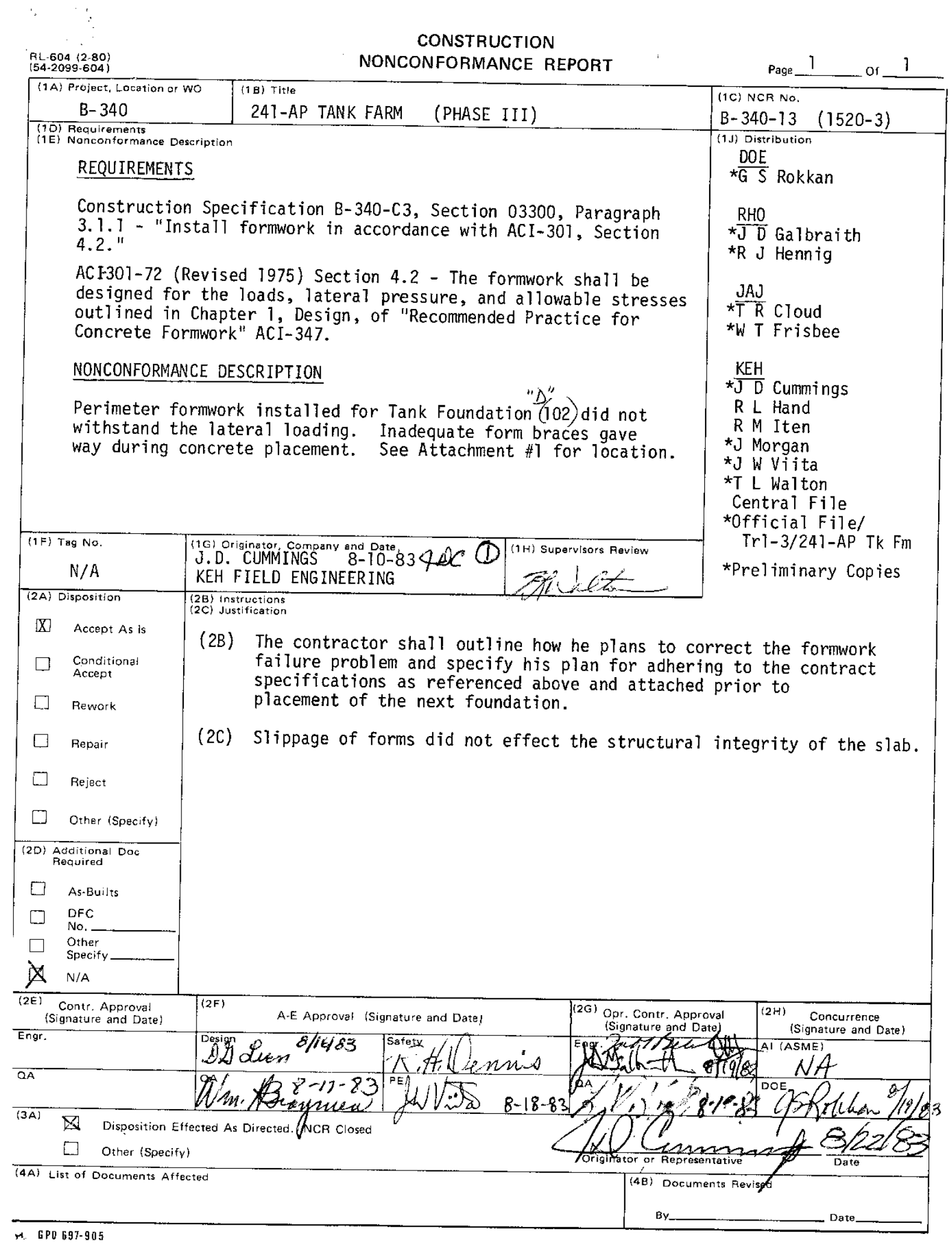


RPP-RPT-55983, Rev. 0

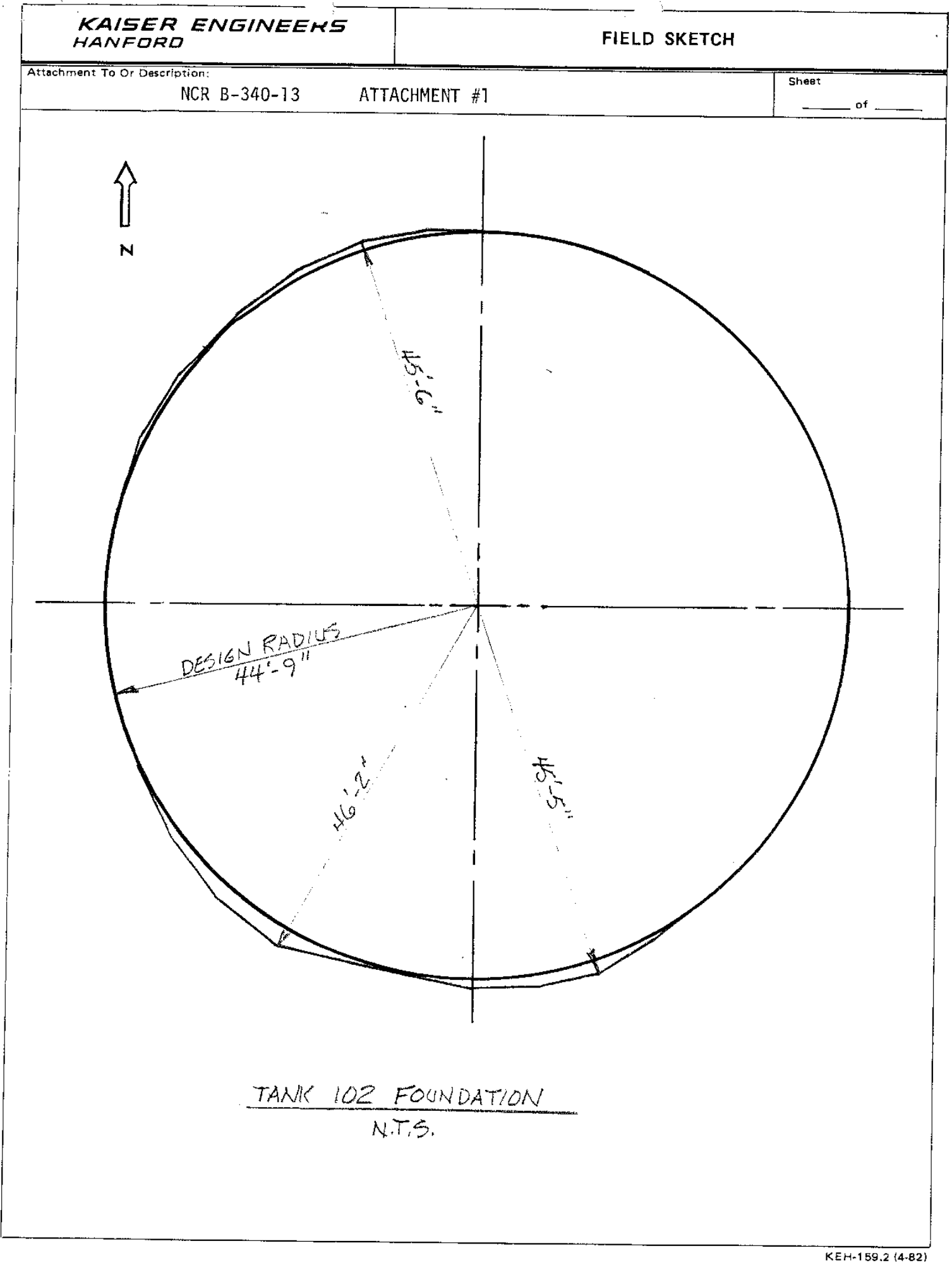


RPP-RPT-55983, Rev. 0

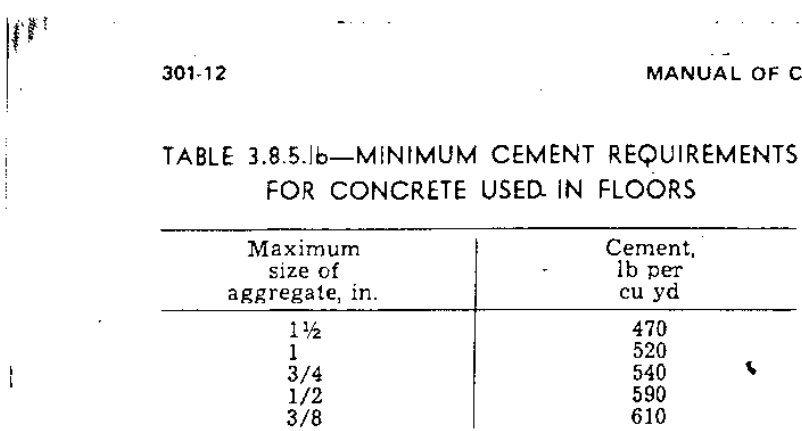

to be capable of being finished to the satisfaction of the architect/engineer at a slump not exceeding that given in Table 3.8.5.1a.

\section{Notes}

In the sections of Chapter 3 listed below, specific approval is required:

3.6 To waive limitations on maximum aggregate size.

3.7.2 Of protective measures which will permit waiving the limitation on chloride ion content.

3.8.2.2 For mixture proportions.

\section{CHAPTER 4-FORMWORK}

\section{1-Ceneral*}

4.1.1-Forms shall be used, wherever necessary, to confine the concrete and shape it to the required dimensions. Forms shall have sufficient strength to withstand the pressure resulting from placement and vibration of the concrete, and shall have sufficient rigidity to maintain specified tolerances.

4.1.2-Additional formwork requirements for concrete are described in Chapter 10, Finishing of Formed Surfaces; Chapter 11, Slabs; Chapter 13. Architectural Concrete; and Chapter 15, Prestressed Concrete.

4.1.3-Earth cuts shall not be used as forms for vertical surfaces unless required or permitted.

4.1.4-Shop drawings for formwork including the location of shoring and reshoring shall be submitted for approval as required by the contract documents.

\section{2-Design and installation of formwork}

4.2.1-The design and engineering of the formwork, as well as its construction, shall be the responsibility of the contractor.

4.2.2-The formwork shall be designed for the loads, lateral pressure, and allowable stresses outlined in Chapter 1, Design, of "Recommended Practice for Concrete Formwork" (ACI 347) and for design considerations, wind loads, allowable stresses, and other applicable requirements of the controlling local building code.

Detailed recommendations are given in "Recommended
practice for Concrete Formwork" (ACI 347).
4.2.3-Requirements for facing materials are given in Chapter 10, Finishing of Formed Surfaces. The maximum deflection of facing materials reflected in concrete surfaces exposed to view shall be $1 / 240$ of the span between structural members.

4.2.4-Forms shall be sufficiently tight to prevent loss of mortar from the concrete. Chamfer strips shall be placed in the corners of forms to produce beveled edges on permanently exposed surfaces. Interior corners on such surfaces and the edges of formed joints will not require beveling unless required by the contract documents.

4.2.5-To maintain the specified tolerances, the formwork shall be cambered to compensate for anticipated deflections in the formwork prior to hardening of the concrete.

4.2.6-Positive means of adjustment (wedges or jacks) of shores and struts shall be provided and all settlement shall be taken up during concrete placing operation. Forms shall be securely braced against lateral deflections.

4.2.7-Temporary openings shall be provided at the base of column forms and wall forms and at other points where necessary to facilitate cleaning and observation immediately before concrete is placed.

4.2.8-Form accessories to be partially or wholly embedded in the concrete, such as ties and hangers, shall be of a commercially manufactured type. Nonfabricated wire shall not be used.

Form ties shall be constructed so that the ends or end fasteners can be removed without causing appreciable spalling at the faces of the concrete.

After the ends or end fasteners of form ties have been removed, the embedded portion of the ties shall terminate not less than 2 diameters or twice the minimum dimension of the tie from the formed faces of concrete to be permanently exposed to view except that in no case shall this distance be less than 34 in. When the formed face of the concrete is not to be permanently exposed to view, form ties may be cut off flush with the formed surfaces.

4.2.9-At construction joints, contact surface of the form sheathing for flush surfaces exposed to view shall overlap the hardened concrete in the previous placement by not more than 1 in. The forms shall be held against the hardened concrete to prevent offsets or loss of mortar at the construction joint and to maintain a true surface.

4.2.10 - Wood forms for wall openings shall be constructed to facilitate loosening, if necessary, to counteract swelling of the forms.

4.2.11 - Wedges used for final adjustment of the forms prior to concrete placement shall be fastened in position after the final check.

4.2.12 - Formwork shall be so anchored to shores or other supporting surfaces or members that 
TABLE 4.3.1-TOLERANCES FOR FORMED SURFACES

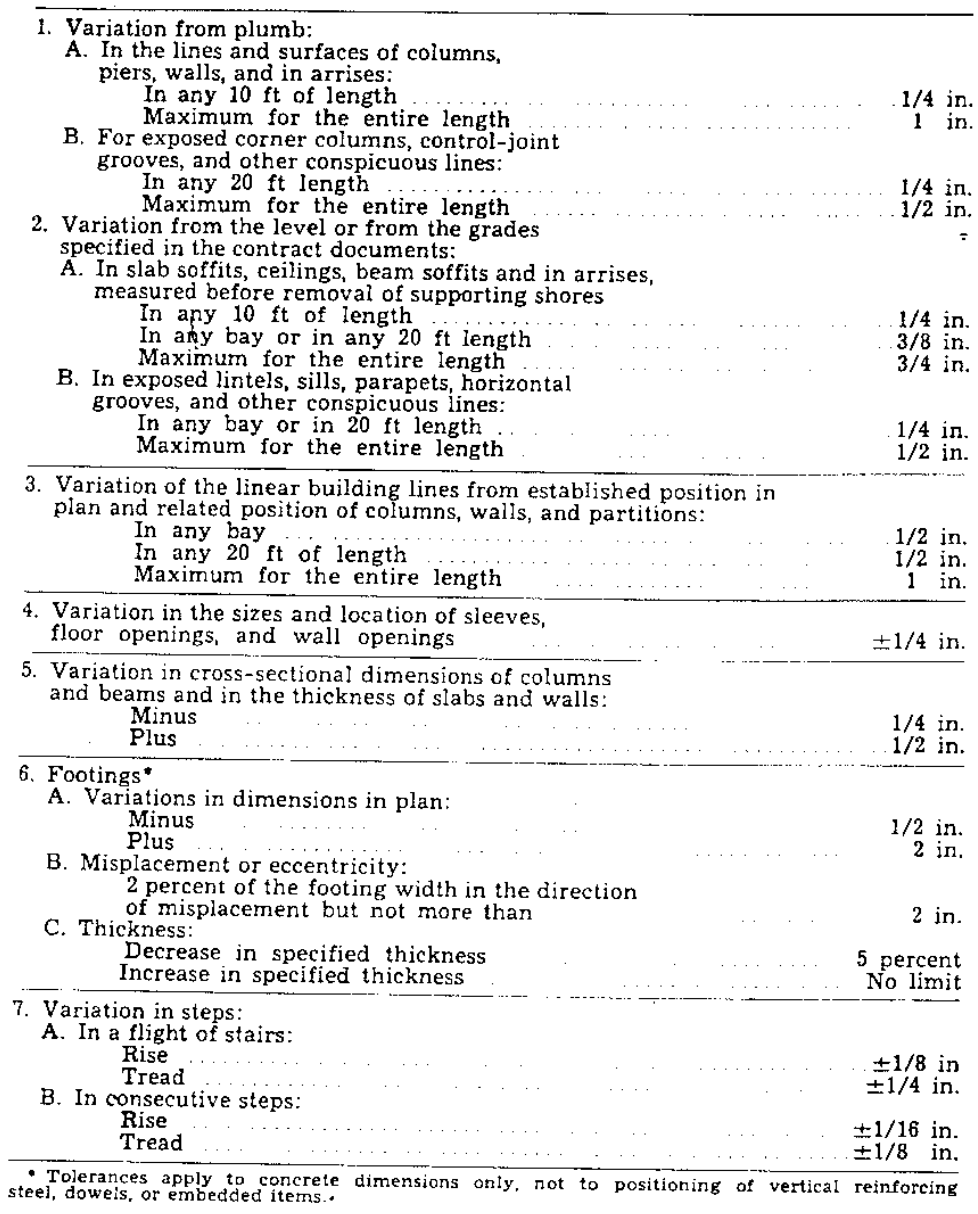

upward or lateral movement of any part of the formwork system during concrete placement will be prevented.

4.2.13-Runways for moving equipment shall be provided with struts or legs and shall be supported directly on the formwork or structural member without resting on the reinforcing steel.

\section{3-Tolerances}

4.3.1-Unless otherwise specified by the architect/engineer, formwork shall be constructed so that the concrete surfaces will conform to the tolerance limits listed in Table 4.3.1.

4.3.2-The contractor shall establish and maintain in an undisturbed condition and until final completion and acceptance of the project sufficient control points and bench marks to be used for reference purposes to check tolerances.

4.3.3-Regardless of the tolerances listed in Table 4.3.1, no portion of the building shall ex- tend beyond the legal boundary of the project.

4.3.4-Permissible variations from plumb and designated building lines for portions of buildings more than $100 \mathrm{ft}$ above the ground shall be as specified in the contract documents.

\section{4-Preparation of form surfaces}

4.4.1-All surfaces of forms and embedded materials shall be cleaned of any accumulated mortar or grout from previous concreting and of all other foreign material before concrete is placed in them.

4.4.2-Unless otherwise specified or approved, surfaces of forms shall be treated as follows:

4.4.2.1 Before placing of either the reinforcing steel or the concrete, the surfaces of the forms shall be covered with an approved coating material that will effectively prevent absorption of moisture and prevent bond with the concrete, and will not stain the concrete surfaces. A field 
measurement after initial set and before decentering -

(g) Special requirements for post-tensioned concrete members. The effect of load transfer during tensioning of post-tensioned members may be critical, and the contractor should be advised of any special provisions that must be made in the formwork for this condition

(h) If camber is desired for slab soffits or structural members to compensate for elastic deflection and/or deflection due to creep of the concrete, the contract drawings must so indicate and state the amounts. Measurement of camber attained should be made after initial set and before removal of formwork supports

(i) Where chamfers are required on beam soffits or column corners, they should be specified (j) The contract documents of the engineer/ architect must cover in detail any requirements for inserts, waterstops, built-in frames for openings, holes through concrete, and similar requirements were work of other trades will be attached to, supported by, or passed through formwork

(k) Where architectural features, embedded items, or the work of other trades could change the location of structural members such as joists in one-way or two-way joist systems such changes or conditions should be coordinated by the engineer/architect

(1) The ACI Building Code (ACI 318) requirement that structural drawings show the live load used in the design.

\section{CHAPTER 2-DESIGN}

\section{1-General}

2.1.1 Planning-Any form regardless of size should be planned in every particular prior to its construction. The amount of planning required will depend on the size, complexity, and importance (considering reuses) of the form. A design analysis should be made for all formwork. Stability and buckling should be investigated in all cases.

2.1.2 Formwork drawings-Before constructing forms, the contractor, if required, will submit detailed drawings and/or design calculations of proposed formwork for review and/or approval by the engineer/architect or approving agency. If such drawings are not in conformity with contract documents as determined by the engineer/ architect or approving agency, the contractor will make such changes as may be required prior to start of work.

The review and/or approval of the formwork drawings in no way relieves the contractor of his responsibility for adequately constructing and maintaining the forms so that they will function properly. Such review and/or approval indicates that the assumed design loadings in combination with design stresses shown; proposed construction methods; placement rates, equipment, and sequences; the proposed form materials; and the overall scheme of formwork are deemed capable of producing the desired concrete in an acceptable manner. All major design values and loading conditions should be shown on formwork drawings. These include assumed values of live load; rate of placement, temperature, height and drop of be operated on formwork; foundation pressure; design stresses; camber diagrams; and other pertinent information, if applicable.

In addition to specifying types of materials, sizes, lengths, and connection details, formwork drawings should provide for applicable details such as:

(a) Procedures, sequence, and timing for removal of forms, shores, and reshores, if this is critical

(b) Design allowance for construction loads on new slabs should be shown when such allowance will affect the development of shoring and/ or reshoring schemes (see Sections 2.5.3 and 3.7 for shoring and reshoring of multistory structures)

(c) Anchors, form ties, shores, and braces

(d) Field adjustment of form during placing of concrete

(e) Waterstops, keyways, and inserts

(f) Working scaffolds and runways

(g) Weephole or vibrator holes where required

(h) Screeds and grade strips

(i) Crush plates or wrecking plates where stripping may dảmage concrete

(j) Removal of spreaders or temporary blocking

(k) Cleanout holes and inspection openings

(l) Construction joints, control joints, and expansion joints to conform to design drawings [ACI Building Code (ACI 318) ]

(m) Sequence of concrete placement and minimum elapsed time between adjacent placement

(n) Chamfer strips or grade strips for exposed corners and construction joints

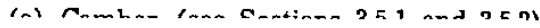


(p) Mudsills or other foundation provisions for formwork

(q) Special provisions such as safety, fire, drainage, and protection from ice and debris at water crossings

(r) Formwork coatings

(s) Notes to formwork erector for conduits and pipes embedded in concrete according to ACI Building Code (ACI 3.18)

(t) Temporary openings or attachments for climbing crane or other material handling equipment

2.1.3 Design and erection-Formwork should be designed so that concrete slabs, walls, and other members will be of correct dimensions, shape, alignment, elevation, and position. Formwork should also be designed, erected, supported, braced, and maintained so that it will safely support all vertical and lateral loads that might be applied until such loads can be supported by the concrete structure. Vertical and lateral loads must be carried to the ground by the formwork system or by the in-place construction that has adequate strength for that purpose.

\section{2-Loads}

2.2.1 Vertical loads-Vertical loads consist of dead load and live load. The weight of formwork plus the weight of freshly placed concrete is dead load. The live load includes the weight of workmen, equipment, material storage, runways, and impact.

Vertical loads assumed for shoring and reshoring design for multistory construction must include all loads transmitted from the floors above as dictated by the proposed construction schedule. Refer to Section 2.5, Shores.

Vertical supports and horizontal framing should be designed for a minimum live load of $50 \mathrm{psf}$ of horizontal projection. When motorized carts are used the minimum live load should be 75 psf.

The minimum design load for combined dead and live loads should be $100 \mathrm{psf}$, or $125 \mathrm{psf}$ if motorized carts are used.

2.2.2 Lateral pressure of concrete-For concrete made with Type I cement weighing $150 \mathrm{lb}$ per cu $\mathrm{ft}$, containing no pozzolans or admixtures, having slump $4 \mathrm{in}$. or less, and normal internal vibration, formwork should be designed for a lateral pressure of fresh concrete as follows, where

$$
\begin{aligned}
p= & \text { lateral pressure, } \mathrm{psf} \\
R= & \text { rate of placement, } \mathrm{ft} \text { per } \mathrm{hr} \\
T= & \text { temperature of concrete in the forms, } \\
& \text { deg } \mathrm{F} \\
h= & \text { height of fresh concrete above point } \\
& \text { considered, } \mathrm{ft}
\end{aligned}
$$

(a) For columns:

$$
p=150+9000 R / T
$$

(maximum of $3000 \mathrm{psi}$ or $150 \mathrm{~h}$, whichever is least)

(b) For walls, rate of placement not exceeding $7 \mathrm{ft}$ per $\mathrm{hr}$

$$
p=150+9000 R / T
$$

(maximum of 2000 psf or $150 h$, whichever is least)

(c) For walls, rate of placement 7 to $10 \mathrm{ft}$ per hr

$$
p=150+43,400 / T+2800 R / T
$$

(maximum of $2000 \mathrm{psf}$ or $150 \mathrm{~h}$, whichever is least)

(d) For walls, rate of placement greater than $10 \mathrm{ft}$ per $\mathrm{hr}$

$$
p=150 h
$$

(e) Where retarding admixtures are employed, an effective value of temperature less than that of the concrete in the forms should be used in the above formulas. Refer to specific admixture manufacturer's recommendations.

(f) Appropriate adjustment for lateral pressures should be made when using concretes weighing other than $150 \mathrm{lb}$ per cu ft; containing pozzolans, admixtures, or cements other than Type I; or external vibration of forms. ${ }^{1-3}$

(g) For slipform lateral pressures, see Section 6.3.2.3.

2.2.3 Horizontal loads-Braces and shores should be designed to resist all foreseeable horizontal loads such as wind, cable tensions, inclined supports, dumping of concrete, and starting and stopping of equipment. Wind loads on enclosures or other wind breaks attached to the formwork should be considered in addition to those loads mentioned above.

2.2.3.1 For building construction, in no case should the assumed value of horizontal load due to wind, dumping of concrete, and equipment acting in any direction at each floor line be less than $100 \mathrm{lb}$ per lineal $\mathrm{ft}$ of floor edge or 2 percent of total dead load on the form distributed as a uniform load per lineal foot of slab edge, whichever is greater.

2.2.3.2 Wall forms should be designed to meet wind load requirements of the local building code. The minimum wind design load should be 15 psf, unless local codes specifically permit less. Bracing for wall forms should be designed for a horizontal load of at least $100 \mathrm{lb}$ per lineal $\mathrm{ft}$ of wall, applied at the top.

2.2.3.3 Wall forms of unusual height or exposure should be given special consideration.

2.2.4 Special loads-The formwork should be designed for any special conditions of construction likely to occur, such as unsymmetrical placement of concrete, impact of machine- 
RPP-RPT-55983, Rev. 0

delivered concrete, uplift, concentrated loads of reinforcement, and storage of construction materials. Form designers should be alert to provide for special loading conditions, such as walls constructed over spans of slabs or beams which exert a different loading pattern before hardening of concrete than that for which the supporting structure is designed.

Imposition of any construction loads on the partially completed structure should not be allowed except with the approval of the engineer or architect. See Section 3.8 for special conditions pertaining to multistory work.

\section{3-Unit stresses}

Unit stresses for use in the design of formwork, exclusive of accessories, are given in the applicable codes or specifications listed in Chapter 4. When fabricated formwork, shoring, or scaffolding units are used, manufacturer's recommendations for allowable loads may be followed if supported by test reports or successful experience records; for formwork materials which will experience substantial reuse, reduced values may be required. For formwork materials with limited reuse, allowable stresses specified in the appropriate design codes or specifications for temporary structures or for temporary loads on permanent structures may be used. Where there will be a considerable number of formwork reuses or where formwork is fabricated from materials such as steel, aluminum, or magnesium, it is recommended that the formwork be designed as a permanent structure carrying permanent loads

\section{4-Safety factors for accessories}

Table 2.4 shows recommended minimum factors of safety for formwork accessories such as form ties, form anchors, and form hangers. In selecting these accessories the formwork designer should be certain that materials furnished for the job meet these minimum ultimate strength safety requirements.

\section{5-Shores}

2.5.1 General-Shores are defined as vertical or inclined support members designed to carry the weight of formwork, concrete, and construction loads above. When patented shores, patented splices in shoring, or patented methods of shoring are used, manufacturer's recommendations as to load-carrying capacities may be followed but only if supported by test reports of a qualified and recognized testing agency. The formwork designer must carefully follow the manufacturer's recommendations as to bracing and working loads for unsupported shore lengths.

2.5.2 Splices-Field-constructed butt or lap
TABLE 2.4-MINIMUM SAFETY FACTORS OF FORMWORK ACCESSORIES*

\begin{tabular}{|c|c|c|}
\hline Accessory & $\begin{array}{l}\text { Safety } \\
\text { factor }\end{array}$ & Type of construction \\
\hline \multirow{2}{*}{ Form tie } & 1.5 & $\begin{array}{l}\text { Light formwork, } 8 \text { ft or less } \\
\text { in height with no hazard to } \\
\text { life }\end{array}$ \\
\hline & 2.0 & $\begin{array}{l}\text { All formwork over } 8 \mathrm{ft} \text { in } \\
\text { height or hazardous to Jife. } \\
\text { Formwork for architectural } \\
\text { concrete }\end{array}$ \\
\hline \multirow{2}{*}{ Form anchor } & 2.0 & $\begin{array}{l}\text { Formwork supporting form } \\
\text { weight and concrete pres- } \\
\text { sures only }\end{array}$ \\
\hline & 3.0 & $\begin{array}{l}\text { Formwork supporting } \\
\text { weight of forms, concrete, } \\
\text { construction live loads, and } \\
\text { impact }\end{array}$ \\
\hline Form hangers & 2.0 & All applications \\
\hline $\begin{array}{l}\text { Anchoring inserts } \\
\text { used as form ties }\end{array}$ & 2.0 & $\begin{array}{l}\text { Precast concrete panels } \\
\text { when used as formwork }\end{array}$ \\
\hline
\end{tabular}

unless they are made using fabricated hardware devices of demonstrated strength and stability. If plywood or lumber splices are made for timber shoring, they should be designed against buckling and bending as for any other structural compression member.

2.5.3 Multistory structures - Shores should be designed to carry the full weight of the concrete and formwork and construction loads of all floors above them prior to the removal of the first story of shores supported by the ground. No shoring should be removed until the concrete has gained sufficient strength to support the loads which will be transferred to the structure upon removal of such shoring.

Once the first floor of shores supported by the ground has been removed, shores and reshores must be designed to carry all loads transmitted from the slabs above. Shores in no case should be designed to carry less than one and one-half times the weight of a given floor of concrete, formwork and construction loads. ${ }^{2-1.2-2}$ In determining the number of floors to be shored or reshored, the factors to be considered should include but not necessarily be limited to the following:

1. Design load capacity of the slab or member including live load, partition loads, and other loads for which the engineer designed the slab. Where the engineer included allowances for construction loads, such values should be shown on the structural drawings

2. Dead load weight of the concrete and formwork

3. Construction live loads, such as placing crews 
RPP-RPT-55983, Rev. 0

App. Figure B-24. Nonconformance Report B-340-14

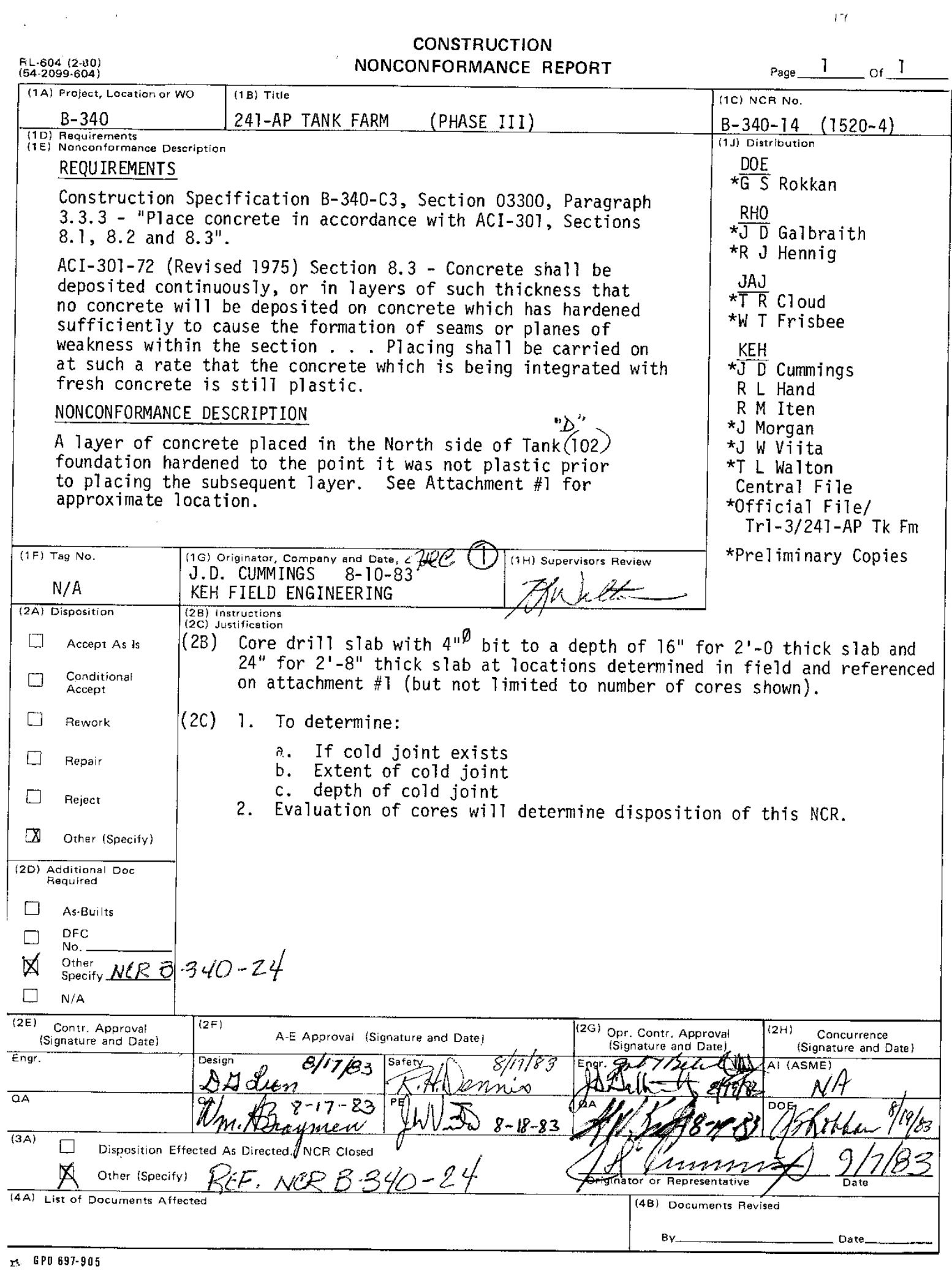


RPP-RPT-55983, Rev. 0

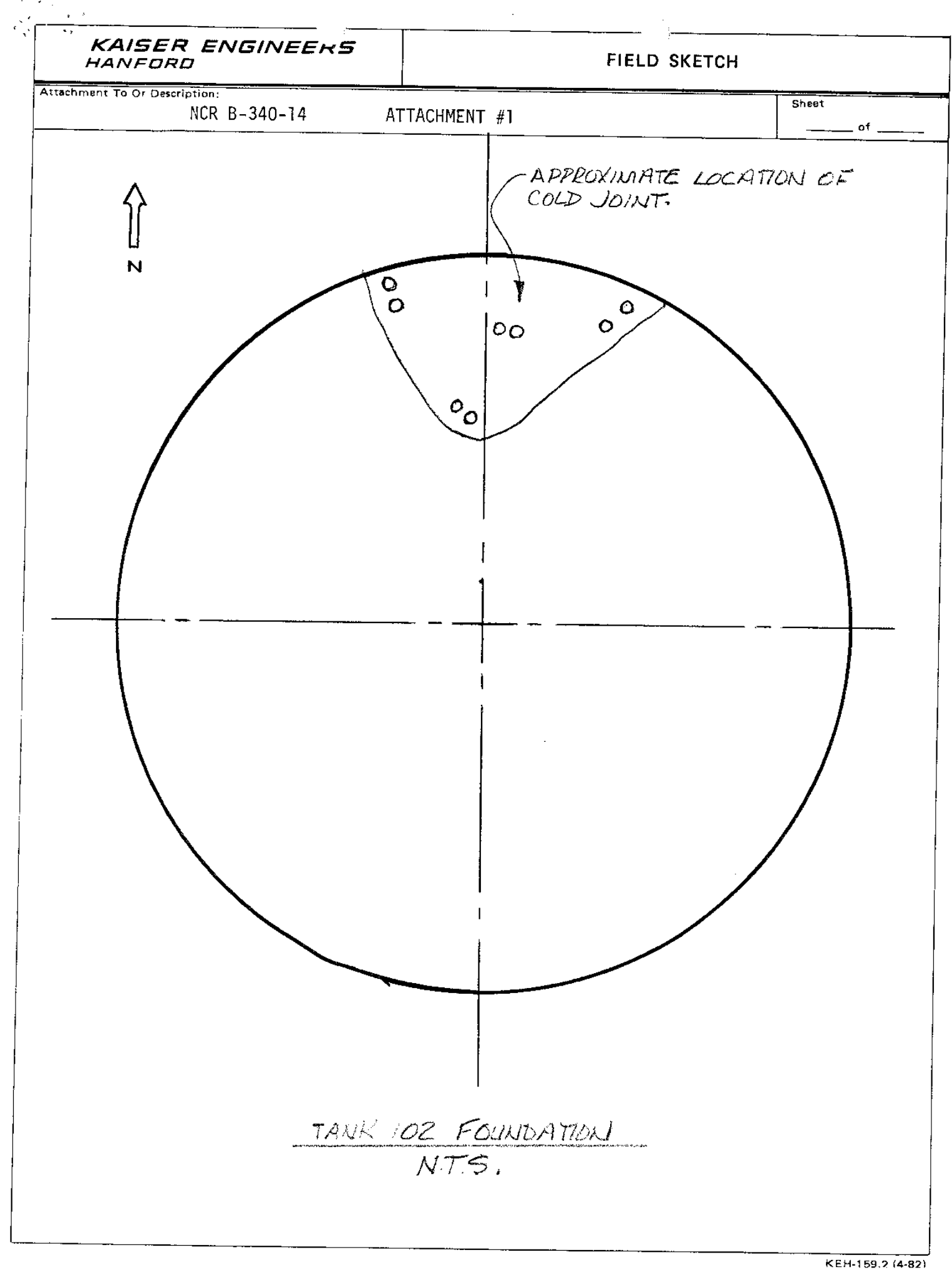


RPP-RPT-55983, Rev. 0

App. Figure B-25. Nonconformance Report B-340-15

$R L-604(2+r i)$
$(54-2099-6 i: 4)$

CONSTRUCTION

NONCONFORMANCE REPORT

\begin{tabular}{|l|l|}
\hline (1A) Project, Location or wo & (1B) Titte \\
B-340 & 24I-AP TANK FARM \\
\hline (1D) Requirements \\
(1E) Nonconformance Description \\
REQUIREMENTS \\
Construction Specification B-340-C3, Section 03300, Paragraph 3.3.3 - \\
"Place concrete in accordance with ACI-301, Sections $8.1,8.2$ \& 8.3."
\end{tabular}

ACI-301-72 (Revised 1975) Section 8.3:

8.3.3 Segregation - Concrete shall be deposited as nearly as practicable in its final position to avoid segregation due to rehanding or flowing. Concrete shall not be subjected to any procedure which will cause segregation.

8.3.4 Consolidation - All concrete shall be consolidated by vibration, spading, rodding or forking so that the concrete is thoroughly worked around the reinforcement, around embedded items, and into corners of forms, el iminating a 11 air or stone pockets which may cause honeycombing, pitting, or planes of weakness. Internal vibrators shall be operated by competent workmen. Use of vibrators to transport concrete within forms shall not be allowed. Vibrators shall be inserted and withdrawn at points approximately 18 in. apart. At each insertion (Continued on Page 2 of 2 )

\begin{tabular}{|c|c|c|}
\hline $\begin{array}{l}\text { (1F) Tag No. } \\
N / A\end{array}$ & $\begin{array}{l}\text { 3.b. COMMMINGS 8-10-83 } \$ 20 \mathrm{C} \\
\text { KEH FIELD ENGINEERING }\end{array}$ & (1H) Supervisors Review \\
\hline (2A) Disposition & $\begin{array}{l}\text { (2B) Instructions } \\
\text { (2C) Justification }\end{array}$ & \\
\hline D Accept As is & (2A) Disposition - Repair & \\
\hline
\end{tabular}

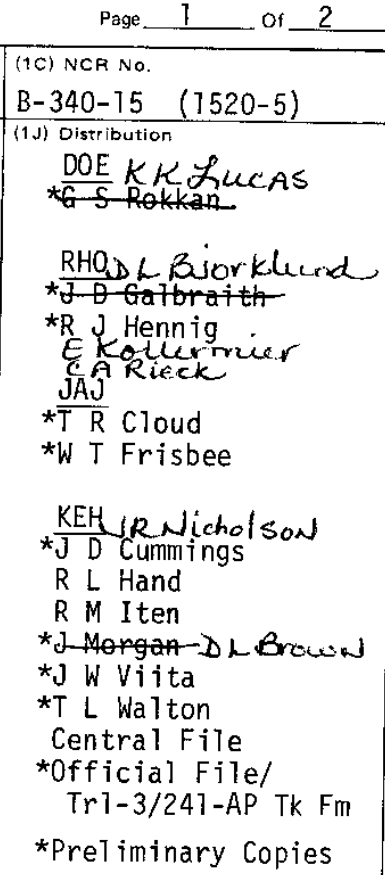

(2B) 1. Repair defect areas to contract specification requirements.

2. Contractor shall take appropriate action to insure that concrete placement and finishing is performed according to contract specification

$\square \quad$ Rework 3. Method of patching to be approved by the Goyt Rep prior to patching.

X Repair

(2C) Repair is required to meet contract specifications.
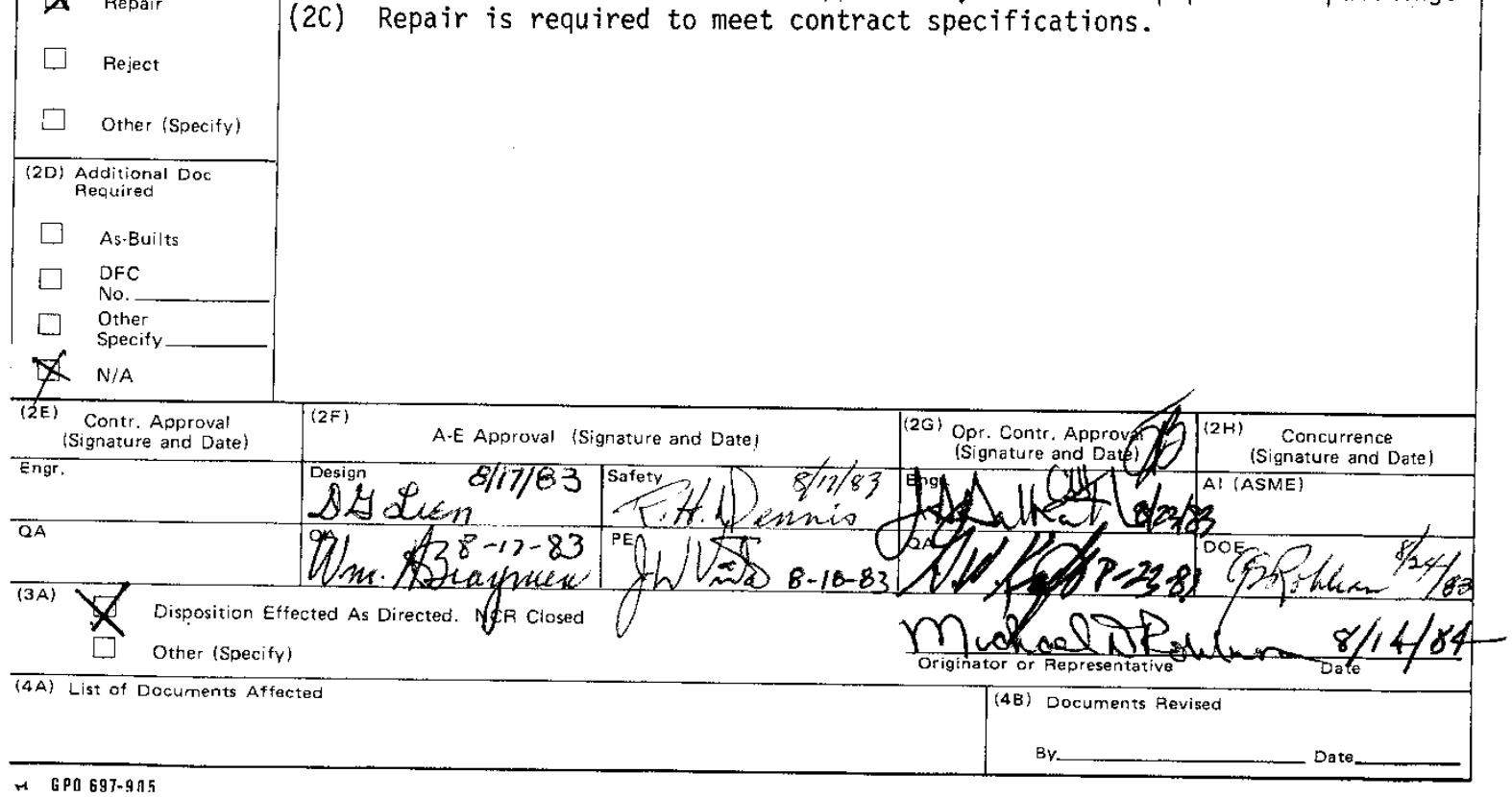

M GPO 697-995 
RPP-RPT-55983, Rev. 0

NCR B-340-15 (1520-5)

Page 2 of 2

(1D) REQUIREMENTS (continued)

the duration shall be sufficient to consolidate the concrete but not sufficient to cause segregation, generally from 5 to $15 \mathrm{sec}$.

ACI-301-72 (Revised 1975) Section 11.7.2 - Floated Finish - After the concrete has been placed, consolidated, struck off and leveled, float to a uniform sandy texture.

(IE) NONCONFORMANCE DESCRIPTION

"Do"

Concrete pour of Tank Foundation(102) on 8-9-83.

1. Internal vibrators were operated by inexperienced workmen. At several locations, concrete was deposited in large quantities in one area, and vibrators were used to transport concrete with in the forms. Some concrete received excessive vibration and others not enough.

Inadequate vibration was performed around embeds and forms causing air voids, and stone pockets. The embedded angles installed along the leak detection drain have voids under the angle at several locations.

2. The floated finish required for Tank Foundation 102 does not have a uniform sandy texture. At various locations, the surface is irregular and has air voids and visible surface aggregate.

NOTE: The contractor was repeatedly notified about problems associated with improper placement and consolidation. 
RPP-RPT-55983, Rev. 0

App. Figure B-26. Nonconformance Report B-340-17

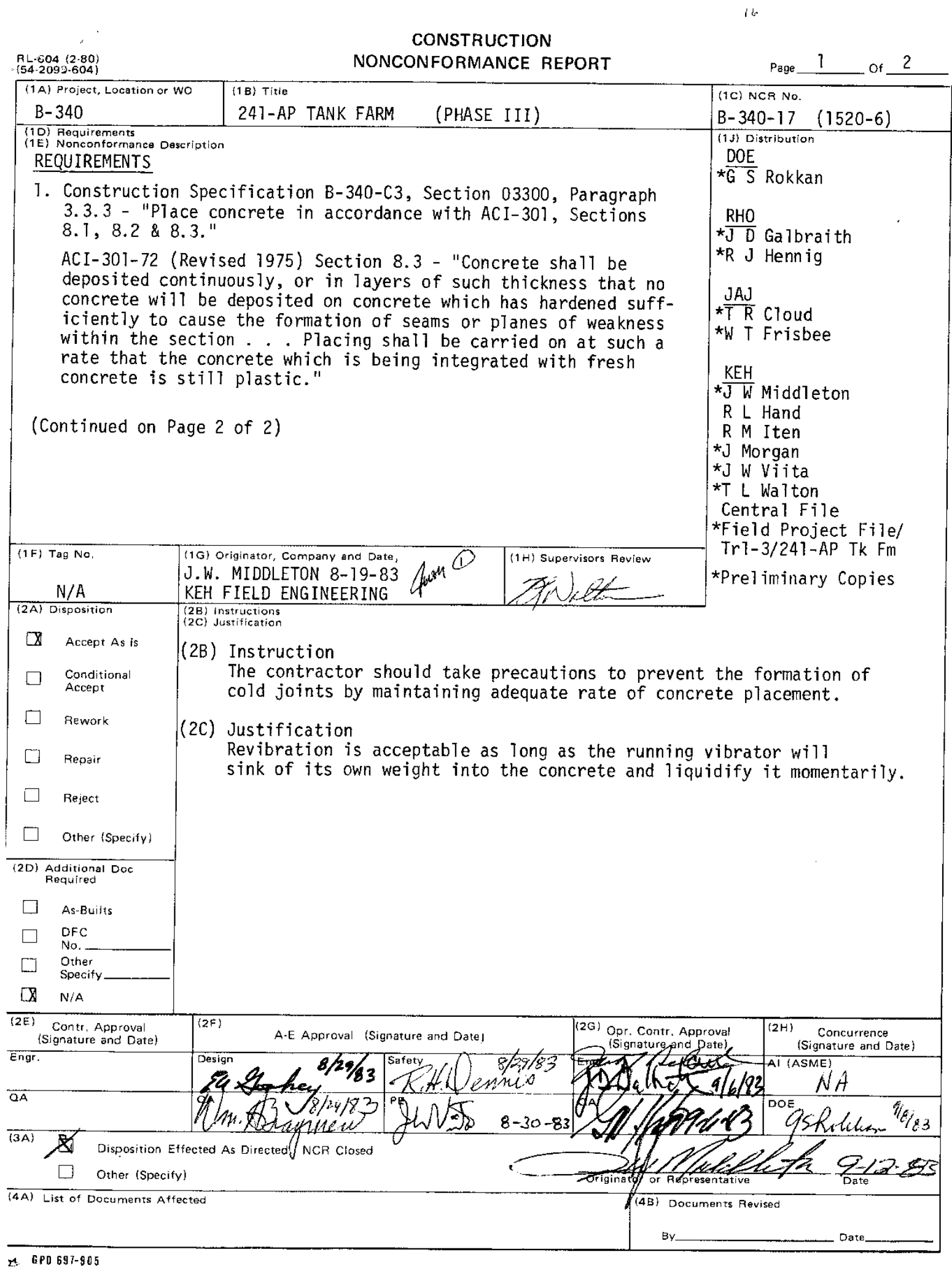


RPP-RPT-55983, Rev. 0

NCR B-340-17(1520-6)

Page 2 of 2

\section{NONCONFORMANCE DESCRIPTION}

1. At several large areas within the slab, the rate of concrete placement was not such that the concrete to be integrated with fresh concrete was still plastic.

Excessive over-vibration was used to re-establish plasticity of the hardening concrete prior to placement and integration with the subsequent layer of concrete.

Second and even third time re-vibration was employed to maintain plasticity of the concrete after the establishment of initial set.

See Attachment \#1 for approximate locations. 
RPP-RPT-55983, Rev. 0

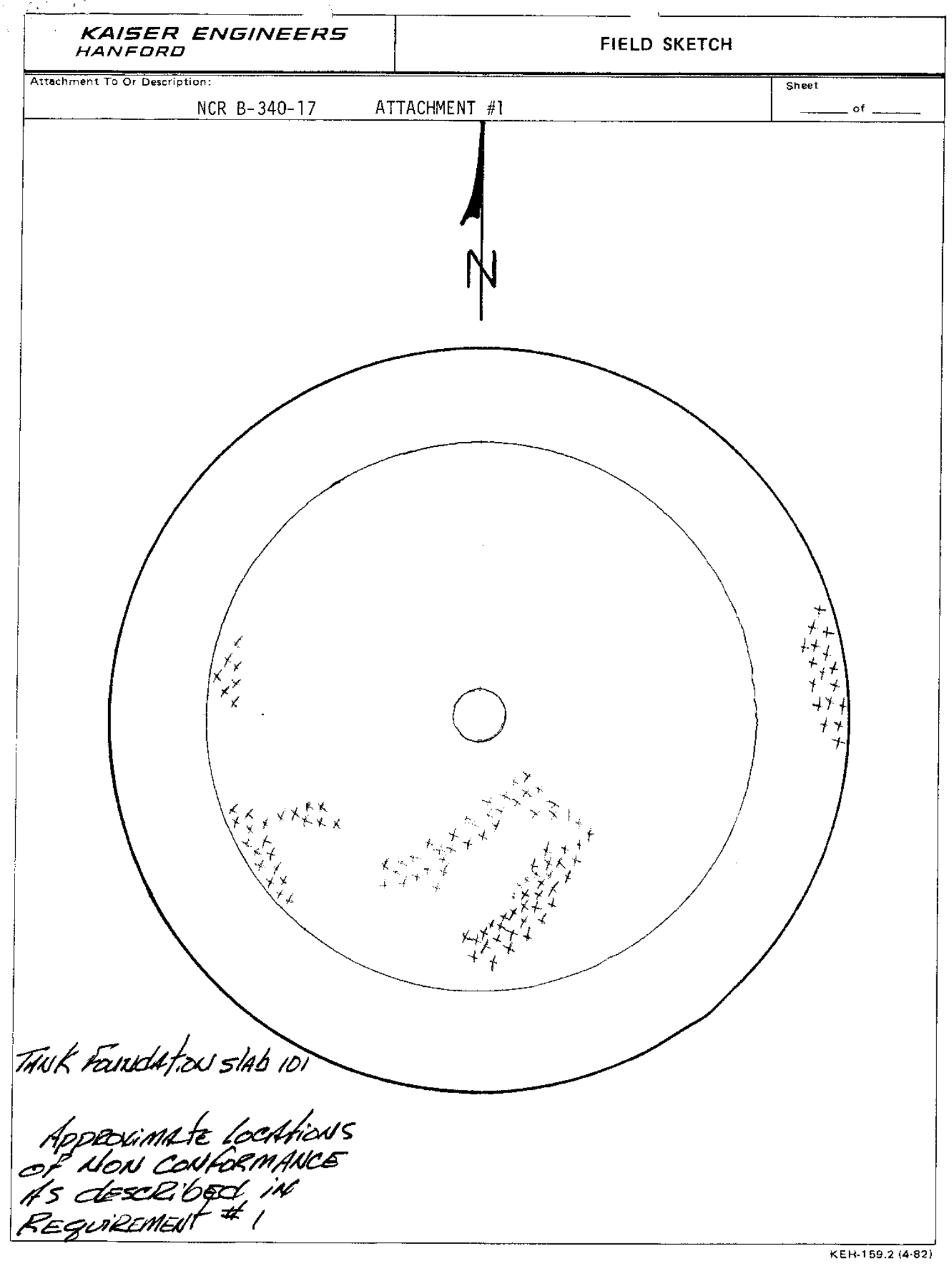


RPP-RPT-55983, Rev. 0

App. Figure B-27. Nonconformance Report B-340-21

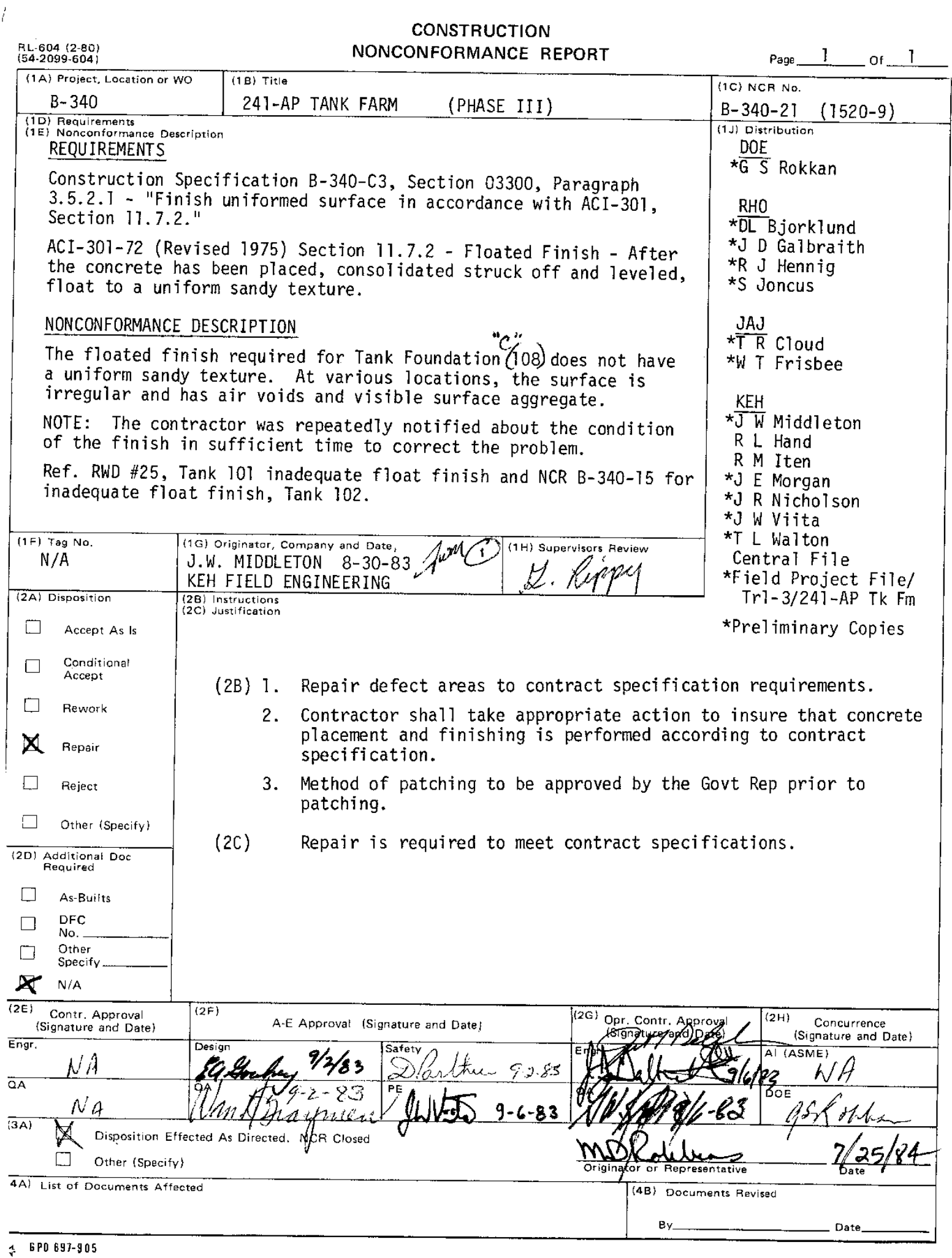


RPP-RPT-55983, Rev. 0

App. Figure B-28. Nonconformance Report B-340-23

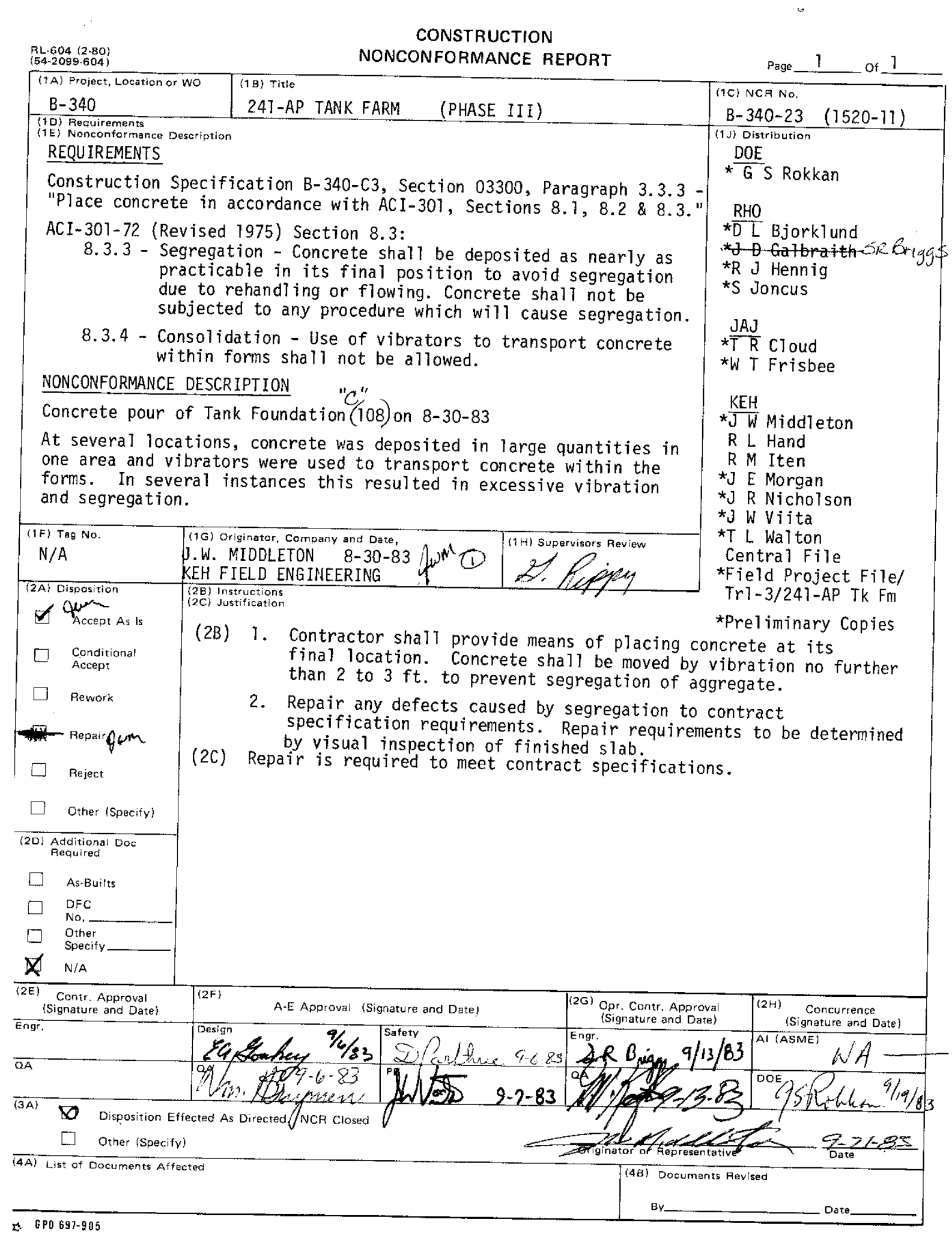


RPP-RPT-55983, Rev. 0

App. Figure B-29. Nonconformance Report B-340-24

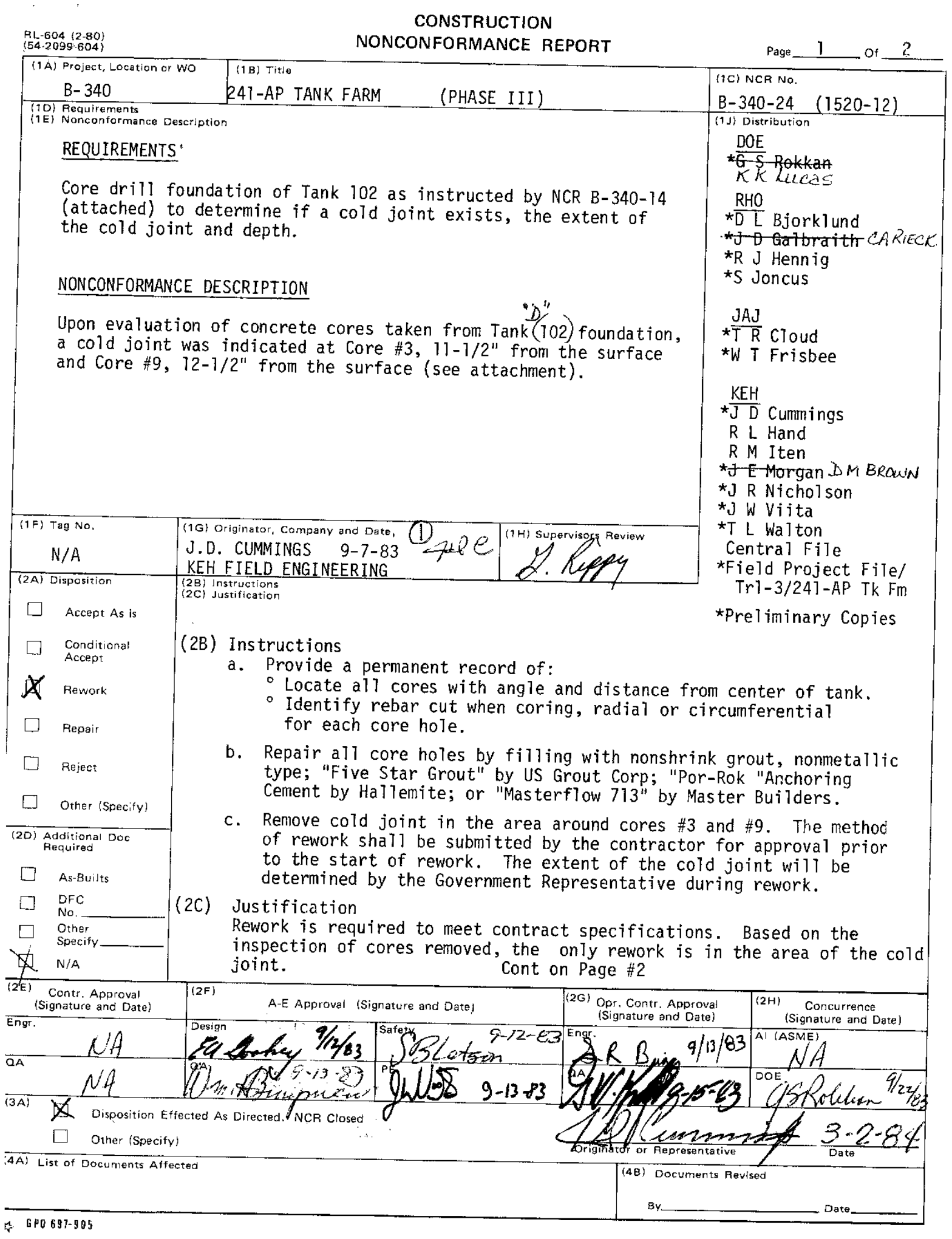


RPP-RPT-55983, Rev. 0

Pay_ 2 of 2

CONSTRUCTION NONCONFORMANCE REPORT B-340-24

(2C) Justification Cont.

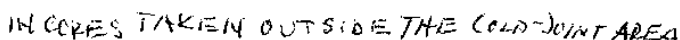

There is no evidence of rock pockets. A few large

$\left(1 / 2^{\prime \prime}\right.$ dia max.) air bubbles were seeh, but not of a frequency to effect the structural integrity of the concrete tank foundation. 
RPP-RPT-55983, Rev. 0

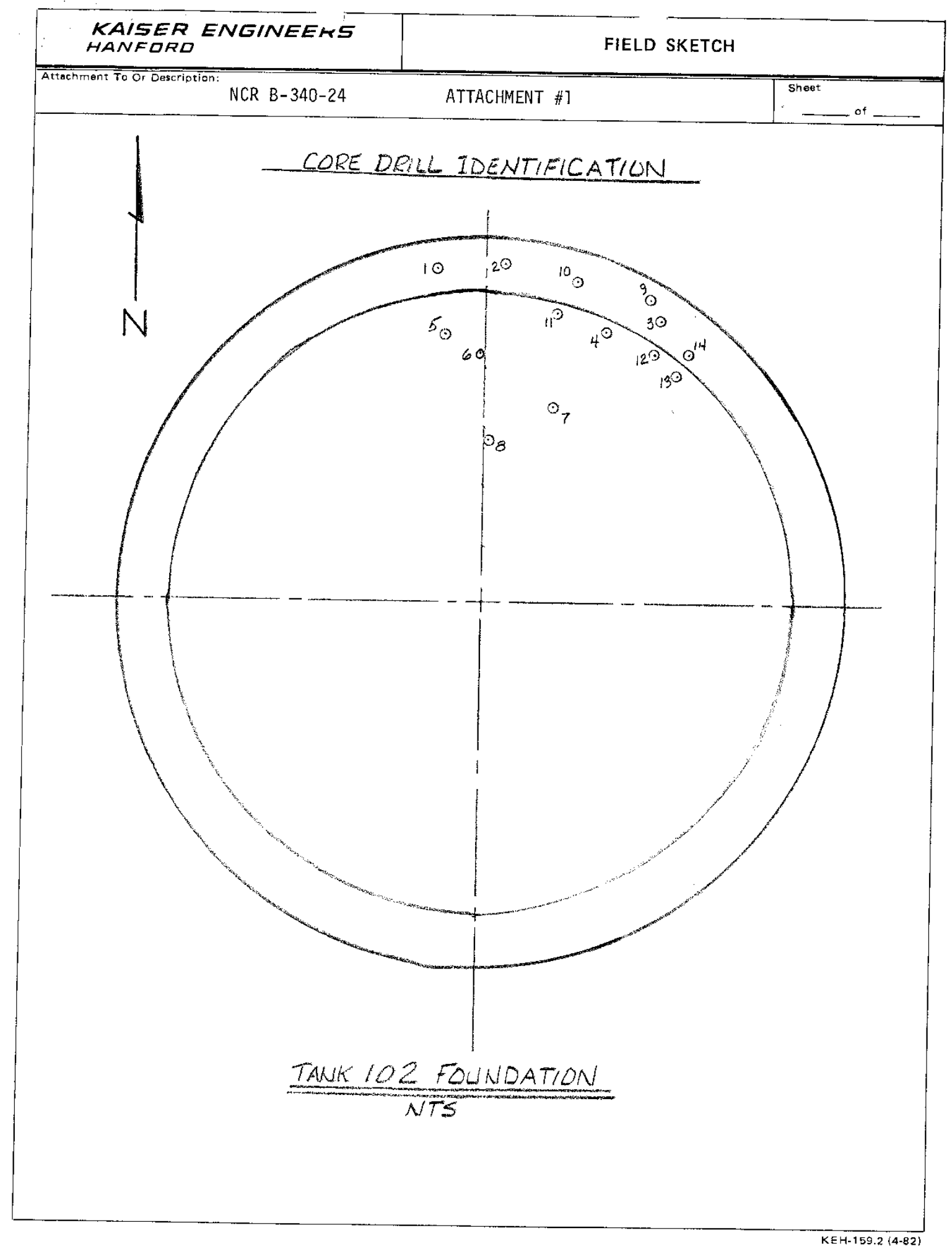


RPP-RPT-55983, Rev. 0

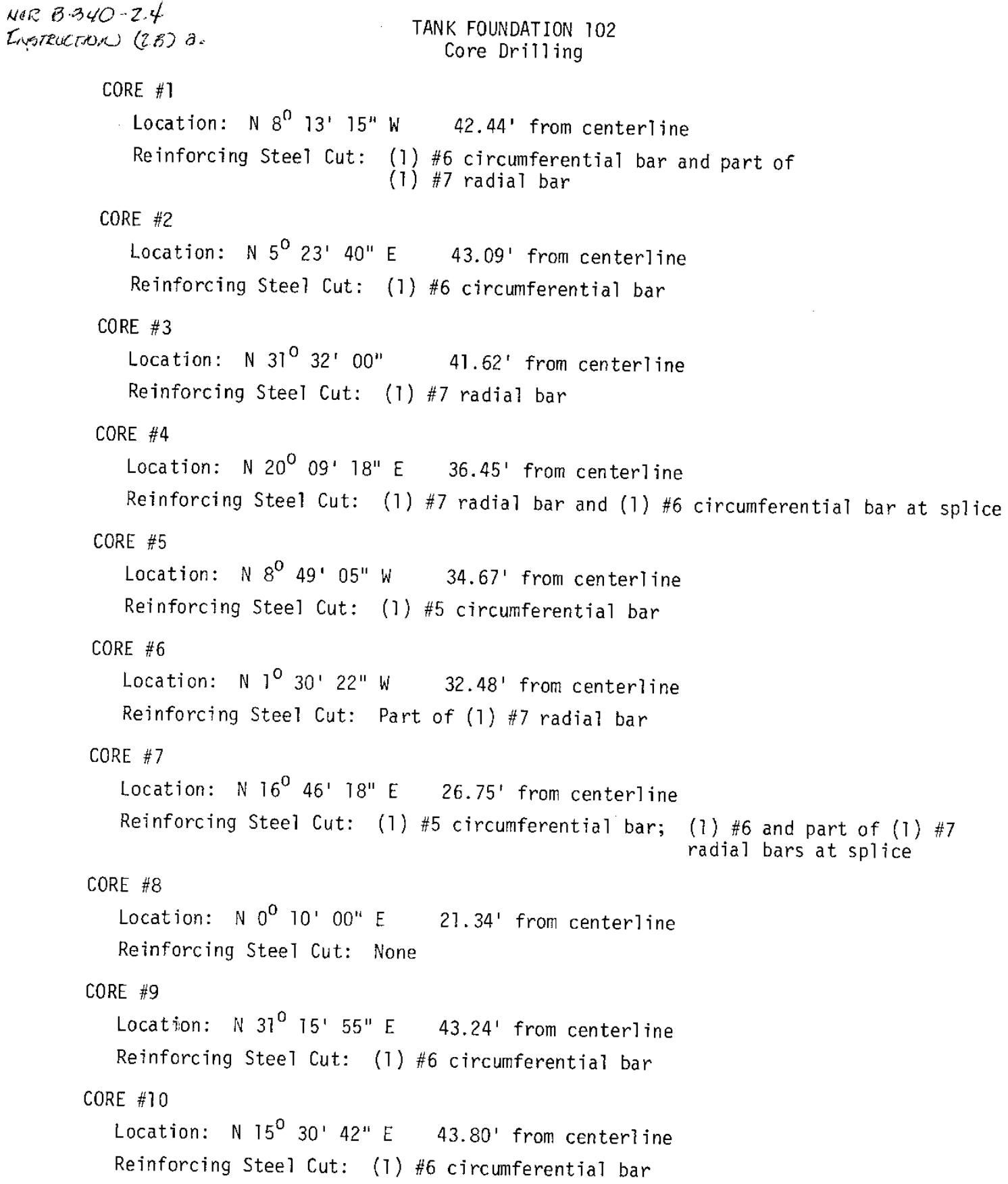


RPP-RPT-55983, Rev. 0

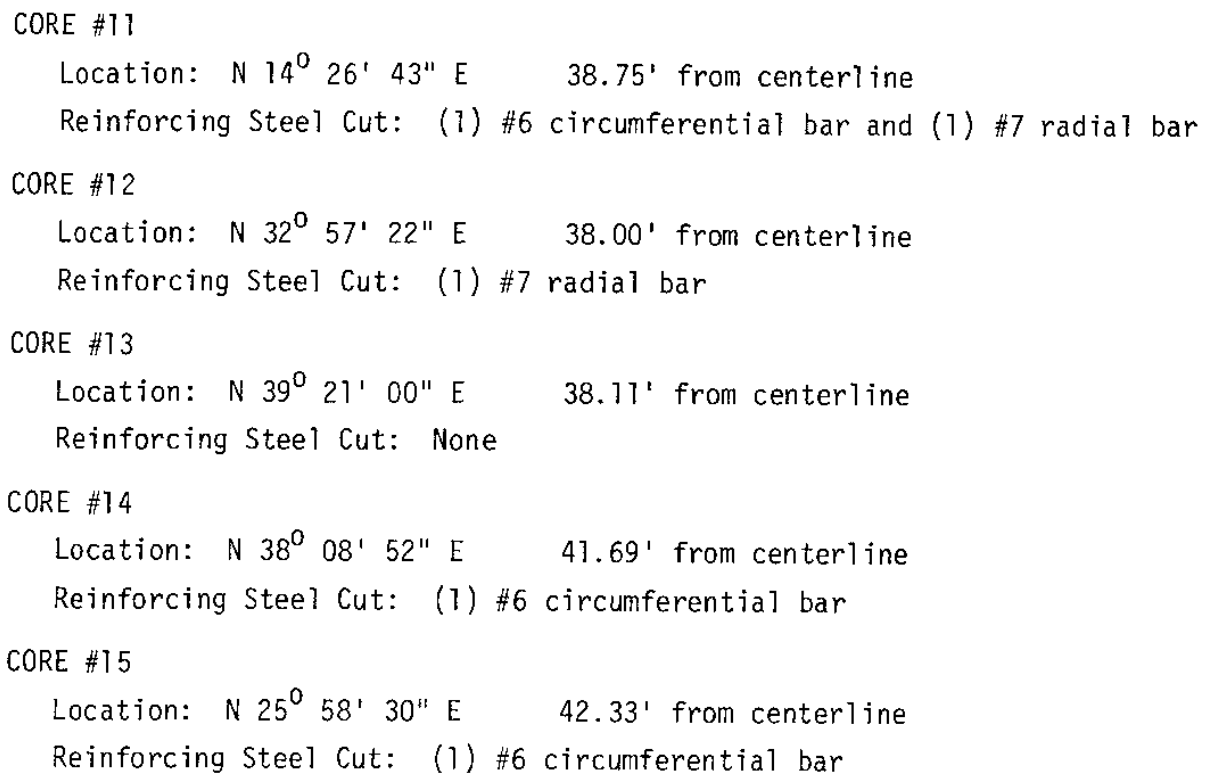


RPP-RPT-55983, Rev. 0

App. Figure B-30. Nonconformance Report B-340-29

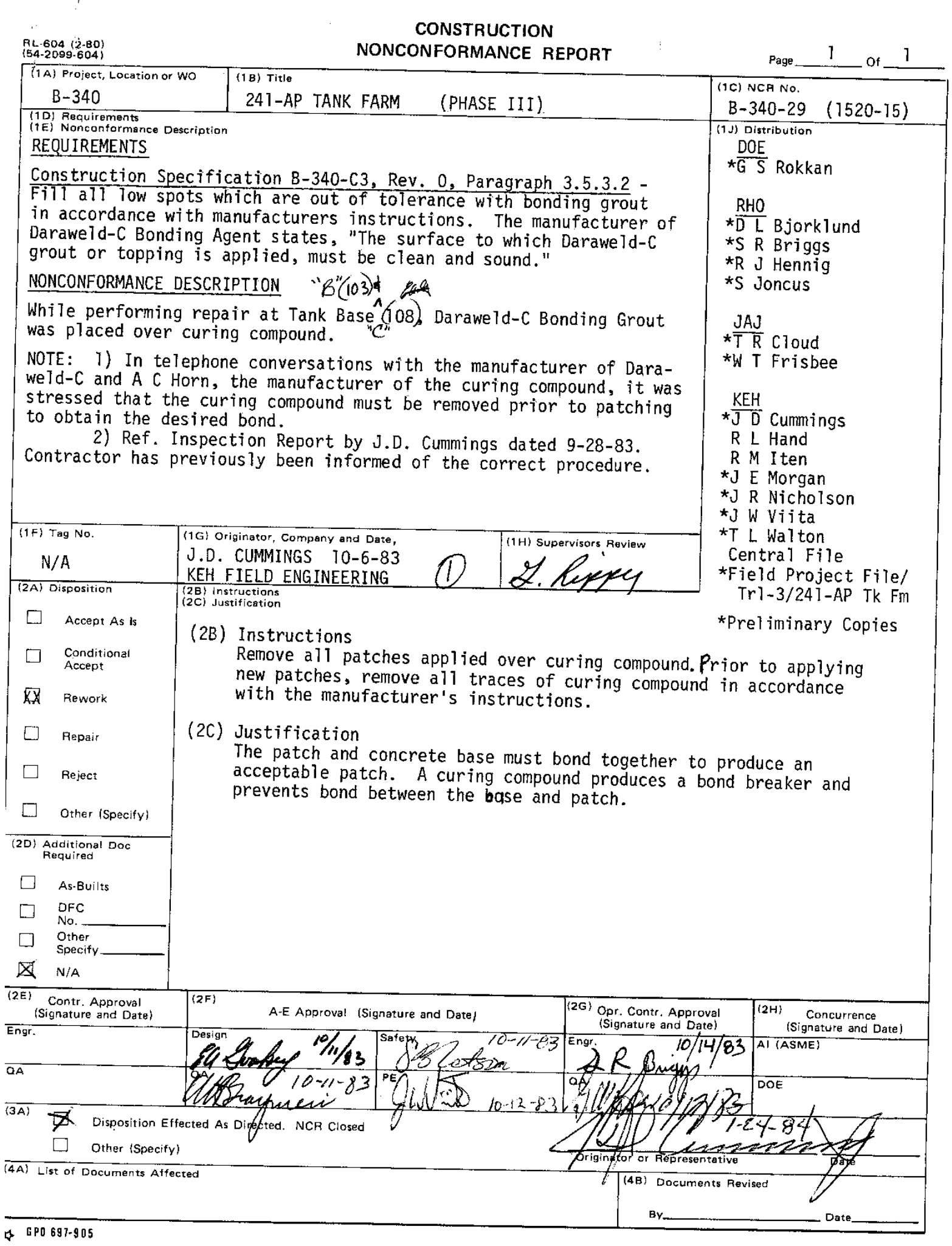


RPP-RPT-55983, Rev. 0

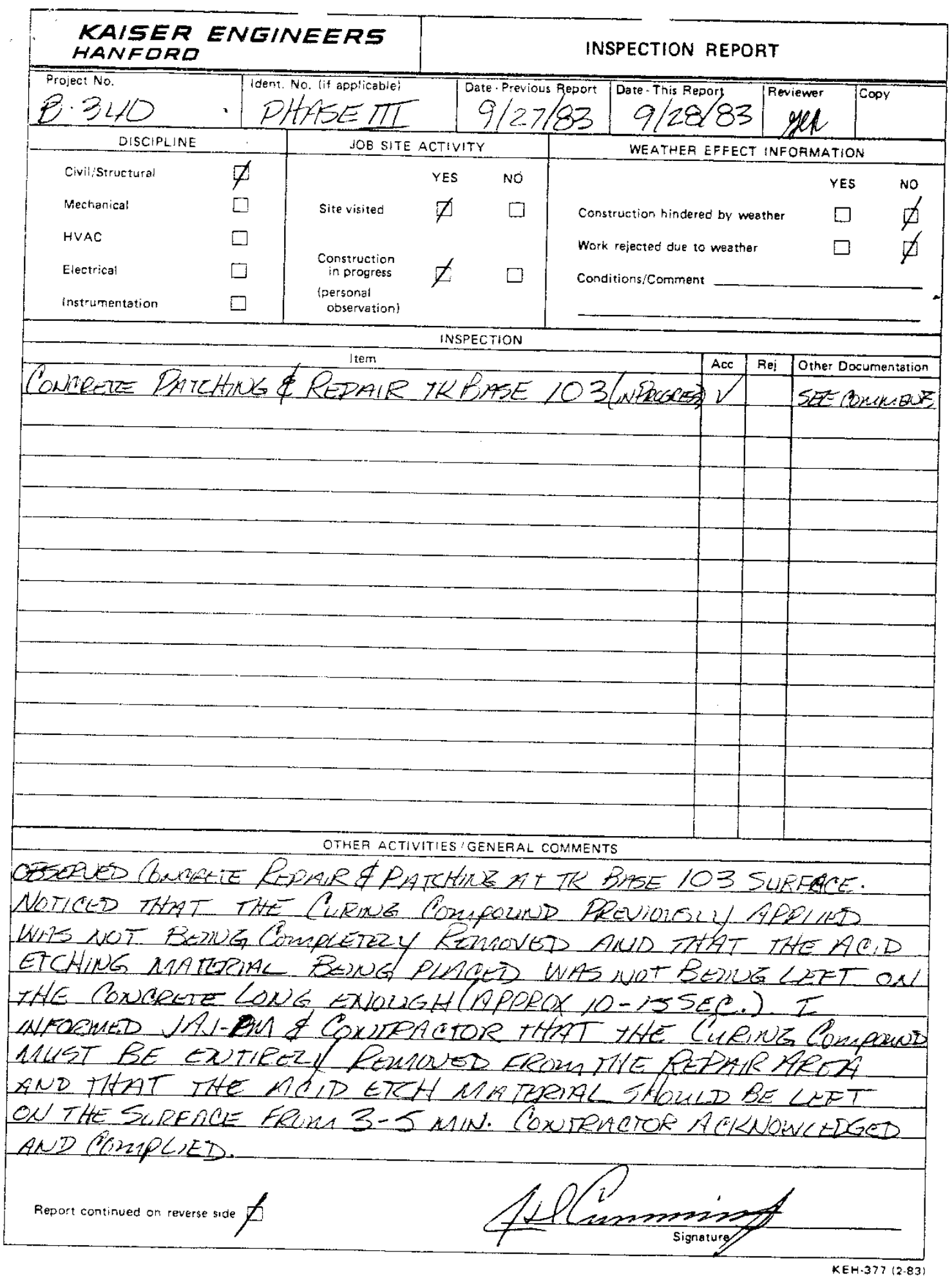


RPP-RPT-55983, Rev. 0
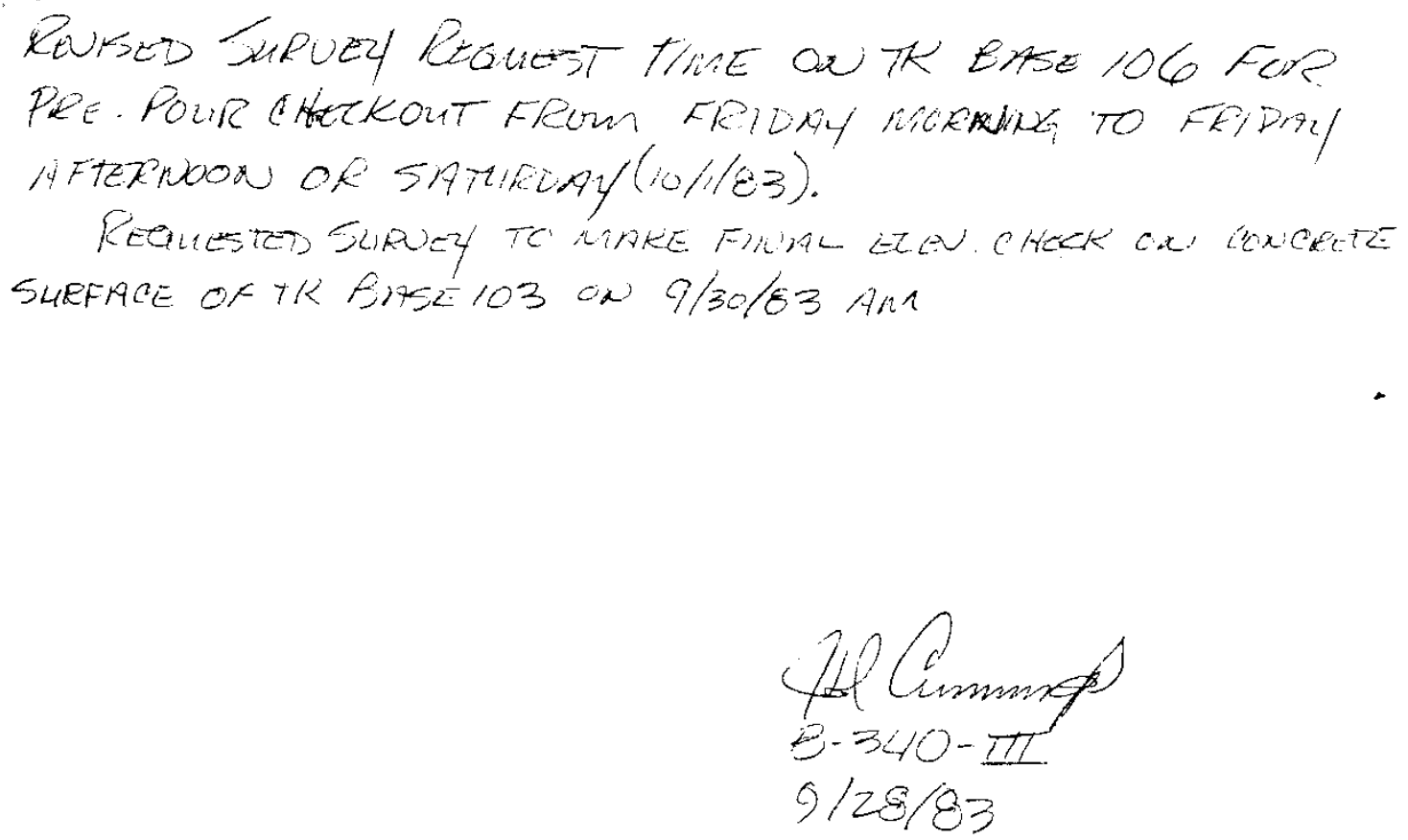
RPP-RPT-55983, Rev. 0

App. Figure B-31. Nonconformance Report B-340-30

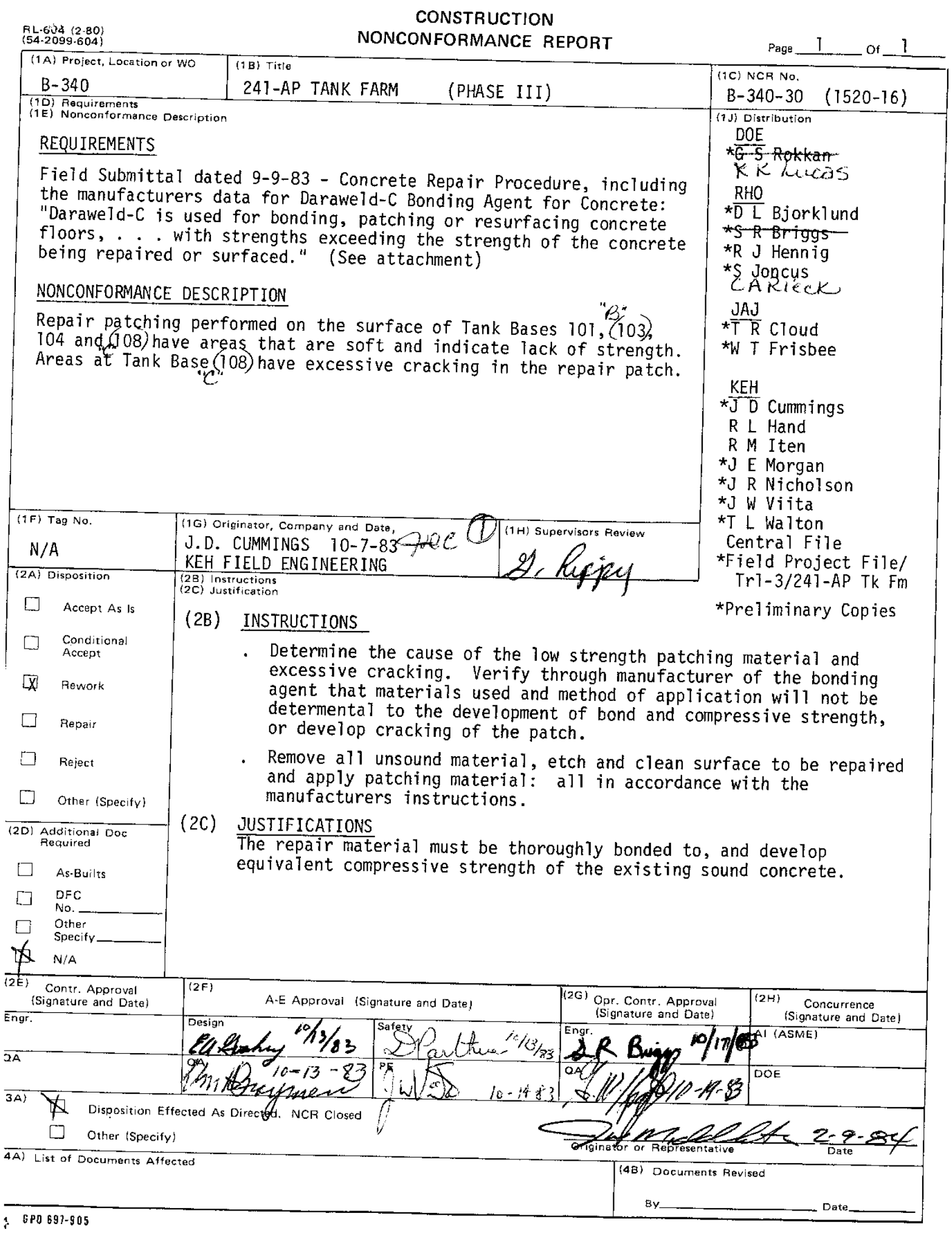




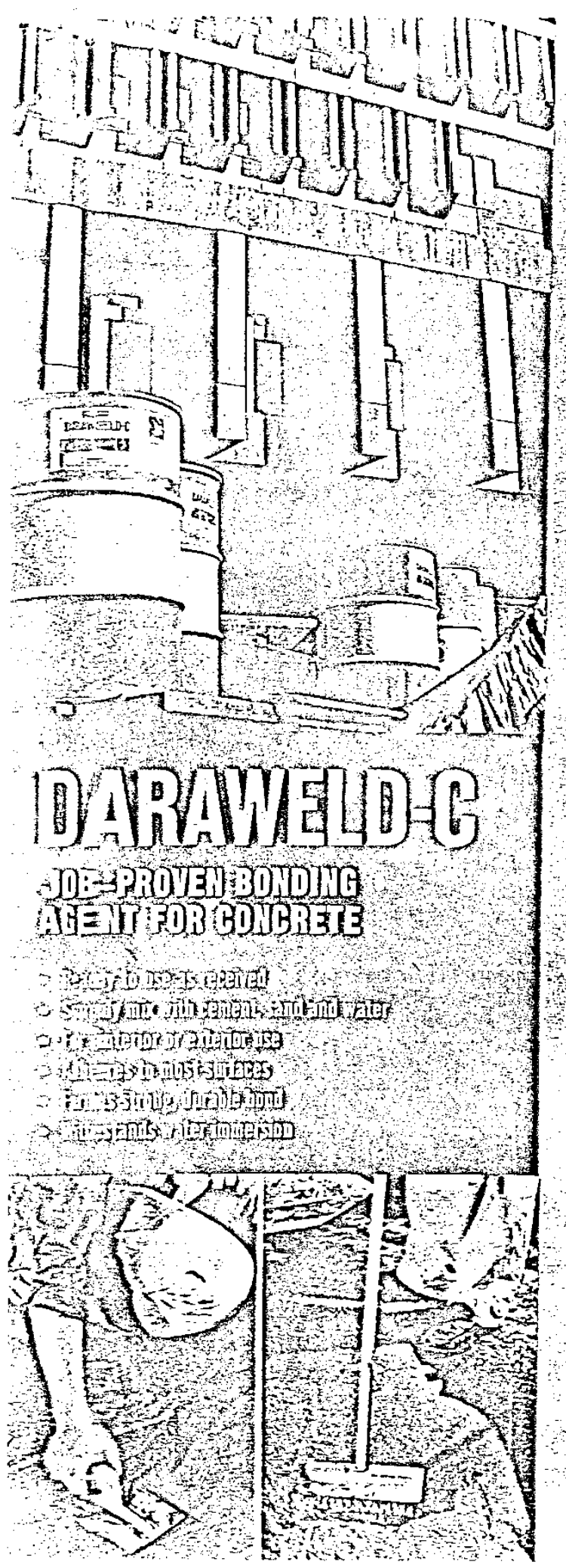

\section{UtSCRIFIIUN}

Daraweld-C is a nding agent for concrete. When used as directed $\mathrm{L}$ weld-C will form a bond between new to old, new to new, or old to old concrete stronges than the concrete being bonded, Daraweld-C is a dispersion of internally plasticized, high polymer resin in w'ater. It is a ready-to-use, pon-settling, milk white liquid with a viscosity only slightly greater than that of water and a reight of 9.0 pounds per gallon.

Mixed with cement and sand, Daraveld-C forms a strong, highly adhesive bonding grout which will adhere to most substrates. Daraweld-C is not re-emulsifiable and consequently the grout, when cured, will withstand iniermittent or continued exposure to water.

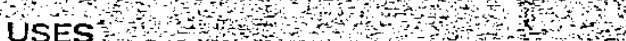

Daraweld-C is primarily intended for bonding new old or old to old portand cement concrete in exterior or interior applications. It is used for bonding, patching or resurfacing concrete floors, walls, beams, columns: or other structural members with strengths exceeding the strength of the concrete being repaired or resurfaced. Daraweld-C will substantially improve the adhesion of pneumatically applied mortar or concrete Because Daran'eld-C grouts and mortars will adhere: to most substrates, it bas been used in a nide variety of miscellaneous applications. These include repair of masonry structures, bonding construction joints, prevention of cold joints in multiple pours, leveling of floors prior to secondary surfacing skidproofing exist. ing foors, finishing concrete black walls, patching of stuccoed walls, striping or bonding to asphalt surfaces Daraweld-C grout is used to replace nubbing of concrete surfaces with a resulting waterproof, weatberproof uniform, and attractive finjsh at substantially lower cost

\section{SURFACE PREPARATION}

The surface to which Daraweld-C grout or topping is applied must be clean and sound. Remove oil, grease and similar substances w'ith Grease and Stain Remover, as required, used according to W. R. Grace \& Co.'s recommendations. Remove unsound concrete, loose material and foreign matter by scarifying or other mechanical means. All concrete whether new or old when cleaned, must be etched with a 1:1 munatic acid solution (approximately 14\%) and thoroughly rinsed. with water to remove all traces of acid. A properly prepared surface will be clean and sound, readily and uniformly wettable with water.

\section{MIXING AND PLACING}

\section{Bonding Grout:}

For all applications as a bonding agent Daraweld-C is mixed to the following proportions by weight or by volume:

$$
\begin{aligned}
& 1 \text { part Daraueld-C } \\
& 5 \text { parts portland cement } \\
& 2.5 \text { parts fine sand }
\end{aligned}
$$

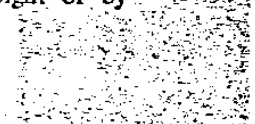

plus sufficient water to yield the desired consistency. A stitable sand will generally conform to the requirements. of ASTM C 144

In normal mixing the portland cement and saad are dry blended together, water and Daraweld-C are mixed together, added to the cement-sand blend and the whole thoroushly mixed by mechanical means. Up to 1 part of uater may be required depending upon the water 
RPP-RPT-55983, Rev. 0

App. Figure B-32. Nonconformance Report B-340-40

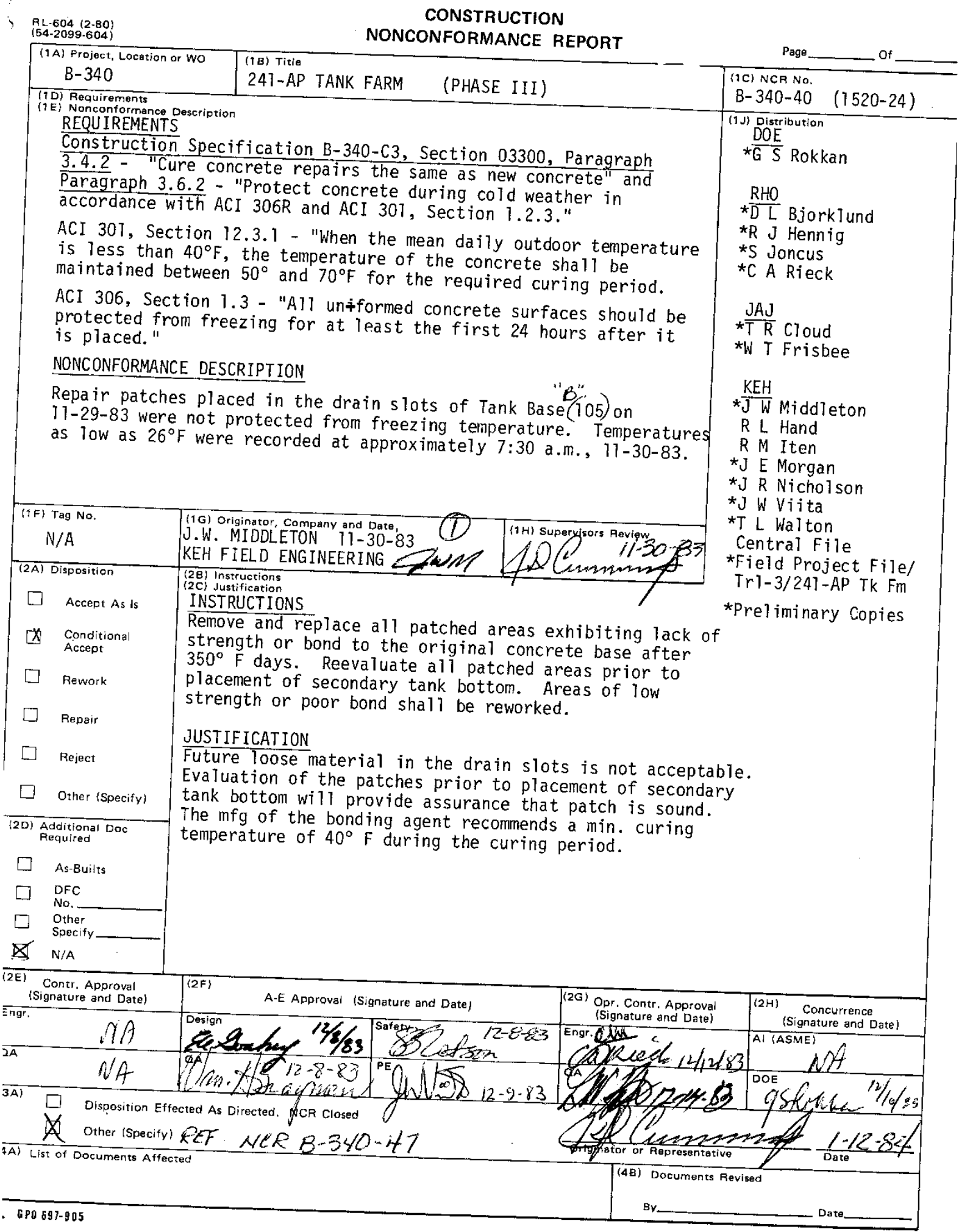


RPP-RPT-55983, Rev. 0

\section{App. Figure B-33. Nonconformance Report B-340-42}

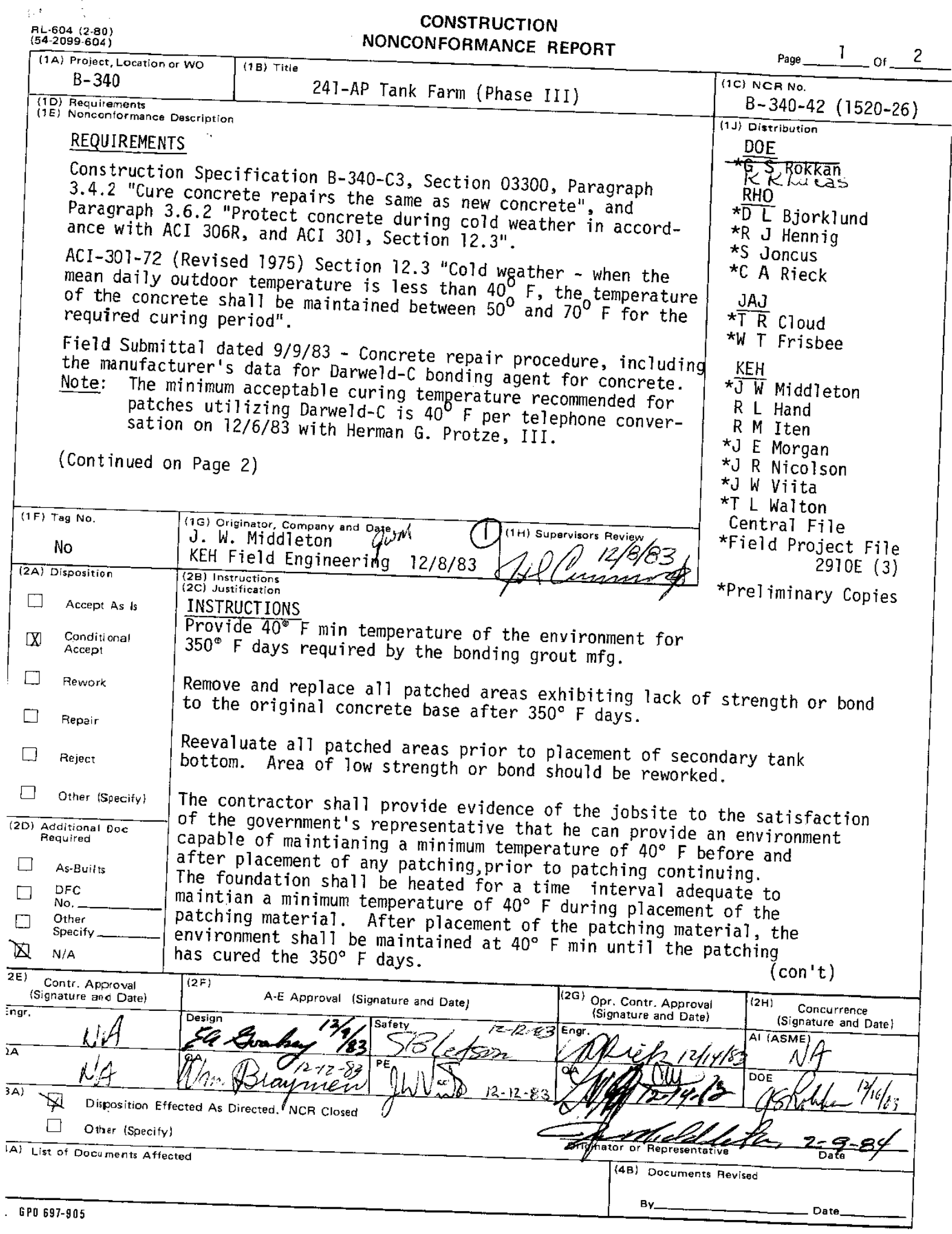


RPP-RPT-55983, Rev. 0

Page 2 of 2

NCR \#B-340-42

241-AP Tank Farm (Phase III)

\section{NONCONFORMANCE DESCRIPTION}

Repair patches placed on tankbase 101, 104 and 102, have not been adequately protected from cold weather.

Repair patches on tankbase 101 placed on $11 / 29 / 83$ and $12 / 2 / 83$ had recorded overnight and morning temperatures ranging from $37^{8} \mathrm{~F}$ to $36^{\circ} \mathrm{F}$ on five (5)
consecutive days after placement.

Repair patches on tankbase 104 placed on $12 / 2 / 83$ ranged from $33^{\circ} \mathrm{F}$ to $36^{\circ} \mathrm{F}$ for 3 consecutive days after placement.

Repair patches placed on tankbase 102 on $12 / 7 / 83$ ranged from $36^{\circ} \mathrm{F}$ to $37^{\circ} \mathrm{F}$ the first morning after placement.

JUSTIFICATION

Future loose material from the patching is not acceptable. Evaluation of the patches prior to placement of secondary tank bottom will provide assurance that patch is sound. Acceptance of the patching requires the contractor to comply with the manufacturers instructions for the use and application of the bonding grout. 
RPP-RPT-55983, Rev. 0

App. Figure B-34. Nonconformance Report B-340-43

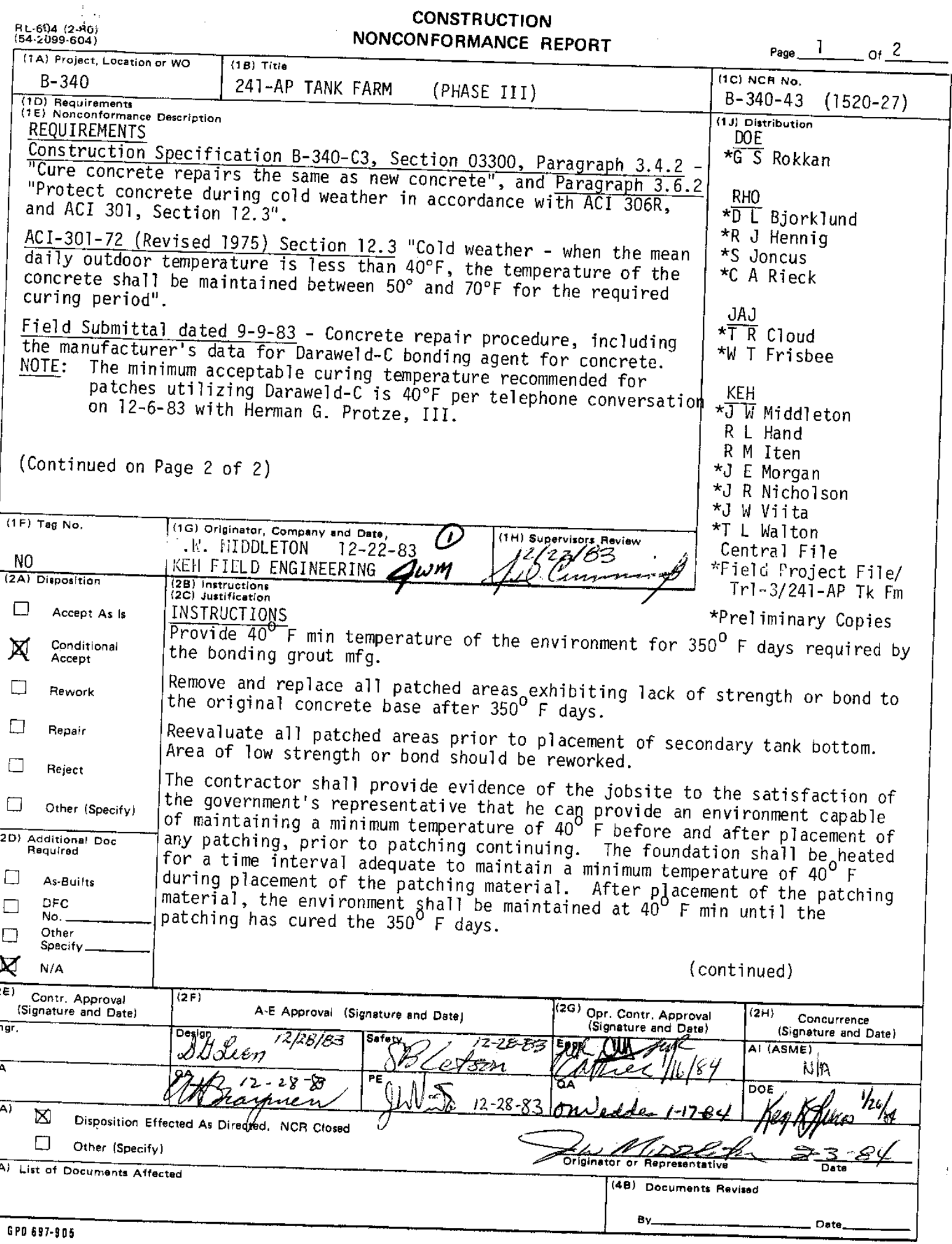


RPP-RPT-55983, Rev. 0

$B-340-43(1520-27)$

Page 2 of 2

NONCONFORMANCE DESCRIPTION

Repair patches placed on 12-19-83 at Tank Base "( 02 )have not been adequately protected from cold weather.

Morning temperatures on 12-22-83 revealed patch temperatures ranging from $28^{\circ} \mathrm{F}$ to $34^{\circ} \mathrm{F}$. Ice formations were apparent on several patches. The ambient overnight low within the heated shel ter was $25^{\circ} \mathrm{F}$.

2C. JUSTIFICATION

Future loose material from the patching is not acceptable. Evaluation of the patches prior to placement of secondary tank bottom will provide assurance that patch is sound. Acceptance of the patching requires the contractor to comply with the manufacturers instructions for the use and application of the bonding grout. 


\section{App. Figure B-35. Nonconformance Report B-340-46}

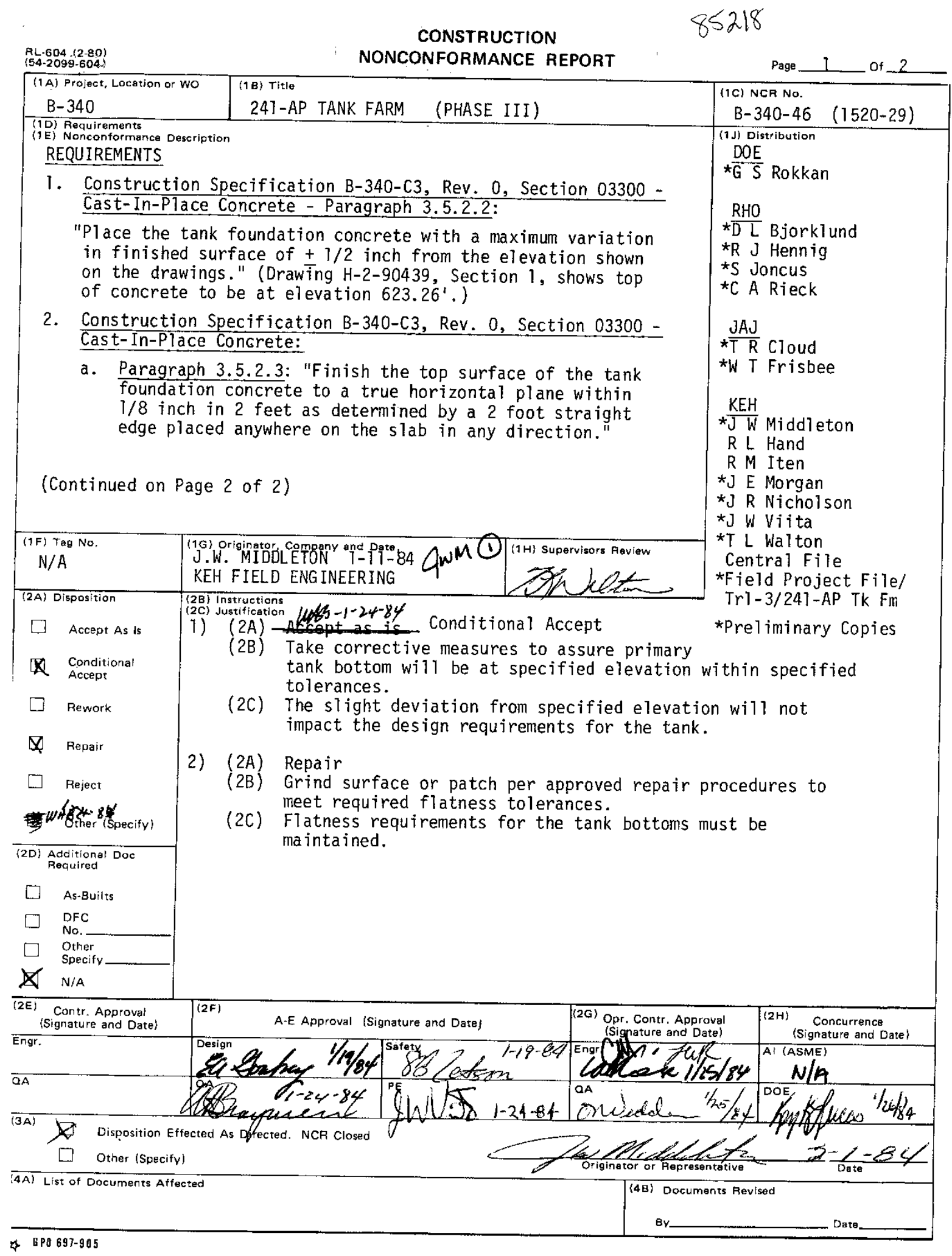


RPP-RPT-55983, Rev. 0

NCR B-340-46

Page 2 of 2

REQUIREMENTS (Continued)

2. Construction Specification B-340-C3, Rev. 0, Section $03300-$ Cast-In-Place Concrete:

b. Paragraph 3.5.2.4: "Finish the top of tank foundation concrete to a true horizontal plane within $1 / 4$ inch in 10 feet as determined by a 10 foot straight edge placed anywhere on the slab in any direction."

NONCONFORMANCE DESCRIPTION

1. At Tank Foundation 101 there are 11 locations on the top of the concrete foundation that are out of tolerance by 0.01 of a foot (1/8 inch). (See attached survey data report)

2. At Tank Foundation 101 there are 20 areas that do not meet the required flatness tolerances. These areas exceed ejther or both the $1 / 4$ inch in 10 foot or $1 / 8$ inch in 2 foot flatness tolerance. (See attached flatness check report.) 
RPP-RPT-55983, Rev. 0

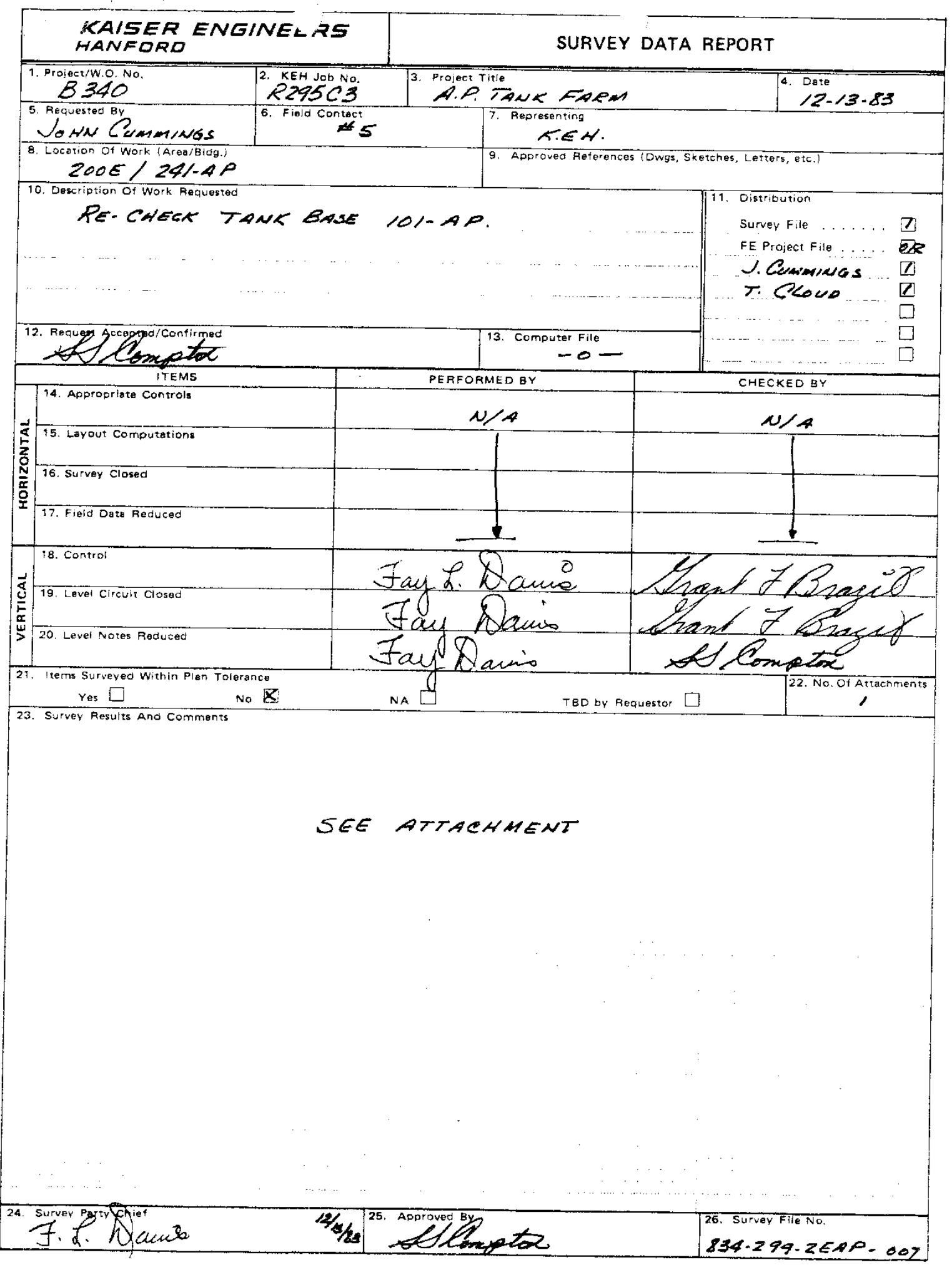


RPP-RPT-55983, Rev. 0

App. Figure B-36. Nonconformance Report B-340-47

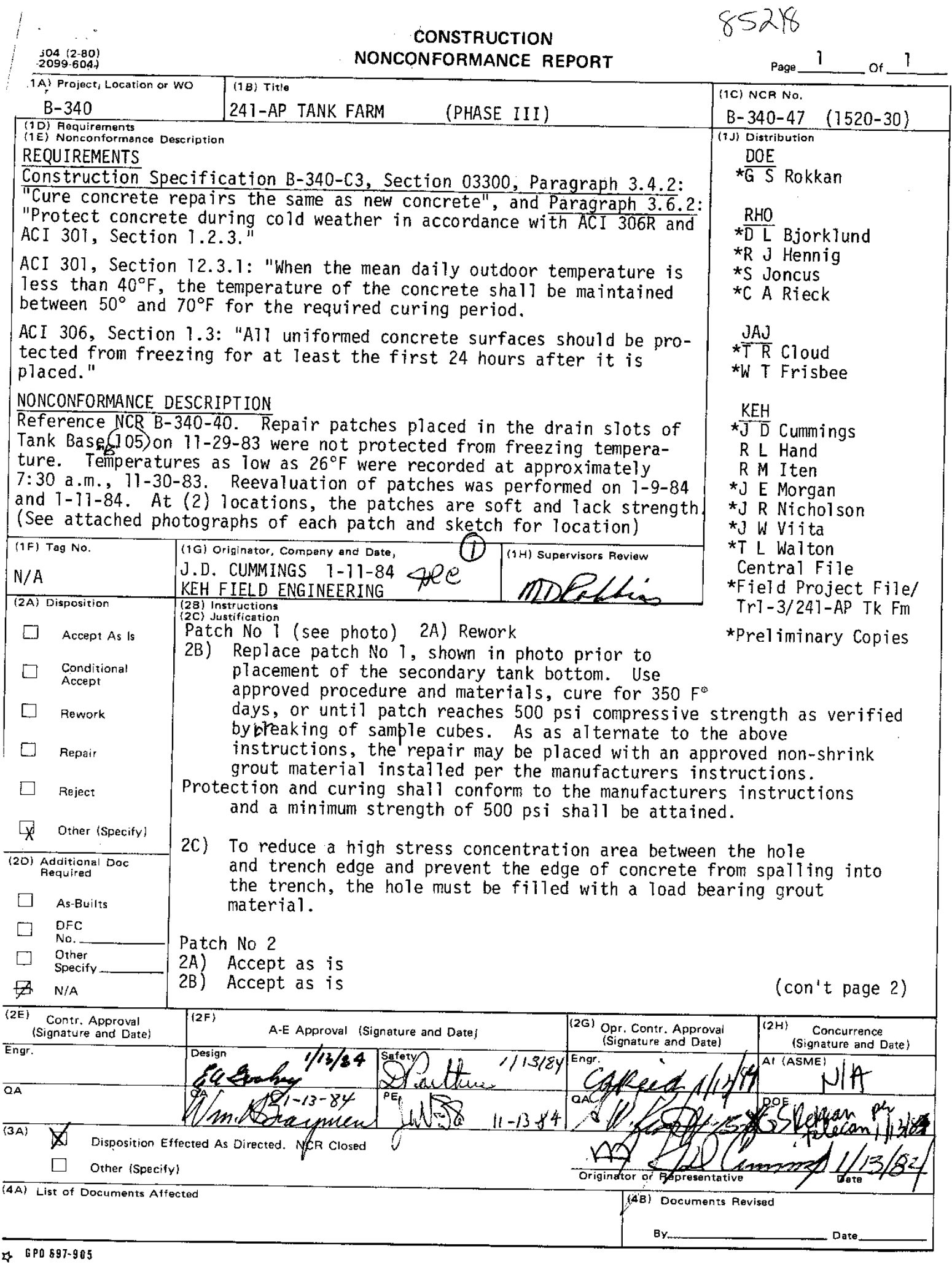


RPP-RPT-55983, Rev. 0

NCR-B-340-47

Page 2

2C) The patch in the immediate area occupies about $35 \%$ of the surface area. This would not block the trench if it became detached. 
RPP-RPT-55983, Rev. 0

NCR B-340-47

ATTACHMENT

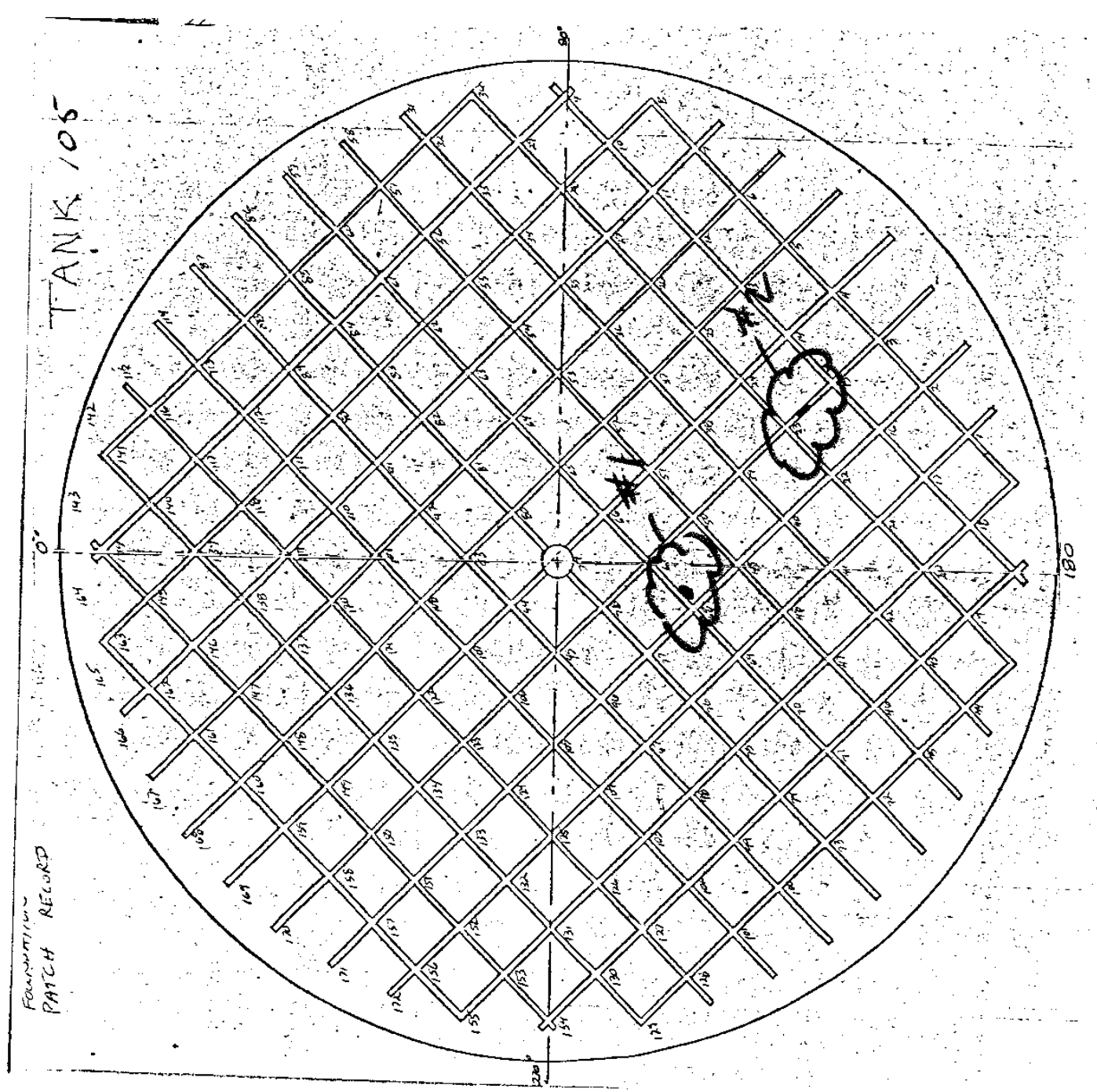


RPP-RPT-55983, Rev. 0

NCR B $340-47$

ATTACHMENT
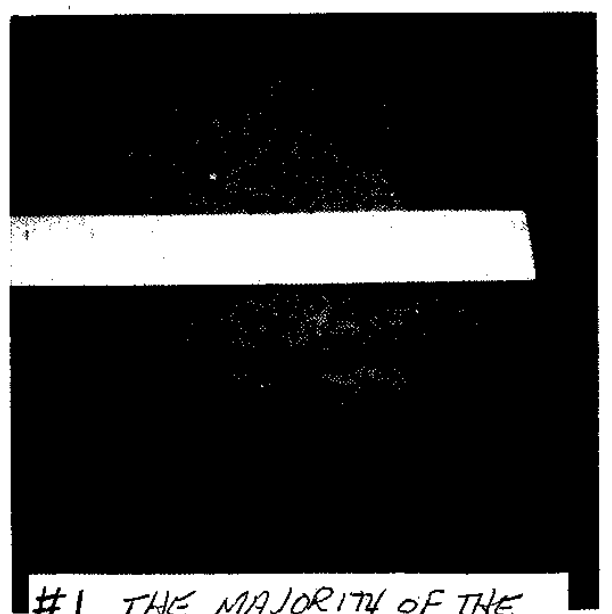

\#I THE MAJORITH OF THE

PATCH MATER ALL HAS BEEN

RONOVED. STANDING WATER

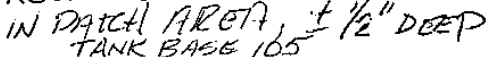

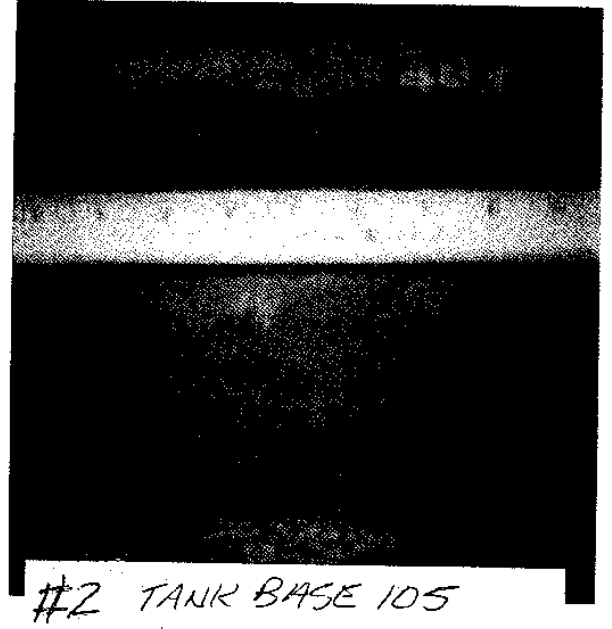

FATCH IN BOTTOM OF SLOT.

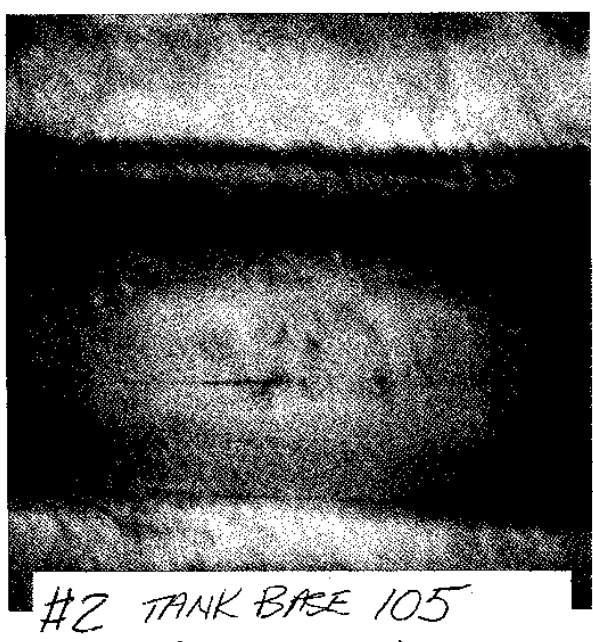

PATCAIIN BOTTOMI OF SLOT 
RPP-RPT-55983, Rev. 0

App. Figure B-37. Nonconformance Report B-340-49

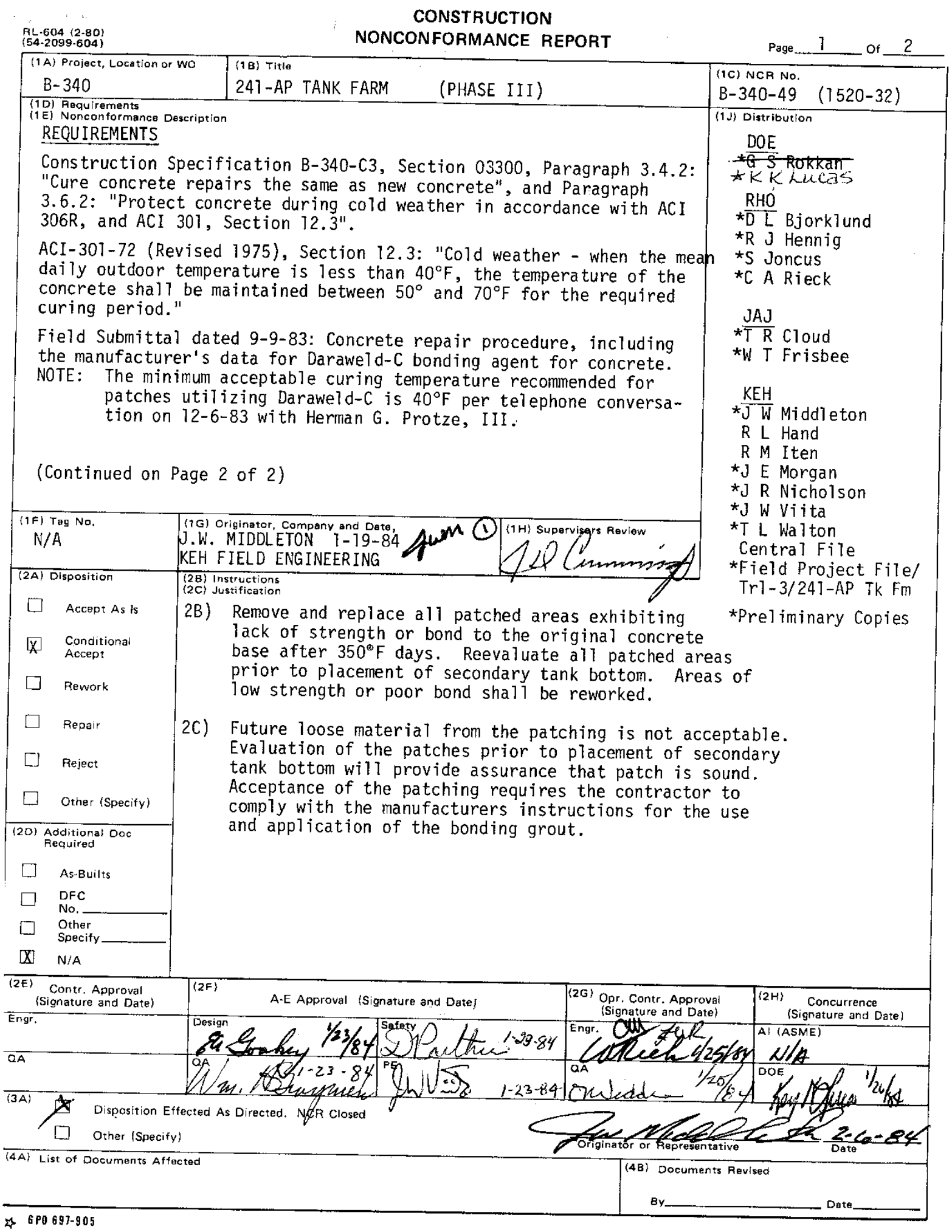


RPP-RPT-55983, Rev. 0

NCR B-340-49

Page 2 of 2

NONCONFORMANCE DESCRIPTION

Repair patches placed on Tank Base 1 (102) on 1-13-84, 1-16-84 and 1-17-84 have not been adequately protected from cold weather.

On 1-19-84, at approximately 9:30 a.m., recorded patch temperatures ranged from $33^{\circ} \mathrm{F}$ to $39^{\circ} \mathrm{F}$.

See attached sketch for patch Tocations.

NOTE: Morning temperatures were again below $40^{\circ} \mathrm{F}$ for these repaired areas on 1/20/84 per JD Cummings. 
RPP-RPT-55983, Rev. 0

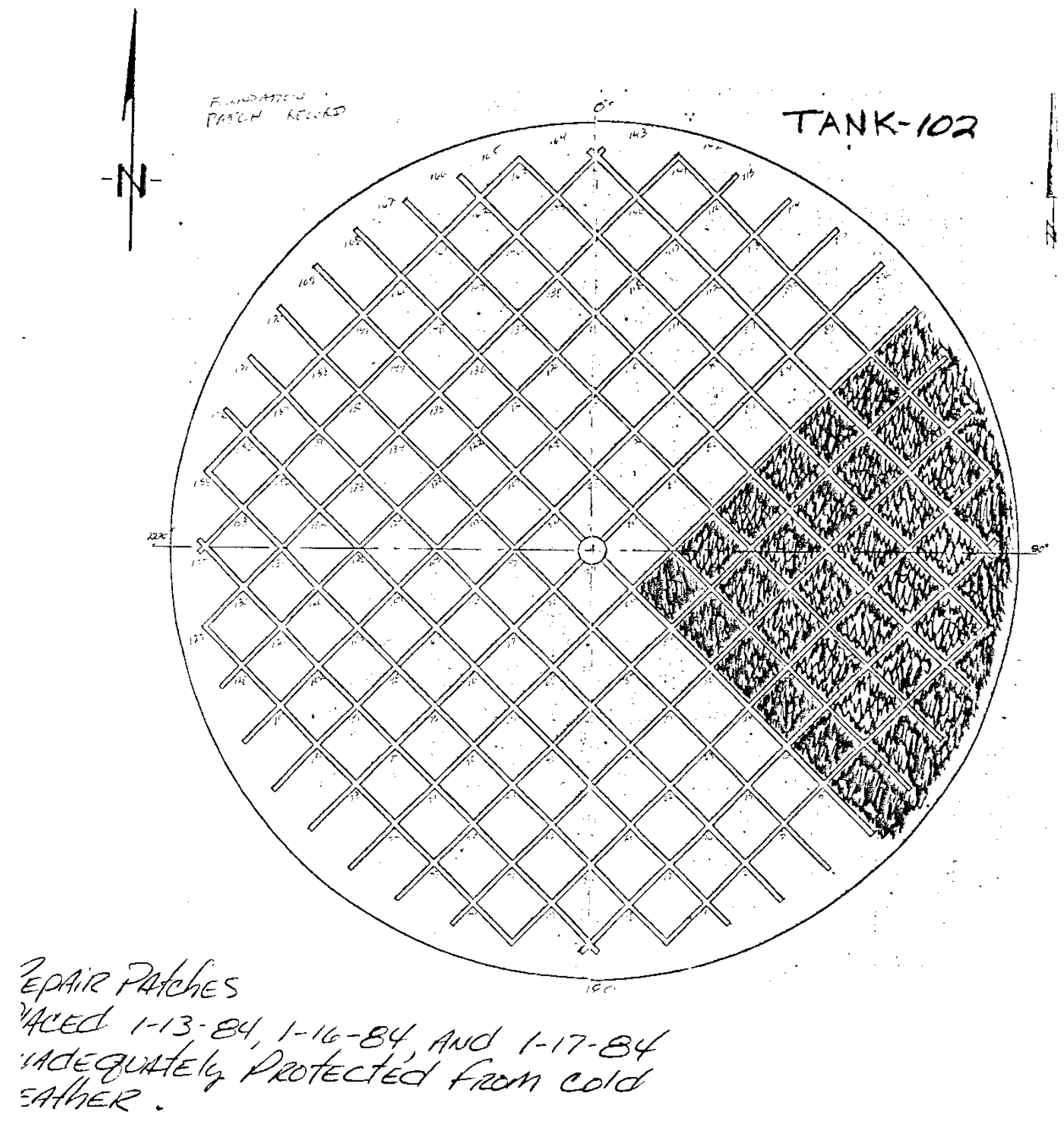


RPP-RPT-55983, Rev. 0

\section{App. Figure B-38. Nonconformance Report B-340-51}

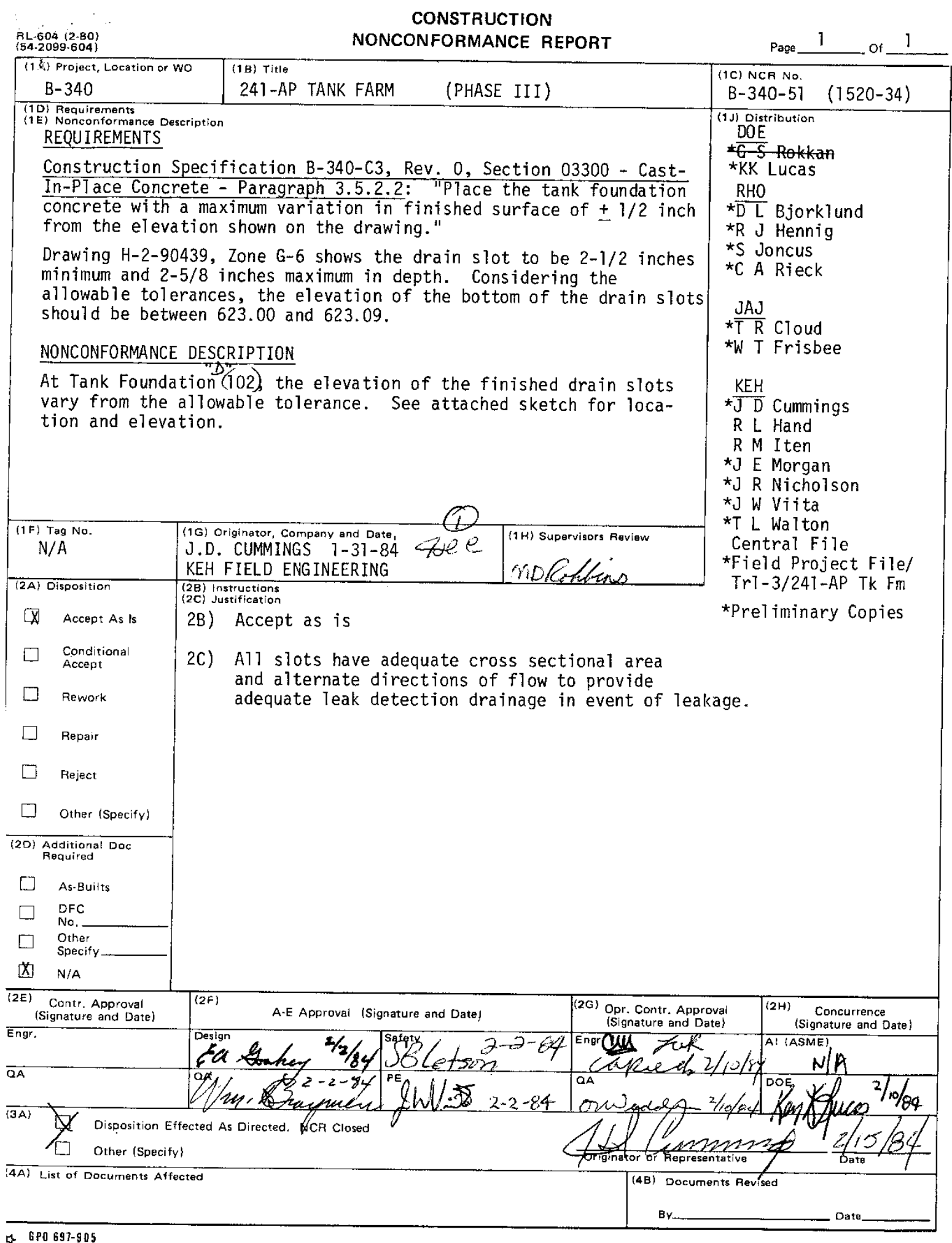


RPP-RPT-55983, Rev. 0

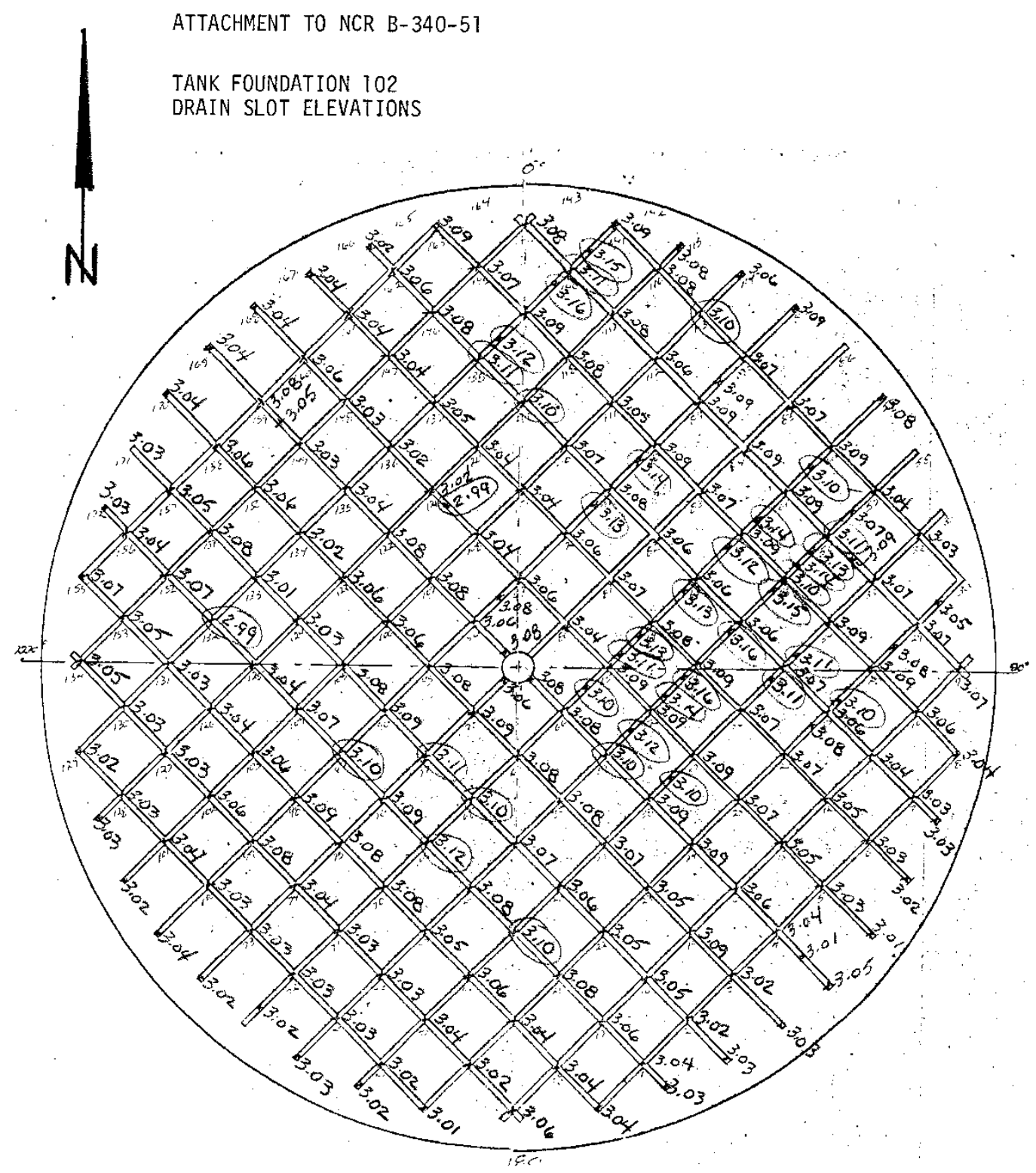

NOTE: \#1. Add 620.00 to a 11 readings shown.

\#2. Out of tolerance elevations are circled.

\#3. Elevation data is taken from Survey Data Reports of 1-10-84, 1-11-84 and 1-27-84. 
RPP-RPT-55983, Rev. 0

App. Figure B-39. Nonconformance Report B-340-53

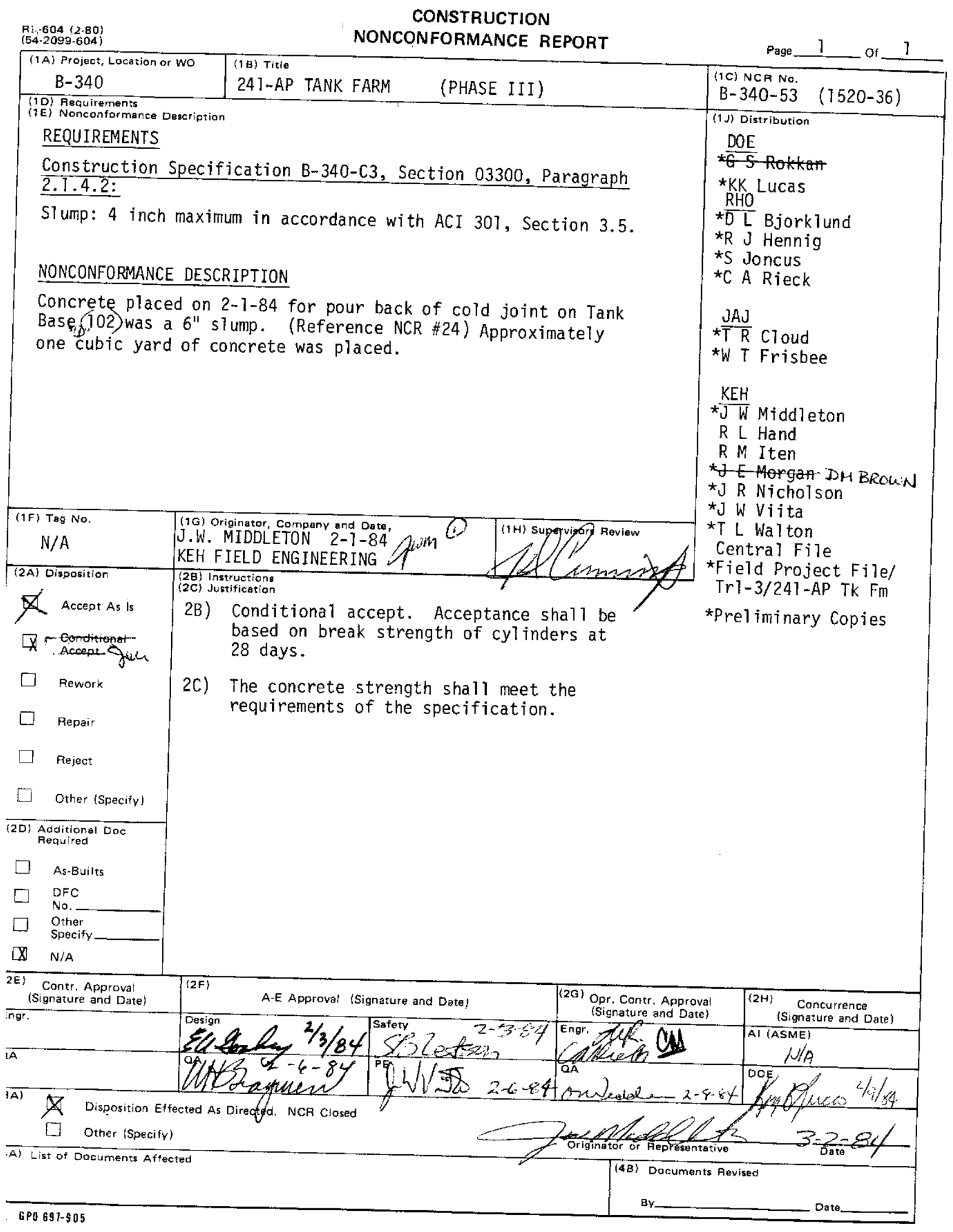


RPP-RPT-55983, Rev. 0

App. Figure B-40. Nonconformance Report B-340-101

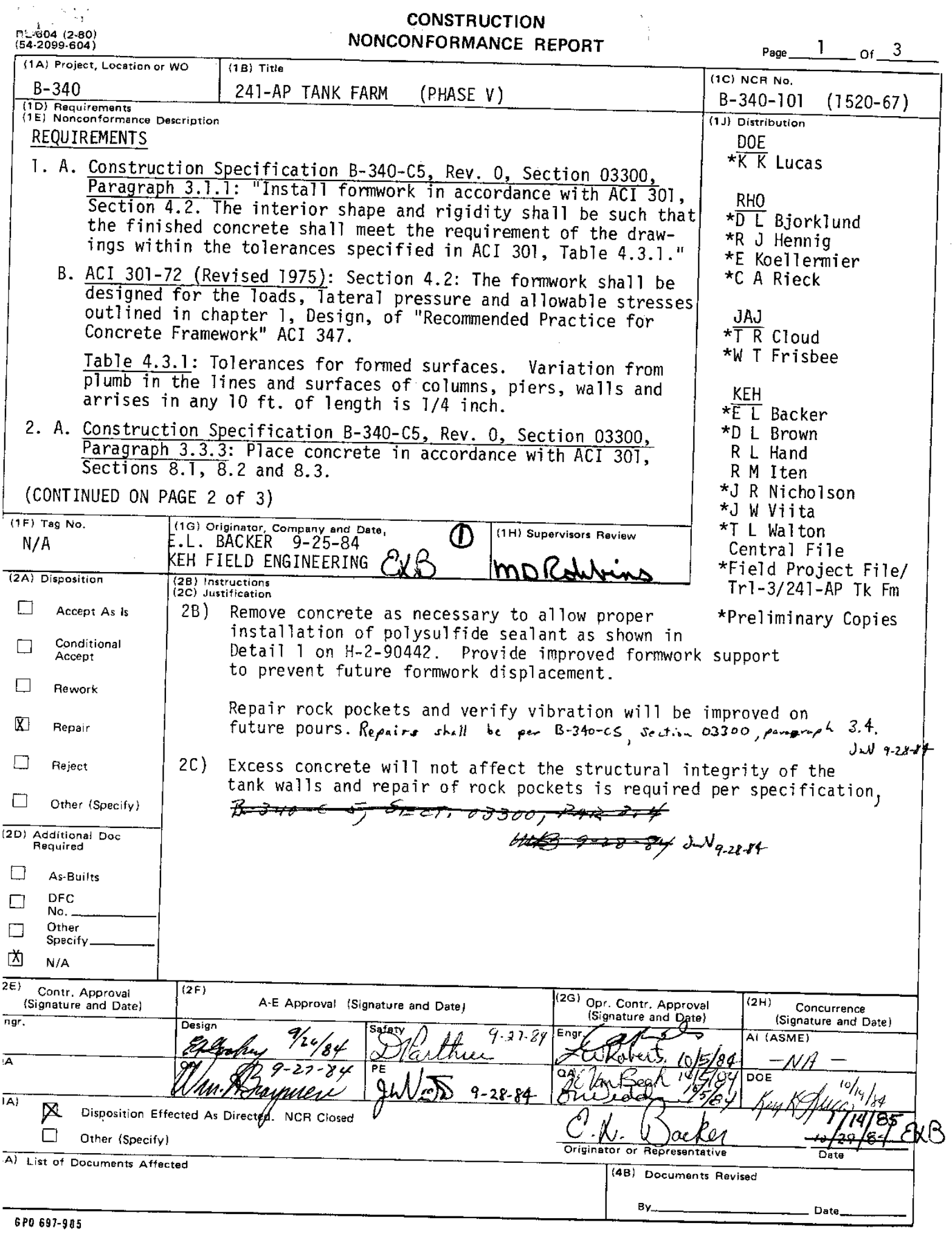


RPP-RPT-55983, Rev. 0

NCR B-340-10] (1520-67)

Page 2 of 3

REQUIREMENTS (Continued)

2. B. ACI 301-72 (Revised 1975): Section 8.3.4 - Consolidation: Al 1 concrete shall be consolidated by vibration, spading, rodding or forking so that the concrete is thoroughly worked around the reinforcement, around embedded $i$ tems, and into corners of forms, eliminating aliair or stone pockets which may cause honeycombing, pitting or planes of weakness.

\section{NONCONFORMANCE DESCRIPTION}

Tank 108: During placement of concrete, forms gave way (see Attached Sketch \#1). Also, vibration was not performed adequately, causing some rock pockets on the surface approximately 4 inches deep. 
RPP-RPT-55983, Rev. 0

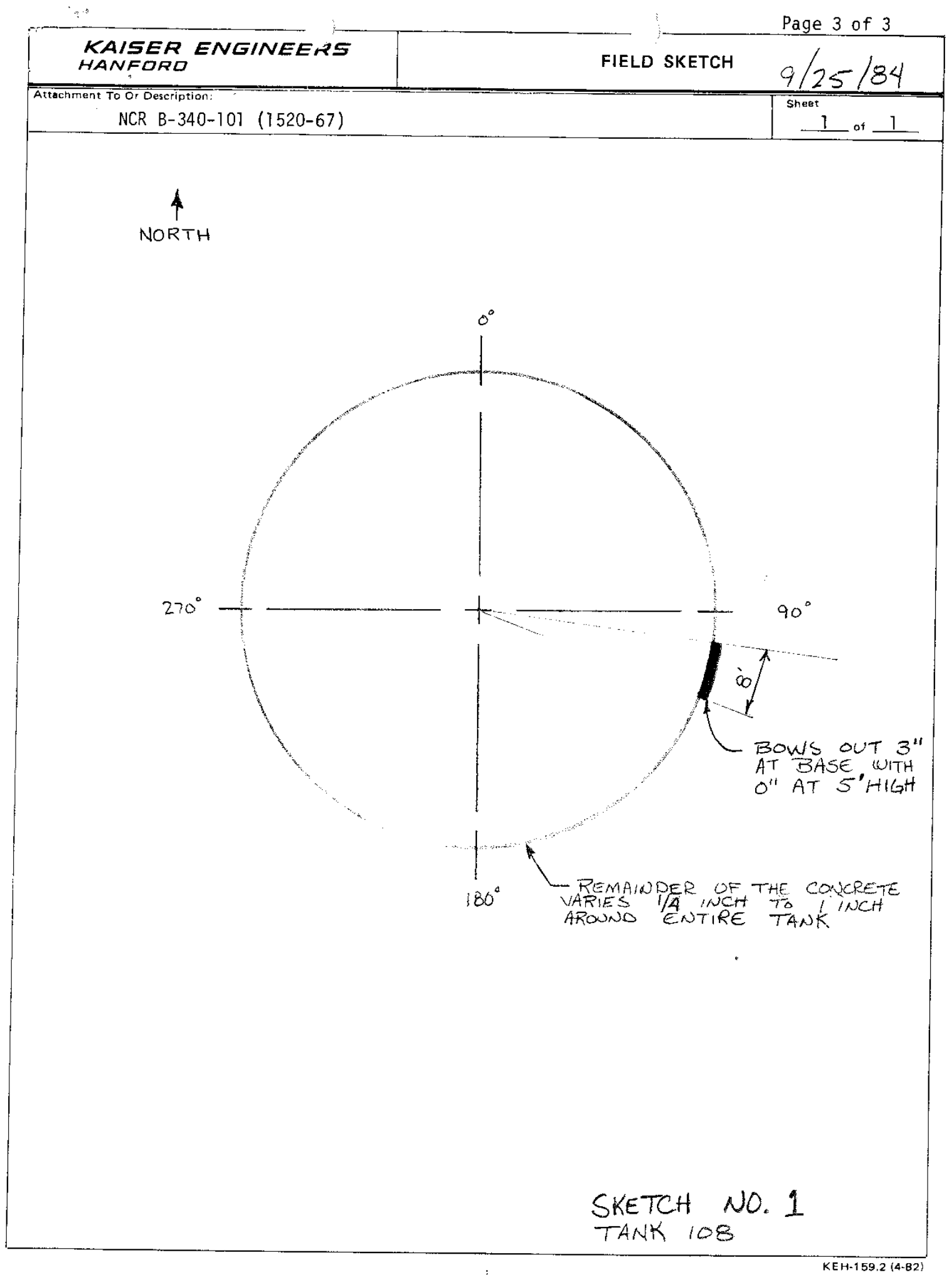


RPP-RPT-55983, Rev. 0

App. Figure B-41. Nonconformance Report B-340-107

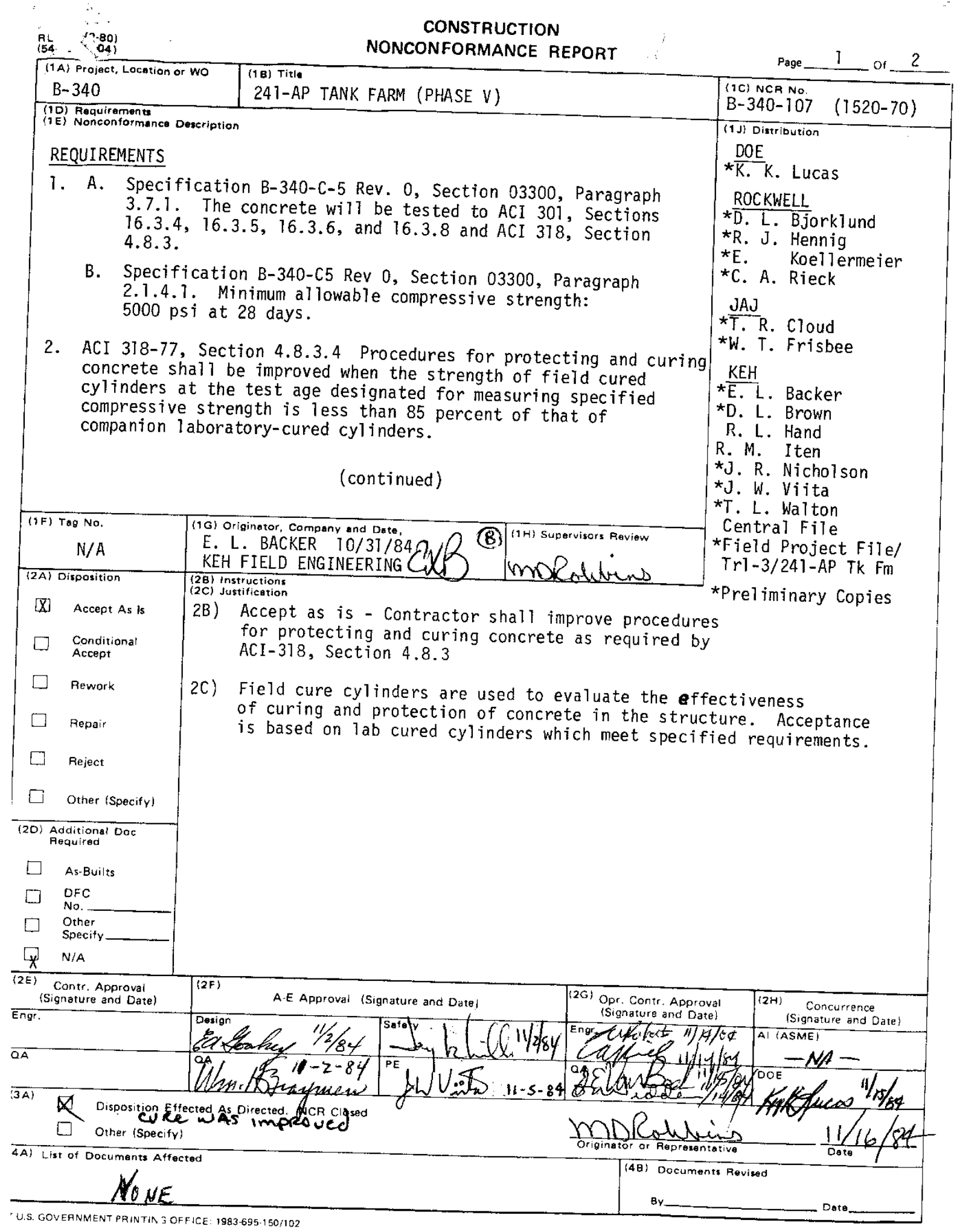


RPP-RPT-55983, Rev. 0

\begin{tabular}{|c|c|c|c|}
\hline \multicolumn{4}{|l|}{$\begin{array}{l}\text { NCR B-340-107 } \\
\text { Page } 2 \text { of } 2 \\
\text { NONCONFORMANCE } \\
\text { DESCRIPTION }\end{array}$} \\
\hline \multicolumn{2}{|c|}{$\begin{array}{l}\text { Tank } 107 \text { lower shell concrete breaks at } 28 \text { days: } \\
\text { make } 5000 \text { psi or } 85 \% \text { of } 1 \text { ab cured cylinders. }\end{array}$} & \multicolumn{2}{|c|}{ Field cured cylinders failed to } \\
\hline Test No. & Cylinder No. & PSI a 28 & \\
\hline 1 & $\begin{array}{l}3178-3 \\
3178-4 \\
3178-5 \quad(F C) \\
3178-6(F C)\end{array}$ & $\begin{array}{l}5980 \\
5940 \\
4920 \\
4830\end{array}$ & $\begin{array}{l}0.85(5980)=5083 \\
0.85(5940)=5049\end{array}$ \\
\hline 2 & $\begin{array}{l}3178-9 \\
3178-10 \\
3178-11 \quad(F C) \\
3178-12 \quad(F C)\end{array}$ & $\begin{array}{l}5910 \\
5960 \\
4600 \\
4650\end{array}$ & $\begin{array}{l}0.85(5910)=5024 \\
0.85(5960)=5066\end{array}$ \\
\hline 3 & $\begin{array}{l}3178-15 \\
3178-16 \\
3178-17 \text { (FC) } \\
3178-18 \text { (FC) }\end{array}$ & $\begin{array}{l}6230 \\
6170 \\
4850 \\
4780\end{array}$ & $\begin{array}{l}0.85(6230)=5296 \\
0.85(6170)=5245\end{array}$ \\
\hline
\end{tabular}

$E L B / 1 v$ 
RPP-RPT-55983, Rev. 0

App. Figure B-42. Nonconformance Report B-340-108

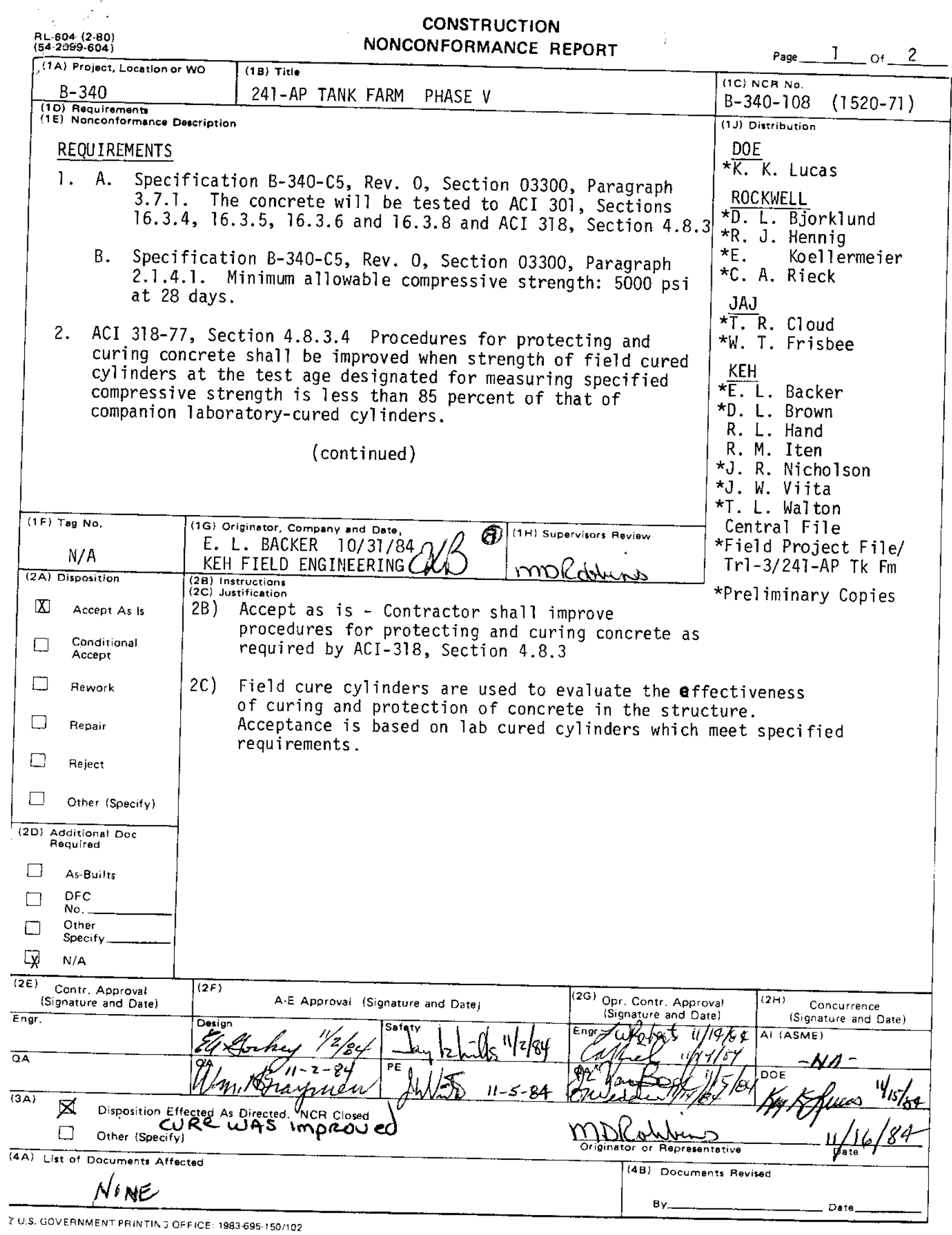


RPP-RPT-55983, Rev. 0

NCR B-340-108 (1520-71)

Page 2 of 2

NONCONFORMANCE

DESCRIPTION

Tank 108 upper shell concrete breaks at 28 days: Field cured cylinders failed to make 5000 psi or $85 \%$ of Jab cured cylinders.

Test No.

1

2

3
Cyl inder No.

$3179-3$

$3179-4$

$3179-5(\mathrm{FC})$

$3179-6$ (FC)

$3179-9$

$3179-10$

$3179-11$ (FC)

$3179-12$ (FC)

$3179-15$

3179-16

$3179-17$ (FC)

3179-18 (FC)
PSI 28 days

5780

5870

4930

4860

5960

5930

4700

4700

5860

5730

4900

4900
$.85(5780)=4913$

$.85(5870)=4990$

$.85(5960)=5066$

$.85(5930)=5041$

$.85(5860)=4981$

$.85(5730)=4871$

$E L B /$ IV 
RPP-RPT-55983, Rev. 0

App. Figure B-43. Nonconformance Report B-340-109

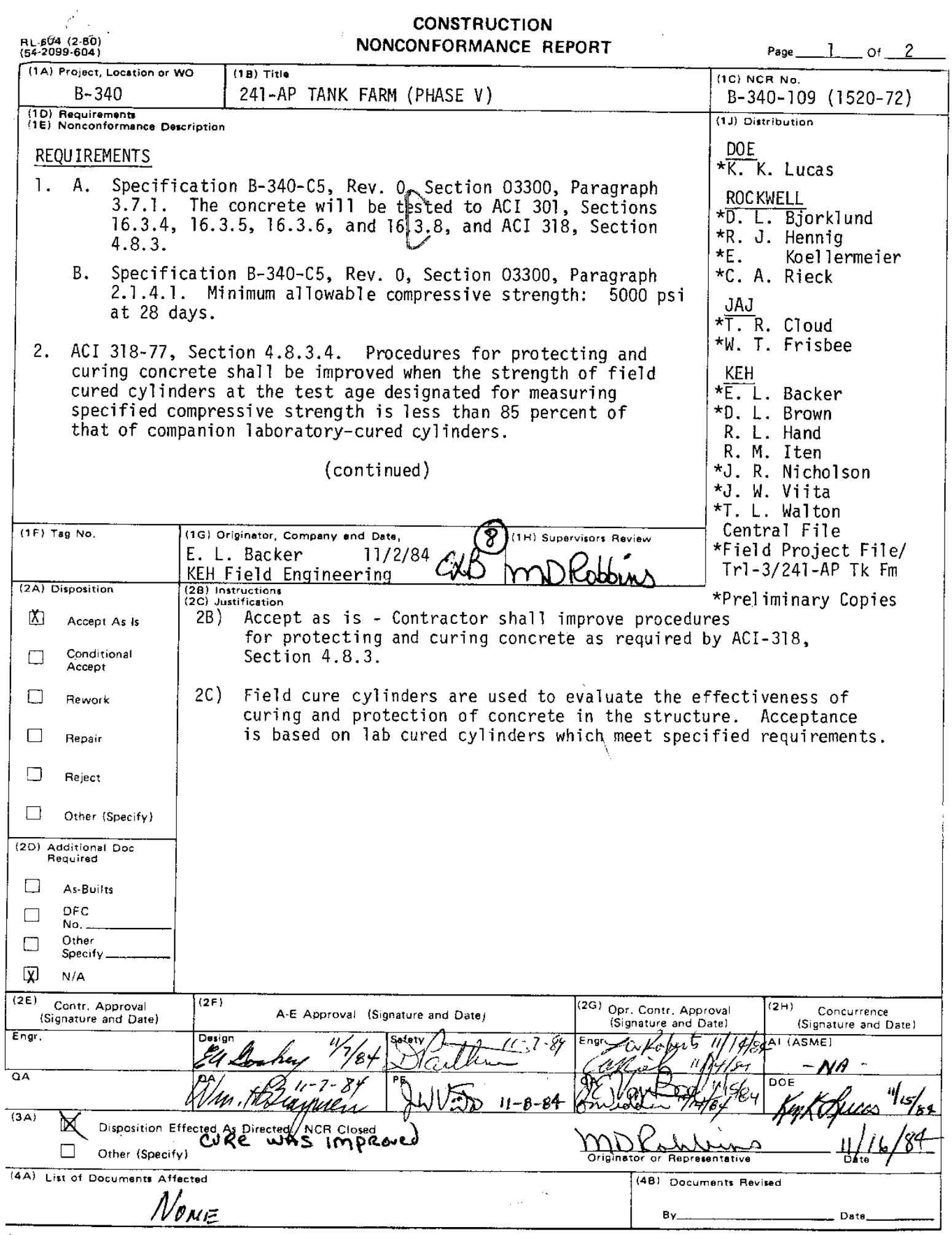

5. U.S. GOVEANMENT PAINTIN ; OFFICE. 1983-695-150/102 
RPP-RPT-55983, Rev. 0

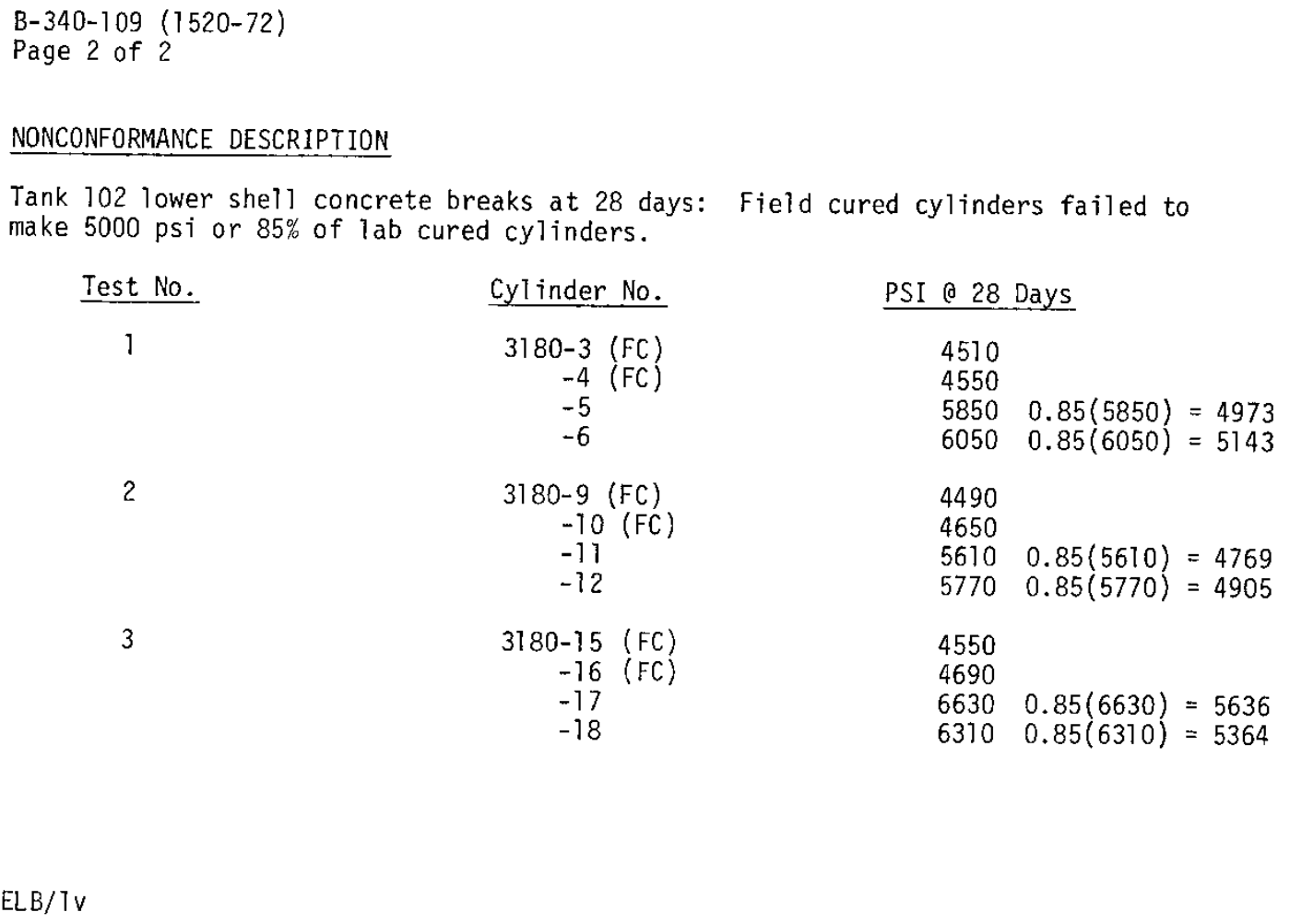


RPP-RPT-55983, Rev. 0

\section{App. Figure B-44. Nonconformance Report B-340-111}

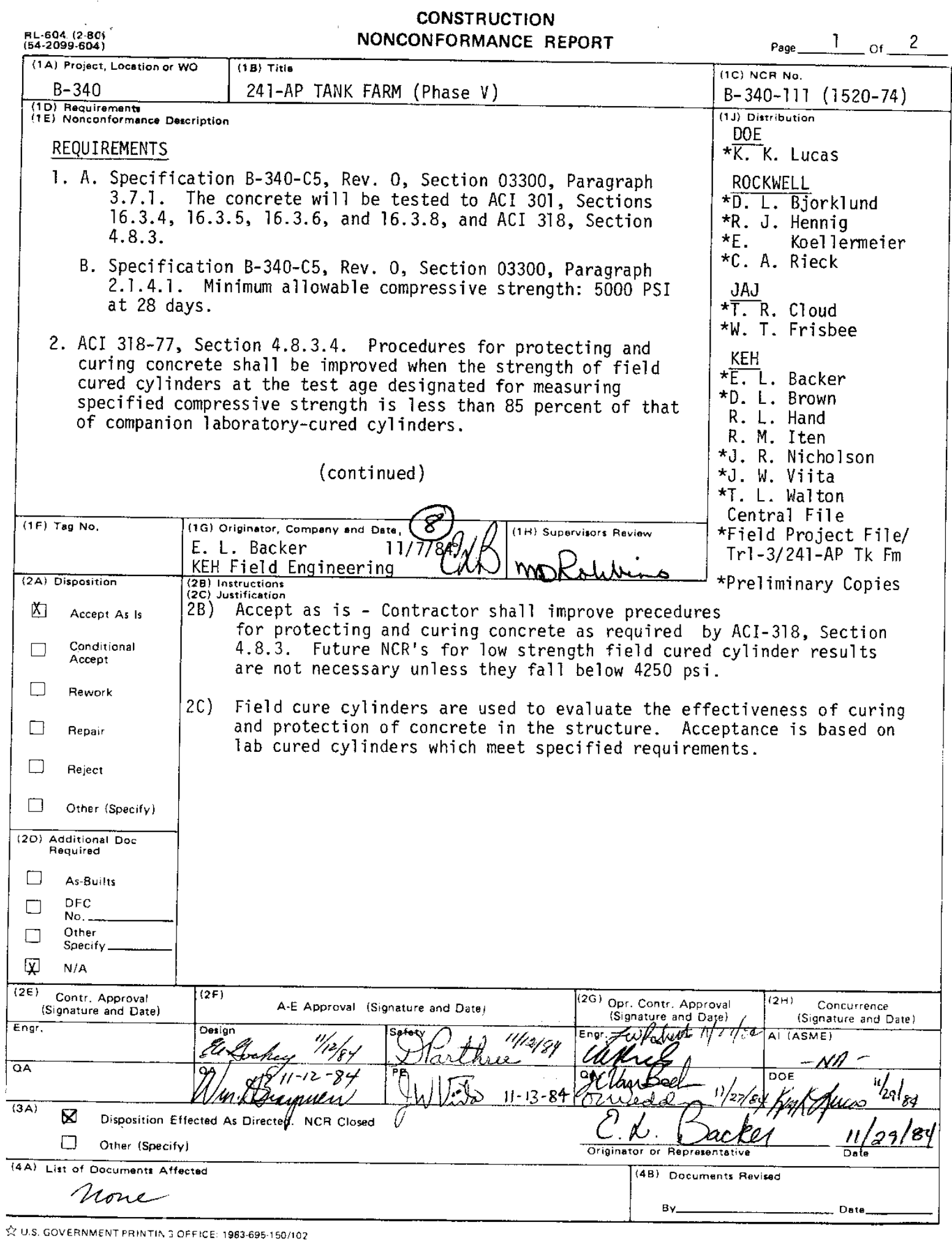


RPP-RPT-55983, Rev. 0

NCR B-340-111 (1520-74)

Page 2 of 2

NONCONFORMANCE DESCRIPTION

Tank 107 upper shell concrete breaks at 28 days: field cured cylinders failed to make 5000 PSI or $85 \%$ of 1 ab cured cylinders.

Test No.

1

2

3
Cylinder No.

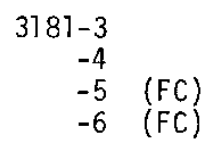

$3181-9$

$-10$

$-11(\mathrm{FC})$

$-12(\mathrm{FC})$

$3789-15$

$-16$

$-17(F C)$

-18 (FC)
PSI 28 Days

$\begin{array}{ll}5570 & 0.85(5570)=4735 \\ 5660 & 0.85(5660)=4811 \\ 4320 & \\ 4210 & \\ 5590 & 0.85(5590)=4752 \\ 5660 & 0.85(5660)=4811 \\ 4420 & \\ 4320 & \\ 5640 & 0.85(5640)=4794 \\ 5570 & 0.85(5570)=4735 \\ 3960 & \end{array}$

$E L B / 1 V$ 
RPP-RPT-55983, Rev. 0

\section{App. Figure B-45. Nonconformance Report B-340-114}

RL-604 (2-80)

CONSTRUCTION

(1 A) Project, NONCONFORMANCE REPORT

\begin{tabular}{|c|c|c|}
\hline \multicolumn{2}{|c|}{ (1A) Project, Locstion or wo } & $\begin{array}{l}\text { (18) Title } \\
\text { 241-AP TANK FARM (PHASE V) }\end{array}$ \\
\hline \multicolumn{3}{|c|}{\begin{tabular}{l|l} 
B-340 & 241-AP TANK FARM (PHASE V) \\
(1D) Requiramentz \\
(iE) Nonconformence Description
\end{tabular}} \\
\hline \multicolumn{3}{|c|}{ REQU IREMENTS } \\
\hline 1. A. & $\begin{array}{l}\text { Specifica } \\
3.7 .7 . \text { T } \\
16.3 .4,1 \\
4.8 .3\end{array}$ & $\begin{array}{l}\text { on B-340-C5, Rev. 0, Section } 03300 \text {, Paragraph } \\
\text { concrete wil1 be tested to ACI } 301 \text {, Sections } \\
3.5,16.3 .6 \text {, and } 16.3 .8 \text {, and ACI } 318 \text {, Section }\end{array}$ \\
\hline B. & $\begin{array}{l}\text { Specifica } \\
2.1 .4 .1 \\
\text { psi at } 28\end{array}$ & $\begin{array}{l}\text { B-340-C5, Rev. 0, Section } 03300 \text {, Paragraph } \\
\text { imum al lowable compressive strength: } 5000 \\
\text {. }\end{array}$ \\
\hline
\end{tabular}

2. ACI 318-77, Section 4.8.3.4. Procedures for protecting and curing concrete shall be improved when the strength of field cured cylinders at the test age designated for measuring specified compressive strength is Jess than 85 percent of that of companion laboratory-cured cylinders.

(continued)

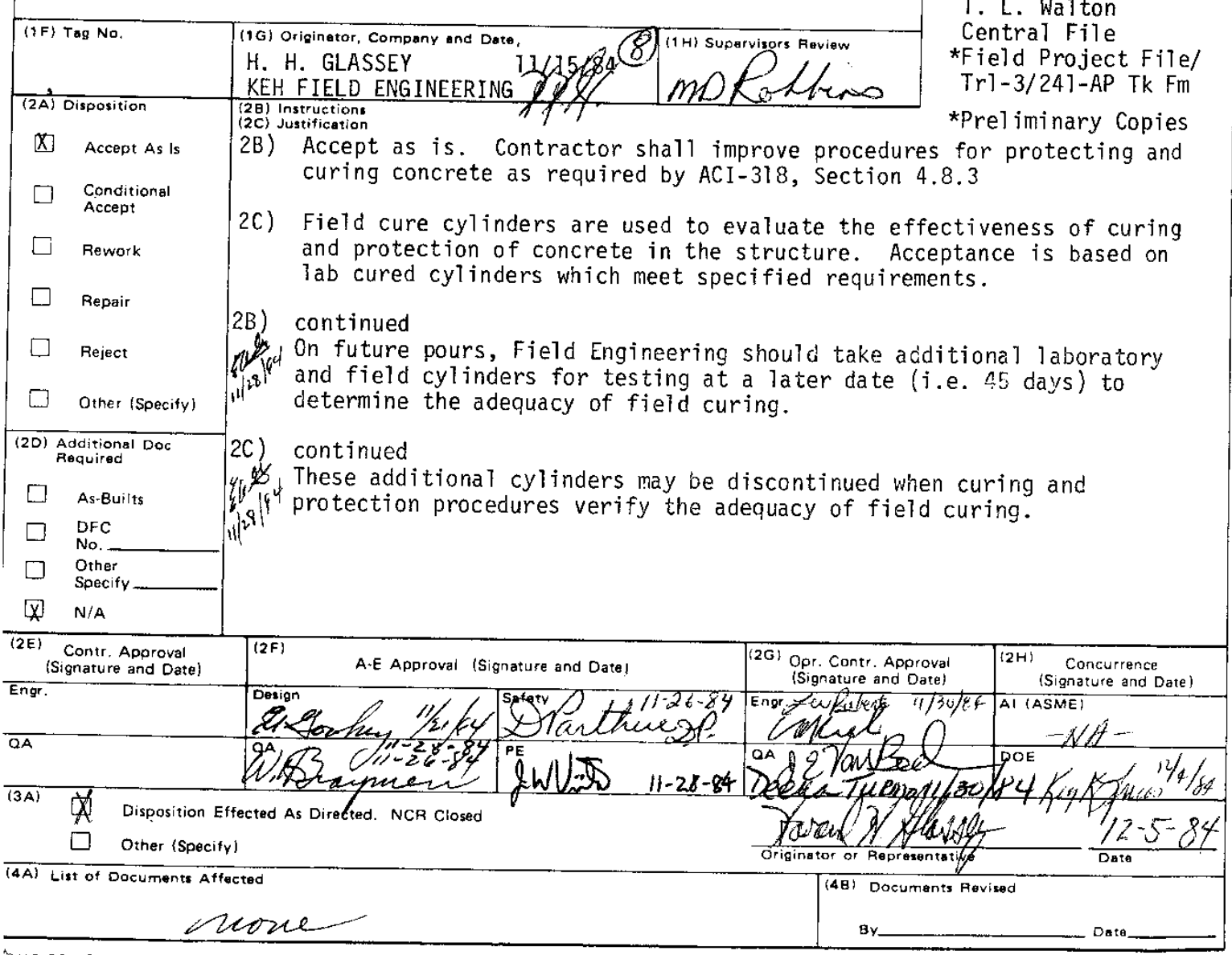

3 U.S. GOVERNMENT PRINTIN ב OFFICE: 1983-695.150/102 
RPP-RPT-55983, Rev. 0

NCR B-340-114 (1520-76)

Page 2 of 2

\section{NONCONFORMANCE DESCRIPTION}

Tank 101 upper shell concrete breaks at 28 days: field cured cylinders failed to make 5000 psi or $85 \%$ of 1 aboratory-cured cylinders.

Test No.

1.

2.

3.

$$
\begin{aligned}
& \text { Cylinder No. } \\
& 3184-3 \\
& 3184-4 \\
& 3184-5 \text { (FC) } \\
& 3184-6 \text { (FC) } \\
& 3184-9 \\
& 3184-10 \\
& 3184-11 \text { (FC) } \\
& 3184-12 \text { (FC) }
\end{aligned}
$$

$3184-15$

$3184-16$

$3184-17$ (FC)

3184-18 (FC)
PSI at 28 Days

$\begin{array}{ll}5700 & 0.85(5700)=4845 \\ 5840 & 0.85(5840)=4964 \\ 4180 & \\ 4270 & \\ 5890 & 0.85(5890)=5007 \\ 5820 & 0.85(5820)=4947 \\ 4160 & \\ 4120 & \\ 6050 & 0.85(6050)=5143 \\ 5900 & 0.85(5900)=5015 \\ 4070 & \end{array}$

$H H G / I V$ 
RPP-RPT-55983, Rev. 0

\section{App. Figure B-46. Nonconformance Report B-340-116}

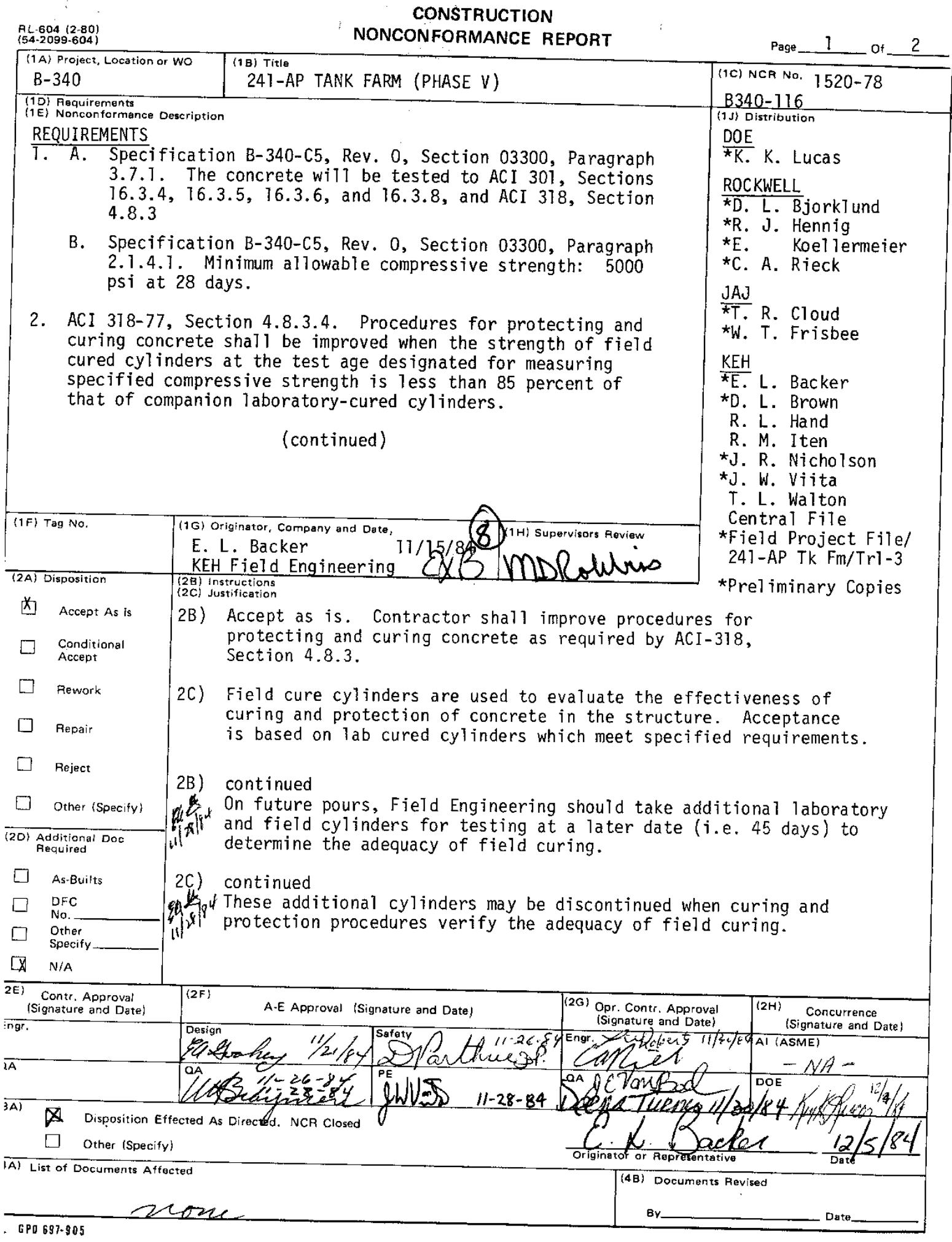


RPP-RPT-55983, Rev. 0

NCR B-340-116 (1520-78)

Page 2 of 2

NONCONFORMANCE DESCR IPTION

Tank 102 upper shell concrete breaks at 28 days: field cured cylinders fajled to make 5000 psi or $85 \%$ of 1 aboratory-cured cylinders.

Test No.

1.

2.

3.
Cylinder No.

3183-3

$-4$

$-5(F C)$

$-6(F C)$

$3183-9$

$-10$

$-11(F C)$

$-12(F C)$

Field cured cylinders acceptable
PSI 028 Days

$59400.85(5940)=5049$

$59900.85(5990)=5092$

3800

3820

$67300.85(6730)=5720$

$68400.85(6840)=5874$

4190

4190

$E L B / T V$

B-109 
RPP-RPT-55983, Rev. 0

App. Figure B-47. Nonconformance Report B-340-117

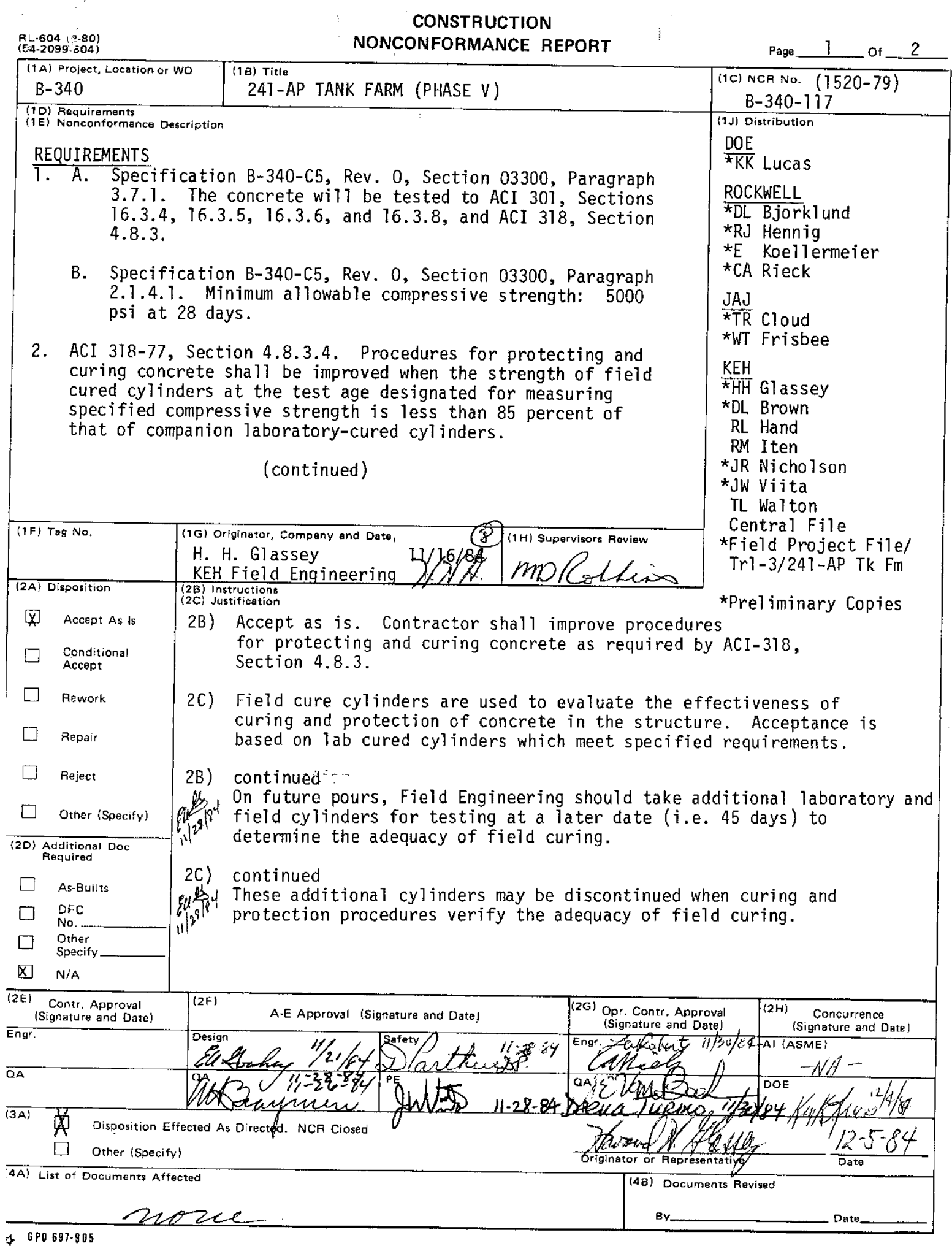


RPP-RPT-55983, Rev. 0

NCR B-340-117 (1520-79)

Page 2 of 2

NONCONFORMANCE DESCRIPTION

Tank \#106 lower shell concrete breaks at 28 days: field cured cylinders

failed to make 5000 psi or $85 \%$ of laboratory-cured cylinders.

Test No.

1 .

2.
Cylinder No.

$3185-3 \quad$ (FC)

$3785-4$ (FC)

3185-5

$3185-6$

3185-9 (FC)

$3185-10(F C)$

3185-11

$3185-12$
PSI at 28 Days

4010
4330
$61400.85(6140)=5219$
$60100.85(6010)=5109$
3730
4040
$56800.85(5680)=4828$
$57500.85(5750)=4888$

$H H G / 7 v$ 
RPP-RPT-55983, Rev. 0

App. Figure B-48. Nonconformance Report B-340-118

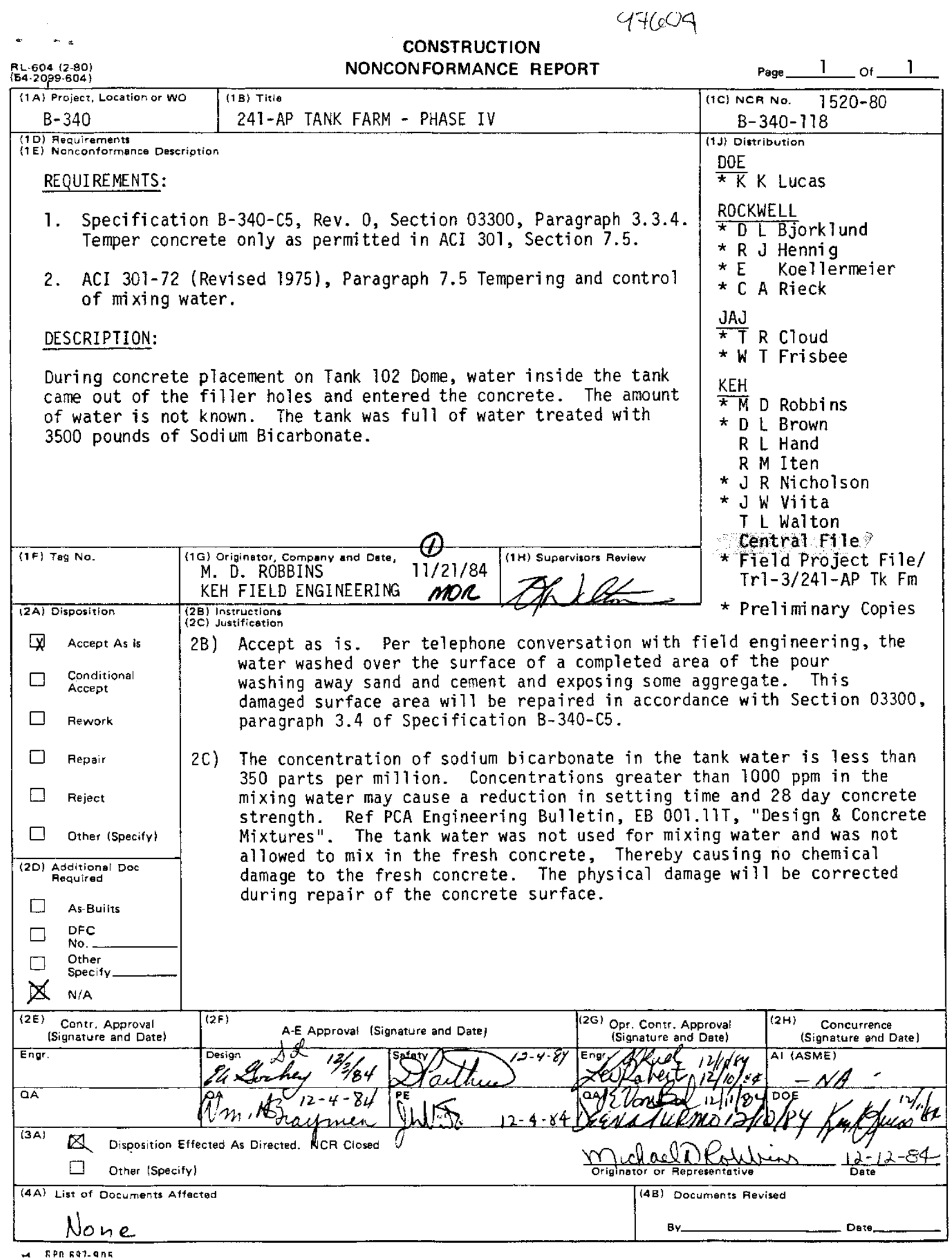


RPP-RPT-55983, Rev. 0

App. Figure B-49. Nonconformance Report B-340-120

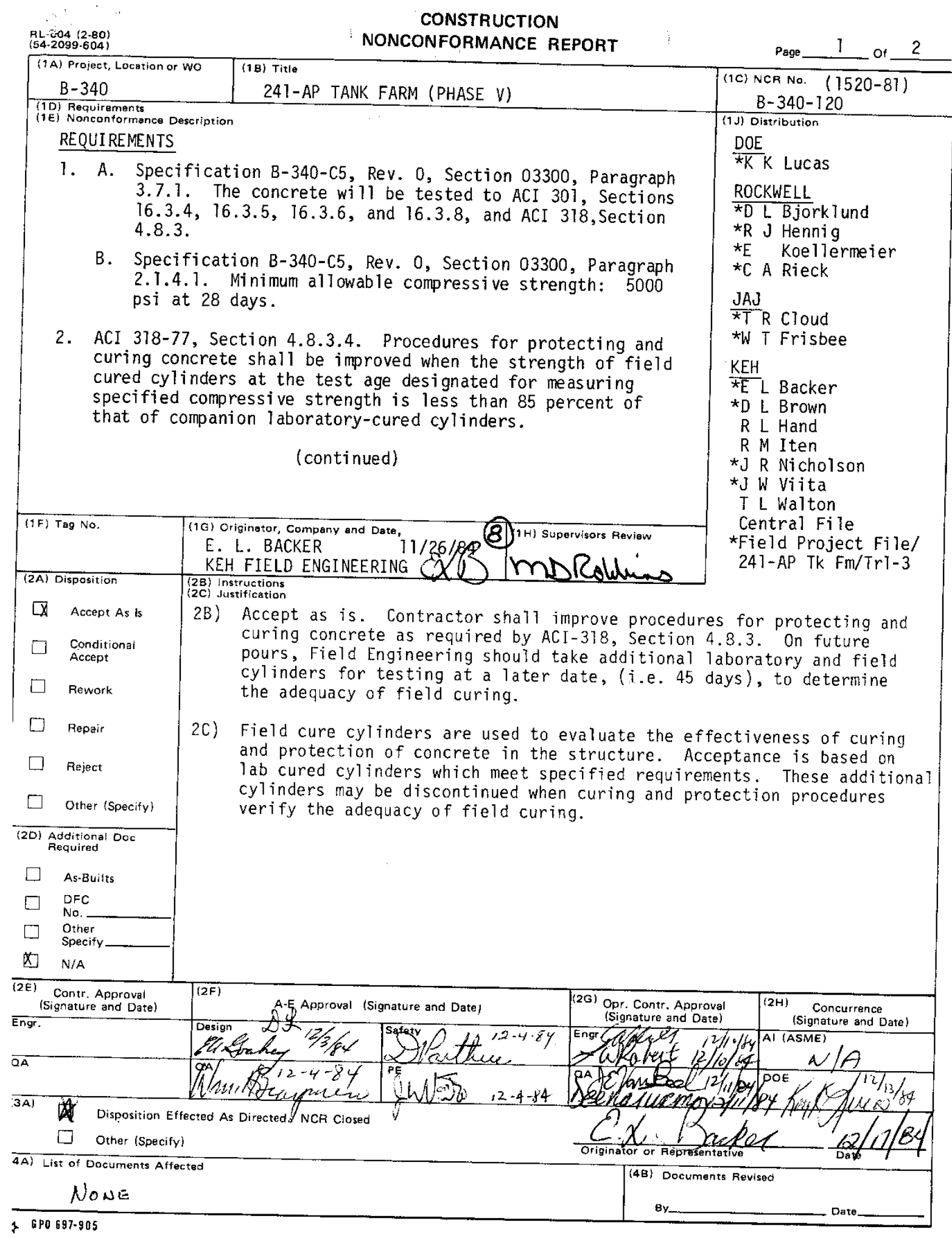


RPP-RPT-55983, Rev. 0

NCR B-340-120 (1520-81)

Page 2 of 2

\section{NONCONFORMANCE DESCRIPTION}

Tank 106 Upper Shell concrete breaks at 28 days: field cured cylinders failed to make 5000 psi or $85 \%$ of laboratory-cured cylinders.

Test No.

1.

3.

$$
\begin{array}{rr}
3186-15 & (F C) \\
-16 & (F C) \\
-17 & \\
-18 &
\end{array}
$$

PSI 628 Days

4050

4210

$64600.85(6460)=5491$

$63700.85(6370)=5415$

4130

4130

$63600.85(6360)=5406$

$64100.85(6410)=5449$

$E L B / T V$ 
RPP-RPT-55983, Rev. 0

\section{App. Figure B-50. Nonconformance Report B-340-121}

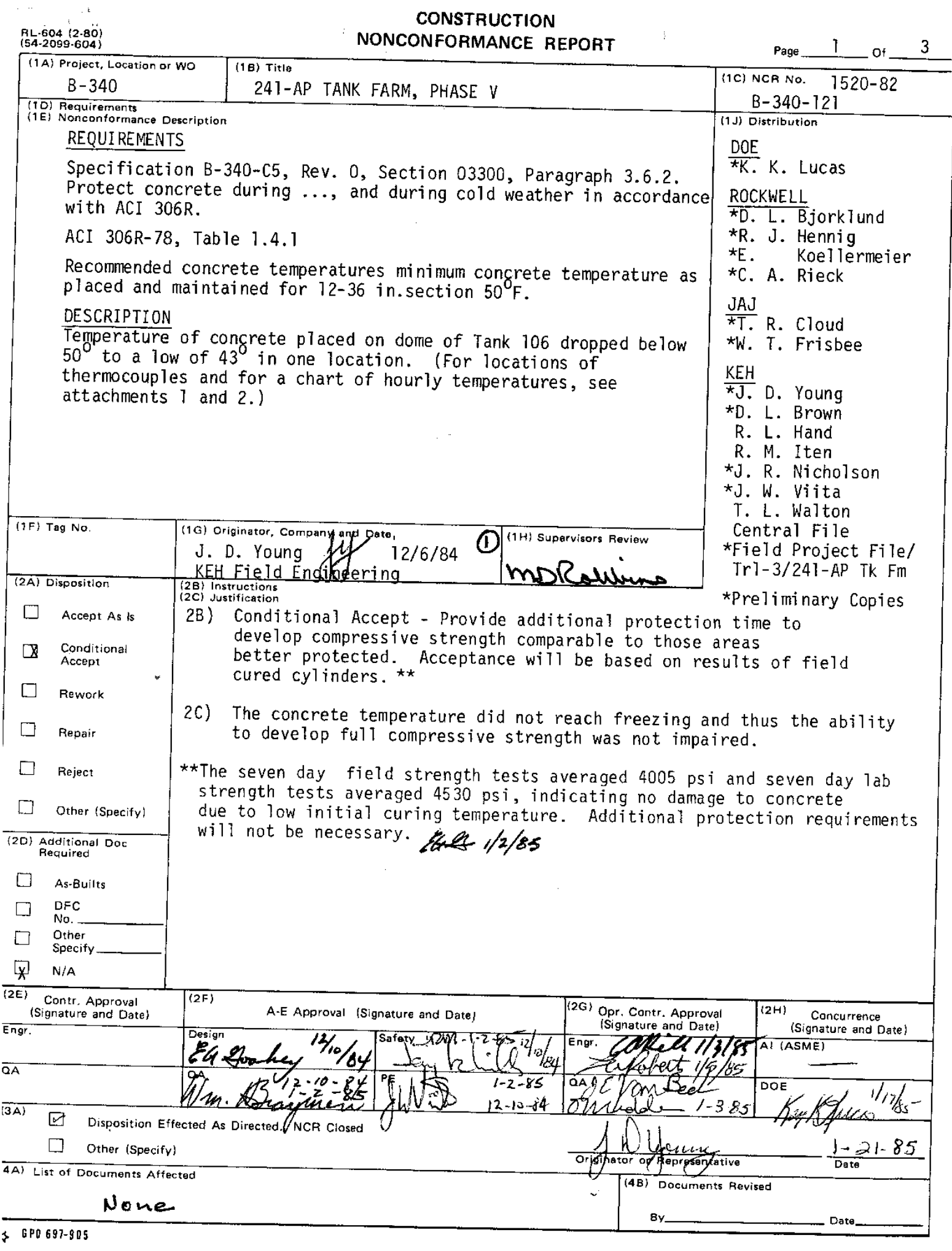


RPP-RPT-55983, Rev. 0

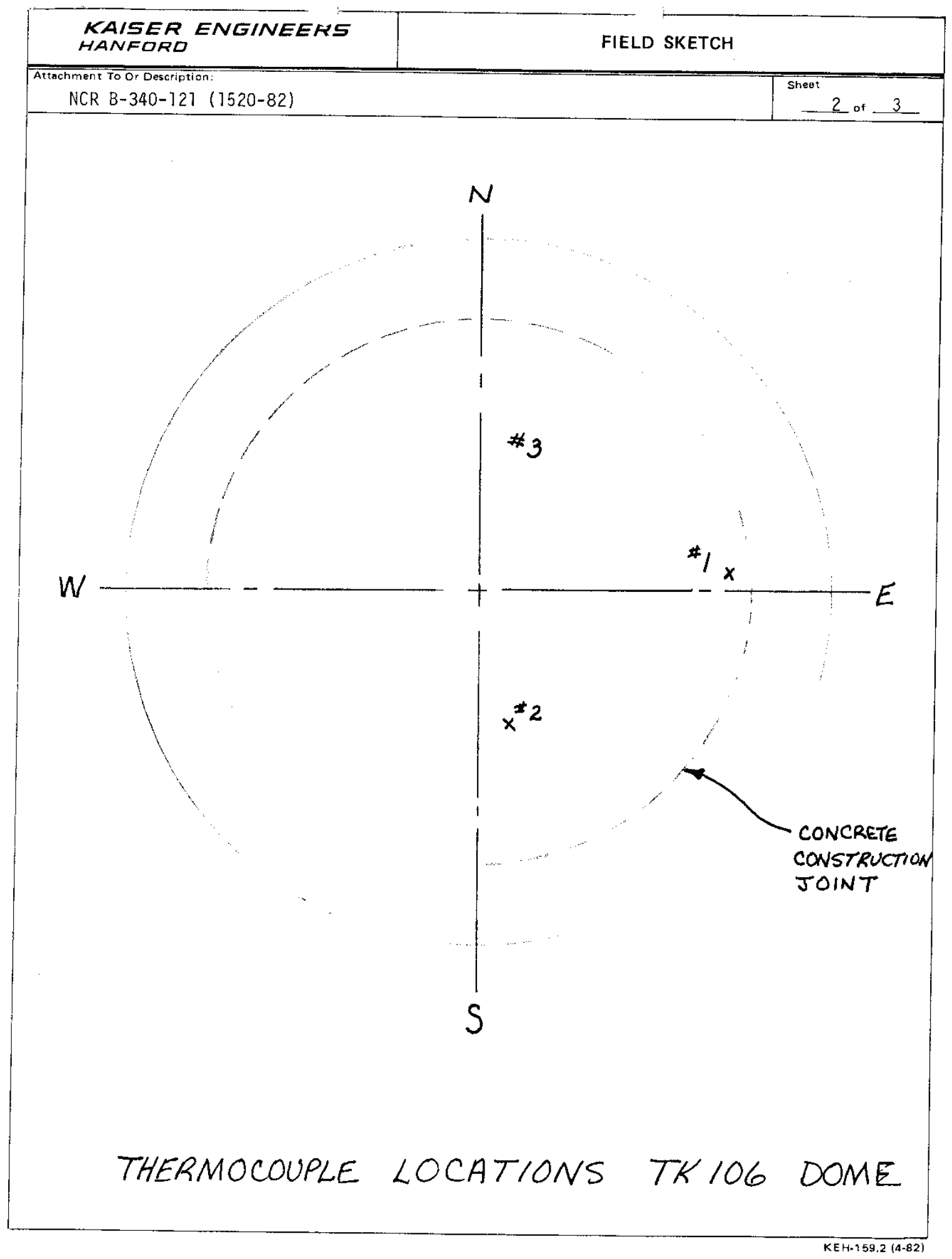

B-116 
RPP-RPT-55983, Rev. 0

\begin{tabular}{|c|c|c|c|c|c|c|}
\hline & & & $\# 1$ & $\# 2$ & $\# 3$ & Amb \\
\hline $1: 00$ & $p_{i} m$. & & 47 & 62 & 56 & -- \\
\hline $2: 00$ & $"$ & & 47 & 61 & 55 & -- \\
\hline $3: 00$ & $"$ & & 47 & 60 & 54 & 35 \\
\hline $4: 00$ & $"$ & & 46 & 59 & 53 & 32 \\
\hline $5: 00$ & $"$ & & 45 & 58 & 52 & 30 \\
\hline $6: 00$ & $"$ & & 45 & 57 & 52 & 27 \\
\hline $7: 00$ & $"$ & & 45 & 56 & 50 & 26 \\
\hline $8: 00$ & " & & 44 & 55 & 49 & 24 \\
\hline $9: 00$ & $"$ & & 44 & 55 & 49 & 23 \\
\hline $10: 00$ & $"$ " & * NOTE & 43 & 54 & 48 & 23 \\
\hline $11: 00$ & " & & 43 & 53 & 49 & 22 \\
\hline $12: 00$ & a.m. & $12 / 5 / 84$ & 43 & 53 & 50 & 22 \\
\hline $1: 00$ & $"$ & & 44 & 53 & 51 & 22 \\
\hline $2: 00$ & $"$ & & 45 & 54 & 53 & 21 \\
\hline $3: 00$ & $"$ & & 45 & 54 & 54 & 21 \\
\hline $4: 00$ & $"$ & & 46 & 55 & 56 & 2I \\
\hline $5: 00$ & $"$ & & 47 & 56 & 58 & 20 \\
\hline $6: 00$ & $"$ & & 47 & 57 & 59 & 20 \\
\hline $7: 00$ & $"$ & & 48 & 58 & 61 & 19 \\
\hline $8: 00$ & $"$ & & 48 & 59 & 62 & 19 \\
\hline $9: 00$ & $"$ & & 49 & 59 & 63 & 21 \\
\hline $10: 00$ & $"$ & & 50 & 60 & 64 & 22 \\
\hline $11: 00$ & $"$ & & 50 & 60 & 65 & 23 \\
\hline 12:00 & p.m. & & 51 & 61 & 65 & 24 \\
\hline $1: 00$ & 11 & & 52 & 62 & 67 & 25 \\
\hline $2: 00$ & $"$ & & 53 & 63 & 67 & 26 \\
\hline $3: 00$ & " & & 54 & 63 & 68 & 27 \\
\hline $4: 00$ & " & & 54 & 64 & 68 & 25 \\
\hline $5: 00$ & " & & 55 & 64 & 68 & 24 \\
\hline $6: 00$ & " & & 55 & 65 & 68 & 23 \\
\hline $7: 00$ & $"$ & & 55 & 65 & 68 & 22 \\
\hline $8: 00$ & $"$ & & 55 & 65 & 69 & 22 \\
\hline $9: 00$ & "t & & 55 & 66 & 68 & 21 \\
\hline $10: 00$ & $"$ & & 55 & 66 & 68 & 22 \\
\hline $11: 00$ & $"$ & & 55 & 66 & 68 & 21 \\
\hline $12: 00$ & a.m. & $12 / 6 / 84$ & 55 & 66 & 68 & 20 \\
\hline $1: 00$ & $"$ & & 55 & 66 & 68 & 20 \\
\hline $2: 00$ & $"$ & & 55 & 66 & 68 & 20 \\
\hline $3: 00$ & $"$ & & 55 & 66 & 68 & 20 \\
\hline $4: 00$ & 18 & & 55 & 66 & 68 & 18 \\
\hline $5: 00$ & " & & 55 & 66 & 68 & 19 \\
\hline $6: 00$ & $"$ & & 54 & 66 & 68 & 22 \\
\hline $7: 00$ & $"$ & & 54 & 66 & 67 & 23 \\
\hline
\end{tabular}

*NOTE- Cure blankets applied at this time. 
RPP-RPT-55983, Rev. 0

App. Figure B-51. Nonconformance Report B-340-124

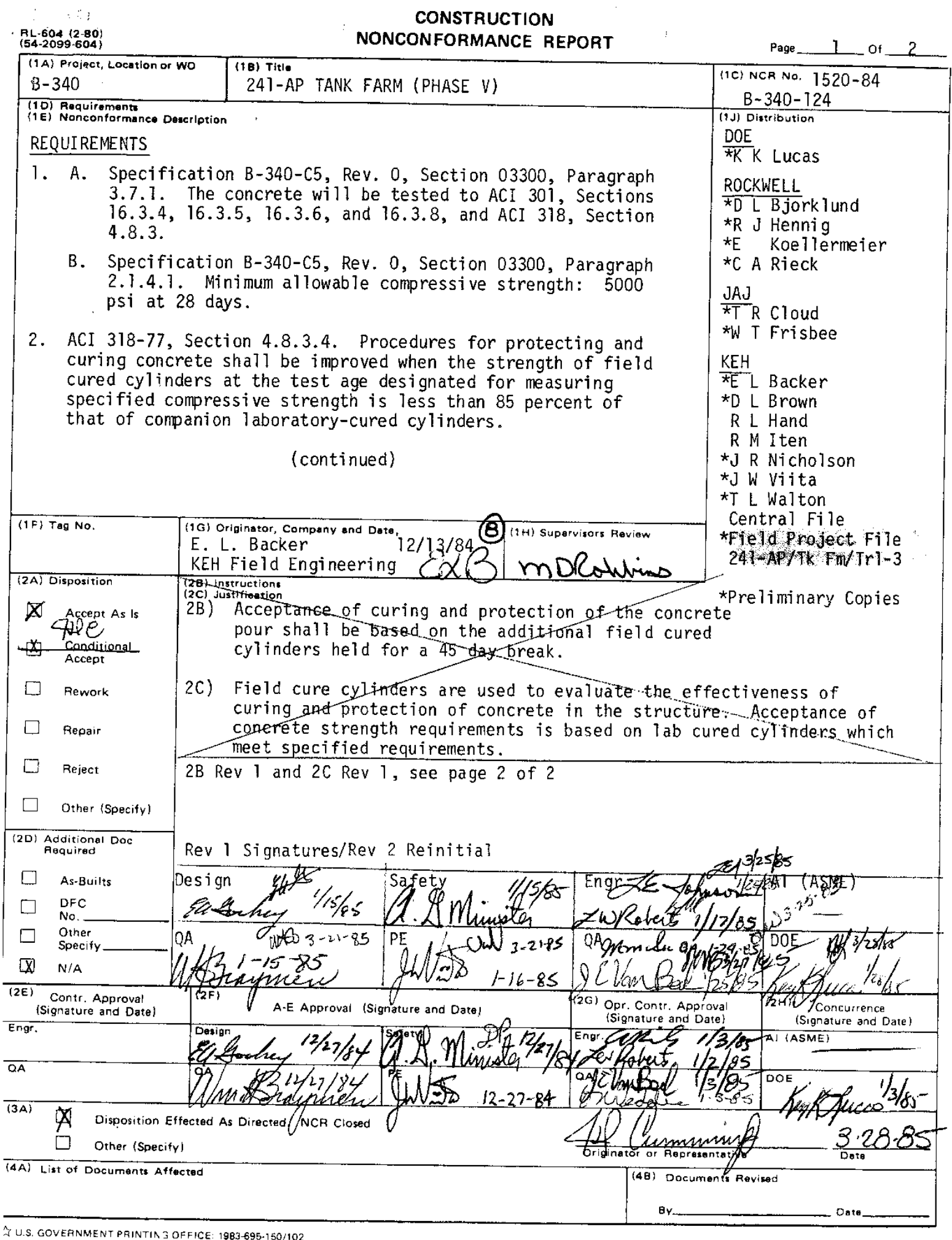


RPP-RPT-55983, Rev. 0

NCR B-340-124 (1520-84)

Page 2 of 2

NONCONFORMANCE DESCRIPTION

Tank 107 Dome - Concrete cylinder breaks at 28 days: field cured cylinders

failed to make 5000 psi or $85 \%$ of laboratory-cured cylinders.

Test No.

Cylinder No.

PSI 028 Days

1

3193-3 (FC)

$-4(F C)$

$-5$

3240

3340

$60800.85(6080)=5168$

$-6$

$60300.85(6030)=5126$

2

$\begin{array}{rll}3193-10(F C) & 3610 & \\ -11(F C) & 3640 & \\ -12 & 64000.85(6400)=5440 \\ -13 & 63300.85(6330)=5381\end{array}$

2B) Instructions Rev 1

Acceptance of curing and protection of the concrete pour shall be based on the results of tests on 45 day field cylinders taken for the dome and/or haunch pours on tanks 103, 104, 105 and 106.

2C) Justification Rev 1

Additional cylinders for 45 day strength tests are not available on this tank for testing. The results of tests on field cured cylinders from other tanks with the same concrete mix, protected by the same methods and exposed to similar weather extremes will verify the concrete will develop the specified strength.

2B) Instructions Rev 2

Accept as is

2C) Justification Rev 2

See attached letter dated $3 / 20 / 85$ by EA Goakey and JW Viita. 


\section{KAISER \\ ENGINEERS \\ HANFORD \\ INTEROFFICE MEMORANDUM}

Distribution
DATE

FROM

COPIES TO
March 20, 1985

E. A. Goakey

J. W. Viita

JOE NO.

sususcr Project B-340, NCR's B-340 - 124, 127, 129 and 134

These NCR's were written because the field cured cylinder breaks did not meet the ACI guideline of being within $85 \%$ of the 1 aboratory cured breaks. Acceptance of the concrete mix is based on the laboratory breaks where the field breaks indicate the acceptability of the curing procedures in place and the effect the weather may have on the in-place concrete.

Acceptance of NCR \#134 per the original disposition was to be based on 45 day cylinder breaks for that pour. Acceptance of the other 3 NCR's was to be based on 45 day breaks for those pours for which spare cylinders were avajlable since all curing blankets and heat were removed from all pours after the first week.

The results of the 28 day and 45 day field cured cylinder breaks are sumarized as follows:

$\begin{array}{clcc}\text { Tank } 103 \text { Dome } & \frac{\text { Pour STip \# }}{3207} & \frac{28 \text { day F.C. }}{4308 \mathrm{psi}} & \frac{45 \text { day F.C. }}{4198 \mathrm{psi}} \\ 104 \text { Dome } & 3204 & 4710 & 4905 \\ 105 \text { Dome } & 3208 & 4720 & 4408 \\ 106 \text { Dome } & 3202 & 4960 & 4832 \\ 106 \text { Haunch } & 3200 & 5342 & 5660 \\ 104 \text { Haunch } & 3203 & 4278 & 4725 \\ 103 \text { Haunch } & 3205 & 4560 & 5042 \\ 105 \text { Haunch } & 3206 & 5090 & 5110\end{array}$

Average $\quad 4746 \mathrm{psi} \quad 4860 \mathrm{psi}$

The average 28 day Field Cured cylinder breaks for the pours with the open NCR's is:

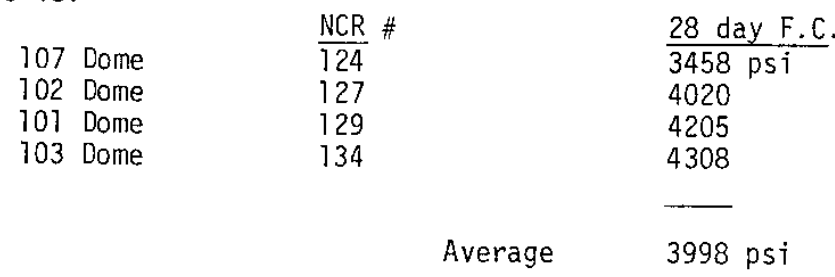

The specified concrete strength is 5000 psi for laboratory cured cylinders at 28 days. Using $85 \%$ for field cured cylinders would give us a value of 4250 psi for field cured cylinders. The average strength gain demonstrated by the 45 day cylinder breaks was lower than expected and does not give a firm indication that the field strength would meet the 4250 psi figure but does show that the concrete is continuing to gain strength despite the prolonged period of cold weather. 
RPP-RPT-55983, Rev. 0

Interoffice Memorandum

March 20, 1985

There are some notable inconsistancies in the test data such as the decrease in strength from 28 day field cure to 45 day field cure for 3 of the 8 pours for which 45 day field breaks are available. Due to these inconsistancies, it was decided to perform some tests on the in-place concrete with the Windsor Probe.

The Windsor Probe is approved for use by ASTM in comparing the relative strengths of concrete but not in determining the actual strength. To obtain a comparison to concrete which is known to be acceptable, testing was done on the Tank 108 dome in addition to the 4 domes with open NCR's. The Tank 108 dome had an average 28 day field cure strength of $4890 \mathrm{psi}$ and a laboratory cure strength of $6325 \mathrm{psi}$.

A predicted field cure strength of the concrete was obtained by comparing the Windsor Probe results for Tank 108 and the other domes with the field cure strength for Tank 108. The following formula was used:

Probe results Tank "X" $X \quad$ P $4890 \mathrm{psi}=$ Predicted Field Cure Strength

Probe resuTts Tank 108

Windsor Probe results for Tank 108 indicated an average strength of 5150psi

(8 tests) (concrete age of 113 days)

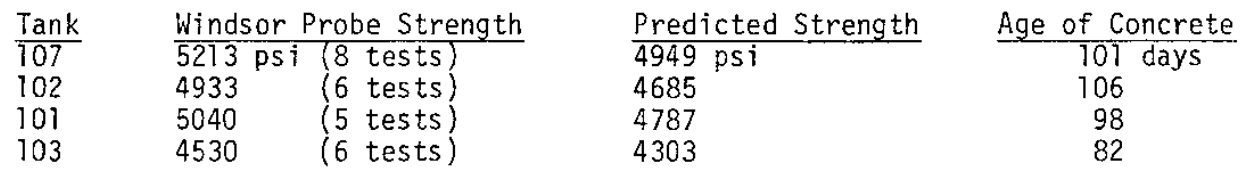

(Tank 103 was tested twice. There were probiems with the roughness of the concrete surface possibly effecting the results of the test so the first test was discarded; the test locations were ground to an acceptable smoothness (allowed by ASTM) and new tests parformed.)

The results indicate predicted field cure strength in excess of 4250 psi with an actual increase of essentially zero (0) (4303 versus 4308) for the Tank 103 dome to approximately 1500 psi for the Tank 107 dome when compared to the field cured cylinder results. These predicted strengths are considered somewhat conservative since the base results from Tank 108 have the longest cure time with Tank 103 having 31 days less cure time.

In summary, considering the Windsor Probe results on the in-place concrete along with the cylinder test results (both lab. cured and field cured) all encasement concrete will develop the required strength to properly perform as intended in the design. Some of the individual tests may indicate a problem but the overall results indicate that the contractor has supplied and placed the concrete as specified JWV/ss

Distribution: Attachment to NCR B-340-124

Attachment to NCR B-340-127

Attachment to NCR B-340-129

Attachment to NCR B-340-134

EA Goakey

JW Viita File

Central File

LB 
RPP-RPT-55983, Rev. 0

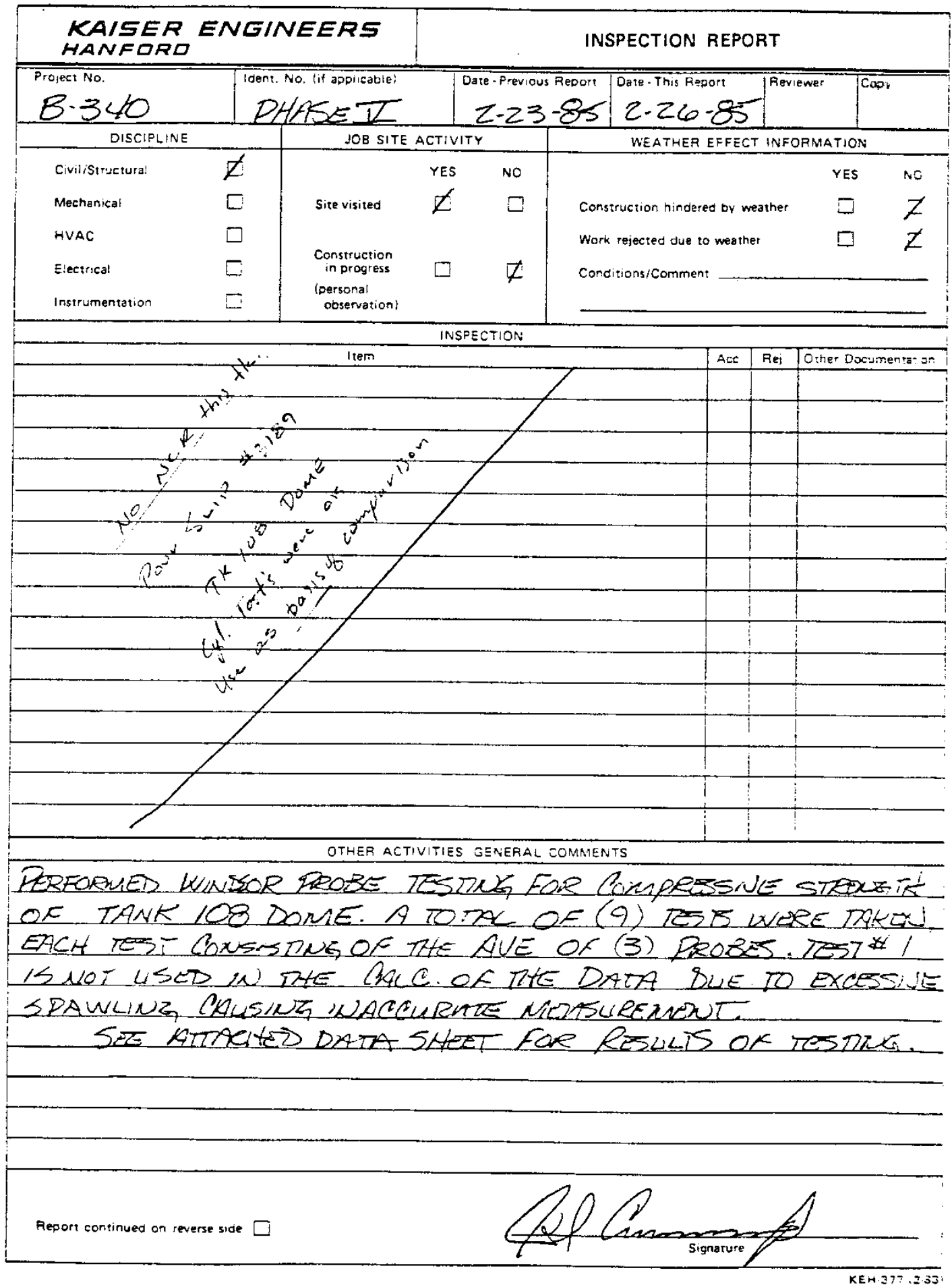


RPP-RPT-55983, Rev. 0

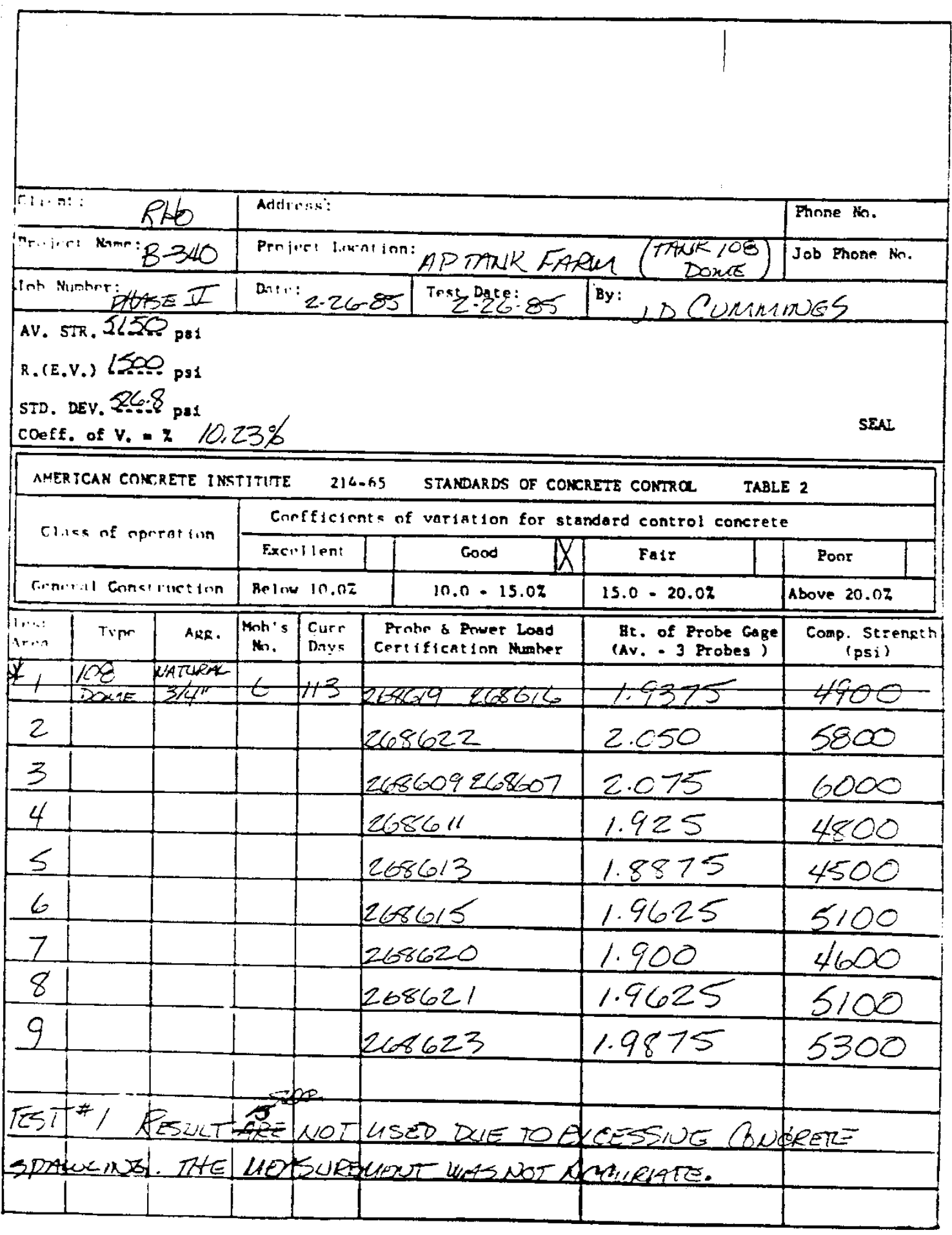


TARE 3 - FACTORS FOR COAPUTING WITHIM-TEST STANDARD DEVIATIONA

\begin{tabular}{|c|c|}
\hline $\begin{array}{l}\text { Wuber of } \\
\text { Spec ines: }\end{array}$ & $1 / d_{2}$ \\
\hline $\begin{array}{r}2 \\
3 \\
4 \\
5 \\
6 \\
7 \\
8 \\
9 \\
10\end{array}$ & $\begin{array}{l}0.3865 \\
0.5907 \\
0.4857 \\
0.4299 \\
0.3946 \\
0.3698 \\
0.3512 \\
0.3367 \\
0.3249\end{array}$ \\
\hline
\end{tabular}

* Froo Table B2, "Manual on Quality Control of Materials", ASTM Special Technical Publication No. 15-C.

NOTE: Table may be used to report as any as ten tests.

AMERICAN CONCRETE INSTITUE

CopP

STANDARD 2i4-65

TABLE 2 - STAKOARDS OF COMCRETE CONTROL

\begin{tabular}{|c|c|c|c|c|}
\hline \multirow{2}{*}{ Class of operation } & \multicolumn{4}{|c|}{ Coefficient of variation for different control standarts } \\
\cline { 2 - 5 } & Excelleat & Good & Fa1s & Poc: \\
\hline Over-all variation: & Below & 10.0 to & 15.0 to & Above \\
General construction & 10.0 & 15.0 & 20.0 & 20.0 \\
Laboratory Control & Below & 5.0 to & 7.0 to & Above \\
& 5.0 & 7.0 & 10.0 & 10.0 \\
Within-test variations: & Below & 4.0 to & 5.0 to & Above \\
Field control & 4.0 & 5.0 & 6.0 & 6.0 \\
Laboratory control & Below & 3.0 to & 4.0 to & Above \\
& 3.0 & 4.0 & 5.0 & 5.0 \\
& & & & \\
\hline
\end{tabular}

Note: These standarda represent the average for 28 -day eylinder coaputed from a lazge number of teata. Different values for otber than average concretes can be
expected.

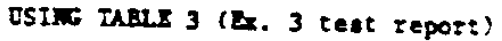

Alavere Nob'a 14 Aggregate

Exposed Probe Hesght

A B $C$

1.750 inch 1.825 inch 5100 psi corver:ion from Windsor collum $\$ 4$

Range = 5275 (181) - 4750 (LOW) $=525$ ps1

Std. Dev. = Range $\times \underline{0.5907}$. (Erou Iable 3)

Thus: $525 \times .5907=310$ (Std. Dev.)

Coeff. of var. - Std. Dev. : Av. psi $\times 100$ $310 \div 5041$ (av.) $=.614 \times 100=6.16 \%$ 
$40+6-60=-7$

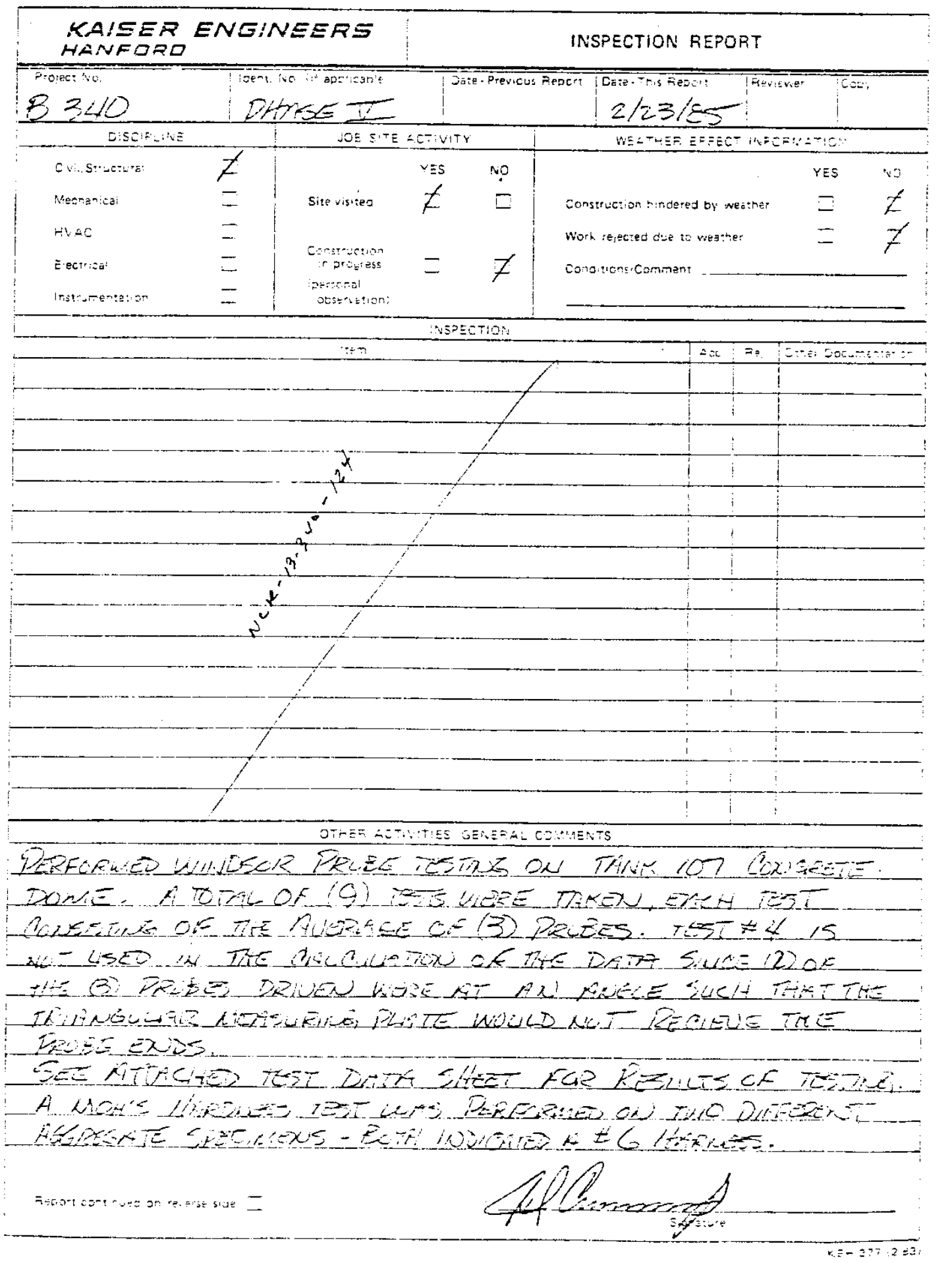


RPP-RPT-55983, Rev. 0

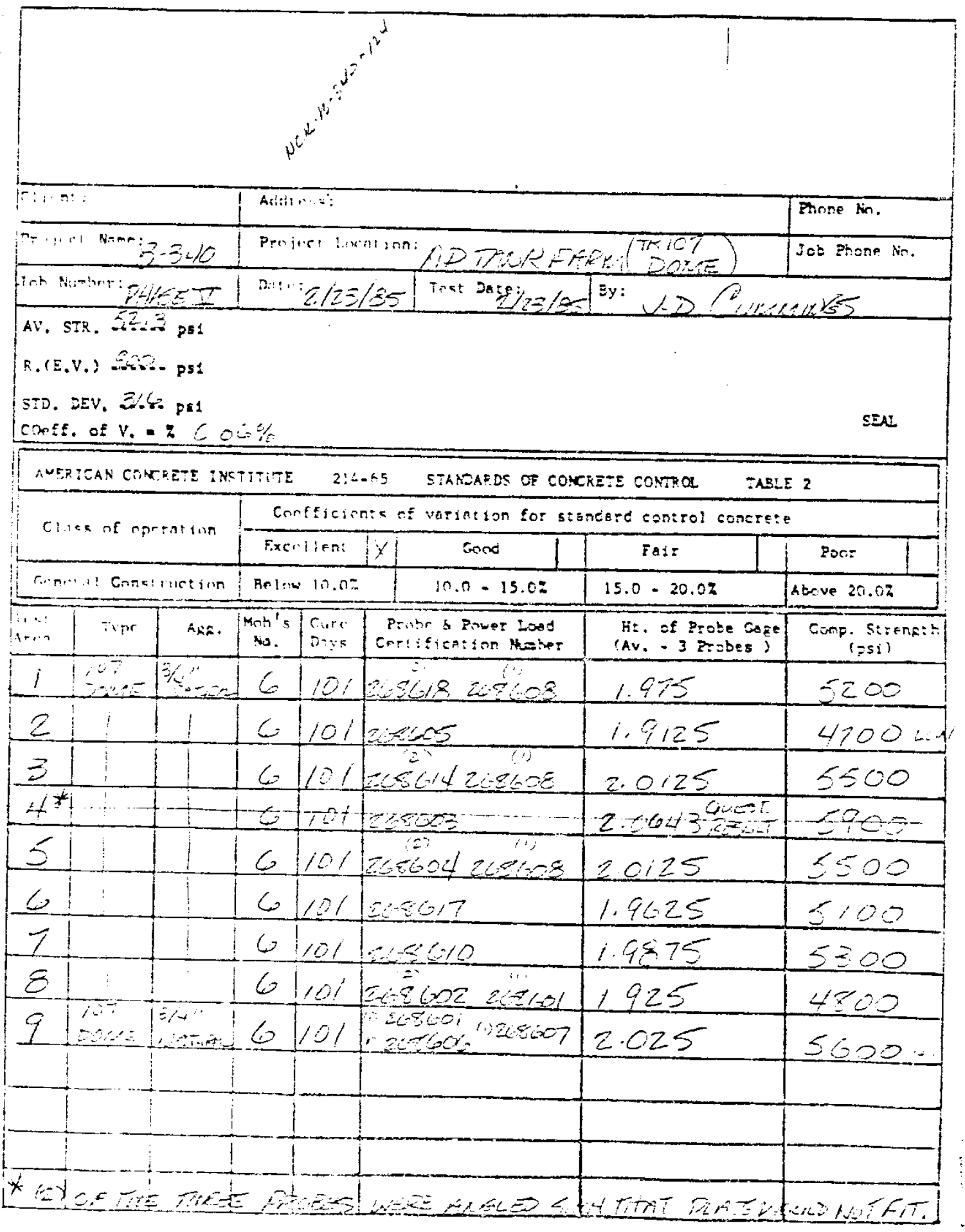


RPP-RPT-55983, Rev. 0

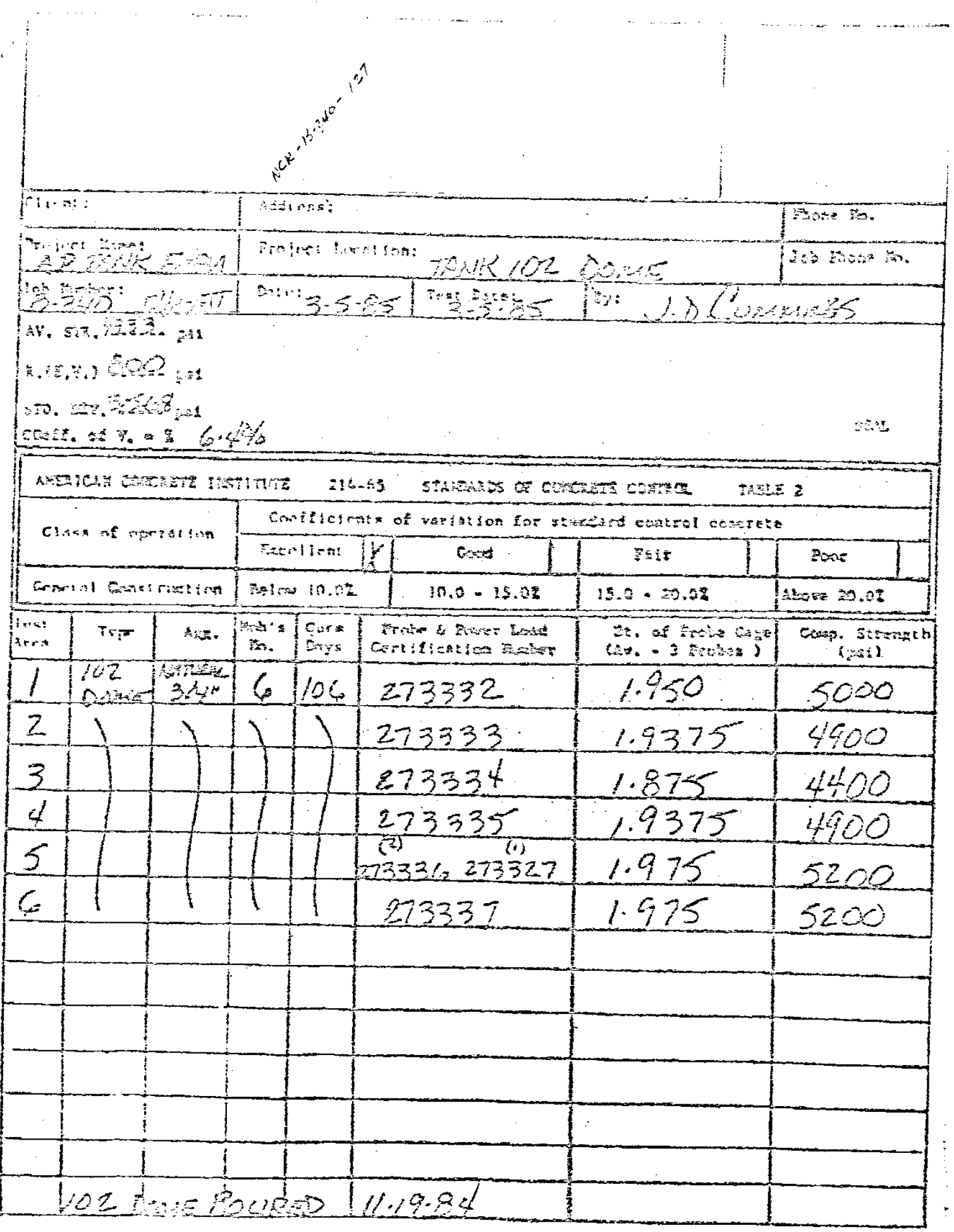


RPP-RPT-55983, Rev. 0

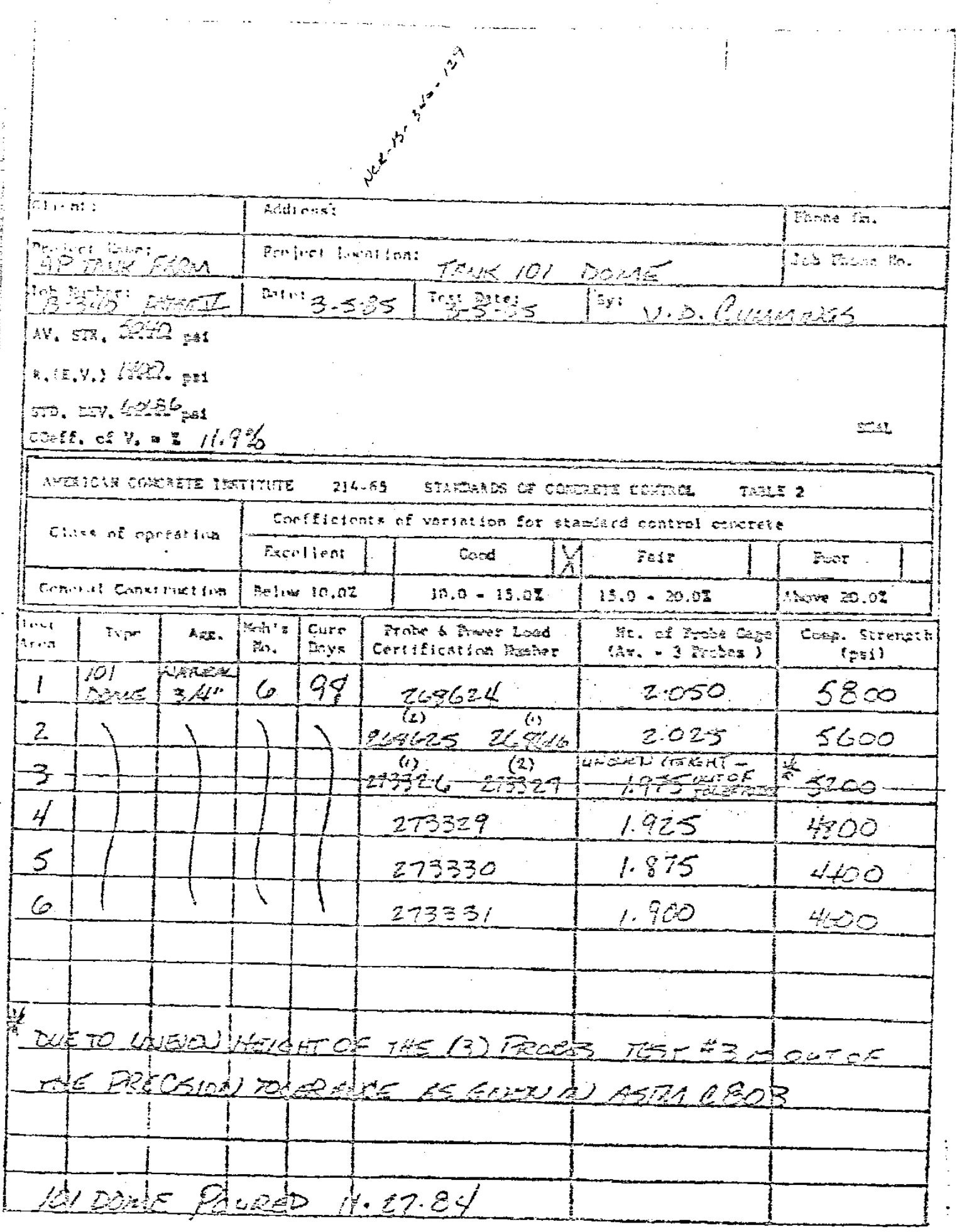


RPP-RPT-55983, Rev. 0

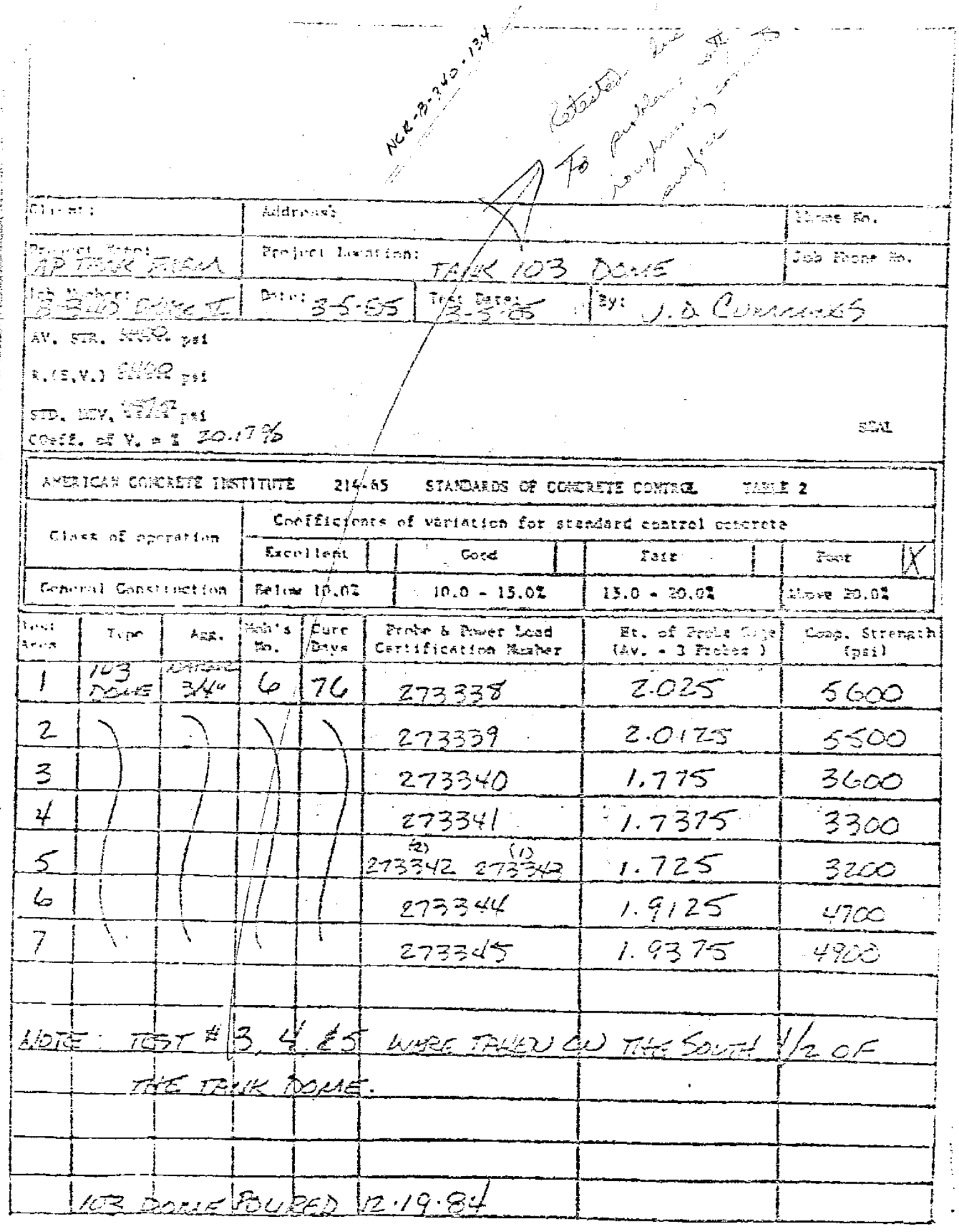


RPP-RPT-55983, Rev. 0

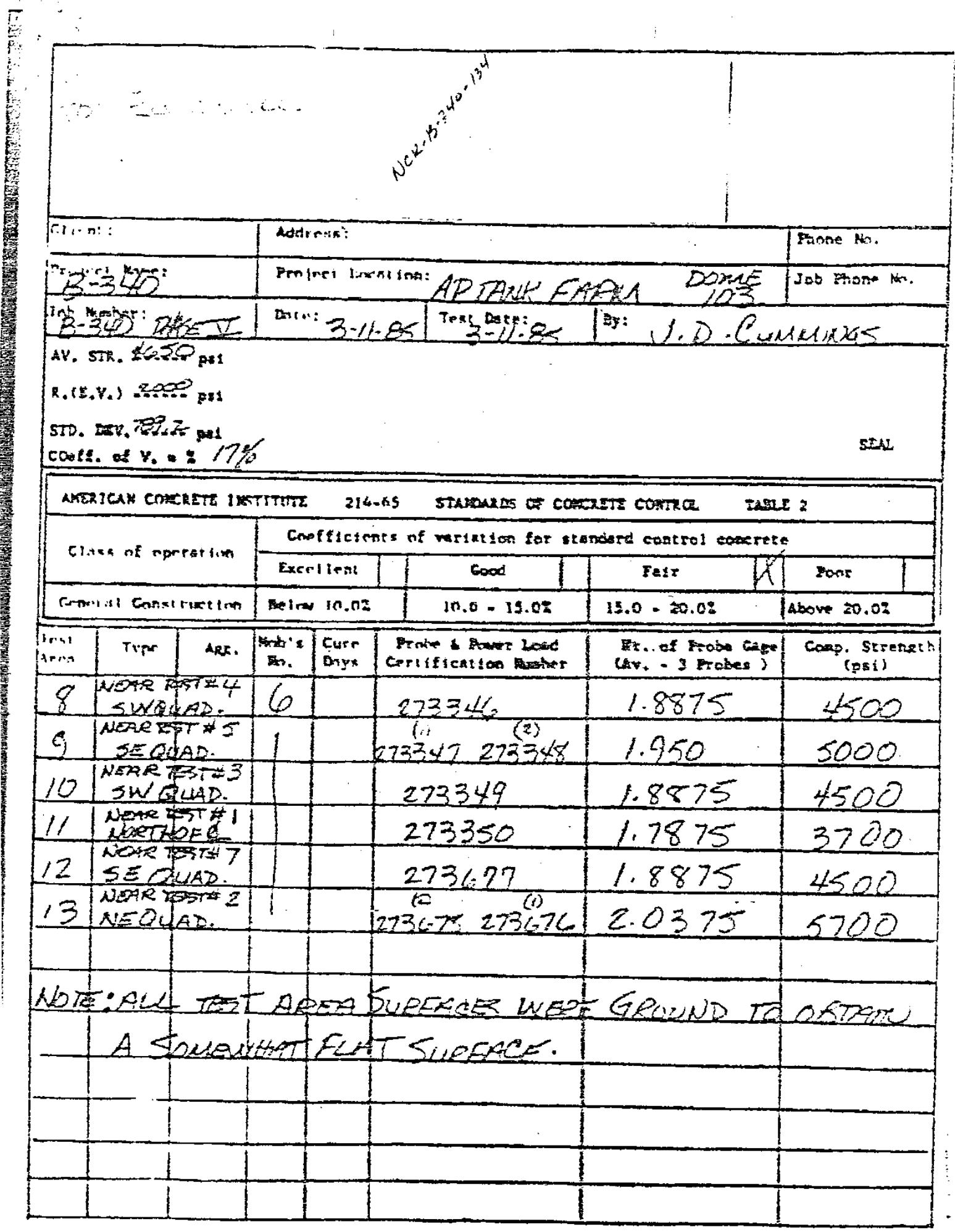


RPP-RPT-55983, Rev. 0

App. Figure B-52. Nonconformance Report B-340-125

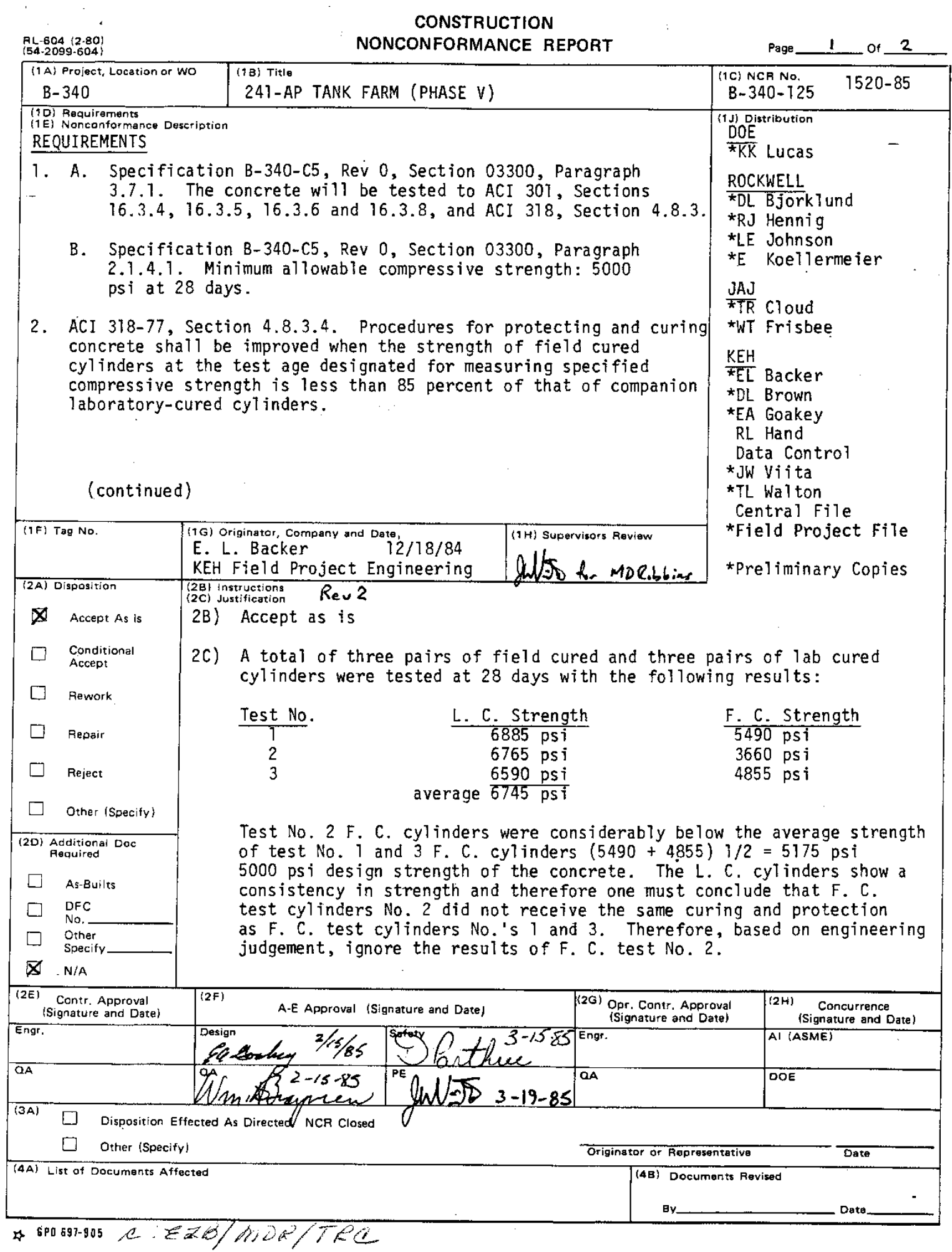


RPP-RPT-55983, Rev. 0

NCR B-340-125

Page 2

NONCONFORMANCE DESCRIPTION

Tank 105 Lower She 11 concrete breaks at 28 days: Field cured cylinders failed to make 5000 psi or $85 \%$ of laboratory-cured cylinders.

Test No.

2
Cylinder No.

$3195-93480(F C)$

-103840 (FC)

$-116720$

$-126810$
PSI 28 Days

$0.85(6720)=5712$

$0.85(6810)=5789$ 
App. Figure B-53. Nonconformance Report B-340-126

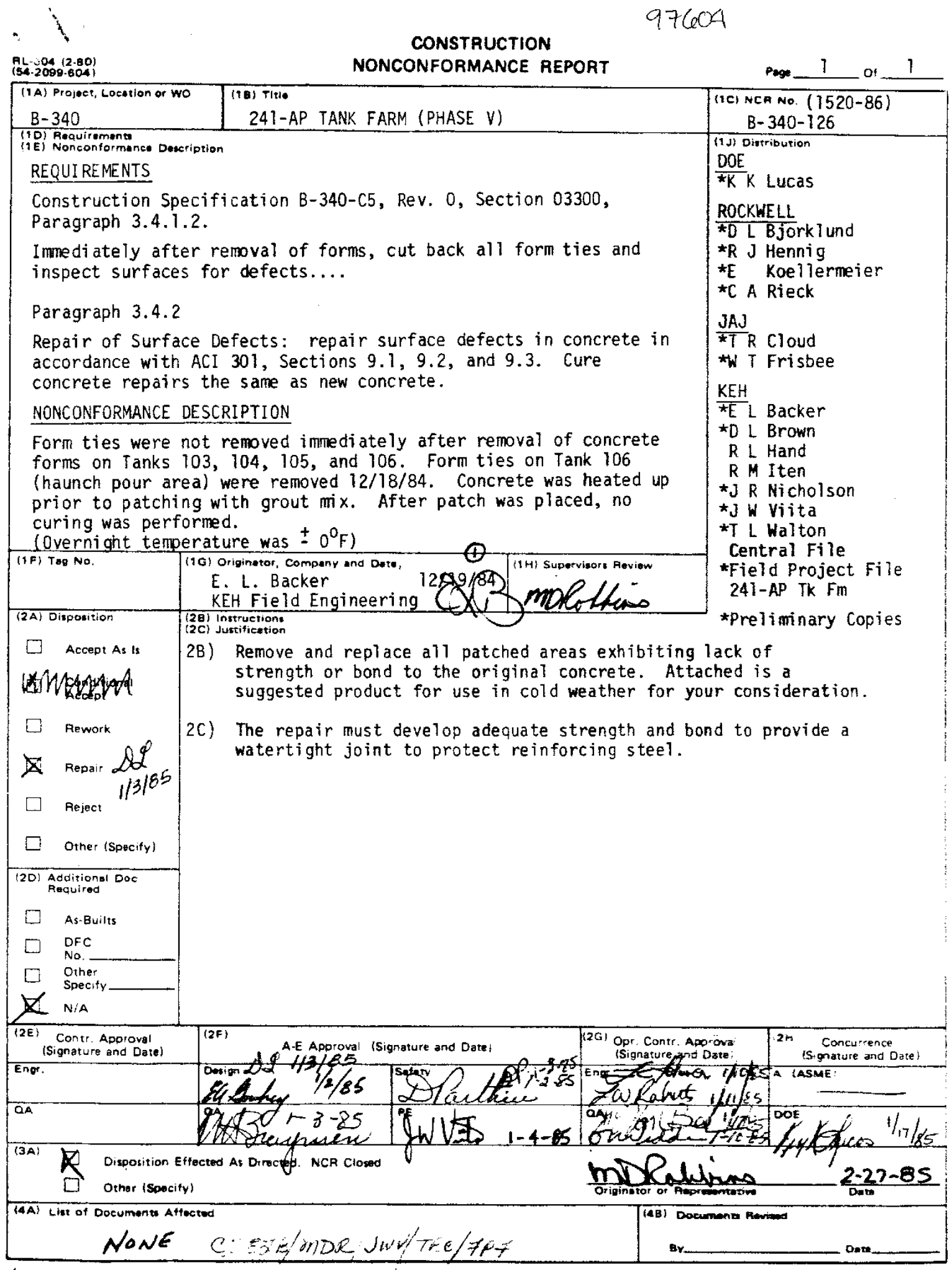

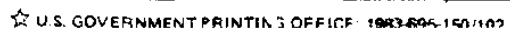




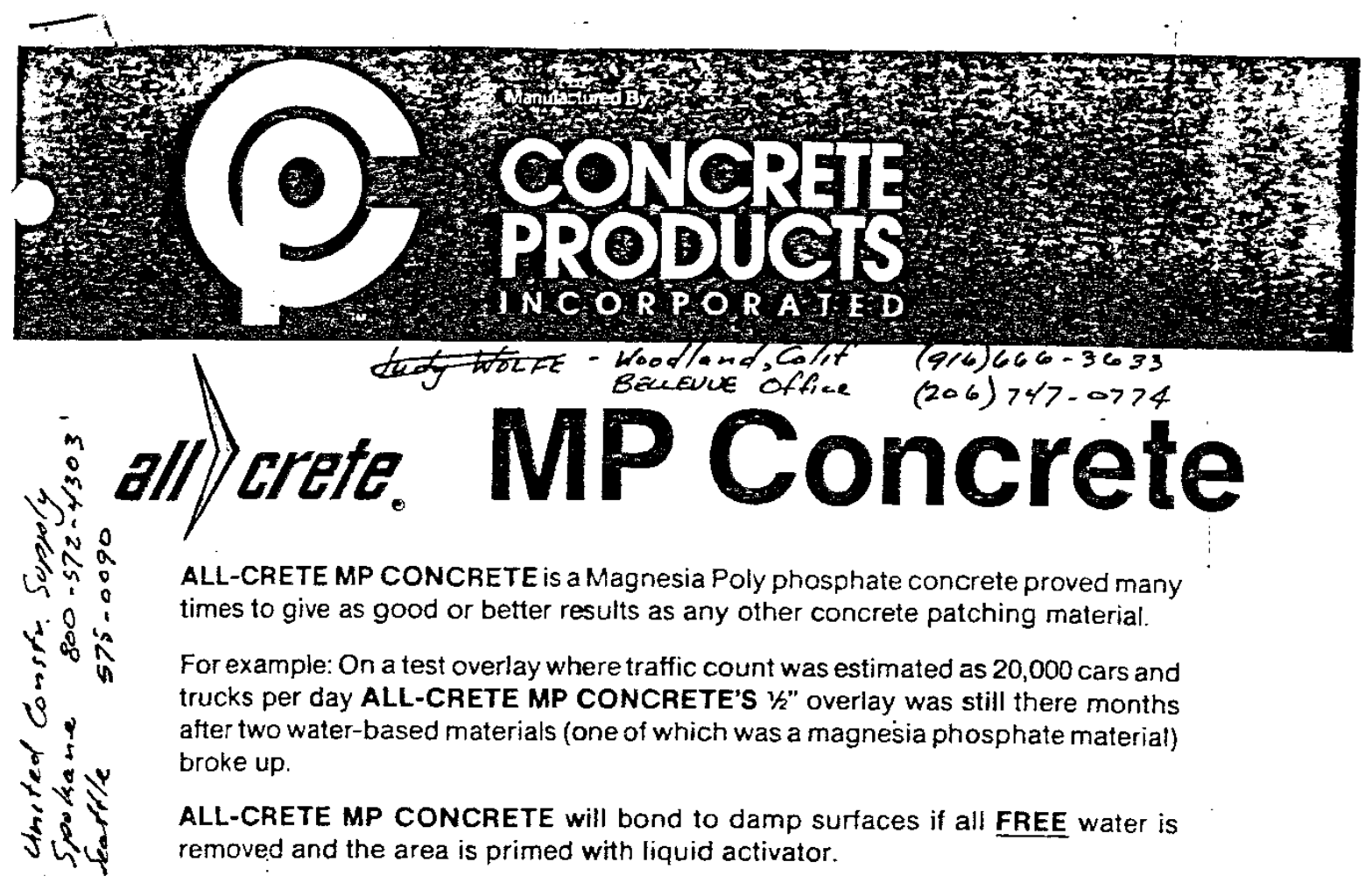

ALL-CRETE MP CONCRETE DOES NOT have to be exact in recommended 1 to 5 ratio of liquid to dry material to maintain its properties. It can be mixed more fluid to pour into small cracks and to achieve thinner overlays.

It needs no saw-cutting. Just break out all loose rock, etc., blow out the dust and add ALL-CRETE MP CONCRETE. It feathers out to less than $1 / 6 "$.

ALL-CRETE MP CONCRETE is easily mixed in small quantities by hand or trowel or in mixers up to 3 or 4 units at a time. It can also be "gunned" into place with a modified gunite type rig.

ALL-CRETE MP CONCRETE bonds to practically anything except slick plastics and oily surfaces.

ALL-CRETE MP CONCRETE can be used with glass or steel fibers where required with outstanding results.

ALL-CRETE MP CONCRETE will withstand heat up to $700-800^{\circ} \mathrm{F}$.

ALL-CRETE MP CONCRETE can be put into place at sub-freezing temperatures, possibly needing only heating with a torch to start the exothermic reaction. Once started it needs no further "HELP". Warmed aggregate added in deeper sections will do the same.

To accelerate the set apply heat. To retard the set cool the fiquid.

Clean-up is with water. Hand tools and mixing equipment should be washed off before firm set.

ALL-CRETE MP CONCRETE sets rapidly. Traffic can be resumed over repaired holes in as little as $\mathbf{3 0}$ minutes and on overlays in $\mathbf{2}$ to 3 hours.

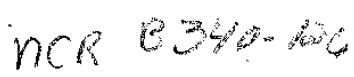


RPP-RPT-55983, Rev. 0

App. Figure B-54. Nonconformance Report B-340-127

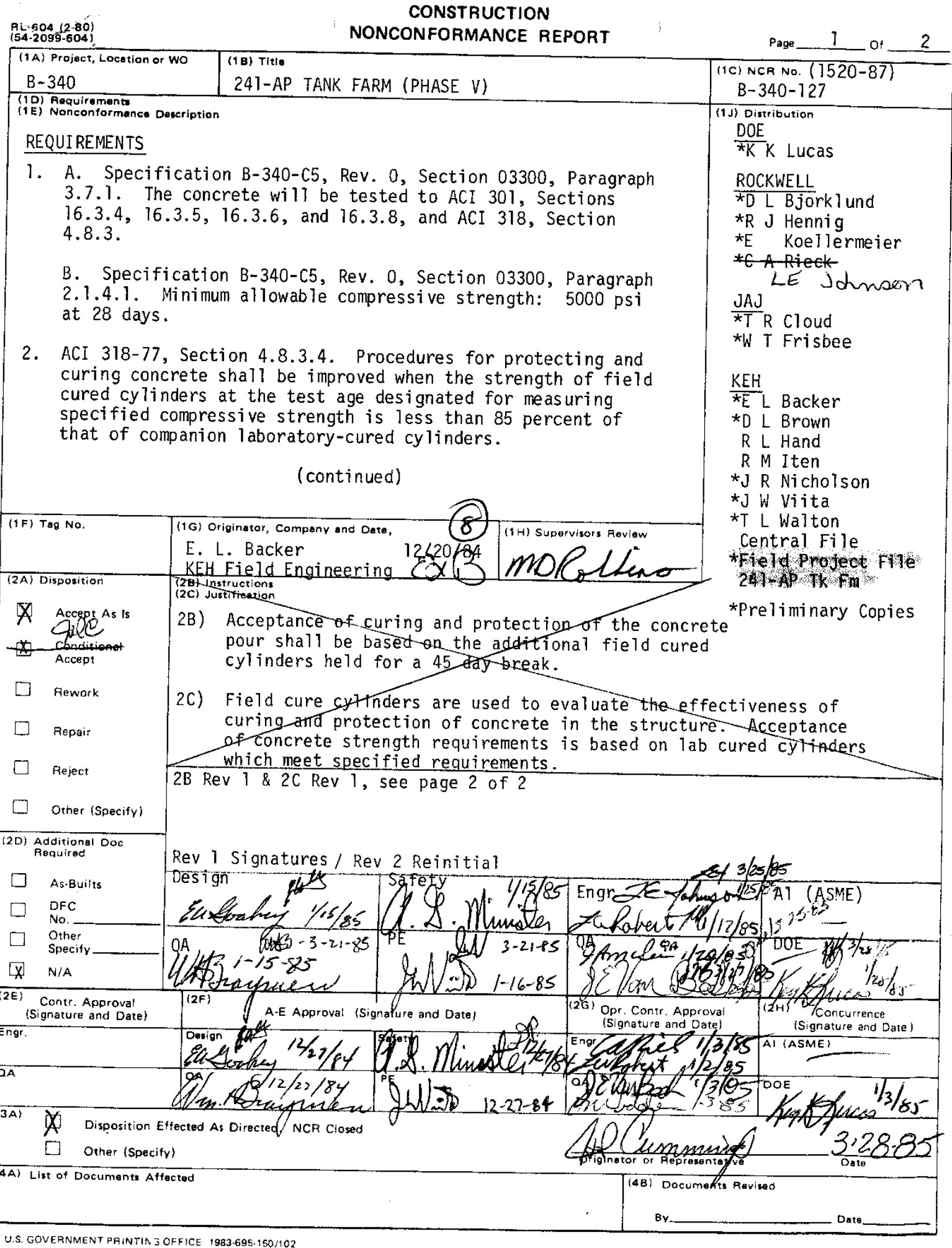


RPP-RPT-55983, Rev. 0

NCR B-340-127 (1520-87)

Page 2 of 2

Tank 102 Dome concrete cylinder breaks at 28 days: field cured cylinders failed to make 5000 psi of laboratory-cured cylinders.

Test No.

1.

2.
Cylinder No.

$3198-4 \quad(F C)$

-5 (FC)

$-6$

$-7$

$3198-11$
PSI 028 Days

4240

4190

5950

$0.85(5870)=4990$

3800

3850

$52000.85(5200)=4420$

$50800.85(5080)=4318$

2B) Instructions Rev I

Acceptance of curing and protection of the concrete pour shall be based on the results of tests on 45 day field cylinders taken for the dome and/or haunch pours on tanks 103, 104, 105 and 106.

2C) Justification Rev I

Additional cylinders for 45 day strength tests are not available on this tank for testing. The results of tests on field cured cylinders from other tanks with the same concrete mix, protected by the same methods and exposed to similar weather extremes will verify the concrete will develop the specified strength.

2B) Instructions $\operatorname{Rev} 2$

Accept as is

2C) Justification Rev 2

See attached letter dated $3 / 20 / 85$ by EA Goakey and JW Viita 


\section{KAISER \\ ENGINEERS HANFORD \\ INTEROFFICE MEMORANDUM}

ro Distribution

COPIES To
DATE
March 20, 1985
FROM
E. A. Goakey
J. W. Viita $g \mathrm{~N}$

SOB NO.

subsect Project B-340, NCR's B-340 - 124, 127, 129 and 134

These NCR's were written because the field cured cylinder breaks: did not meet the ACI guideline of being within $85 \%$ of the laboratory cured breaks. Acceptance of the concrete $\mathrm{mix}$ is based on the laboratory breaks where the field breaks indicate the acceptability of the curing procedures in place and the effect the weather may have on the in-place concrete.

Acceptance of NCR \#134 per the original disposition was to be based on 45 day cylinder breaks for that pour. Acceptance of the other 3 NCR's was to be based on 45 day breaks for those pours for which spare cylinders were available since all curing blankets and heat were removed from all pours after the first week.

The results of the 28 day and 45 day field cured cylinder breaks are summarized as follows:

$\begin{array}{llll}\text { Tank } 103 \text { Dome } & \text { Pour Slip \# } & 28 \text { day F.C. } & \text { 45 day F.C. } \\ 104 \text { Dome } & 3207 & 4308 \text { psi } & 498 \text { psi } \\ 105 \text { Dome } & 3204 & 4710 & 4408 \\ 106 \text { Dome } & 3208 & 4720 & 4832 \\ 106 \text { Haunch } & 3202 & 5960 & 5660 \\ 104 \text { Haunch } & 3203 & 4278 & 4725 \\ 103 \text { Haunch } & 3205 & 4560 & 5042 \\ 105 \text { Haunch } & 3206 & 5090 & 5110 \\ & & & \\ & & & 4860 \text { psi }\end{array}$

The average 28 day field Cured cylinder breaks for the pours with the open NCR's is:

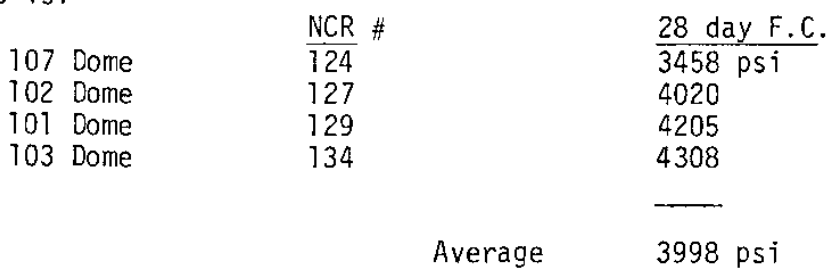

The specified concrete strength is 5000 psi for laboratory cured cylinders at 28 days. Using $85 \%$ for field cured cylinders would give us a value of 4250 psi for field cured cylinders. The average strength gain demonstrated by the 45 day cylinder breaks was lower than expected and does not give a firm indication that the field strength would meet the 4250 psi figure but does show that the concrete is continuing to gain strength despite the prolonged period of cold weather. 
RPP-RPT-55983, Rev. 0

Interoffice Memorandum

March 20, 1985

There are some notable inconsistancies in the test data such as the decrease in strength from 28 day field cure to 45 day field cure for 3 of the 8 pours for which 45 day field breaks are available. Due to these inconsistancies, it was decided to perform some tests on the in-place concrete with the Windsor Probe.

The Windsor Probe is approved for use by ASTM in comparing the relative strengths of concrete but not in determining the actual strength. To obtain a comparison to concrete which is known to be acceptable, testing was done on the Tank 108 dome in addition to the 4 domes with open NCR's. The Tank 108 dome had an average 28 day field cure strength of $4890 \mathrm{psi}$ and a laboratory cure strength of 6325 psi.

A predicted field cure strength of the concrete was obtained by comparing the Windsor Probe results for Tank 108 and the other domes with the field cure strength for Tank 108. The following formula was used:

$\frac{\text { Probe results Tank "X" }}{\text { Probe results Tank } 108} \quad X \quad 4890$ psi $\quad=\quad$ Predicted Field Cure Strength

Windsor Probe results for Tank 108 indicated an average strength of 5150psi ( 8 tests) (concrete age of 113 days)

\begin{tabular}{|c|c|c|c|}
\hline $\begin{array}{l}\text { Tank } \\
107 \\
102 \\
101\end{array}$ & $\begin{array}{ll}\text { Windsor Probe Strength } \\
5213 \text { psi } & \text { (8 tests) } \\
4933 & \text { (6 tests) } \\
5040 & \text { (5 tests) } \\
4530 & \text { (6 tests) }\end{array}$ & $\begin{array}{l}\text { Predicted Strength } \\
4949 \text { psi } \\
4685 \\
4787 \\
4303\end{array}$ & $\begin{array}{c}\text { Age of Concrete } \\
101 \text { days } \\
106 \\
98 \\
82\end{array}$ \\
\hline
\end{tabular}

(Tank 103 was tested twice. There were problems with the roughness of the concrete surface possibly effecting the results of the test so the first test was discarded; the test locations were ground to an acceptable smoothness (allowed by ASTM) and new tests performed.)

The results indicate predicted field cure strength in excess of 4250 psi with an actual increase of essentially zero (0) (4303 versus 4308 ) for the Tank 103 dome to approximately 1500 psi for the Tank 107 dome when compared to the field cured cylinder results. These predicted strengths are considered somewhat conservative since the base results from Tank 108 have the longest cure time with Tank 103 having 31 days less cure time.

In summary, considering the Windsor Probe results on the in-place concrete along with the cylinder test results (both lab. cured and field cured) all encasement concrete wilT develop the required strength to properly perform as intended in the design. Some of the individual tests may indicate a problem but the overall results indicate that the contractor has supplied and placed the concrete as specified JWV/sS

Distribution: Attachment to NCR B-340-124 Attachment to NCR B-340-127 Attachment to NCR B-340-129 Attachment to NCR B-340-134 EA Goakey JW Vita File Central File LB 
RPP-RPT-55983, Rev. 0

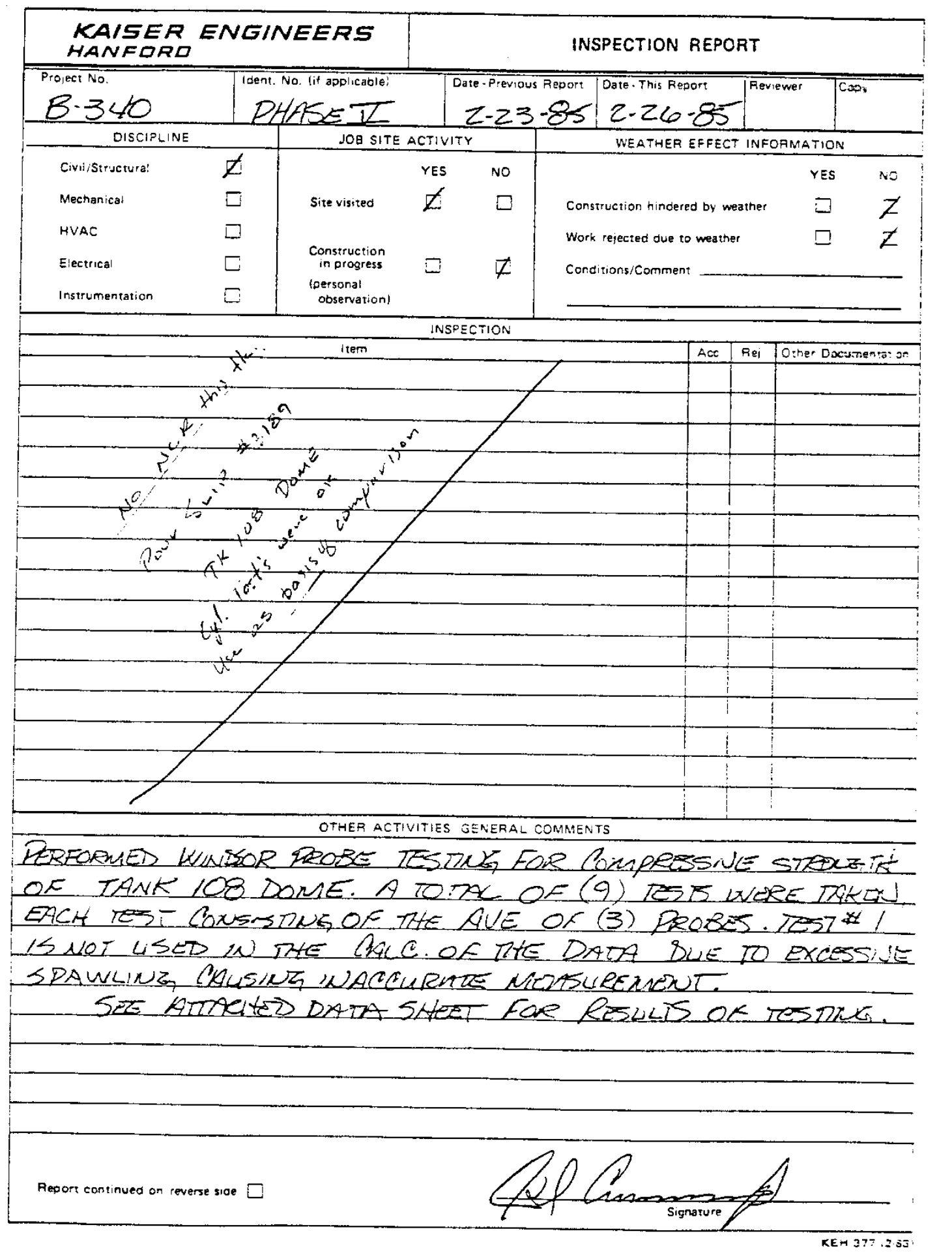


RPP-RPT-55983, Rev. 0

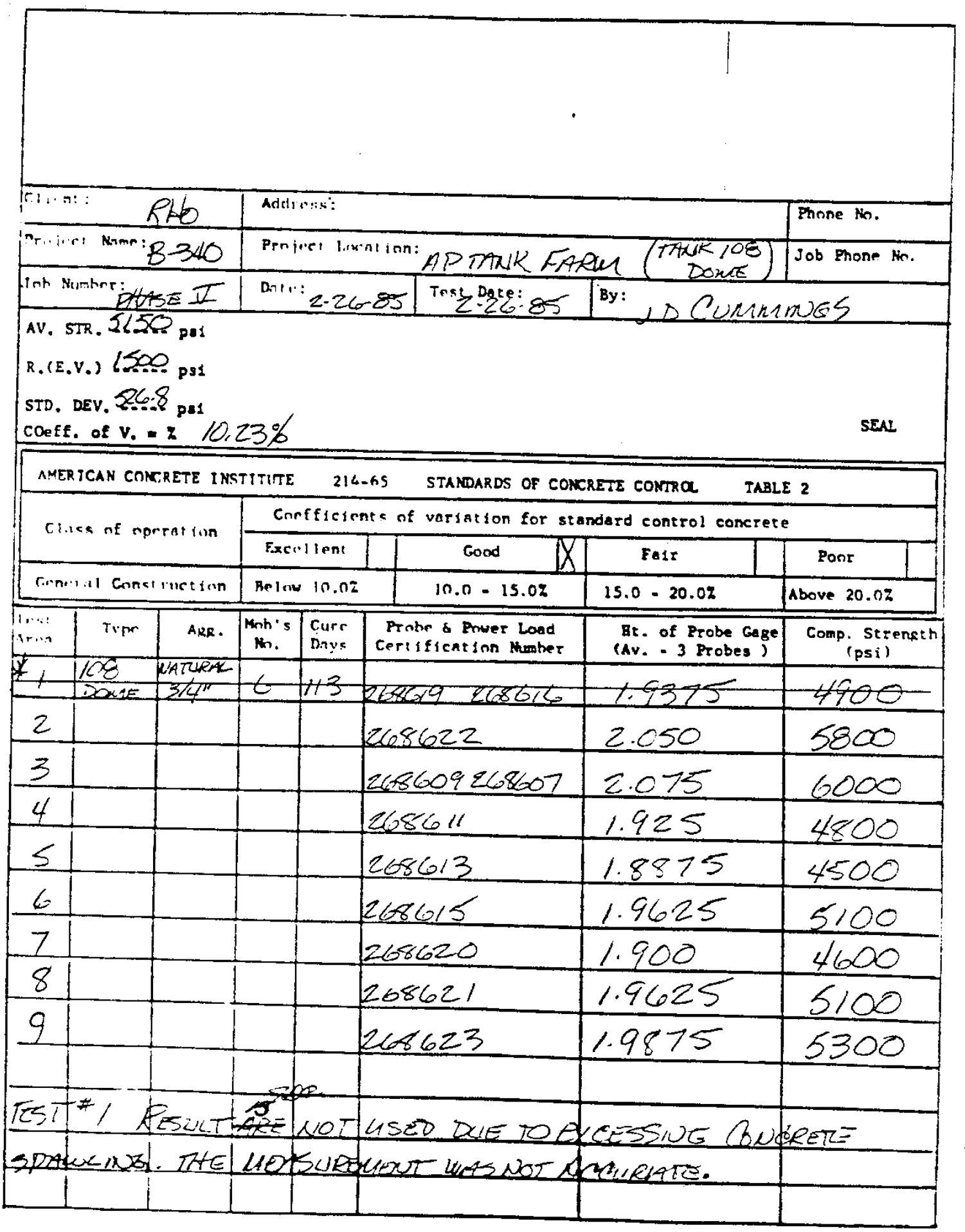


TAEQE 3 - FACTORS FOR COMPUTMG WITHIN TEST STARDARD DEVLATION

\begin{tabular}{|c|c|}
\hline $\begin{array}{l}\text { Wuber of } \\
\text { Spectimens }\end{array}$ & $1 / d_{2}$ \\
\hline $\begin{array}{r}2 \\
3 \\
4 \\
5 \\
6 \\
7 \\
8 \\
9 \\
10\end{array}$ & $\begin{array}{l}0.8865 \\
0.5907 \\
0.4857 \\
0.4299 \\
0.3946 \\
0.3698 \\
0.3512 \\
0.3367 \\
0.3249\end{array}$ \\
\hline
\end{tabular}

- Froo Table B2, "Manual on Quality Control of Materials". ASTM Special Technical

$\begin{array}{ll}\text { Publication No. 15-C. } & 310 \div 504 \\ \text { Nots: Table ma be used to report as any as ten tests. }\end{array}$

AMERICAN CONCRETE INSTITUE

COPT

STANDARD 214-65

TABLE 2 - STAMDARDS OF COKCRETE COMTROL

\begin{tabular}{|c|c|c|c|c|}
\hline \multirow{2}{*}{ Class of operation } & \multicolumn{4}{|c|}{ Coefficient of variation for different control standards } \\
\hline & Excellent & cood & Fatr & Poct \\
\hline $\begin{array}{l}\text { Over-all variation: } \\
\text { General conatruction }\end{array}$ & $\begin{array}{l}\text { Belor } \\
10.0\end{array}$ & $\begin{array}{l}10.0 \text { to } \\
15.0\end{array}$ & $\begin{array}{l}15.0 \text { to } \\
20.0\end{array}$ & $\begin{array}{l}\text { Above } \\
20.0\end{array}$ \\
\hline Laboratory Control & $\begin{array}{c}\text { Belou } \\
5.0\end{array}$ & $\begin{array}{l}5.0 \text { to } \\
7.0\end{array}$ & $\begin{array}{r}7.0 \mathrm{to} \\
10.0\end{array}$ & $\begin{array}{l}\text { Above } \\
10.0\end{array}$ \\
\hline $\begin{array}{l}\text { Within-test varjations: } \\
\text { Field control }\end{array}$ & $\begin{array}{c}\operatorname{Bel} 00 \\
4.0\end{array}$ & $\begin{array}{l}4.0 \text { to } \\
5.0\end{array}$ & $\begin{array}{l}5.0 \text { to } \\
6.0\end{array}$ & $\begin{array}{c}\text { Above } \\
6.0\end{array}$ \\
\hline Laboratory Control & $\begin{array}{l}\text { Bela } \\
3.0\end{array}$ & $\begin{array}{l}3.0 \\
4.0\end{array}$ & $\begin{array}{l}4.0 \text { to } \\
5.0\end{array}$ & $\begin{array}{c}\text { Above } \\
5.0\end{array}$ \\
\hline
\end{tabular}

Note: These standards represent the average for 28 -day cylinders computed froa a lasge number of tests. Different values for otber than average concretes can be
expected. 
$1500-6802-79$

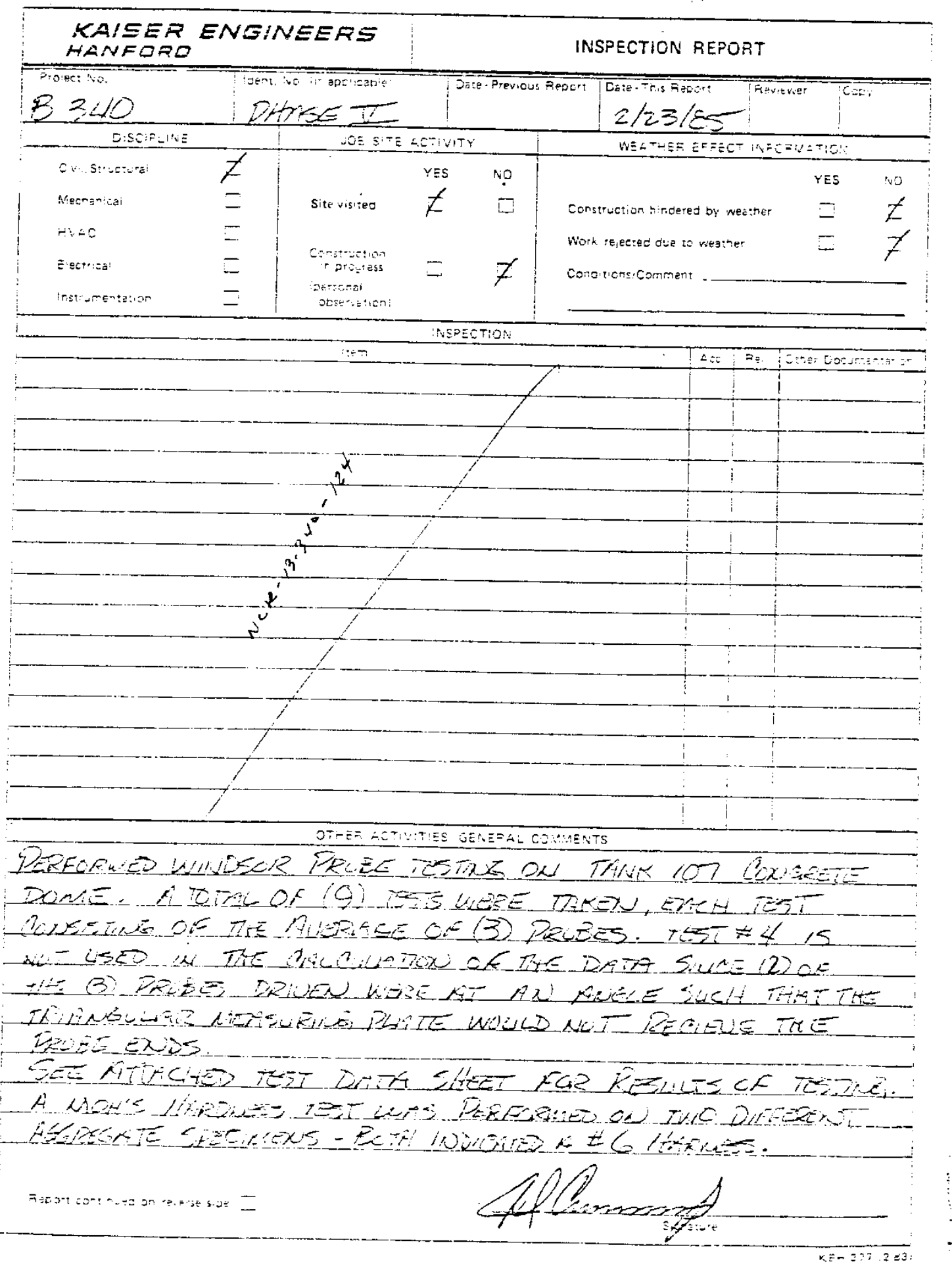


RPP-RPT-55983, Rev. 0

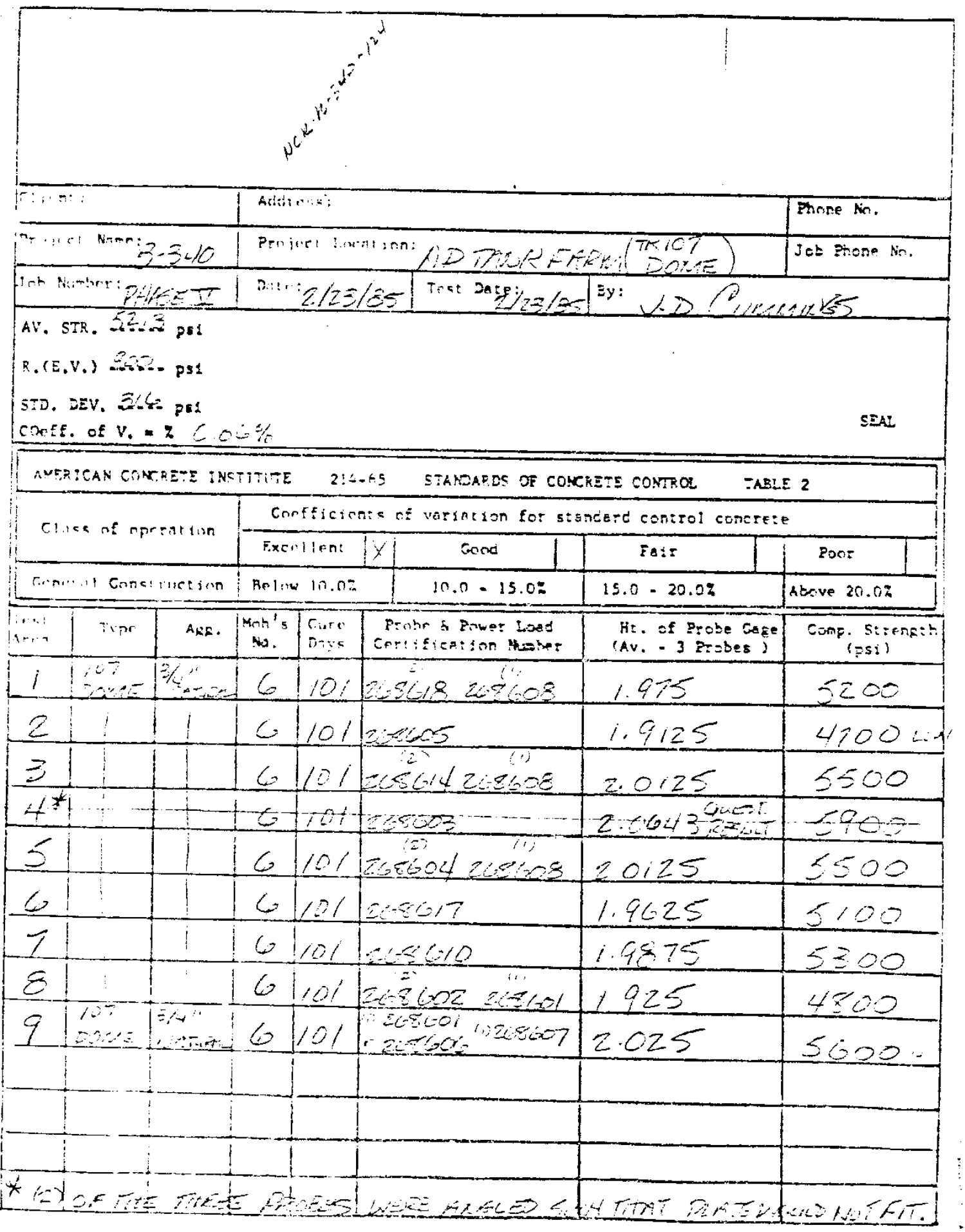


RPP-RPT-55983, Rev. 0

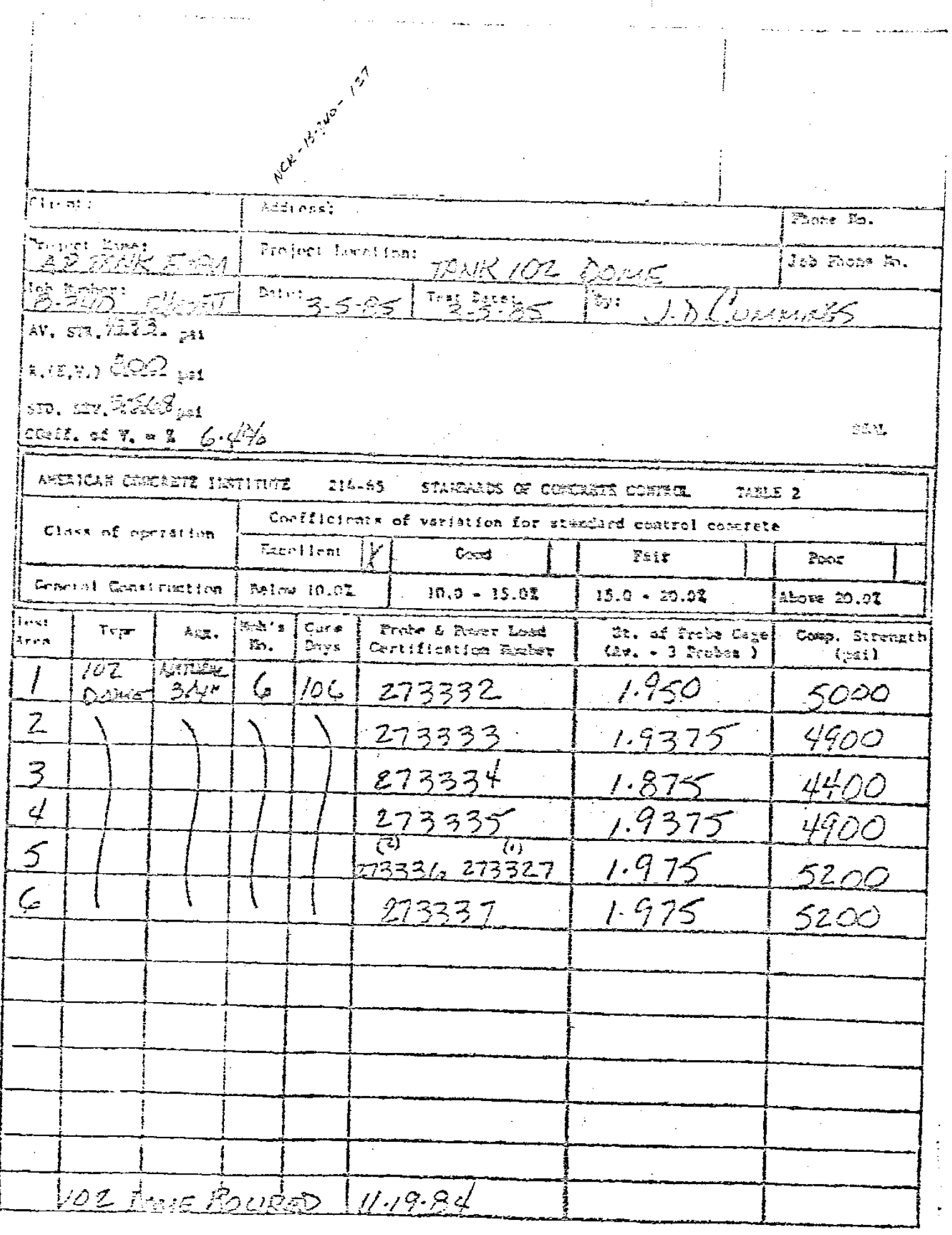


RPP-RPT-55983, Rev. 0

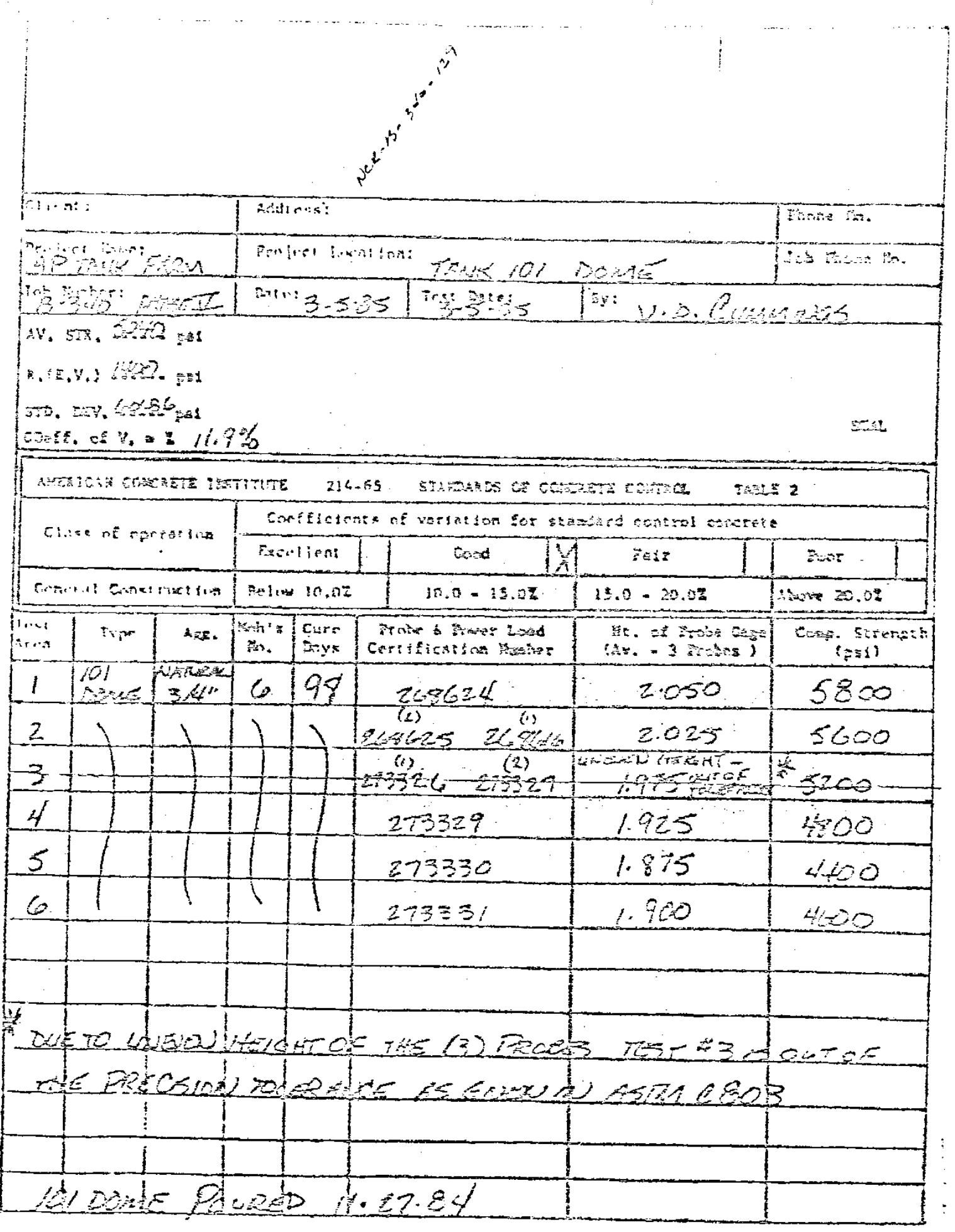


RPP-RPT-55983, Rev. 0

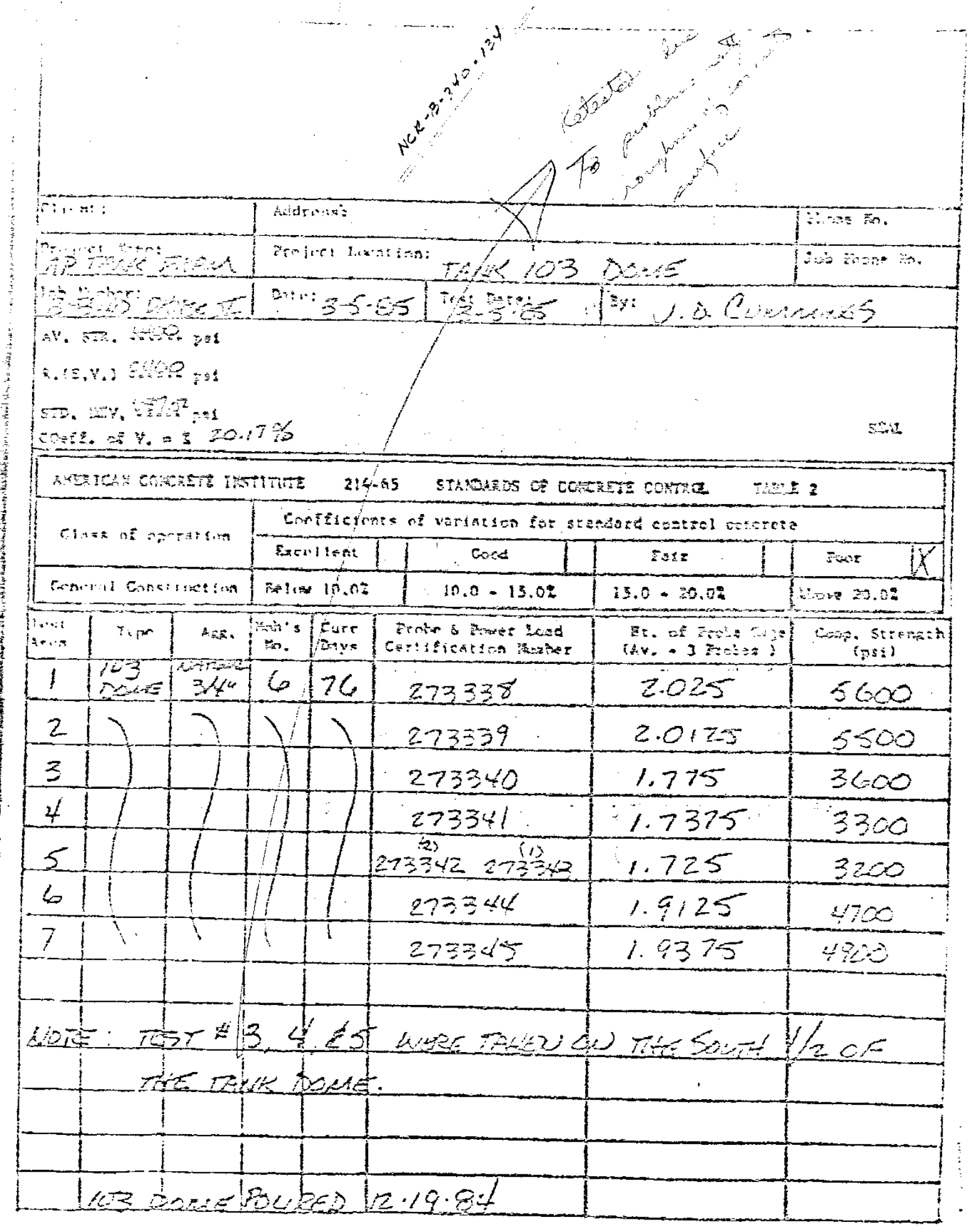


RPP-RPT-55983, Rev. 0

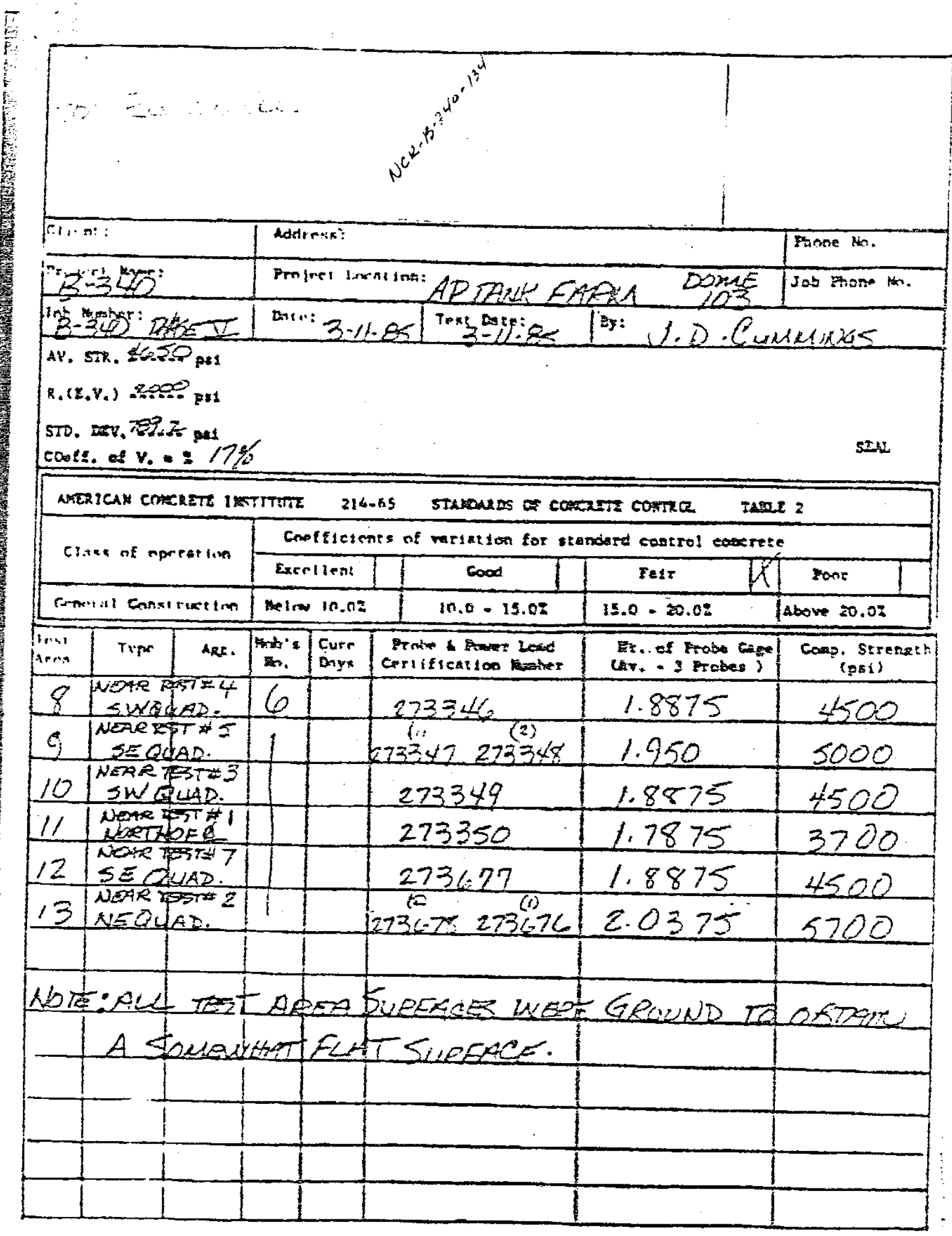


RPP-RPT-55983, Rev. 0

App. Figure B-55. Nonconformance Report B-340-129

AL-604 (2-80)

CONSTRUCTION

(1A.) Project, Location or wo

NONCONFORMANCE REPORT

$B-340$

(ID) Requirement

(1E) Nonconformence Description

REQUIREMENTS

1. A. Specification B-340-C5, Rev. 0, Section 03300, Paragraph 3.7.1. The concrete will be tested to ACI 301, Sections 16.3.4, 16.3.5, 16.3.6, and 16.3.8, and ACI 318, Section

(18) Titt
241-AP TANK FARM (PHASE V)
B-340-C5, Rev. 0, Section 03300, Paragraph
6.3.6, and 16.3.8, and ACI 318, Section
B-340-C5, Rev. 0, Section 03300, Paragraph
allowable compressive strength: 5000 psi

2.1 Specification B-340-C5, Rev. 0, Section 03300, Paragraph at 28 days.

2. ACI 318-77, Section 4.8.3.4. Procedures for protecting and curing concrete shall be improved when the strength of field cured cylinders at the test age designated for measuring specified compressive strength is less than 85 percent of that of companion laboratory-cured cylinders.

(continued)

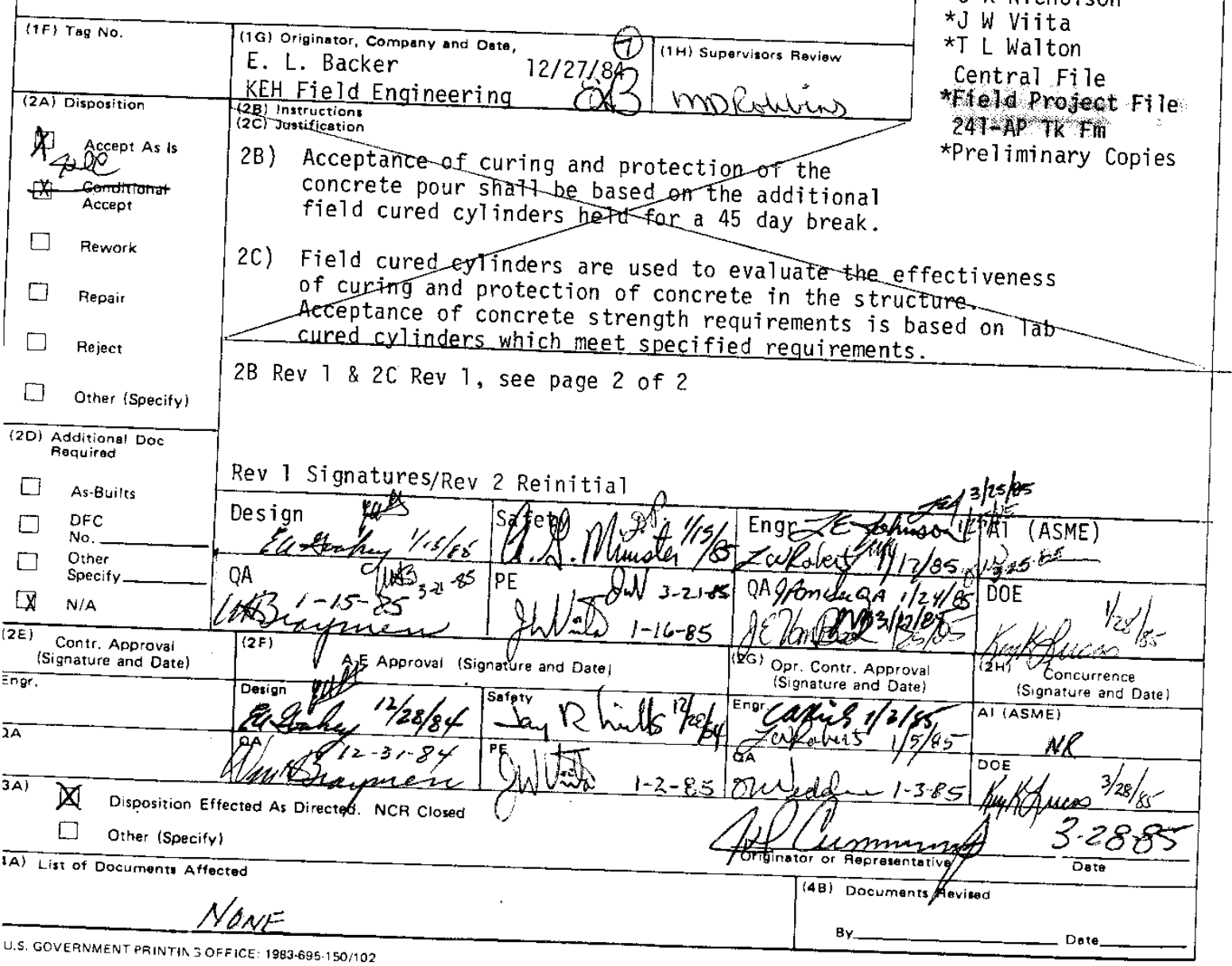


RPP-RPT-55983, Rev. 0

NCR B-340-129 (1520-88)

Page 2 of 2

NONCONFORMANCE DESCRIPTION

Concrete cylinder breaks for Tank 101 Dome area: Field cured cylinders failed to make $5000 \mathrm{psi}$ or $85 \%$ of laboratory-cured cylinders.

Test No.

I.

2.
Cylinder No.

$3199-4 \quad(F C)$

$-5 \quad(F C)$

$-6$

$-7$

$3199-11(F C)$

$-12(\mathrm{FC})$

$-13$

$-14$
PSI 028 Days

4230

4210

$54800.85(5480)=4658$

$53600.85(5360\rangle=4556$

4210

4170

$53900.85(5390)=4582$

$55400.85(5540)=4709$

2B) INSTRUCTIONS Rev 1

Acceptance of curing and protection of the concrete pour shall be based on the results of tests on 45 day field cylinders taken for the dome and/or haunch pours on tanks 103, 104, 105, and 106.

2C) JUSTIFICATION ReV I

Additional cylinders for 45 day strength tests are not available on this

tank for testing. The results of tests on field cured cylinders from other tanks with the same concrete mix, protected by the same methods and exposed to similar weather extremes will verify the concrete will develop the specified strength.

2B) Instruction Rev 2

Accept as is

2C) Justification Rev 2

See attached letter dated $3 / 20 / 85$ by EA Goakey and JW Viita 
RPP-RPT-55983, Rev. 0

\section{KAISER \\ ENGINEERS \\ HANFCRD}

INTEROFFICE MEMORANDUM

ro Distribution
DATE
March 20, 1985
FROM
E. A. Goakey gaty
J. W. Viita gov

JOR NO.

subsect Project B-340, NCR's B-340 - 124, 127, 129 and 134

These NCR's were written because the field cured cylinder breaks did not meet the ACI guideline of being within $85 \%$ of the laboratory cured breaks. Acceptance of the concrete mix is based on the laboratory breaks where the field breaks indicate the acceptability of the curing procedures in place and the effect the weather may have on the in-place concrete.

Acceptance of NCR \#134 per the original disposition was to be based on 45 day cylinder breaks for that pour. Acceptance of the other 3 NCR's was to be sased on 45 day breaks for those pours for which spare cylinders were available week. The results of the 28 day and 45 day field cured cylinder breaks are summarized
as follows:

$\begin{array}{cl}\text { Tank } 103 \text { Dome } & \text { Pour S1 ip \# } \\ 104 \text { Dome } & 3207 \\ 105 \text { Dome } & 3204 \\ 106 \text { Dome } & 3202 \\ 106 \text { Haunch } & 3200 \\ 104 \text { Haunch } & 3203 \\ 103 \text { Haunch } & 3205 \\ \text { 105 Haunch } & 3206\end{array}$

28 day F.C.
4308 psi
4710
4720
4960
5342
4278
4560
5090

45 day F.C. $4 T 98$ psi 4905

4408

4832

5660

4725

3206

5042

5110

Average $\quad 4746 \mathrm{psi} \quad 4860 \mathrm{psi}$

The average 28 day Field Cured cylinder breaks for the pours with the open NCR's is:

\begin{tabular}{|c|c|c|}
\hline $\begin{array}{l}107 \text { Dome } \\
102 \text { Dome } \\
101 \text { Dome } \\
103 \text { Dome }\end{array}$ & $\begin{array}{l}\frac{\text { NCR }}{124} \# \\
127 \\
129 \\
134\end{array}$ & $\begin{array}{l}\frac{28 \text { day } F . C .}{3458 \text { psi }} \\
4020 \\
4205 \\
4308\end{array}$ \\
\hline
\end{tabular}

$$
\text { Average } \quad 3998 \mathrm{psi}
$$

The specified concrete strength is 5000 psi for laboratory cured cylinders at 28 days. Using $85 \%$ for field cured cylinders would give us a value of 4250 psi for field cured cylinders. The average strength gain demonstrated by the 45 day cylinder breaks was lower than expected and does not give a firm indication that the field strength would meet the 4250 psi figure but does show that the concrete is continuing to gain strength despite the prolonged period of cold weather. 
RPP-RPT-55983, Rev. 0

Interoffice Memorandum

March 20, 1985

There are some notable inconsistancies in the test data such as the decrease in strength from 28 day field cure to 45 day field cure for 3 of the 8 pours for which 45 day field breaks are available. Due to these inconsistancies, it was decided to perform some tests on the in-place concrete with the Windsor Probe.

The Windsor Probe is approved for use by ASTM in comparing the relative strengths of concrete but not in determining the actual strength. To obtain a comparison to concrete which is known to be acceptable, testing was done on the Tank 108 dome in addition to the 4 domes with open NCR's. The Tank 108 dome had an of $6325 \mathrm{psi}$.

A predicted field cure strength of the concrete was obtained by comparing the Windsor Probe results for Tank 108 and the other domes with the field cure strength
for Tank 108. The following formula was used:

Probe resuits Tank "X" $\quad X \quad 4890$ psi $\quad$ Probe results Tank 708 Predicted Field Cure Strength

Windsor Probe results for Tank 108 indicated an average strength of 5150psi

(8 tests) (concrete age of 113 days)

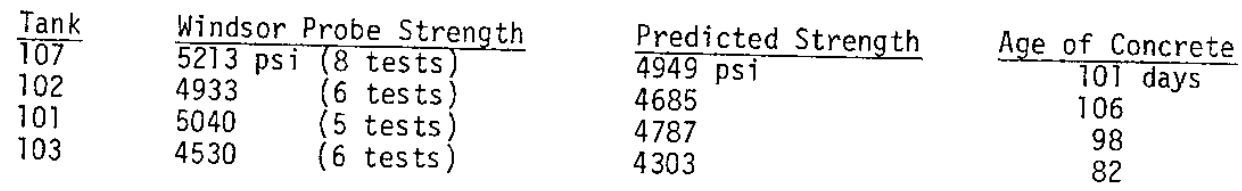

(Tank 103 was tested twice. There were problems with the roughness of the concrete surface possibly effecting the results of the test so the first test was discarded; the test locations were ground to an acceptable smoothness (a) lowed by ASTM) and new tests performed.)

The results indicate predicted field cure strength in excess of 4250 psi with an actual increase of essentially zero (0) (4303 versus 4308 ) for the Tank 103 field approximately 1500 psi for the Tank 107 dome when compared to the field cured cylinder results. These predicted strengths are considered somewhat conservative since the base results from Tank 108 have the longest cure time with Tank 103 having 31 days less cure time.

In sumary, considering the Windsor Probe results on the in-place concrete along with the cylinder test results (both lab. cured and field cured) all encasement concrete will develop the required strength to properly perform as intended in the design. Some of the individual tests may indicate a problem but the overal results indicate that the contractor has mapplied JWV/ss

Distribution: Attachment to NCR B-340-124

Attachment to NCR B-340-127

Attachment to NCR B-340-129

Attachment to NCR B-340-134

EA Goakey

JW Vijta File

Central File

LB 
RPP-RPT-55983, Rev. 0

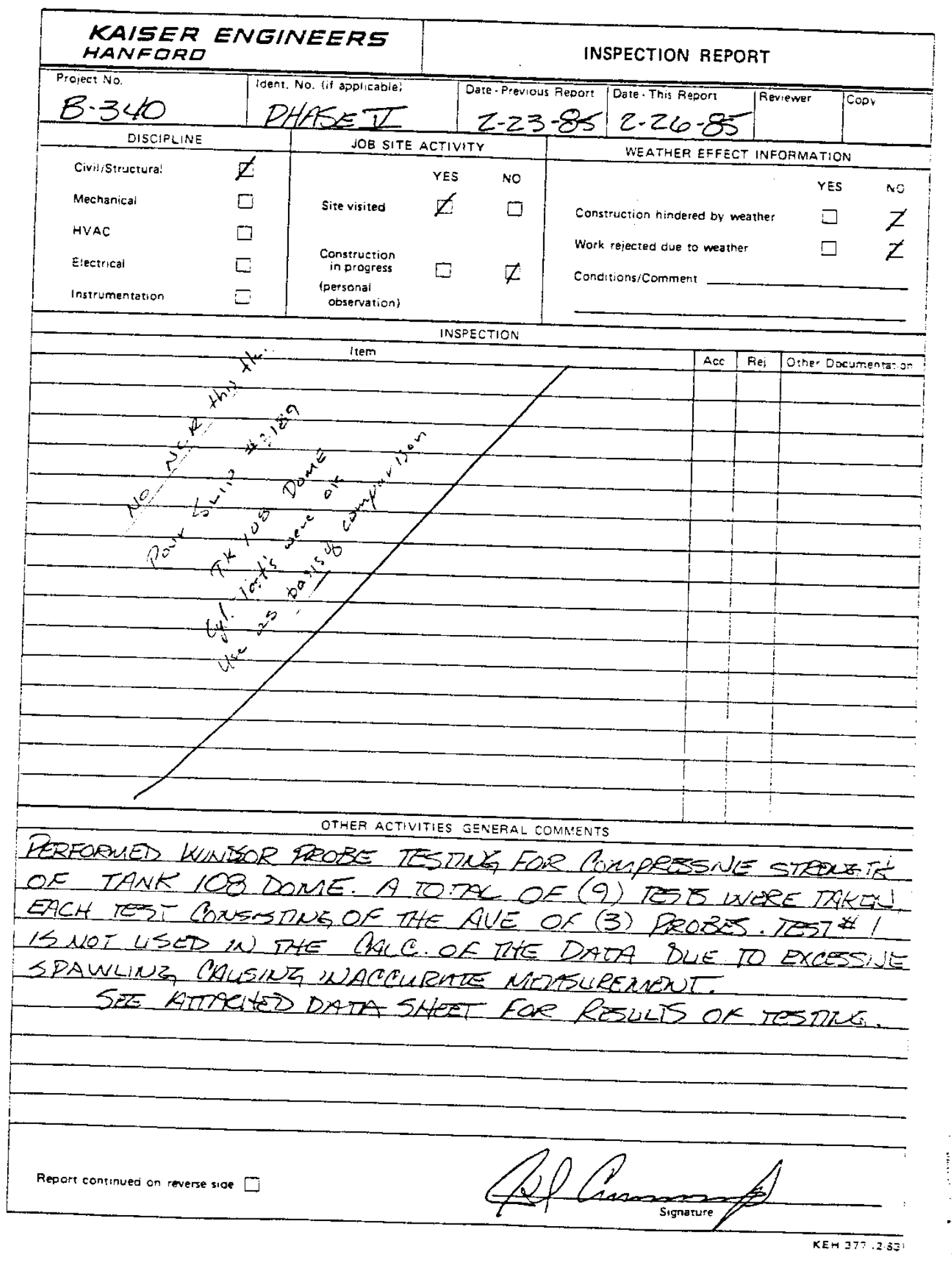


RPP-RPT-55983, Rev. 0

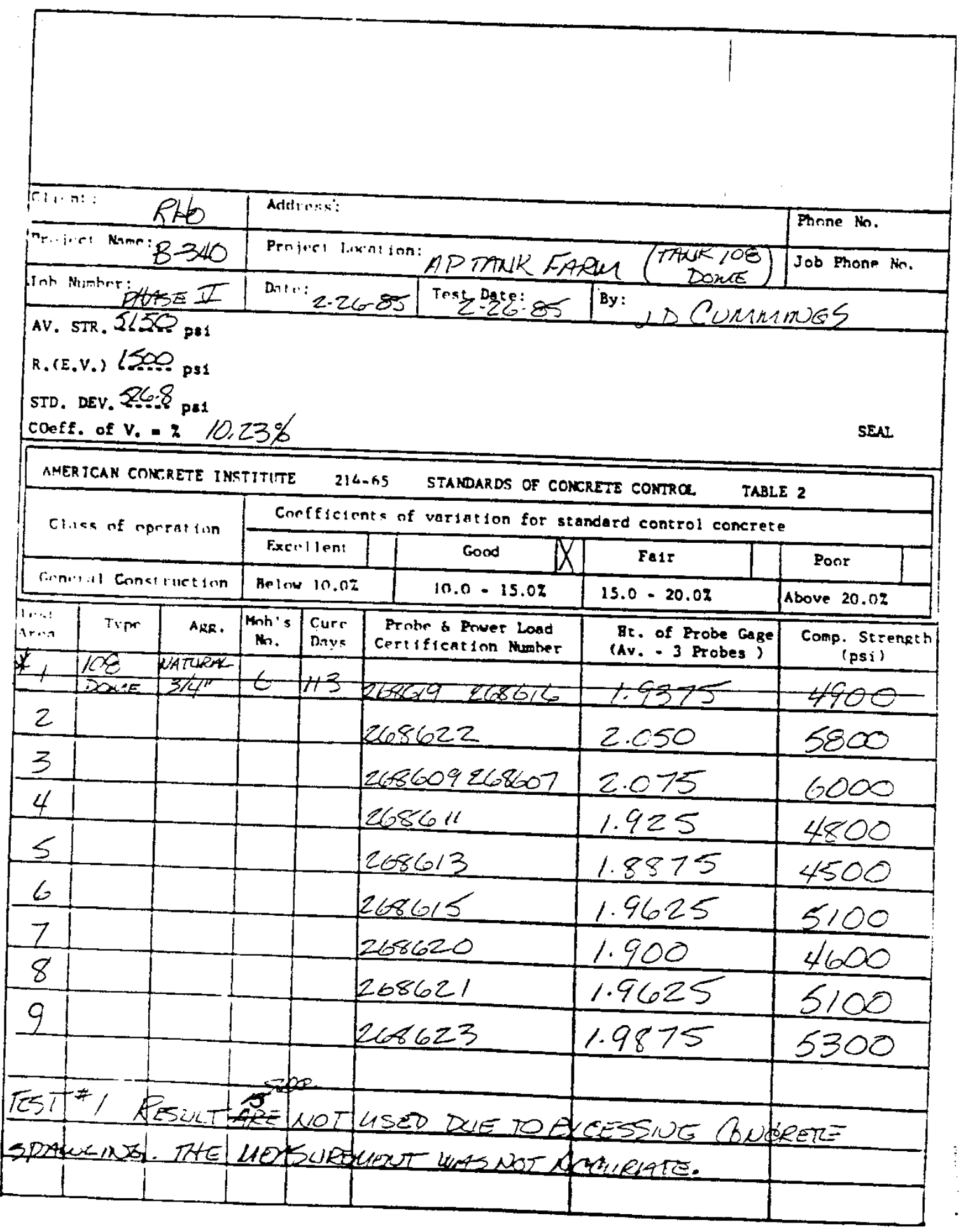


IABE 3 - FACTORS FOR COMPUTING WITHIN-TEST STANDARD DEVIATION

\begin{tabular}{|c|c|c|}
\hline $\begin{array}{c}\text { miber of } \\
\text { Speciens }\end{array}$ & & $1 / d_{2}$ \\
\hline 2 & & 0.8865 \\
3 & & 0.5907 \\
4 & 0.4857 \\
5 & & 0.4299 \\
7 & & 0.3946 \\
8 & & 0.3698 \\
9 & & 0.3512 \\
10 & & 0.3367 \\
\hline
\end{tabular}

* Froo Table B2, "Manual on Quality Control of Materials", ASTM Special Technical Publication No. 15-C.

NOTE: Table ma be used to report as many as ten tests.

ANIRICAN CONCRETE INSTITUE $\operatorname{cop}$

TABLE 2 - STANEARDS OP CONCRETE COMTROA

\begin{tabular}{|c|c|c|c|c|}
\hline \multirow{2}{*}{ Class of operation } & \multicolumn{4}{|c|}{ Coefficlent of variation for different control standards } \\
\hline & Excellent & Cood & Fa15 & Poc: \\
\hline $\begin{array}{l}\text { Qver-all variation: } \\
\text { General construction }\end{array}$ & $\begin{array}{l}\text { Belou } \\
10.0\end{array}$ & $\begin{array}{l}10.0 \text { to } \\
15.0\end{array}$ & $\begin{array}{l}15.0 \text { to } \\
20.0\end{array}$ & $\begin{array}{l}\text { Above } \\
20.0\end{array}$ \\
\hline Leboratory Control & $\begin{array}{l}\text { Below } \\
5.0\end{array}$ & $\begin{array}{l}5.0 \text { to } \\
7.0\end{array}$ & $\begin{array}{l}7.0 \text { to } \\
10.0\end{array}$ & $\begin{array}{l}\text { Above } \\
10.0\end{array}$ \\
\hline $\begin{array}{l}\text { Within-test variations: } \\
\text { Fleld control }\end{array}$ & $\begin{array}{c}\operatorname{Bel} 10 \\
4.0\end{array}$ & $\begin{array}{l}6.0 \text { to } \\
5.0\end{array}$ & $\begin{array}{l}5.0 \text { to } \\
6.0\end{array}$ & $\begin{array}{c}\text { Above } \\
6.0\end{array}$ \\
\hline Laboratory Control & $\begin{array}{c}\text { Below } \\
3.0\end{array}$ & $\begin{array}{l}3.020 \\
4.0\end{array}$ & $\begin{array}{l}4.0 \text { to } \\
5.0\end{array}$ & $\begin{array}{c}\text { Above } \\
5.0\end{array}$ \\
\hline
\end{tabular}

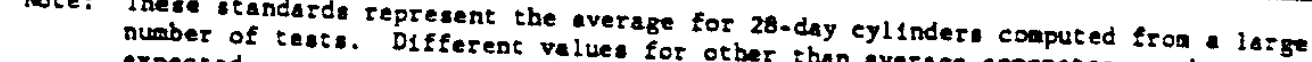
expected.
Astune Hoh's 44 Aggregate

Exposed Arobe Height

1.800 10eh $\quad 1.750$ inch C
pei comer 1.825 inch 5100 psi windsor colum $¥ 4$

Std. Dev. = Range $\times \underline{0.5907}$. (Eroo Iable 3)

Thus: $525 \times .5907=310$ (Std. Dev, )

Coeff. of Var. = Std. Dev. : Av. pai $\times 100$ or

$310 \div 5041$ (av.) $=.614 \times 100=6.142$
USIX TABhs 3 (2x. 3 test repor:) 
RPP-RPT-55983, Rev. 0

전 $<805-7 \Rightarrow$

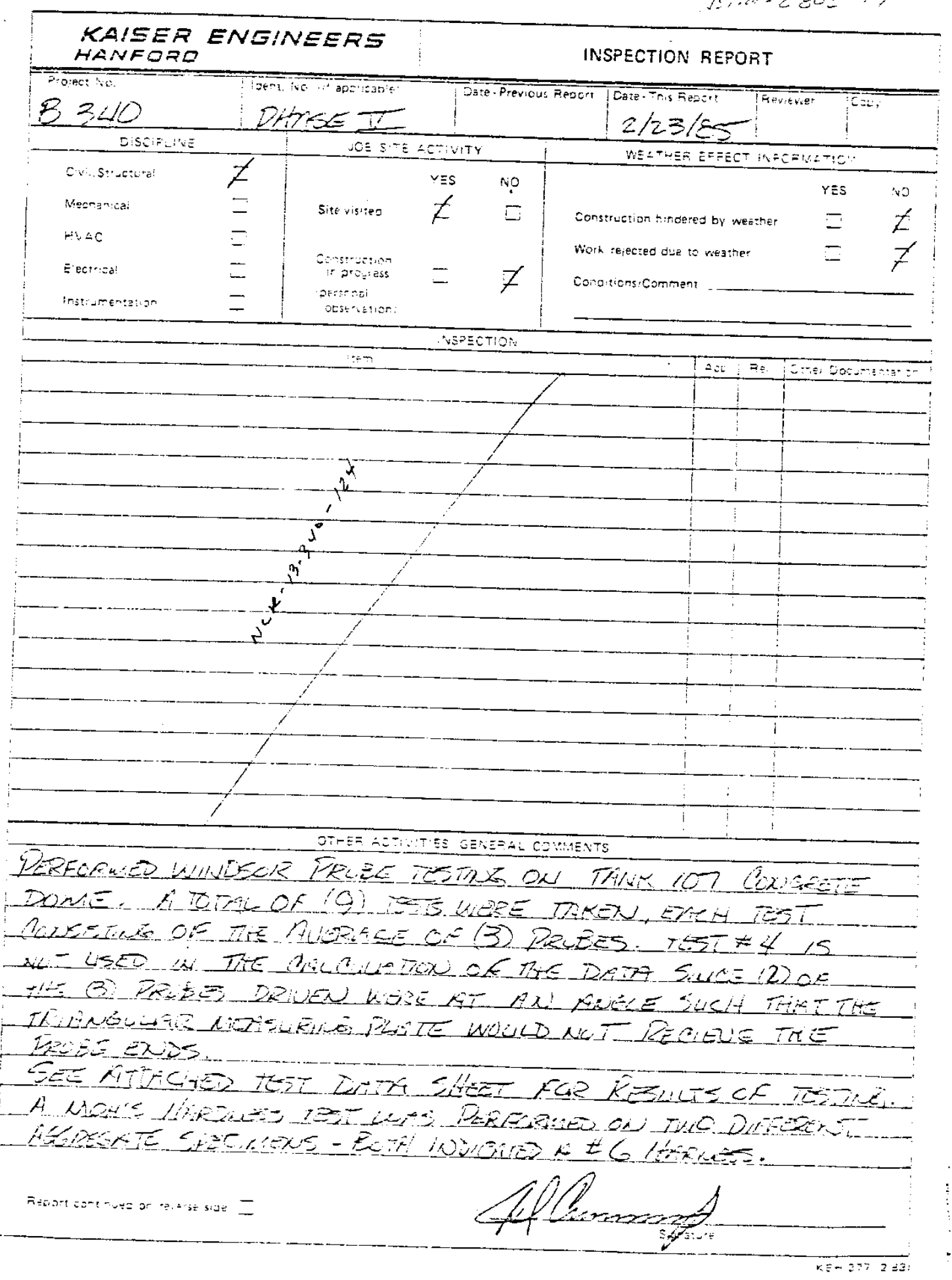


RPP-RPT-55983, Rev. 0

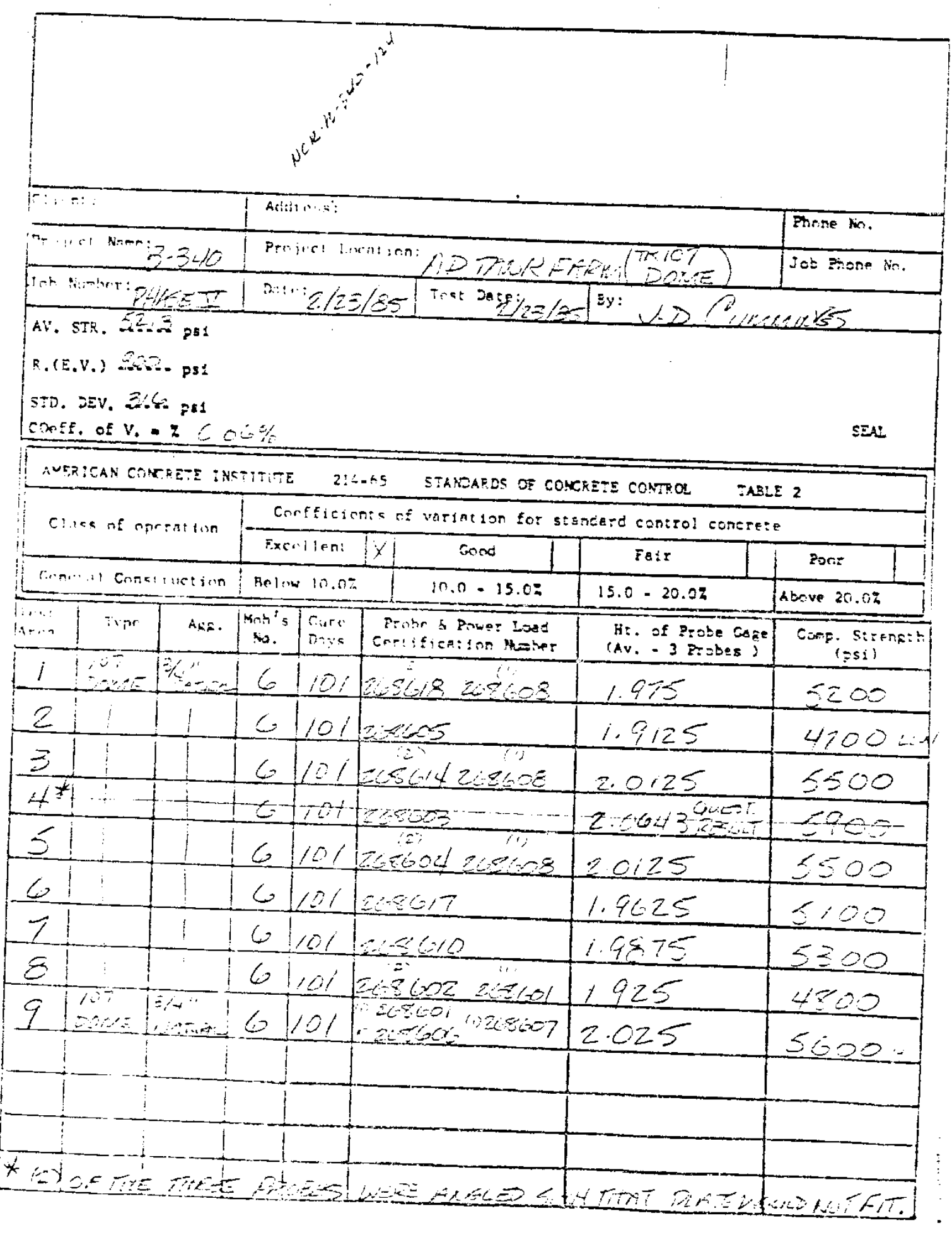


RPP-RPT-55983, Rev. 0

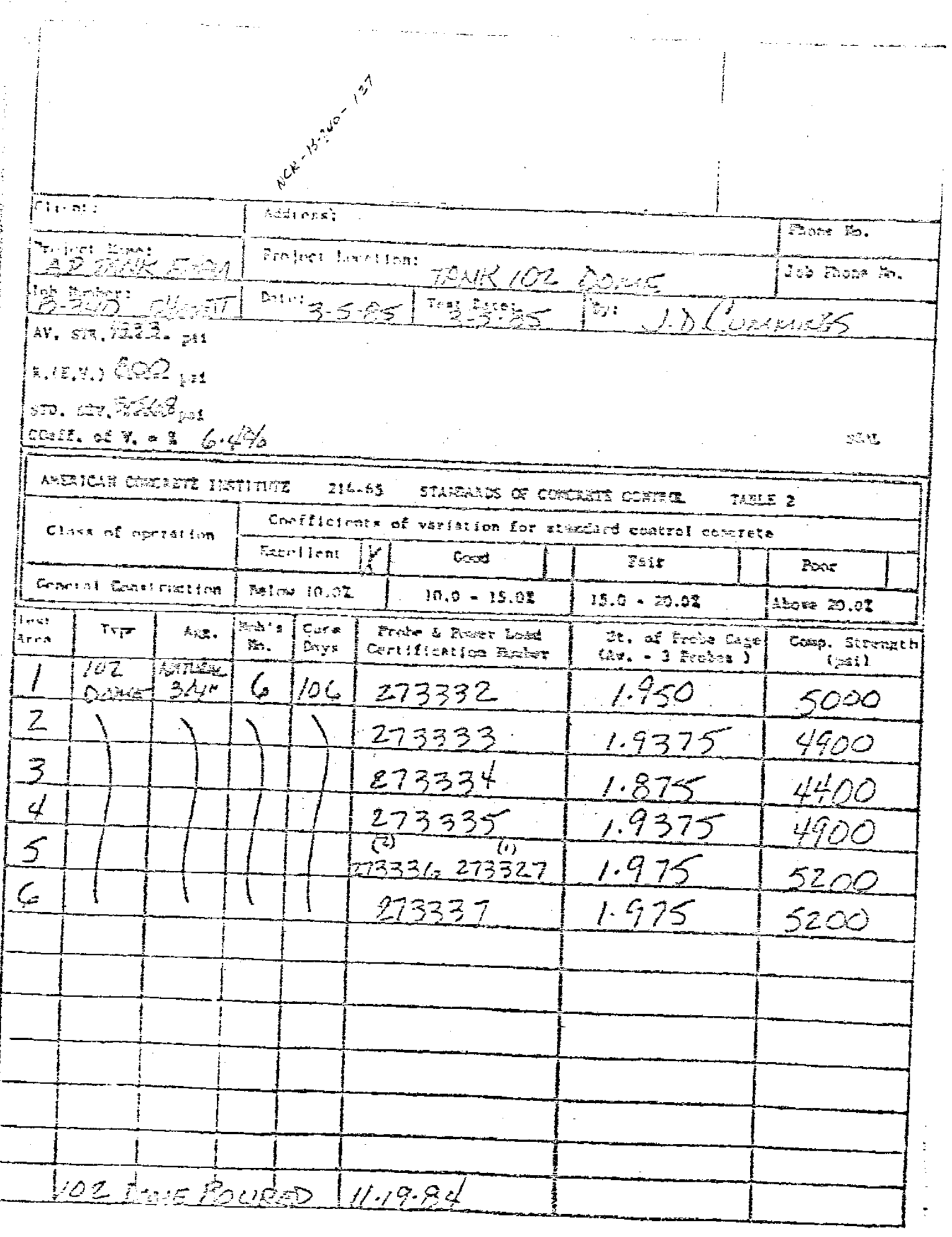


RPP-RPT-55983, Rev. 0

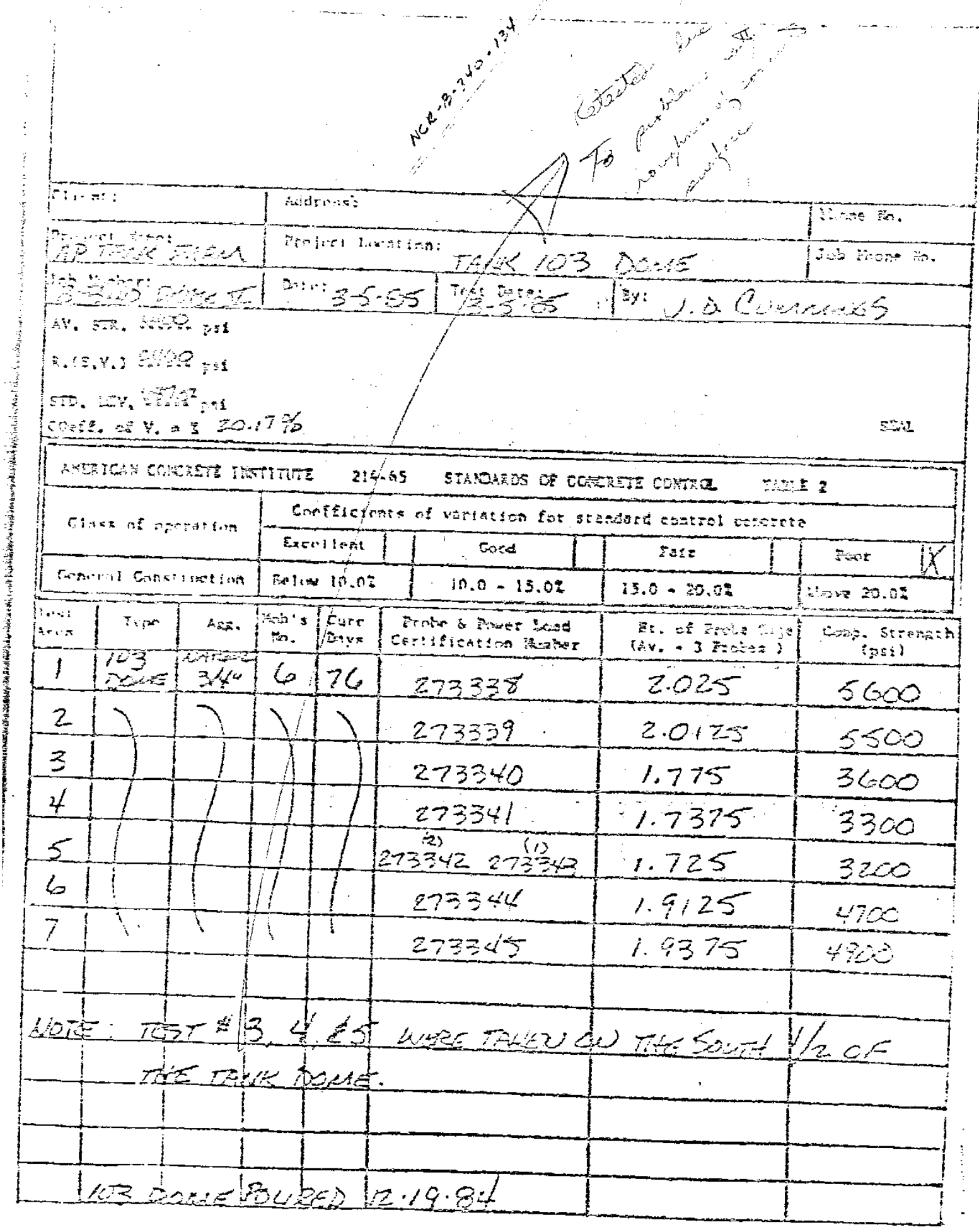


RPP-RPT-55983, Rev. 0

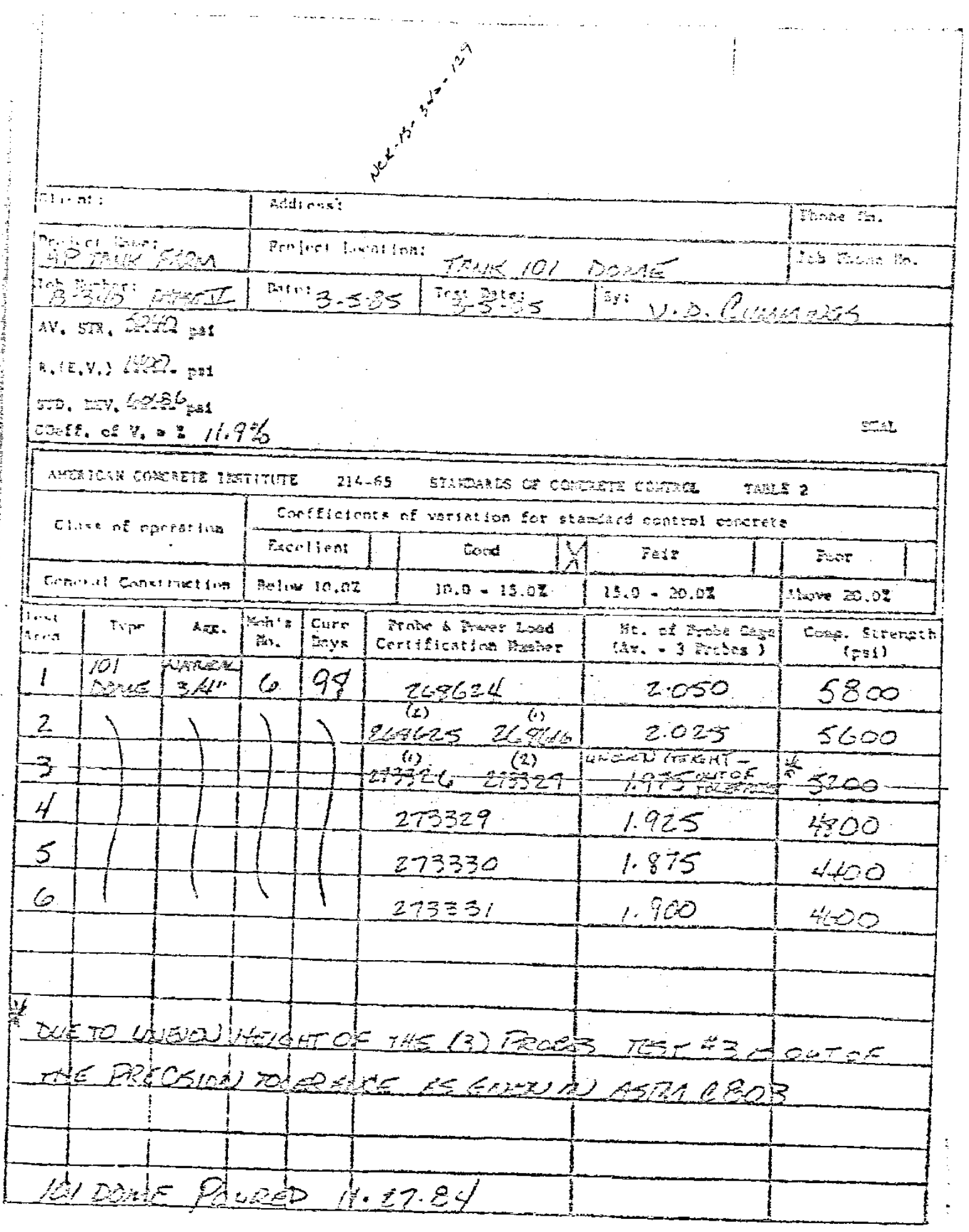


RPP-RPT-55983, Rev. 0

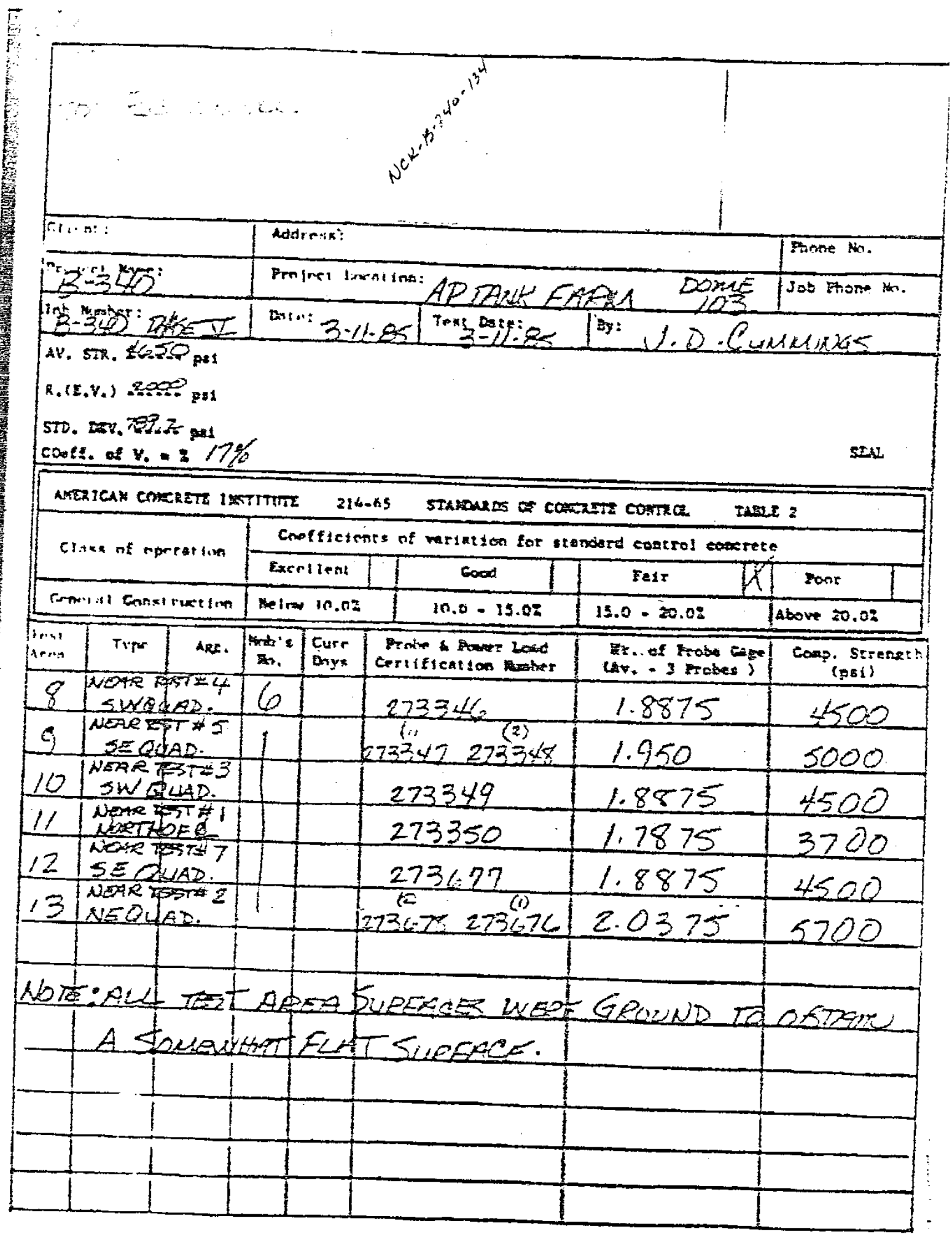


RPP-RPT-55983, Rev. 0

App. Figure B-56. Nonconformance Report B-340-130

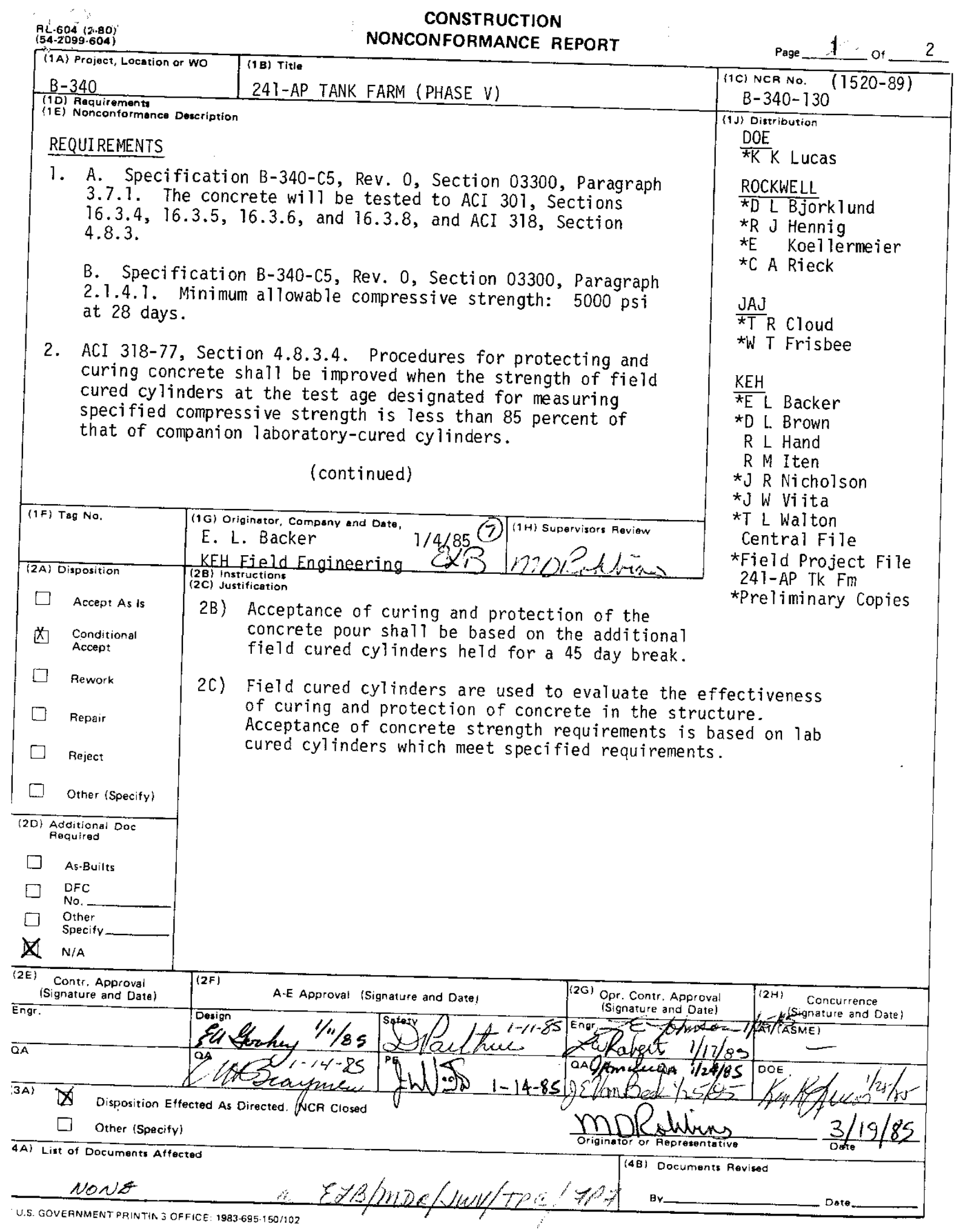


RPP-RPT-55983, Rev. 0

NCR B-340-130 (1520-89)

Page 2 of 2

Concrete cylinder breaks for Tank 104 Haunch area: field cured cylinders failed to make 5000 psi or $85 \%$ of laboratory-cured cylinders.

Test No.

3
Cylinder No.

$3203-23$ (FC)

$\begin{array}{ll}-24 & (F C) \\ -25 & \end{array}$

$-26$
PSI a 28 Days

4050

3990

$53400.85(5340)=4539$

$52000.85(5200)=4420$ 


\section{KAISER \\ ENGINEERS \\ HANFORD \\ INTEROFFICE MEMORANDUM}

To Distribution below

COPIES TO
date March 18, 1985
rrom E. A. Goakey que

JOอ NO.

SUBJECt B-340 241-AP TANK FARM NCR B-340-130

A total of three (3) pairs of field cured and three (3) pairs of laboratory cured cylinders were tested at twenty-eight (28) days and forty-five (45) days for the concrete in question on NCR B-340-130.

The following summarizes the results:

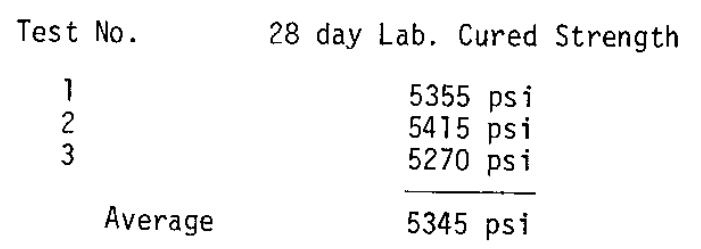

Test No.

45 day Lab. Cured Strength

1
2
3

Average

Increase in Average Strength 28 day to 45 day

$$
\begin{array}{r}
6150 \mathrm{psi} \\
6000 \mathrm{psi} \\
5510 \mathrm{psi} \\
\hline 5885 \mathrm{psi} \\
\frac{\text { Lab. Cured }}{540 \mathrm{psi}}
\end{array}
$$

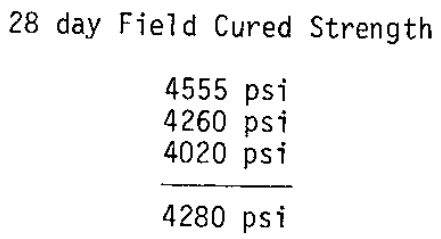

45 day Field Cured Strength

$$
\begin{aligned}
& 4865 \text { psi } \\
& 4730 \text { ps } \\
& 4580 \text { psi } \\
& \hline 4725 \text { psi }
\end{aligned}
$$

Field Cured

445 psi

The gain in strength of $445 \mathrm{ps} i$ from the 28 day to the 45 day field cured breaks provides assurance that the curing of the concrete was continuing despite the extended period of cold weather. The in place concrete would be better protected due to the increased mass of the haunch area and based on engineering judgement would have an in place strength in excess of 5000 psi.

$E A G / s S$

Distribution: Attachment to NCR B-340-130

J. W. Viita

Central File

E. A. Goakey File

LB 
RPP-RPT-55983, Rev. 0

App. Figure B-57. Nonconformance Report B-340-132

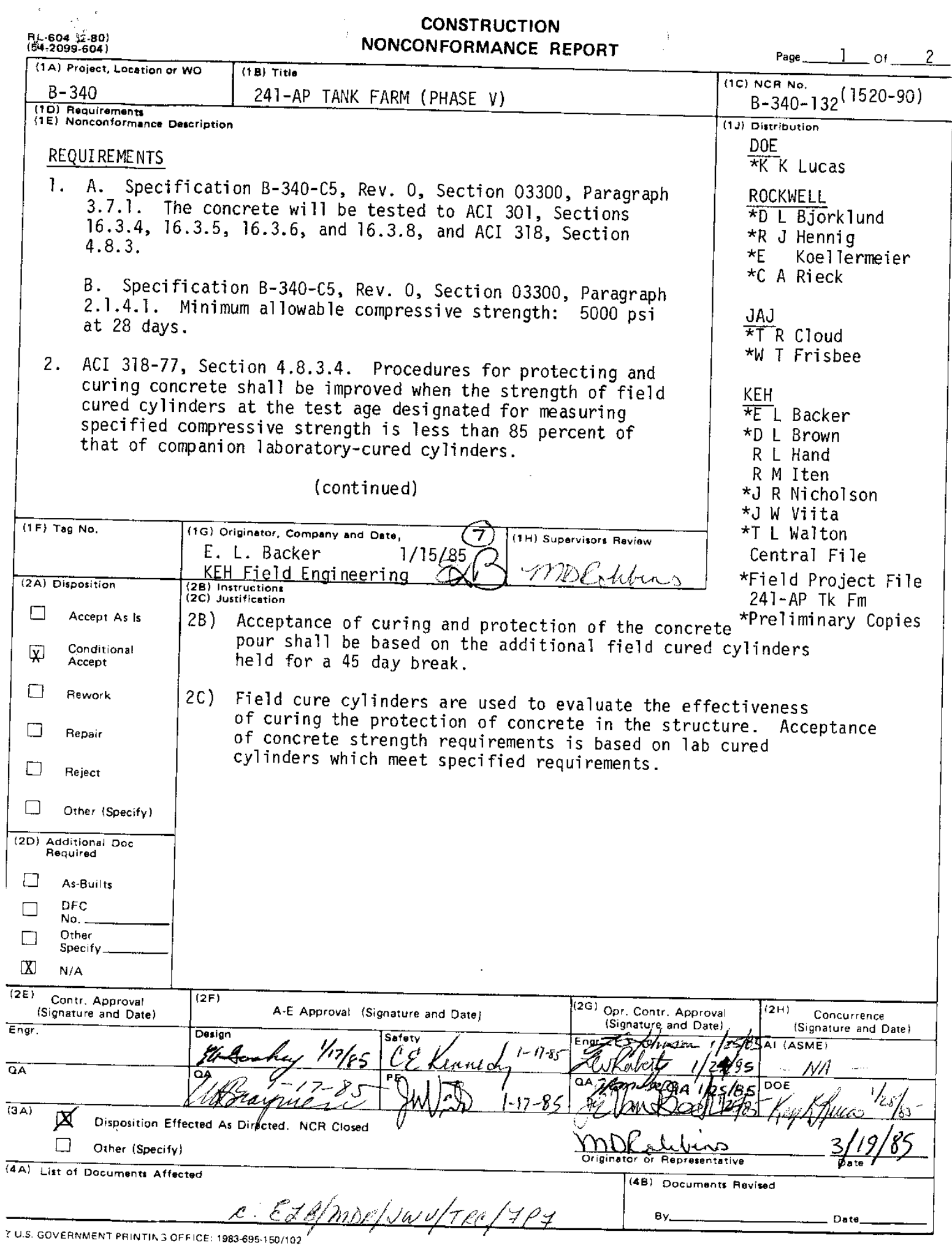


RPP-RPT-55983, Rev. 0

B-340-132 (1520-90)

Page 2 of 2

Field cured cylinders for the Tank 103 Haunch Area failed to make 5000 psi or $85 \%$ of the laboratory-cured cylinders.

Test №.

1.
Cylinder No.

$3205-23 \quad(F C)$

-24 (FC)
PSI 028 Days

4160

4170

$55700.85(5570)=4735$

$53000.85(5300)=4505$ 
RPP-RPT-55983, Rev. 0

\section{KAISER \\ ENGINEERS HANFORD \\ INTEROFFICE MEMORANDUM

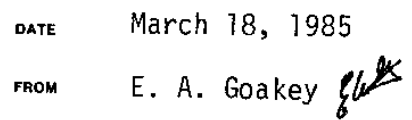

то Distribution below
JOB No.

\footnotetext{
subJect Project B-340 241-AP TANK FARM NCR B-340-132

A total of three (3) pairs of Taboratory cured and three (3) pair of fjeld cured cylinders were tested at twenty-eight (28) days and forty-five (45) days for the concrete in question on NCR-B-340-132. The results are summarized as follows:

Test No.

1

2

3

Average

Test No.

]

2

3

Average

Increase in Average Strength 28 days to 45 days

28 day Lab. Cured Strength

5290 psi

6200 psi

5435 psi

5640 psi

45 day Lab. Cured Strength

5785 psi

6660 psi

5555 psi

6000 psi

Lab. Cured

360 psi

28 day Field Cured Strength

4435 psi

5080 psi

4165 psi

4560 psi

45 day Field Cured Strength

4825 psi

5605 psi

4955 psi

5130 psi

Field Cured

570 ps $i$

The gain in strength of 570 psi from the twenty-eight (28) day to forty-five

(45) day field cured breaks provides assurance that the curing of the concrete was continuing despite the extended period of cold weather. The forty-five (45)

day average field cured strenth of 5130 is greater than the minimum design strength of $5000 \mathrm{psi}$.

$E A G / s S$

Distribution: Attachment to NCR B-340-132

J. W. Viita

Central File

E. A. Goakey File

LB
}

DOE. A Chland. WA 
RPP-RPT-55983, Rev. 0

App. Figure B-58. Nonconformance Report B-340-134

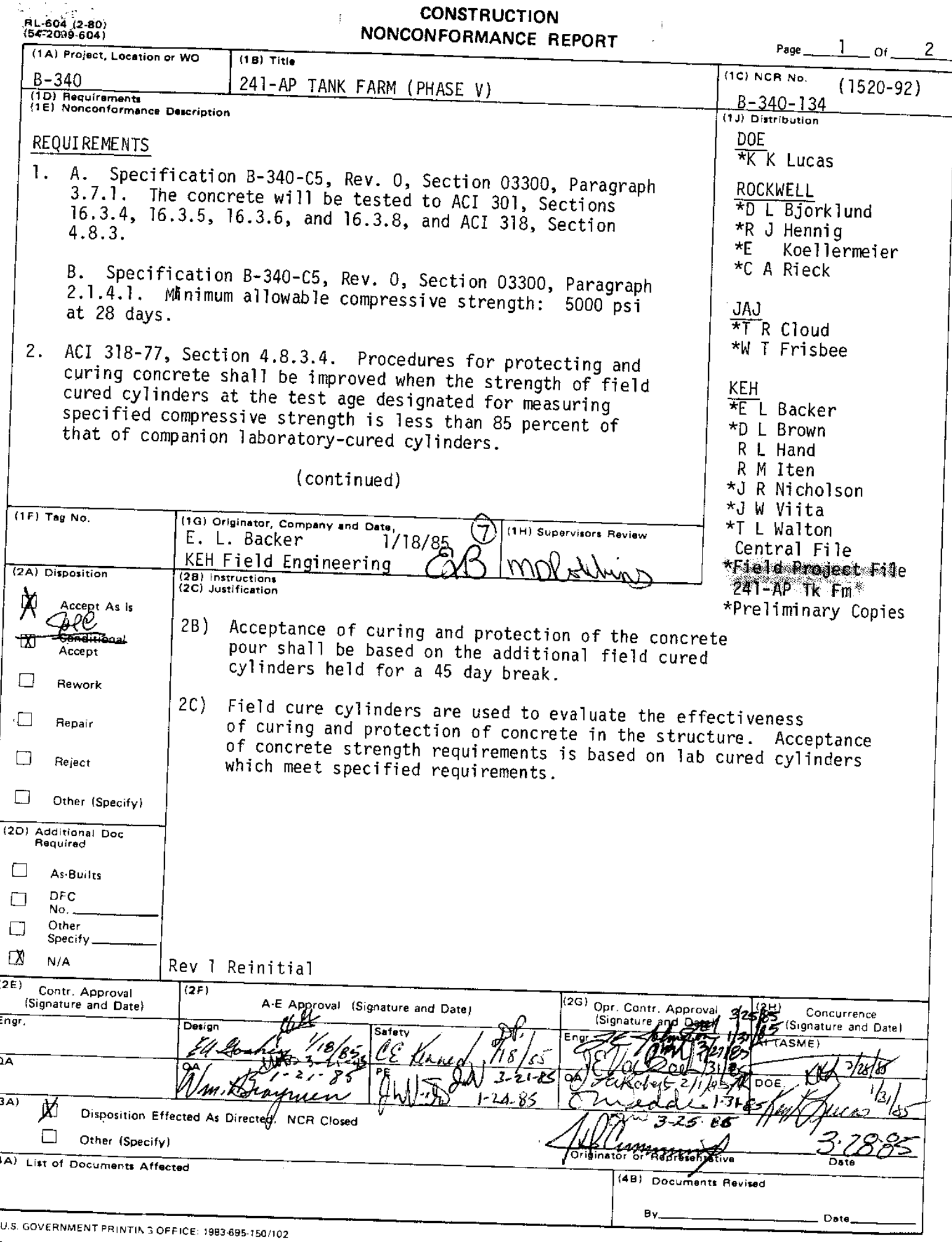


RPP-RPT-55983, Rev. 0

NCR B-340-134 (1520-92)

Page 2 of 2

Tank 103 Dome concrete cylinder breaks at 28 days: field cured cylinders fajled to make 5000 psi or $85 \%$ of laboratory-cured cylinders.

Test No.

Cylinder No.

PSI \& 28 Days

1.

$\begin{array}{rr}3207-4 & (F C) \\ -5 & (F C) \\ -6 & \\ -7 & \end{array}$

4080

4320

$52300.85(5230)=4446$

$50100.85(5010)=4256$

2B) Instructions Rev 1

Accept as is

2C) Justification Rev 1

See attached letter dated $3 / 20 / 85$ by EA Goakey and JW Viita 


\section{KAISER \\ ENGINEERS HANFORD \\ INTEROFFICE MEMORANDUM}

ro

Distribution

COPIES TO

Date March 20, 1985
ERom A. Goakey
J. W. Viita gN

JOB NO.

subaect Project B-340, NCR's B-340 - 124, 127, 129 and 134

These NCR's were written because the field

the ACI guideline of being within $85 \%$ of the cured cylinder breaks did not meet of the concrete mix is based on the laboratory aboratory cured breaks. Acceptance indicate the acceptability of the curing procedures where the field breaks the weather may have on the in-place concrete. Acceptance of NCR \#134 per the original disposit

cylinder breaks for that pour. Acceptanisposition was to be based on 45 day based on 45 day breaks for those pours since all curing blankets and heat were removed frome cylinders were available week. The results of the 28 day and 45 day field cured cylinder breaks are summarized
as follows:

$\begin{array}{cc}\text { Tank } 103 \text { Dome } & \text { Pour Slip \# } \\ 104 \text { Dome } & 3207 \\ 105 \text { Dome } & 3208 \\ 106 \text { Dome } & 3202 \\ 106 \text { Haunch } & 3200 \\ 104 \text { Haunch } & 3203 \\ 103 \text { Haunch } & 3205 \\ 105 \text { Haunch } & 3206\end{array}$

Average

28 day F.C.

4308 psi $^{-}$

4710

4720

4960

5342

4278

4560

5090

4746 psi
45 day F.C. 4798 psi

4905

4408

4832

5660

4725

5042

5110

4860 psi

The a verage 28 day Field Cured cylinder breaks for the pours with the open
NCR's is:

\begin{tabular}{|c|c|c|}
\hline $\begin{array}{l}107 \text { Dome } \\
102 \text { Dome } \\
101 \text { Dome } \\
103 \text { Dome }\end{array}$ & $\begin{array}{l}\frac{N C R}{124} \# \\
127 \\
129 \\
134\end{array}$ & $\begin{array}{l}\frac{28}{3458} \text { day F.C. } \\
4020 \\
4205 \\
4308\end{array}$ \\
\hline & Average & 3998 psi \\
\hline
\end{tabular}

The specified concrete strength is 5000 psi for laboratory cured cylinders for field 45 fayd cured cylinders. The average strength gain 45 day cylinder breaks was lower than strength gain demonstrated by the indication that the field strength would meet and does not give a firm show that the concrete is continuing to gain the $4250 \mathrm{psi}$ figure but does period of cold weather. 
RPP-RPT-55983, Rev. 0

Interoffice Memorandum

March 20, 1985

There are some notable inconsistancies in the test data such as the decrease for which 45 day 28 day field cure to 45 day field cure for 3 of the 8 pours for which 45 day field breaks are available. Due to these inconsistancies, Windsor Probe.

The Windsor Probe is approved for use by ASTM in comparing the relative strengths of concrete but not in determining the actual strength. To obtain a comparison to concrete which is known to be acceptable, testing was done on the Tank 108 average 28 day field cure strength open NCR's. The Tank 108 dome had an of 6325 psi.

a laboratory cure strength

A predicted field cure strength of the concrete was obtained by comparing the Windsor Probe results for Tank 108 and the other domes with the field cure strength
for Tank 108. The following formula was used:

Probe results Tank "X" $\quad X \quad 4890$ psi $\quad=\quad$ Predicted Field Cure Strength

Windsor Probe results for Tank 108 indicated an average strength of 5150psi

(8 tests) (concrete age of 113 days)

Tank Windsor Probe Strength

\begin{tabular}{|c|c|c|c|c|}
\hline $\begin{array}{l}\frac{\operatorname{lank}}{107} \\
102 \\
101 \\
103\end{array}$ & $\begin{array}{l}\text { Windsor } \\
52 \bar{T} 3 \text { psi } \\
4933 \\
5040 \\
4530\end{array}$ & $\begin{array}{l}\text { Probe Strer } \\
(8 \text { tests) } \\
(6 \text { tests) } \\
(5 \text { tests }) \\
(6 \text { tests) }\end{array}$ & $\begin{array}{l}\text { Predicted Strengt } \\
4949 \text { psi } \\
4685 \\
4787 \\
4303\end{array}$ & 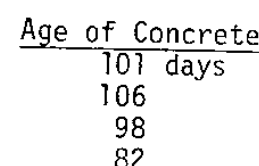 \\
\hline
\end{tabular}

(Tank 103 was tested twice. There were problems with the roughness of the was discarded; the possibly effecting the results of the test so the first test (allowed by ASTM) and new tests performed.)

The results indicate predicted field cure strength in excess of 4250 psi with an actual increase of essentially zero (0) (4303 versus 4308 ) for the Tank 103 field cured cylinder results. 1500 psi for the Tank 107 dome when compared to the somewhat conservative since the These predicted strengths are considered cure time with Tank 103 having 31 days 7 iss from Tank 108 have the longest In summary, considering the windsor Probe results on the

In summary, considering the Windsor Probe results on the in-place concrete along with the cylinder test results (both lab. cured and field cured) all encasement the design. Some of the required strength to properly perform as intended in results indicate that the contractor tests may indicate a problem but the overali JWV/ss

Distribution: Attachment to NCR B-340-I24

Attachment to NCR B-340-127

Attachment to NCR B-340-129

Attachment to NCR B-340-134

EA Goakey

JW Vita File

Central File

LB 
RPP-RPT-55983, Rev. 0

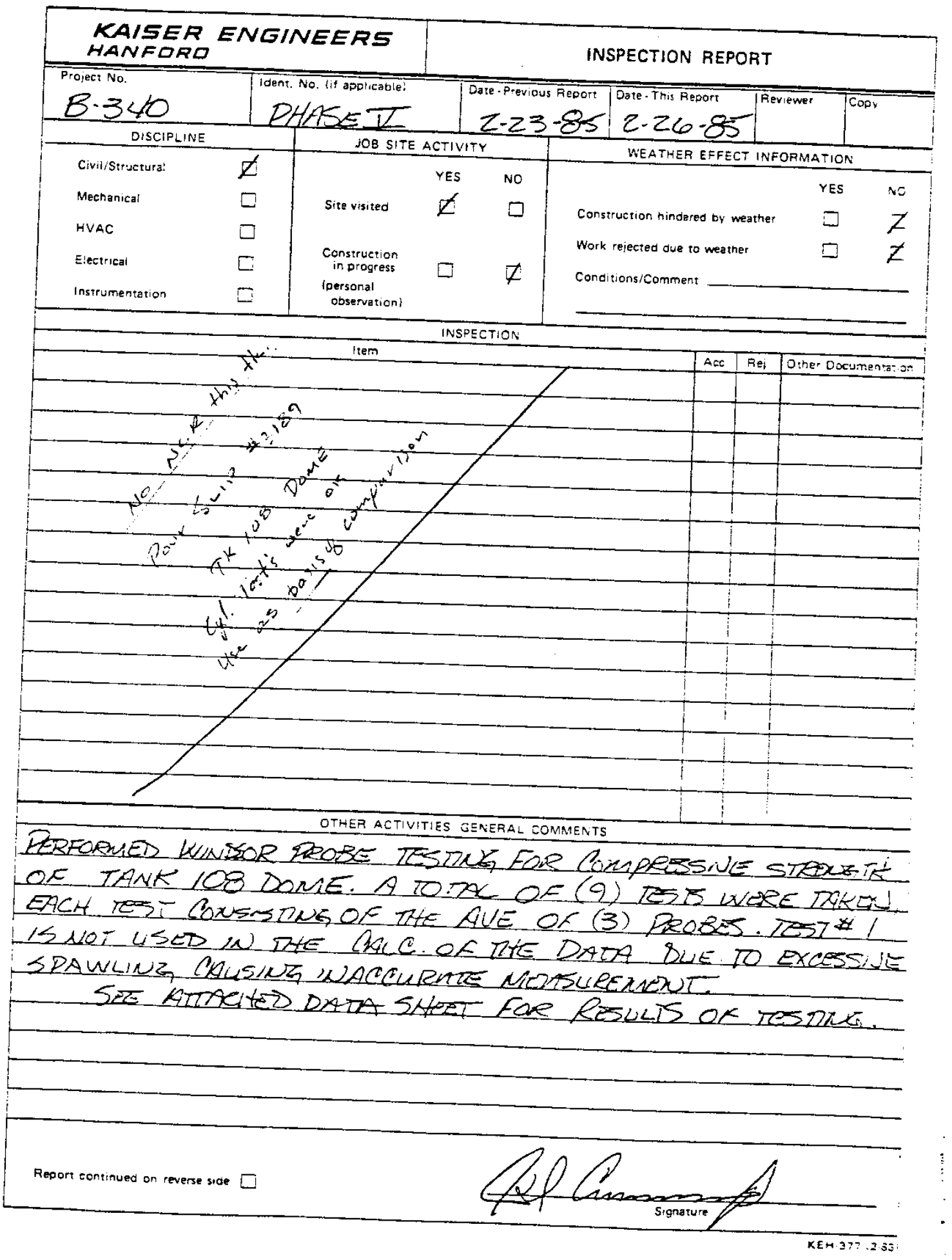


RPP-RPT-55983, Rev. 0

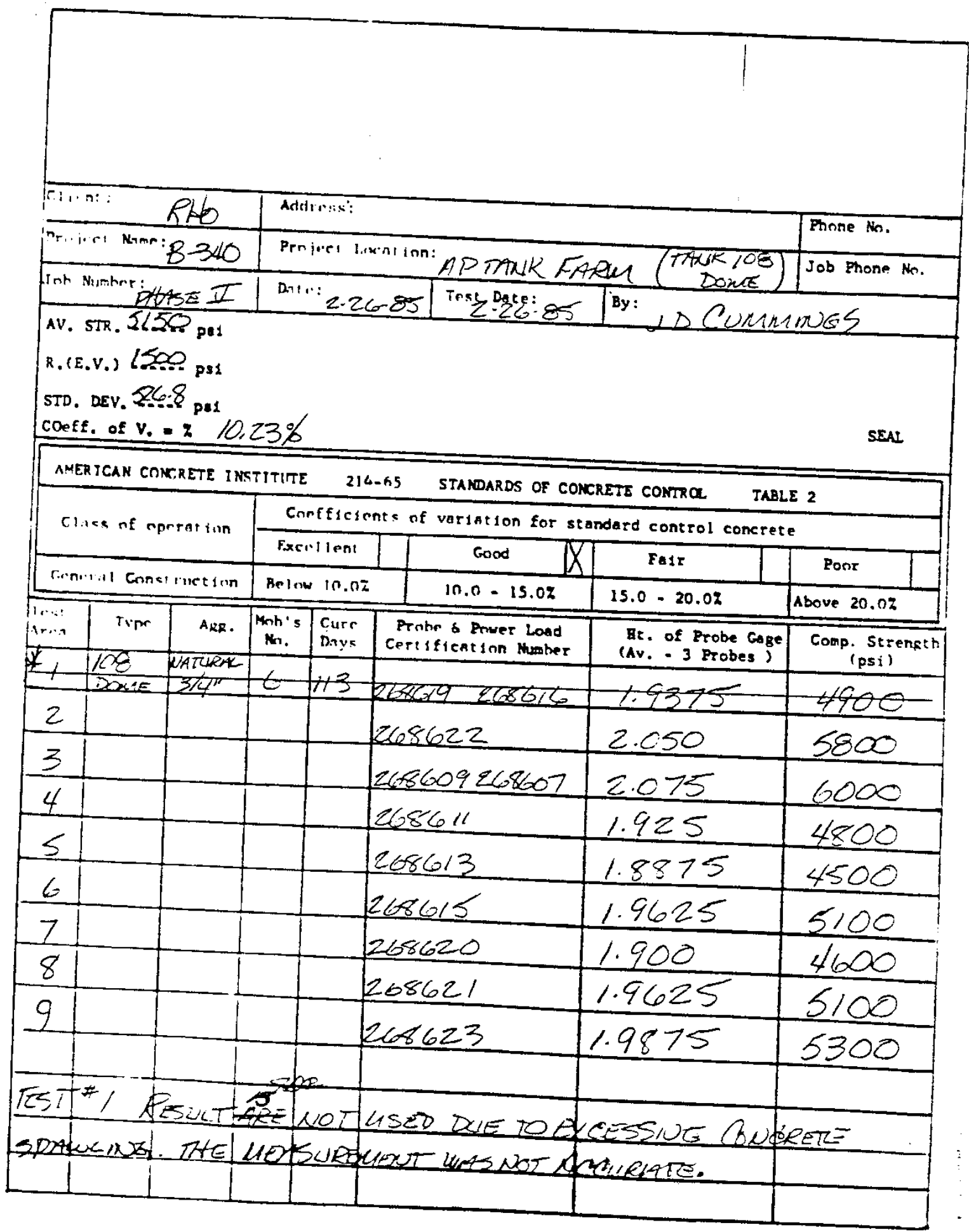


TABLE 3 - FACTORS FOR COMPUTIIG WITHIK TEST STANDARD DEVIATION

\begin{tabular}{|c|c|c|}
\hline $\begin{array}{c}\text { inerer of } \\
\text { Specimens }\end{array}$ & & $1 / d_{2}$ \\
\hline 2 & & 0.8865 \\
3 & & 0.5907 \\
4 & 0.4857 \\
5 & & 0.4299 \\
6 & & 0.3946 \\
7 & & 0.3698 \\
8 & & 0.3512 \\
9 & & 0.3367 \\
10 & & 0.3249 \\
\hline
\end{tabular}

* Froo Table B2, "Manual on Qualfty Control of Materials", ASM Special Technical Publication No. 15-C.

NOTE: Table may be used to report as any as ten tests.

AMERICAN CONCRETE INSTITUE $\underline{\operatorname{CORP}}$

TABLE 2 - STATOURDS OF CONCRETE CONTROL

\begin{tabular}{|l|c|c|c|c|}
\hline \multirow{2}{*}{ Class of operation } & \multicolumn{3}{|c|}{ Coeffictent of variation for different control standarss } \\
\cline { 2 - 5 } & Excellent & Cood & Fait & Poct \\
\hline Over-all variation: & Belor & 10.0 to & 15.0 to & Above \\
General construction & 10.0 & 15.0 & 20.0 & 20.0 \\
Laboratory Control & Bela & 5.0 to & 7.0 to & Above \\
& 5.0 & 7.0 & 10.0 & 10.0 \\
Within-test variations: & Below & 4.0 to & 5.0 to & Above \\
Field control & 4.0 & 5.0 & 6.0 & 6.0 \\
Laboratory Control & Below & 3.0 to & 4.0 to & Above \\
& 3.0 & 4.0 & 5.0 & 5.0 \\
\hline
\end{tabular}

number of tests. Different valuea for other eys cyllnders computed from a large expected.
USING IABLI 3 (24. 3 test reper:)

Alsure Hob's $\$ 4$ Aggregate

Exposed Probe Helght

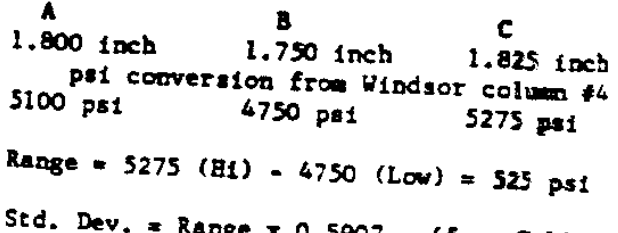

Thus: $525 \times .5907=310$ (Std. Dev.)

Coeff. of Var. - Std. Dev. : Av. par $\times 100$ or

$310 \div 5041$ (av.) $=.614 \times 100=6.14$ 
IS $00-600=-7 y$

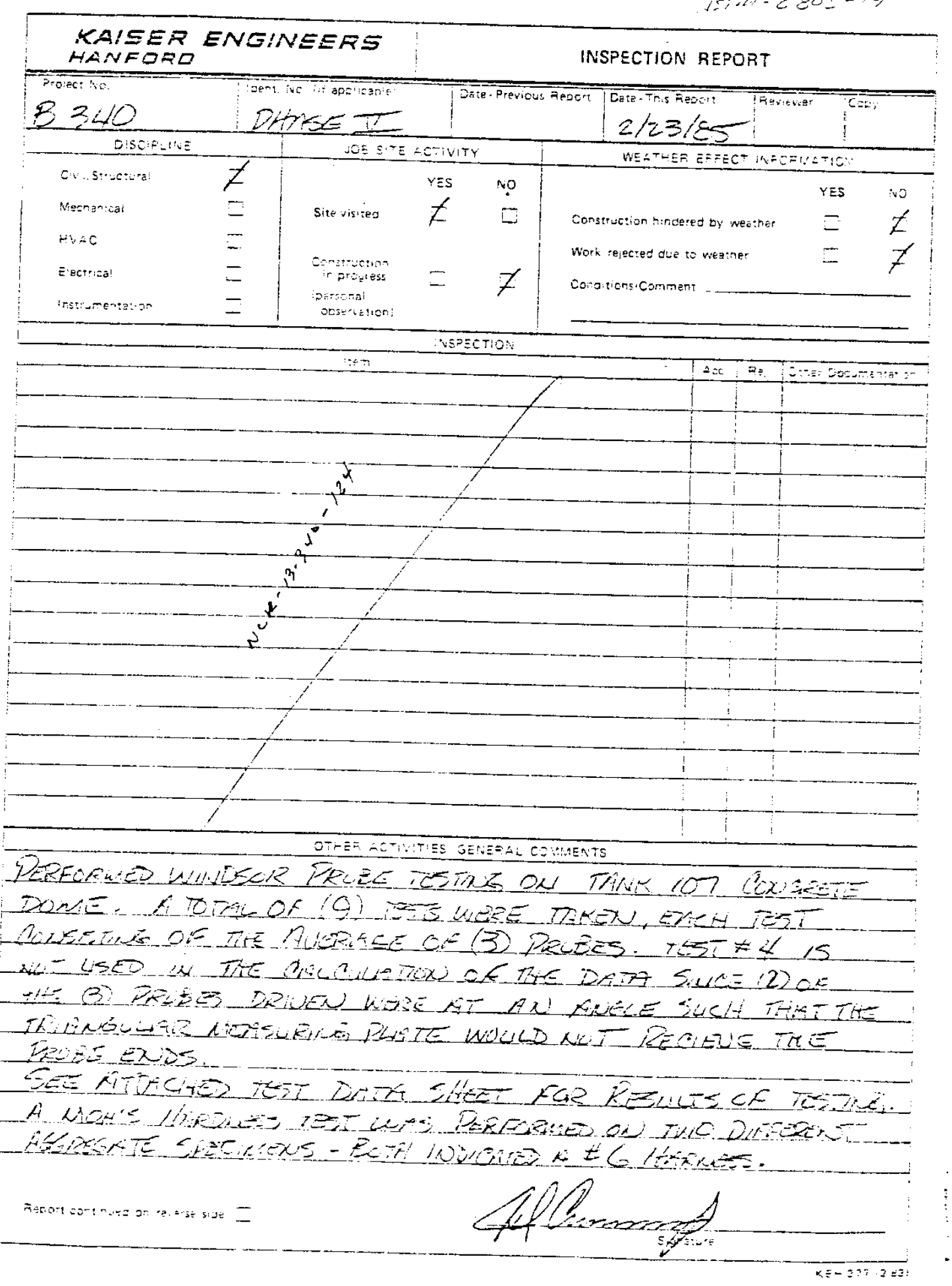


RPP-RPT-55983, Rev. 0

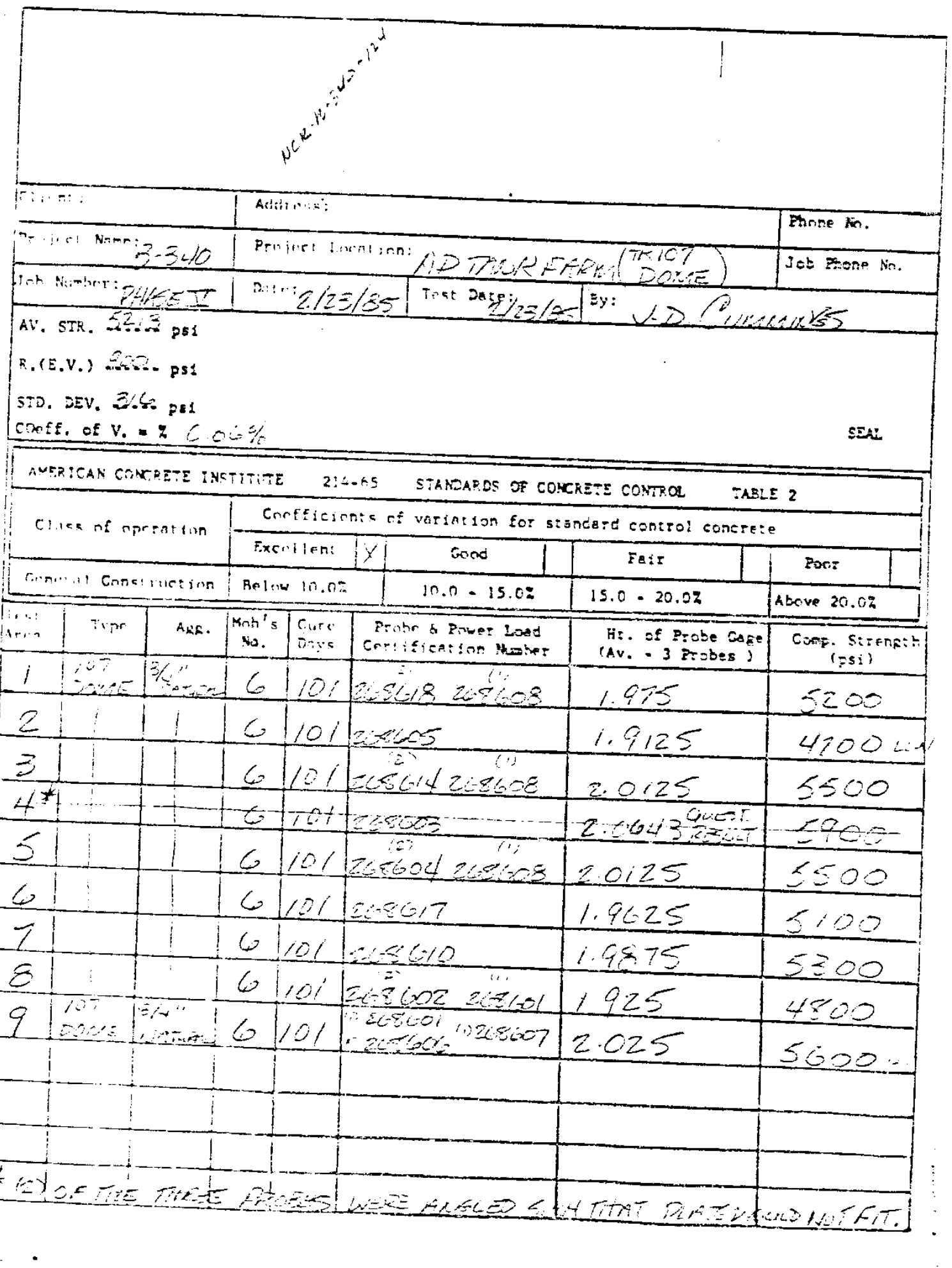


RPP-RPT-55983, Rev. 0

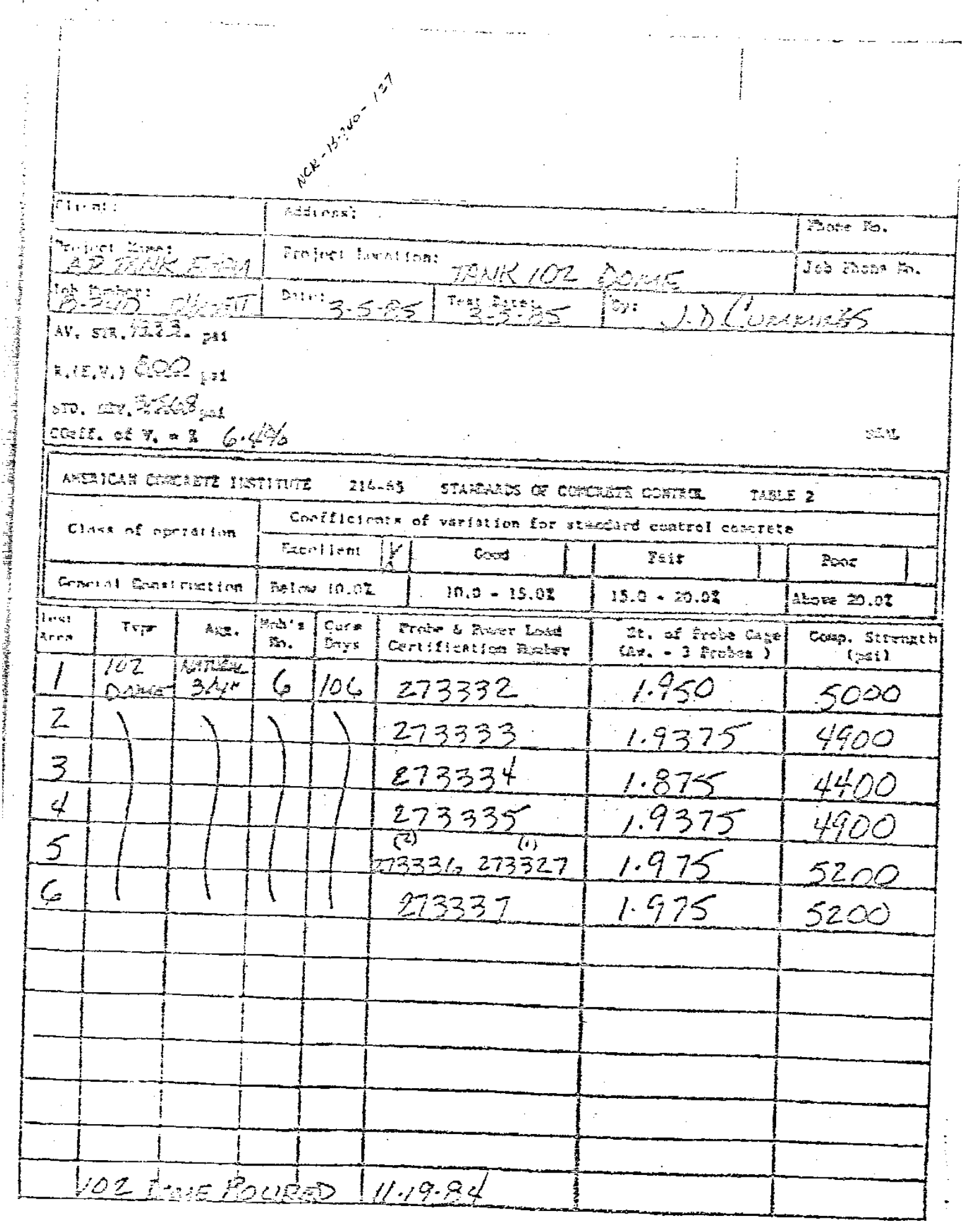


RPP-RPT-55983, Rev. 0

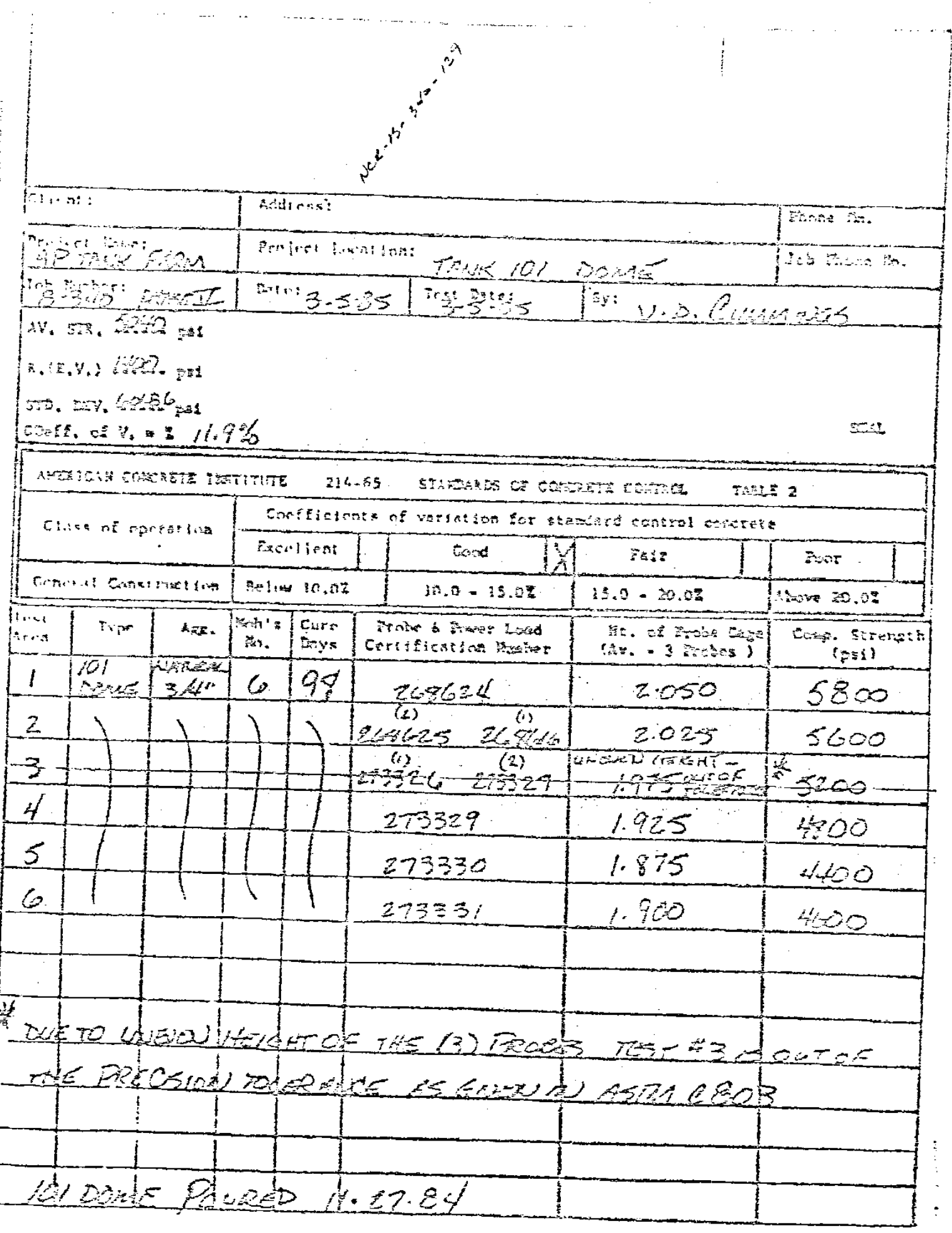


RPP-RPT-55983, Rev. 0

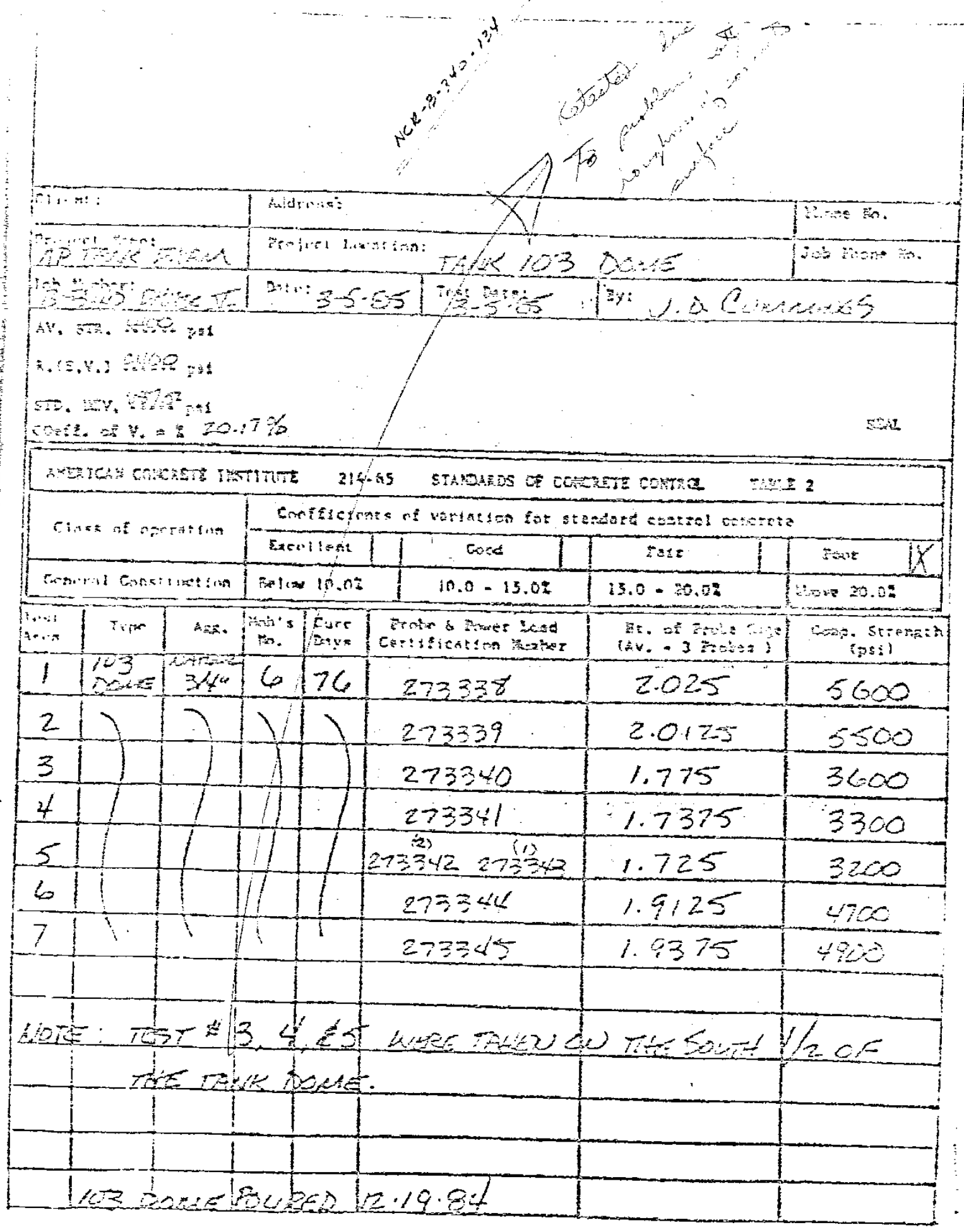


RPP-RPT-55983, Rev. 0

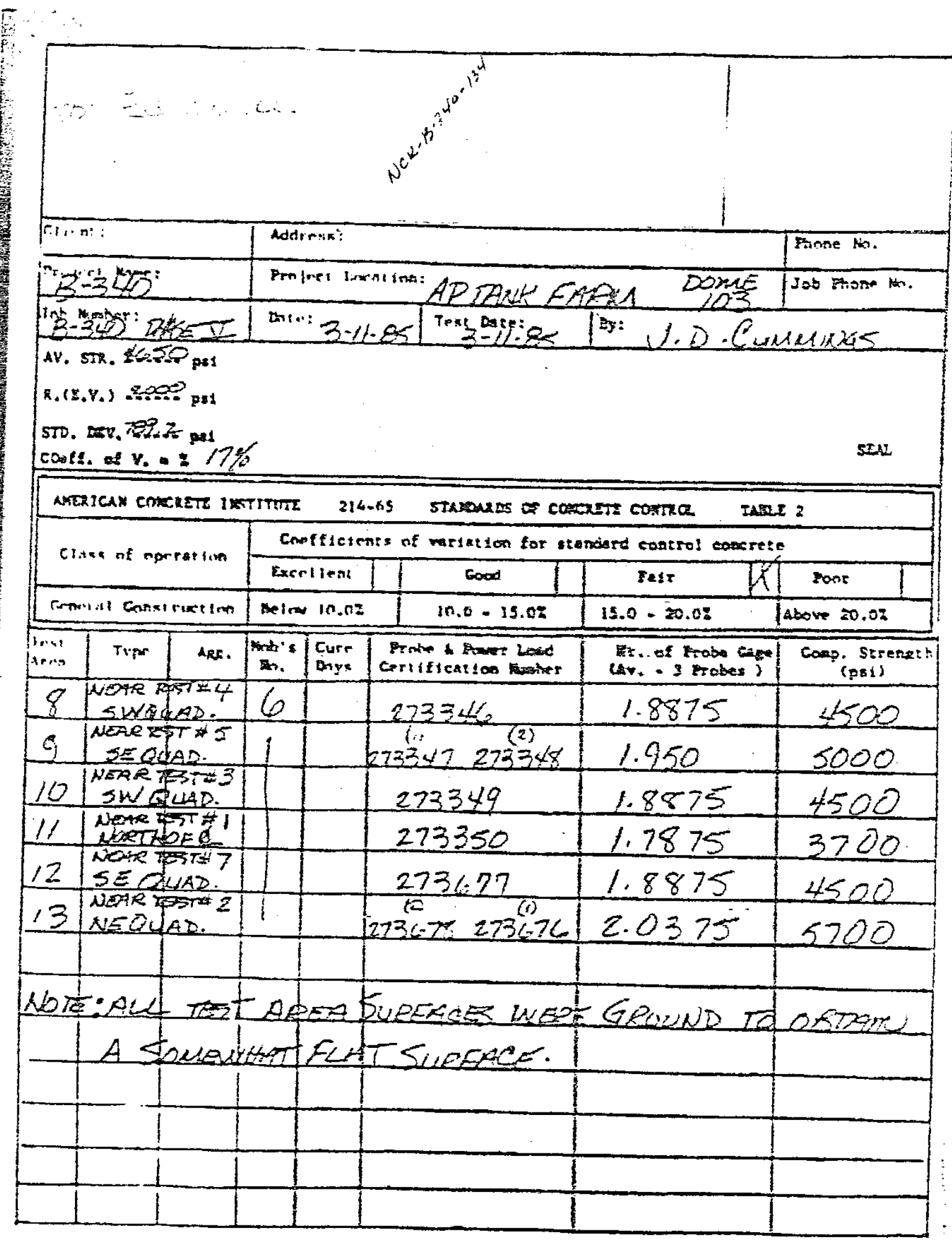

